
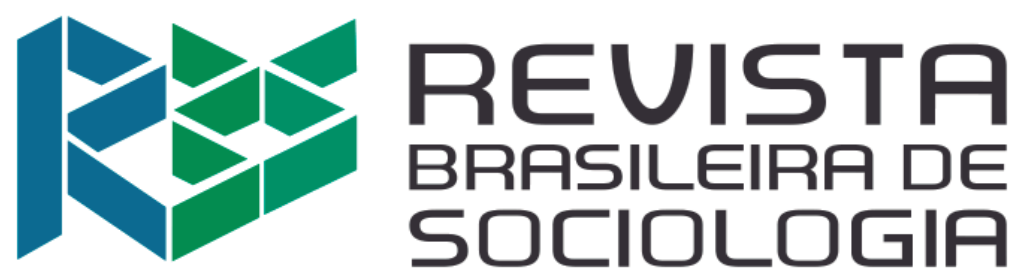

SOCIEDADE BRASILEIRA DE SOCIOLOGIA - SBS

Vol. 06, № 14 | Set/Dez 2018 


\section{SOCIEDADE BRASILEIRA DE SOCIOLOGIA - DIRETORIA (GESTÃO 2017-2019)}

Presidente

Carlos Benedito Martins, UNB

$1^{\circ}$ Vice Presidente

Jacob Carlo Lima, UFSCAR

$2^{\circ}$ Vice Presidente

Edna Maria Ramos de Castro, UFPR

Secretário Geral

Luiz Gustavo da Cunha de Souza, UFSC

\section{Tesoureiro}

Antônio da Silveira Brasil Junior, Unicamp

$1{ }^{\circ}$ Secretário

Helena Maria Bomeny Garchet, UERJ $2^{\circ}$ Secretário

Hermílio Pereira dos Santos Filho, PUCRS

\section{Diretores}

Paulo Roberto Arruda de Menezes, USP

Michel Nicolau Neto, Unicamp

Alex Niche Teixeira, UFRGS

Gabriel Moura Peters, UFPE

Anete Brito Leal Ivo, UFBA

\section{Conselho Fiscal}

Claudio Santiago Dias Junior, UFMG

Andrea Borges Leão, UFCE

Maria Aparecida da Cruz Bridi, UFPR

\section{PUBLICAÇÃO QUADRIMESTRAL DA SOCIEDADE BRASILEIRA DE SOCIOLOGIA - SBS}

\section{Coordenação Editorial}

Carlos Benedito Martins, Universidade de Brasilia

\section{Editores}

Rogerio Proença Leite, Universidade Federal de Sergipe

Sergio Tavolaro, Universidade de Brasilia

\section{Editores Adjuntos}

Adelia Maria Miglievich-Ribeiro, Universidade Federal do Espírito Santo Renan Springer de Freitas, Universidade Federal de Minas Gerais

\section{Comissão Editorial}

Soraya Maria Vargas Cortes, Universidade Federal do Rio Grande do Sul Irlys Barreira, Universidade Federal do Ceará

Celi Scalon, Universidade Federal do Rio de Janeiro

Tom Dwyer, Universidade Estadual de Campinas

\author{
Conselho Editorial \\ Ana Luisa Fayet Sallas, Universidade federal do Paraná \\ Abdelafid Hamouch, Universidade de Lille I \\ André Pereira Botelho, Universidade Federal do Rio de Janeiro \\ Arturo Morato, Universidad de Barcelona \\ Carlos Fortuna, Universidade de Coimbra \\ Cesar Barreira, Universidade Federal do Ceará \\ Charles C. Lemert, Yale University \\ Emil Sobottka, Pontifícia Universidade Católica do Rio Grande do Sul \\ Gabriel Cohn, Universidade de São Paulo \\ Jacob Lima, Universidade Federal de São Carlos \\ José Machado Pais, Instituto de Ciências Sociais da Universidade de Lisboa \\ José Vicente Tavares, Universidade Federal do Rio Grande do Sul \\ José Ricardo Ramalho, Universidade Federal do Rio de Janeiro \\ Lúcio Oliver Costilla, Universidad Nacional Autónoma de México \\ Marcos César Alvarez, Universidade de São Paulo \\ Margaret Archer, EPFL- University of Warvick \\ Maria Stela Grossi, Universidade de Brasília \\ Michel Burawoy, Berkeley University \\ Paulo Neves, Universidade Federal de Sergipe \\ Renato Sérgio de Lima, Fórum Brasileiro de Segurança - FBS \\ Sérgio Adorno, Universidade de São Paulo
}

Revisão:Girllaynne Marques

Diagramação: Adilma Menezes

Capa e web: Allan Veiga Rafael

Ficha Catalográfica elaborada pela UFS

RSB: Revista Brasileira de Sociologia / Sociedade Brasileira de Sociologia - SBS. - Vol. 06, n. 14 (set./dez. 2018)- . - Sergipe: SBS, 2013-

Quadrimestral

ISSN 2317-8507 (impresso)

ISSN 2318-0544 (Eletrônico)

1. Sociologia - Periódicos. I. Sociedade Brasileira de Sociologia

CDU 316(051)

As opiniões, afirmaç̧ões e conceitos emitidos nos artigos publicados na Revista Brasileira de Sociologia são de inteira responsabilidade de seus autores e não expressam posições da RBS ou da Sociedade Brasileira de Sociologia - SBS. 


\section{SUMÁRIO \\ TABLE OF CONTENTS}

Marcos Referenciais Teóricos que têm dado Suporte às Análises dos Movimentos Sociais e ações Coletivas no Brasil - 1970-2018

Theoretical frameworks that support the analysis of social movements and collective actions in Brazil-1970-2018

Maria da Glória Gohn

Inovações Temáticas, “Guinadas” Teóricas e Tradição Intelectual no Brasil

Thematic Innovations, Theoretical "Turn" and Intellectual Tradition in Brazil

Wilson José Ferreira de Oliveira

Fernanda Rios Petrarca

O Ensino de Ciências Sociais na Região Sul: Instituições e Pesquisadores

The Teaching of the Social Sciences in the South region: institutions and researchers

Amurabi Oliveira

Willian Binsfeld

Modernización Productiva y Gestión del Riesgo en la Actividad Industrial Uruguaya

Productive modernization and risk management in the Uruguayan industrial activity

Francisco Pucci

A Indústria 4.0 e o Futuro do Trabalho: Tensões e Perspectivas

Industry 4.0 and the Future of Work: Tensions and Perspectives

Marcelo Augusto Vieira Graglia

Noêmia Lazzareschi

Arquitetura e Urbanismo: Disputas Profissionais e Estratégias de Atuação

Architecture and urbanism: professional disputes and strategies for action

Cristiano Ricardo de Azevedo Pacheco

“Meu Deus! Meu Deus! Está Extinta a Escravidão?”: o Imaginário Político Brasileiro

"My God! My God! Is slavery extinct? ": The Brazilian political imaginary

Glória Diógenes

Paulo Henrique Martins

Encontros entre Paulo Freire e Amílcar Cabral: a Crítica Pós-colonial e Decolonial em Ato

The encounter of Paulo Freire and Amílcar Cabral: the postcolonial and decolonial criticism in act

Adelia Miglievich-Ribeiro

\section{A Trajetória Artístico-intelectual Glauberiana: da Estética da Fome à Eztetyka do Sonho}

The Glauberian artistic-intellectual trajectory: from Aesthetics of Hunger to Eztetyka of the Dream Irma Maria Viana da Silva

242 A Construção de uma Agenda de Investigação Comum em um Oceano de Discordâncias Building a Common Research Agenda in an Ocean of Disagreements

Renan Springer de Freitas

Gustavo de Castro Patricio de Alencar

268 Diretrizes para Submissão de Artigos

Guidelines for submission of articles 



\title{
Marcos Referenciais Teóricos que têm dado Suporte às Análises dos Movimentos Sociais e Ações Coletivas no Brasil - 1970-2018
}

\author{
Maria da Glória Gohn*
}

\section{RESUMO}

O artigo faz um levantamento das abordagens teóricas que têm dado suporte aos estudos sobre os movimentos sociais e as ações coletivas no Brasil ao longo das últimas décadas, mapeando sua diversidade, paradigmas teórico-metodológicos que as fundamentam, categorias e seus autores. Recuperam-se a construção, a transformação e a diversificação destas teorias segundo momentos da conjuntura histórico-política do país, fornecendo elementos para avaliar sua adequação à realidade brasileira. Como resultado, apresentamos cinco blocos de teorias - neomarxistas, culturalistas ou identitárias, institucionalistas, autonomistas e neoliberais. Elas têm influenciado, informado e orientado a produção brasileira sobre os movimentos sociais ao longo de cinco ciclos histórico-políticos distintos: $1^{\circ}$ - na década de 1970; $2^{\circ}$ - transição democrática dos anos de 1980; $3^{\circ}$ pós-Constituição de 1988; $4^{\circ}$ - na década de 2000; e $5^{\circ}$ - pós-junho de 2013.

Palavras-chave: Movimentos Sociais. Ações Coletivas. Abordagens Teóricas.

* Professora Titular da Faculdade de Educação UNICAMP. Professora Visitante Sênior da UFABC. Pesquisadora 1 A CNPq. 


\begin{abstract}
THEORETICAL FRAMEWORKS THAT SUPPORT THE ANALYSIS OF SOCIAL MOVEMENTS AND COLLECTIVE ACTIONS IN BRAZIL-1970-2018
\end{abstract}

The article surveys the theoretical approaches that have supported the studies on social movements and collective actions in Brazil over the last decades, mapping their diversity, theoretical-methodological paradigms that substantiate them, categories and their authors. The construction, transformation and diversification of these theories are recovered according to moments of the historical-political conjuncture of the country, providing elements to assess their adequacy to the Brazilian reality. As a result, we present five blocks of theories-neomarxists, culturalists or Identitaries, institutionalists, autonomists and neoliberals. They have influenced, informed and oriented the Brazilian production about social movements over five different historical-political cycles: 1st- in the decade of 1970; 2nd- democratic transition of 1980 years; 3rd- post Constitution of 1988; 4th- Decade of 2000; and 5th- Post June of 2013.

Keywords: Social movements. Collective actions. Theoretical approaches.

\title{
Apresentação
}

Este artigo objetiva fazer um levantamento das abordagens teóricas que têm dado suporte aos estudos sobre os movimentos sociais e as ações coletivas, produzidos no Brasil nas últimas cinco décadas, focalizando eixos temáticos tratados e os referenciais teóricos utilizados. Embora já existam textos chamando à atenção para este tema e seu debate (KOWARICK, 1987; ALONSO, 2009, entre outros), uma análise sobre as abordagens utilizadas na produção acadêmica e sua transformação ao longo do tempo se faz necessária dada a diversidade de teorias existentes. Não iremos mapear e nem analisar a produção brasileira em si, tarefa importante, mas impossível de ser tratada em um só artigo, em conjunto com o problema ora posto em tela - os quadros referenciais teóricos que têm dado suporte aos estudos e publicações sobre os movimentos sociais no Brasil. Apenas citaremos alguns desses estudos ou seus autores como exemplos das abordagens, sem mapear toda a produção, que é vasta, no período histórico tratado.

O interesse deste artigo decorre, em primeiro lugar, da necessidade de se realizar um balanço entre as teorias que têm sido utilizadas e sua adequação 
à realidade do país. Disso resulta uma primeira questão: há correlação entre teoria e realidade ou há um deslocamento entre estes dois campos? Uma segunda razão pelo interesse é a busca de entendimento da relação entre teorias e a conjuntura política do país, no momento em que as análises são realizadas. Aqui resulta outra indagação: Existe uma relação ou associação das teorias com os processos históricos vivenciados na conjuntura política do país? Desta questão formulamos uma hipótese: a utilização de certas teorias, em dado tempo histórico, tem íntima correlação com a conjuntura social, política e econômica do país, dada a existência de ciclos específicos de lutas, movimentos, protestos e mobilizações, ou de práticas de cooperação e participação em políticas institucionalizadas nos mesmos ciclos. No período histórico brasileiro tratado neste artigo, detectaram-se cinco ciclos políticos distintos, e a respectiva participação de segmentos da sociedade civil em movimentos e/ou ações coletivas a saber: $1^{\circ}$ - na década de 1970; $2^{\circ}$ - transição democrática dos anos de 1980; $3^{\circ}$ - após Constituição de 1988; e $4^{\circ}$ - na primeira década do novo século, e 5º após junho de 2013.

As teorias analisadas foram aglutinadas em cinco blocos segundo os pressupostos teórico-metodológicos e o os paradigmas em que se localizam e serão explicitadas ao longo do texto. Elas são: teorias neomarxistas, teorias culturalistas ou identitárias, teorias institucionalistas, teorias autonomistas e teorias neoliberais. É importante destacar que utilizamos a categoria 'ciclo' como um processo histórico-político peculiar e distinto, composto por um conjunto de demandas, reivindicações, manifestações, protestos, contestações, ou de ações coletivas de cooperação e parceria de organizações civis, ou de instituições participativas públicas atuando em políticas públicas, ocorridas em dado tempo histórico. Portanto, um ciclo se configura a partir das especificidades da conjuntura político-social do país e dos atores em cena. Os ciclos são períodos possíveis de serem datados em que se observam novos repertórios das formas de ação coletiva, novas formas de práticas e performances de contestação, ou novas formas da colaboração/inclusão dos atores sociais. Usualmente os ciclos, especialmente os de protesto, produzem narrativas com símbolos e significados novos à questão em tela. As práticas e os discursos de um ciclo criam enquadramentos de significados, apoiados em conjuntos de valores, visões de mundo e ideologias específicas (Vide TILLY; TARROW; McADAM, 2001). Em cada ciclo analisado neste artigo, destacam-se os termos do debate predominante entre os analistas, as 
teorias e os paradigmas teóricos que alicerçam essas teorias, naquele período histórico. Um ciclo abrange também as análises sobre as categorias básicas nomeadas para construir as abordagens teóricas. Há, portanto, uma historicidade no uso das categorias em um dado ciclo.

A hipótese acima enunciada foi testada após as análises ao longo deste artigo e levou-nos a dadas conclusões que antecipo, agora, para maior atenção do leitor aos diferentes ciclos que iremos abordar, a saber: em épocas de regime político fechado, no primeiro ciclo, da resistência ao regime militar, na década de 1970 e início dos 80, as teorias críticas advindas do campo marxista tiveram campo maior de desenvolvimento. Em períodos de recrudescimento da luta pela redemocratização, especialmente entre 1982-1988, as teorias culturalistas identitárias proliferam mais rapidamente. Após 1988, com a nova Constituição, as teorias 'institucionalistas' dominaram a cena. Em períodos de crise econômica e crise política, após junho de 2013, as teorias críticas, libertárias ou autonomistas têm tido presença maior.

Nossa fonte dos dados é ampla. Advém de material de estudos e pesquisas que realizo desde 1970 sobre o tema dos movimentos sociais. Isso implica a consulta bibliográfica a uma vasta biblioteca de livros e artigos, nacionais e internacionais, organizada ao longo de mais de quatro décadas, incluindo papers apresentados na ANPOCS e na SBS. O fato de eu ter coordenado Grupos de Trabalho (GTs) na ANPOCS e na SBS, várias vezes, sobre o campo temático dos movimentos sociais ofereceu-me também a oportunidade de observar e registrar os estudos e autores na área. Este artigo traz ainda uma síntese de pontos básicos de dois livros que publiquei anteriormente sobre as teorias dos movimentos sociais (GOHN, 2017b; GOHN, 2014b), assim como incorpora pesquisa recente feita em acervos de textos online, de revistas nacionais e internacionais, sobre os movimentos na atualidade.

\section{Primeiro Ciclo - Década de 1970 - Resistência contra regime militar e as teorias que influenciaram a produção acadêmica brasileira sobre os Movimentos Sociais}

No Brasil, a partir da década de 1970, inicia-se um novo ciclo de lutas sociais, de resistência ao regime militar, numa conjuntura de forte controle social, vigência do Ato Institucional $n^{0} 5$, prisão e perseguição a todos que se opunham ao regime político a partir de 1964. Esta resistência se intensifica 
na segunda metade da década de 70, buscando brechas para a restauração da democracia. Movimentos pela Anistia a exilados e presos políticos, movimentos advindos das Comunidades Eclesiais de Base, movimentos do novo sindicalismo do ABC paulista e outras regiões, movimentos populares de mulheres em bairros da periferia por creches, ou de moradores por transportes coletivos, ou por postos de saúde, tudo isso criou o contexto de um novo ciclo de lutas na sociedade brasileira, o primeiro mapeado neste artigo (GOHN, 2017 c). A produção acadêmica brasileira sobre os movimentos sociais, deste período, caracterizou-se por quatro pontos: primeiro - uma grande vitalidade de estudos de natureza mais empírico-descritiva, centrados em movimentos populares, especialmente de bairros periféricos, analisados a partir das falas dos agentes. A pesquisa participante, ou militante, e os estudos de caso foram a opção metodológica predominante. Embora pouco analíticos, eles contribuíram, no campo das Ciências Sociais, para seu dinamismo e renovação, dando subsídios empíricos para um retrato das carências e demandas das camadas populares e contribuindo para uma Sociologia dos Movimentos Sociais. Segundo ponto - a localização da maioria destes estudos em programas de Pós-Graduação, fruto da expansão do ensino superior na época e das reestruturações no sistema de Pós-Graduação no país, especialmente nas universidades públicas e algumas confessionais, como as PUCs. Este fato ocorreu também em outros países da América Latina em que programas de Pós-Graduação estavam implantados, como no Chile, Argentina e México. As inúmeras dissertações e teses elaboradas pelos programas de Pós-Graduação, área de Sociologia, na USP e Unicamp, ao final da década de 1970 e primeiros anos de 1980, exemplificam esta afirmação. Observa-se uma divisão dos estudos nas suas áreas acadêmicas, predominando a produção sobre movimentos sociais em programas de Sociologia (KAUCHAKJE, 1997), e a concentração de trabalhos apresentados em GTs da ANPOCS - Associação Nacional de Pesquisa e Pós-Graduação em Ciências Sociais - e da SBS - Sociedade Brasileira de Sociologia. A ANPOCS criou, na sua fundação, em 1976, um GT específico sobre Movimentos Sociais. Com isso, ocorre a constituição de espaços e campos de pesquisa abertos à temática, possibilitando a formação de grupos de pesquisa e debates sobre movimentos e ações coletivas.

O terceiro ponto a destacar é o predomínio da abordagem teórica decorrente de leituras renovadas das teorias marxistas, especialmente advindas 
de abordagens gramiscianas; os estudos desenvolveram análises estruturais destacando o papel dos conflitos e contradições urbanas, ditas como secundárias no desenvolvimento urbano do país, a exemplo da produção de Manuel Castells (1974) e Jordi Borja (1975) nos anos de 1970. Eric Hobsbawn (1970) também foi fonte de inspiração, nos marcos da teoria marxista não ortodoxa, especialmente devido ao destaque que o autor dá à área da cultura, possibilitando captar o dia a dia, o cotidiano popular. Na mesma linha temos E.P. Thompson (2004). O quarto ponto deste ciclo foi a predominância de estudos sobre os movimentos populares urbanos, especialmente advindos de áreas periféricas ou enclaves de favelas nas cidades grandes, embora também se registrem, no período, alguns estudos sobre outros movimentos, de afrodescendentes, mulheres etc. Estes últimos irão predominar nas décadas de 1980-1990, em relação ao número de estudos sobre os movimentos populares. As categorias povo, classes populares, periferia urbana, contradições urbanas entre outras pautaram os debates e artigos foram escritos para diferenciar classes populares e classe operária etc. O foco estava nas reivindicações advindas do local de moradia, num contexto de expansão desordenada das cidades, loteamentos clandestinos na periferia, falta de transporte, creches etc. E o país estava vivendo o 'milagre brasileiro' com expansão das camadas médias, expansão do ensino superior, ampliação do mercado de trabalho, com as mulheres das camadas médias deixando de ser apenas 'dona de casa', saindo para trabalhar ou estudar, e tendo de contratar 'empregadas domésticas' - termo usual na época -, aquelas que não encontravam creches para os filhos onde moravam. A expansão da moradia vertical dos bairros tradicionais das camadas médias levou à absorção de grande contingente de trabalhadores na construção civil, que moravam na periferia. Portanto, a conjuntura econômica e política da época favorecia as análises do campo estrutural.

A influência do paradigma marxista na incipiente produção brasileira sobre os recém-criados movimentos na época explica-se, pois, em parte, pelo contexto político do país: com o regime militar, intelectuais e setores sociais mais engajados se unem e buscam alternativas para a volta da democracia, alguns sindicatos se reestruturam, e surgem movimentos sociais ao redor de pastorais ou de apoio as greves operárias etc. E. Sader (1988) é o autor que fez a melhor análise das interações entre os 'novos atores' deste período; registre-se que ele os analisou não sob a ótica marxista, mas segundo 
elementos das teorias autonomistas, sendo, portanto, um 'madrugador' da proliferação desta abordagem, mais de trinta anos antes de ela ganhar força nas análises, na década de 2010.

\section{Segundo Ciclo - Transição para a Redemocratização até a Constituição de 1988}

O segundo ciclo de movimentos no Brasil, tanto do ponto de vista das práticas efetivas como da produção acadêmica, ocorre a partir de 1980 no período de transição para a democracia, com as alterações na conjuntura política e o retorno de eleições para governos estaduais. Ocorre o surgimento de inúmeros movimentos de gênero, de afrodescendentes, centrais de sindicatos e movimentos sociais, movimentos no campo etc., a exemplo da construção da ANAMPOS (Associação Nacional Movimentos Populares), CONAM (Central Nacional de Movimentos Populares), CUT (Central Única dos Trabalhadores), a criação do MST (Movimento dos Trabalhadores Sem Terra), a luta pelas Diretas Já em 1984, a fase da Constituinte de 1985-1988 etc.

O segundo ciclo trouxe, inicialmente, um outro eixo paradigmático de apoio às abordagens teóricas sobre os movimentos sociais - o eixo culturalista identitário. Ele pode ser observado nos estudos sobre os novos movimentos sociais, focados no eixo das identidades, com a utilização de abordagens desenvolvidas por Alberto Melucci (1976; 1980), Alain Touraine $(1965 ; 1973 ; 1977 ; 1978 ; 1984 ; 1989 ; 1994)$, Claus Offe $(1983 ; 1985$; 1988); Habermas (1981) e outros. A abordagem das identidades (atribuídas ou adquiridas) destaca aspectos da cultura advindos de diferentes tipos de pertencimentos, tais como: a um dado território, grupo étnico, religião, faixa etária, comunidade ou grupo de interesses etc. Os vínculos criados e as ações desenvolvidas são frutos de processos de reflexividade - os sujeitos participantes constroem sentidos e significados para suas ações a partir do próprio agir coletivo. A ação dos sujeitos é relevante. No Brasil, a influência maior desta corrente nos estudos sobre os movimentos foi, inicialmente, a obra de A. Touraine $(1977 ; 1985 ; 1989)$ e, posteriormente, os textos de A. Melucci $(1989 ; 1996)$, e, nos anos de 1990, destacam-se Arato e Coehn (1992), com as discussões sobre a sociedade civil, a partir de J. Habermas (1981). Na Teoria da Ação Comunicativa (1985), Habermas identifica os novos movimentos sociais com a resistência defensiva aos processos de ex- 
tensão da racionalidade técnica dentro de todas as esferas da vida social; e diz ainda que, ao mesmo tempo, eles demandam alto nível de justificativa racional na esfera moral e cultural. Para o Habermas, os novos problemas sociais têm a ver com qualidade de vida, igualdade de direitos, autorrealização individual, participação e direitos humanos. Contrastando com a velha política dos trabalhadores, a nova política originada nos novos movimentos sociais advém basicamente da nova classe média, da geração dos jovens e dos grupos sociais com mais alto grau educacional. Os novos movimentos estão localizados na esfera sociocultural e a ênfase de suas atividades é sobre temas como: motivações, moralidade e legitimação. Estas análises, feitas no cenário europeu dos anos 1960-1980, contrasta com o cenário brasileiro de movimentos predominantemente populares nos anos de 1970-1980. Talvez isso explique porque Habermas foi 'redescoberto' ou teve uma aplicação maior nos estudos sobre os movimentos sociais, no Brasil, só na década de 1990, quando aqui, na realidade brasileira, predominavam os 'novos movimentos sociais' (gênero, afrodescendentes, ambientalistas etc.), os quais de fato emergiam mais de camadas médias da população, e não como nos anos de 1970-80, quando eram os movimentos populares os atores principais em cena na sociedade civil.

No Brasil, movimentos sociais dos sem-terra e dos sem-teto (moradia), de povos indígenas, quilombolas, moradores de áreas de barragens, além das ONGs, da economia solidária etc. predominaram nos estudos no campo analítico apoiado nas correntes teóricas dos novos movimentos sociais identitários, abarcando também redes de movimentos (SADER, 1988; SCHERER-WARREN, 1993; GOHN, 1982; 1985; 1991; 1995; DOIMO, 1984; 1995; entre outros.). Os estudos sobre os movimentos populares urbanos continuaram na década de 80, que foi caracterizada posteriormente como 'movimentalista'. A ampliação dos atores em cena e os novos referenciais teóricos levaram ao brilhante texto de Machado da Silva e Torres Ribeiro (1985) quando indagavam: "Por onde andam nossas ideias?".

\section{Terceiro Ciclo - 1988 - A construção de Instrumentos Par- ticipativos Institucionalizados}

O terceiro ciclo participativo ocorre após a aprovação da nova Constituição, em 1988, quando o foco de muitas investigações se desloca do mo- 
vimento dos atores da sociedade civil para a atuação de múltiplos atores nas políticas públicas e para a construção de novos canais de participação institucionalizados, previstos na nova Constituição. A conjuntura política brasileira oferece-nos, portanto, elementos para entendermos a adesão dos pesquisadores às teorias institucionalistas, pois, até então, os movimentos mais representativos estavam organizados no seio da própria sociedade civil.

No terceiro ciclo, um novo eixo paradigmático de suporte teórico às pesquisas sobre os movimentos e ações coletivas cresce e se fortalece pós 1988: o das abordagens das teorias 'institucionalistas', ou Teoria da Mobilização Política (TMP). Até então essa abordagem era pouco utilizada, destacando-se estudos de Boschi (1987) e Cardoso (1985). A TMP foi desenvolvida por McAdam (1982), Tilly (1978; 1983; 1986;1993; 1994; 1995), Tarrow (1994) entre outros. As teorias TMP focalizam processos de mobilização e de institucionalização das ações coletivas. Os vínculos e redes de sociabilidade são importantes para observar o desempenho das pessoas em instituições, organizações, espaços segregados, associações etc., visando analisar como elas se mobilizam, que recursos utilizam, que oportunidades políticas e institucionais aproveitam ou desenvolvem, que repertórios constroem a partir de demandas e como confrontam-se com os diferentes agentes da cena pública, especialmente com os poderes públicos. O paradigma teórico que embasa toda a elaboração, construção e desenvolvimento desta abordagem advém de heranças das teorias da privação social, desenvolvidas, inicialmente, pelos interacionistas simbólicos no início do século XX. A teoria da Mobilização de Recursos formulada por Olson (1965) na década de 1960, com viés bastante economicista, também deu elementos para a construção do paradigma institucionalista. O debate nos Estados Unidos nos anos de 1970-1980 trouxe outros aportes teóricos, que deslocaram o foco dos recursos disponíveis para a importância da mobilização política, focalizando processos institucionais e as estruturas de oportunidades políticas - utilizadas pelos diferentes atores e organizações sociais na configuração do campo político e administrativo em que atuam. Construiu-se a Teoria da Mobilização Política (TMP). Os autores referenciais desta abordagem teórica passaram a ser McAdam (1994), McAdam, McCarthy e Zald (1996), Tarrow (1994; 2005), Tarrow e Della Porta (2005), Meyer e Minkoff (2004), Charles Tilly (1978; 1995; 2007) e Tilly e Tarrow (2006). Observa-se neste bloco analítico o destaque para Charles Tilly, que, juntamente com McAdam e Tarrow, reformularou a TMP a partir 
dos anos de 1990, a qual passou a denominar-se teoria do "contentious politics”, Teoria do Confronto Político - TCP. As práticas civis de protesto foram incorporadas à análise dos processos de mobilização política em que se confrontam atores de movimentos e organizações, atores políticos dos governos constituídos etc. Nessa teoria, os movimentos criam repertórios de ação coletivas, as quais, dependendo do contexto e do regime político vigente, podem ser prescritas, toleradas ou proibidas (TILLY, 2006). Esta abordagem difundiu-se nos Estados Unidos e na Inglaterra desde os anos de 1990, chegando mais tardiamente à América Latina, especialmente na Argentina e no Brasil, onde passou a ser utilizada para análise das relações dos movimentos com o estado, participando em políticas públicas, via estruturas institucionais como os conselhos, câmaras ou outros na esfera pública. Na primeira década de 2000, essa abordagem teve hegemonia no Brasil sobre as outras citadas acima, porque o destaque na cena pública passou para a questão da participação institucionalizada, a ser tratada adiante.

Bert Klanderman (1984) afirma que não há incompatibilidade entre essa abordagem e a anterior, das culturas identitárias, observando que a grande diferença entre as duas é mais os lócus da ação dos sujeitos. Os primeiros destacam a sociedade civil e o segundo a sociedade política, o espaço das ações institucionalizadas ao redor do estado e das políticas públicas. Vale a pena observar cada uma dessas abordagens, pois a utilização de uma ou outra é dada não apenas por escolhas metodológicas, mas se podem diferenciar correntes e pesquisadores que destacam as ações autônomas e culturais e os adeptos das ações que giram ao redor de políticas institucionais ou confrontam o estado. Os pontos de divergência que separam as duas abordagens referem-se às questões: como se dá o processo de mudança social e qual o papel da sociedade civil e do estado no processo de desenvolvimento de um país. Assim, teorias marxistas, teorias críticas, culturalistas ou identitárias e as teorias institucionalistas têm rios e oceanos de divergências.

Os estudos apoiados nas correntes marxistas decrescem na produção brasileira sobre os movimentos sociais após 1990, ficando mais localizados nos estudos sobre sindicatos de trabalhadores, urbanos e rural, e entre alguns analistas do Movimento dos Trabalhadores Sem Terra próprio - MST- criado nos anos de 1980 e que cresceu na cena pública a partir dos anos 90 (CALDART, 1997). Ao longo dos anos de 1990, debateu-se muito nos congressos se os movimentos populares urbanos estavam em crise. Ao final dos anos 90, 
as ONGs crescem e ganham os holofotes das ações coletivas civis, estimuladas por leis, como a chamada Lei do Voluntariado de 1999.

Observa-se no conjunto do terceiro ciclo a utilização teórica de paradigmas referenciais de análise construídos em realidades diversas daquelas em que os movimentos ocorriam de fato. Abordagens europeias culturalistas que analisaram os movimentos feministas, ambientalistas, pacifistas etc., desde a década de 1960, e abordagens institucionalistas norte-americanas, que focalizaram os movimentos de direitos civis nos Estados Unidos, desde a década de 1950, ou os movimentos históricos europeus, foram a base, em suas várias vertentes, para a análise dos dados da realidade no Brasil (ver DAGNINO; ALVAREZ; ESCOBAR, 2000). Resulta que, neste cenário, as posturas metodológicas de análise dos movimentos sociais no Brasil foram híbridas, geraram muitas informações, mas grande parte do conhecimento produzido foi orientado inicialmente por teorias criadas em outros contextos, diferentes da nossa realidade nacional. Os sujeitos das ações coletivas e suas histórias eram muito diferentes.

\section{Quarto Ciclo - Transformações no Novo Século}

Ao final dos anos 90, o movimento antiglobalização entra na pauta dos movimentos internacionais e na década de 2010 muda o foco dos sujeitos relevantes nas ações coletivas, como veremos abaixo. No Brasil, o reflexo será sentido nas edições do Fórum Social Mundial. Portanto, o quarto ciclo tem como marca uma forte articulação dos movimentos sociais no plano internacional. Movimentos de luta pela terra criam redes como a Via Campesina. Movimentos pela moradia relacionam-se com Fóruns Internacionais do Habitat etc.

Na primeira década do novo século, com a ascensão de grupos da oposição ao poder político da nação, na representação do Partido dos Trabalhadores, em diferentes esferas de governo (federal, estadual e municipal) deslocou -se a ênfase dos debates sobre a participação popular dos agentes da sociedade civil (movimentos, ONGs, coletivos, associações e outros) para a temática da participação social em esferas institucionais públicas. Registre-se ainda que vários militantes de movimentos e associações entraram na estrutura estatal, como representantes nos conselhos, fóruns, ouvidorias etc. ou mesmo como funcionários ou assessores contratados. $\mathrm{O}$ "ativismo insti- 
tucional” (ABERS, 2016) resultante passou a buscar referenciais teóricos nas abordagens que lançavam olhares para as instituições e estruturas de poder. Como foi enunciado acima, a Teoria do Confronto Político de Tilly, McAdam e Tarrow; a teoria do reconhecimento de Honneth, (2003) e Fraser (2001), assim como a denominada abordagem relacional (DIANI; McADAM, 2003) passaram a ser as grandes referências dos analistas sobre a participação social em estruturas institucionalizadas.

O associativismo civil advindo da participação de representantes da população em estruturas institucionalizadas estatais, dadas por conselhos, câmaras e grandes conferências nacionais, tem sido tratado na produção brasileira mais sob o foco das análises das ações coletivas e teorias da participação e menos como movimentos sociais. Este associativismo civil com apoio institucional nas diferentes conferências temáticas (mulheres, juventude, afrodescendentes, ou áreas temáticas como educação, alimentação etc.) produziu uma literatura relativamente vasta e recente no Brasil, tratando do tema da participação social em esferas institucionais. Registro apenas três publicações relevantes que podem contribuir aos leitores deste artigo, a exemplo de Milani (2008), Carlos, Dowbor e Albuquerque (2017), Almeida, Cayres e Tatagiba (2015). Entretanto, nos anos de 2000, não se teve a participação apenas nas instâncias institucionalizadas. Os movimentos clássicos, como MST, MTST, os sindicatos etc., continuaram com ações, mais pela via de negociações do que pela dos protestos nas ruas; os novos movimentos sociais, das mulheres, afro, índios etc., também continuaram e tiveram avanços significativos em leis, tais como Lei Maria da Penha, demarcação de terras de ancestrais etc. (vide Gohn, 2013). No movimento pela moradia, tiveram-se também várias conquistas, como o Estatuto da Cidade. No movimento dos estudantes, passam a ocorrer renovações e criam-se grupos novos, que pautaram causas da educação de forma renovada, como as tarifas do transporte. O Movimento Passe Livre-MPL, surgido em 2003, retoma utopias, como o passe gratuito, e protagoniza as revoltas da catraca, em Florianópolis e em Salvador. Ele passa a ser mais conhecido no FSM de 2005 em Porto Alegre. Como se sabe, o MPL terá papel decisivo em 2013. No quarto ciclo, ocorreram ocupações em universidades públicas em ações diferenciadas das usuais greves de estudantes, funcionários ou docentes.

Portanto, as mudanças não foram apenas na forma de produzir o conhecimento. As mudanças básicas vieram de transformações da própria realidade 
sociopolítica, que passaram a exigir leituras teóricas renovadas, novos aportes foram mobilizados ou ressignificados. Ocorre, pois, uma repolitização dos movimentos sociais a partir do final da década de 2000 sob novos paradigmas inspiradores das ações coletivas, muitos deles construídos a partir de ideias e utopias já bem antigas, como demonstraremos no $5^{\circ}$ ciclo, a ser tratado abaixo, ao analisarmos a influência das abordagens advindas do socialismo libertário, do anarquismo, com os autonomistas e outros, porém totalmente renovados sob a égide da sociedade contemporânea com seus problemas, desafios, recursos comunicacionais e tecnológicos, aliados a uma descrença da sociedade na política e nos políticos dadas as práticas de corrupção existentes. Mas esta renovação não implicou ruptura ou negação do passado, ao contrário. A nova etapa das lutas sociais do século XXI se faz aliando inovações tecnológicas e retorno às teorias do século XIX, totalmente revisadas, para a análise dos movimentos sociais. De um lado, os neomarxistas em análises apontam os efeitos destrutivos da globalização econômica sobre o mercado de trabalho, tais como a desestruturação das carreiras, o desemprego etc. que dão base para movimentos de protestos, num contexto de sindicatos enfraquecidos (LINERA, 2009; HARVEY, 2011; ZIZEK, 2011; 2012). De outro, ressurge o socialismo libertário, as feministas no leque dos 'novos movimentos', destacando-se, entre outras análises, aquelas realizadas por Judith Butler (1993) nos estudos sobre gênero; e desponta o humanismo holístico (HESSEL, 2011), em certos segmentos dos estudos sobre povos indígenas da realidade latino-americana como a teoria do 'bien vivir'. A abordagem da descolonização (QUIJANO, 2005; TAPIA, 2009; MIGNOLO, 2003; entre outros), antes restrita aos países latino-americanos de língua espanhola, ganha destaque no Brasil na primeira década do século XXI. Sabe-se que ela teve sua elaboração inicial na Europa em relação ao tema da colonização, especialmente em estudos sobre a África e as formas coloniais ainda lá existentes (ver SPIVAK, 2008). Embora mais ampla, pois não é uma teoria específica sobre movimentos sociais, as várias abordagens da teoria neo ou decolonial transformaram-se em eixo central de pesquisas e de várias frentes de produção intelectual que conferem especificidade à América Latina, especialmente na temática da luta dos povos indígenas (ver QUIJANO, 2005; 2004). Sirvent (2008), adepta dessa abordagem, preconiza a necessidade de se construir poder por meio do conhecimento e isto implica “construir categorias para pensar a realidade que possam gerar ações de mo- 
bilização coletiva em confrontação com os significados que desmobilizam e paralisam” (SIRVENT, 2008, p. 22). Na América Latina, o CLACSO - Conselho Latino Americano de Ciências Sociais - é um grande incentivador das abordagens neocoloniais. No Brasil, essa abordagem influenciará decisivamente o debate Sul-Sul, já no novo século. Nele, se discute a colonialidade na produção do saber afirmando-se que as teorias elaboradas no hemisfério Norte, composto de maioria branca e de países desenvolvidos, têm predominado nas análises das ciências sociais e outras áreas do conhecimento, influenciando as análises e as políticas públicas.

Na década de 2000, portanto, no plano das análises, não se tratava mais de contrapor os novos movimentos sociais - nucleados em torno de questões identitárias, tais como sexo, etnia, raça, faixa etária etc. -, aos "velhos" movimentos, dos trabalhadores, como Claus Offe (1988) e outros fizeram na década de 1980, por exemplo. Não se tratava, portanto, de contrapor tipos de movimentos ou ações coletivas e nem paradigmas teóricos interpretativos como mais ou menos adequados, até porque todos eles continuam a coexistir com os novos. Tratava-se de reconhecer a diversidade de movimentos e ações civis coletivas, suas articulações e os marcos interpretativos que têm lhes atribuído sentidos e significados novos, o que eles têm trazido à luz no campo da investigação de uma Sociologia dos Movimentos Sociais. Resulta do novo cenário que movimentos sociais voltaram a ter visibilidade e centralidade a partir da primeira década do século XXI, como atores que pressionaram por processos de mudança social e reinventaram as formas de fazer política. Eles também se transformaram bastante, realizaram deslocamentos em suas identidades e incorporaram outras dimensões do pensar e agir social. Alteram seus projetos políticos. Mas como são muitos e heterogêneos, parte deles fragmentou-se, perdeu ou redefiniu sua identidade, ideias e pontos de vistas centrais, alterando o projeto e a cultura política existente. Outros se redefiniram segundo as mudanças de outros atores sociais em cena. Outros ainda aproveitaram brechas e se conectaram com as possibilidades dadas pela globalização econômica (geradora de resistências e protestos) e cultural (geradora de novas sociabilidades, novas interações e aprendizagens baseadas na pedagogia do exemplo - aprender via observação - nos grandes eventos transnacionais, ou via conexão na rede Internet) (ver DELLA PORTA; DIANI, 2015) 


\title{
Quinto Ciclo - A Década de 2010 e as Pesquisas sobre os Movimentos Sociais a partir de 2013
}

\author{
$1^{\circ}$ momento: junho de 2013 - O Ponto de Inflexão
}

Após a crise do capitalismo global de 2008, movimentos e protestos dos 'indignados' ganham destaque em vários países, a população retoma as ruas como espaço de protestos logo no início da nova década. Surgem revoltas na Grécia, Espanha, Portugal; a Primavera Árabe atinge o Oriente Médio, na Tunísia, Egito, Turquia etc. e o movimento Occupy dos USA se espalha para várias partes do globo (GOHN, 2014 a). Entre os indignados, destacam-se o ativismo dos jovens e o uso das novas tecnologias. O perfil predominante dos participantes alterou-se de militante para um ativista. $\mathrm{O}$ militante tem filiações e compromissos coletivos com grupos, movimentos, partidos etc. O ativista não, atua em função de causas, muitas vezes de forma individual, não tem pertencimentos fixos, atua mais em coletivos do que em movimentos já consolidados. Estabelece relações horizontais e critica as hierarquias e as relações verticalizadas. As Marchas ou Manifestações nas ruas tornaram-se modelos básicos de protesto.

Assim, na virada da primeira década do novo século, um novo sujeito político ganha destaque: os indignados. No Brasil, sua presença se faz com força em junho de 2013, com manifestações em todo o Brasil, em movimentos de protestos contra políticas sociais vigentes nas áreas dos transportes, educação, saúde, prioridade dada aos gastos com a Copa do Mundo, entre outros motivos. Com os indignados, novíssimos atores entram em cena, especialmente jovens participantes de coletivos organizados online, tais como o MPL, Movimento Passe Livre, ou coletivos de estudantes secundaristas, além dos ativistas de causas transnacionais que, até então, não tinham quase visibilidade, como o Black Blocs (DEPIUS-DÉRI, 2014; SOLANO; MANSO; NOVAES, 2014). Novas orientações no campo teórico são incorporadas. Novos sujeitos entram no campo da pesquisa - grandes institutos de pesquisa de opinião pública, a exemplo do IBOPE, DATAFOLHA -, assim como organizam-se grupos de pesquisa na universidade e em centros de pesquisa para analisar as manifestações nas ruas após 2013. Existe um acervo razoável de estudos sobre 2013 entre eles, Alonso (2017); Figueiredo, (2014); Domingues e Bringel (2013); Ortellado et al. (2013); Gohn (2015) e Singer (2013). 
Os novíssimos sujeitos que entram em cena nas ruas e avenidas, a partir de junho de 2013, no caso brasileiro, representam uma nova onda de movimentos e coletivos sociais, diferente dos novos movimentos identitários organizados desde a década de 1980. Novos aportes teóricos entram em cena, especialmente as teorias do autonomismo ou socialismo libertário, que já estavam presentes na história das lutas sociais no Brasil, desde o início do século XX, em associações anarquistas e foram denominadas como anarcossindicalismo, num período que nem existiam sindicatos formais. $\mathrm{Na}$ década de 1960, os protestos dos autonomistas foram denominados como ‘contracultura' e minimizados. Na década de 1980, quando ocorreu o ciclo movimentalista dos 'novos movimentos sociais', tratados acima e subdivididos no campo popular (os movimentos de bairros urbanos, com demandas locais) e no campo dos movimentos por identidades (sexo, raça, etnia etc.), o tema da autonomia também esteve presente. Mas tratava-se de autonomia em relação aos partidos (tanto os que dominavam o status quo como os partidos de esquerda, até então tidos como clandestinos) e autonomia em relação ao Estado de plantão - o governo militar vigente. Por isso alguns analistas os denominaram "De costas para o Estado" (EVERS, 1983). Essa 'estratégia' da autonomia não tem nada a ver com a matriz do autonomismo que atualmente tem forte presença entre inúmeros movimentos e coletivos sociais, advinda do anarquismo, socialismo utópico ou individualismo do século XIX e início de XX, a exemplo de Proudhon (1981), Kropotkin (1979), e Nietzsche (1957). A ideia de autonomia surge a partir do desejo de liberdade, igualdade, justiça e independência de um governo que não é governo. A reorganização de sociedade deveria ocorrer através de associações livres de contato. As mudanças econômicas deveriam ter primazia em relação às políticas. As 'Sociedades de Ajuda Mútua' seriam os principais meios de realizar a mudança social sem violência, dado seu caráter. Seu objetivo deveria ser a ação e a cooperação econômica e não associação para a propaganda política. O sistema que caracterizaria esta nova sociedade foi denominado por Proudhon de Mutualista. Na realidade, as matrizes discursivas dos autonomistas podem ser localizadas desde o século XVI em R. Erasmo (2002), Thoreau (1975), La Boetie (2006), assim como em Rousseau (1968) e nos socialistas utópicos Owen e Fourrier (1977). Há os libertários e autonomistas de maio de 68 como Castoriadis (1975), Castoriadis e Cohn-Bendit (1981) e Daniel Cohn-Bendit (1988), a Internacional Situacionista de G. Debord (1995), e 
Marcuse (1967). Ou ainda há o pensamento de Foucault (1981), Antonio Negri e M. Hardt (2005), N. Chomsky (2011) e outros que dão subsídios para entender os autonomistas da atualidade e seus anseios de liberdade.

Portanto, neste novo século, os autonomistas ganharam foco e centralidade nas lutas sociais. Apesar de sua heterogeneidade, em termos de tendências e correntes internas, observa-se que são muito atuantes, na prática e na produção teórica (vide DAY, 2005; AUGUSTO; ROSA; RESENDE, 2016, entre outros). Eles estiveram presentes nas manifestações de estudantes no Chile, em 2011, e no Brasil, em junho de 2013 e nas ocupações dos estudantes secundaristas em 2015-2016. Em todos estes casos, as teorias 'autonomistas' tiveram grande vigor. Elas têm recriado as utopias, movem os estudantes e incendeiam as paixões dos jovens, nas respectivas gerações. Contestam o status quo, propõem um novo modelo de sociedade, destacam os indivíduos e suas ações e criticam o marxismo (vide AUGUSTO; ROSA; RESENDE, 2016).

O pensamento autonomista bebe também no humanismo, que cresceu e espalhou-se entre os ativistas da cibercultura (HESSEL, 2011; DUSSEL, 2005; SPIVAK, 2008; WALSH, 2005). Stéphane Hessel esteve em campos de concentração de judeus e participou da Resistência Francesa, escreveu com 93 anos um livreto "Indignai-vos!". O livro em poucos meses vendeu 1.500.000 exemplares e foi publicado em várias línguas. Ele "fez a cabeça” da maioria dos jovens que estão se indignando pelo mundo na década de 2010. A indignação é vista como um valor humano, essencial para a justiça social. Não se preconiza a violência ou atos terroristas, ao contrário, eles são condenados. Em síntese, outros aportes teóricos entram em cena como o socialismo libertário (DI CINTIO, 2010; DAY, 2005) e o novo humanismo holístico. A abordagem centrada no tema da autonomia e do socialismo libertário é também uma bandeira histórica do movimento dos povos indígenas - o mais amplo e intenso em termos de América Latina.

As utopias, que desde a queda do Muro de Berlim, há mais de 20 anos, eram criticadas e tidas como mortas, porque foram identificadas como totalitárias, ressurgem na década de 2010, lastreadas em referenciais libertários, para projetar o futuro, no qual não se sabe bem o que quer, mas sabe-se muito bem o que não se quer. Saliba (2004) chama este processo de distopia. Os manifestantes de junho de 2013 no Brasil defendem formas horizontais e não centralizadoras de organização, negam a presença de partidos nas mani- 
festações, mas não são antipartidários. Ao contrário, desde a década de 2010 estão gritando: outro mundo é possível. Qual mundo? Qual utopia? Talvez devêssemos seguir Riot-Sarcey, Picon e Bouchet que, no Dicionário das utopias (2009), afirmam ser melhor pensarmos na ausência de uma definição unívoca sobre o tema, mas reencontrar o sentido de uma construção imaginária, ou seja, retomar Thomas Morus, que em 1516 a caracterizou como um discurso sobre o não existente, um lugar que não existe ainda, um não lugar, mas um lugar onde se está bem.

Para concluir as influências teóricas sobre os autonomistas deve-se relembrar a teoria crítica e a produção de Habermas, da década de 1980. O que Habermas chamou de novos eram os movimentos feministas, ambientalistas, pacifistas etc. (vide ALONSO, 2009, p. 63). Estas análises têm sido recuperadas para analisar os movimentos dos estudantes secundaristas, os quais eu denomino como 'novíssimos', dadas as diferenças em relação aos novos da década de 1980, assim como suas diferenças em relação ao movimento predominante nas entidades estudantis do ensino superior, como a UNE, coordenada há décadas por militantes adeptos do Partido Comunista do Brasil.

Castells $(2013 ; 2018)$ ressurge no $5^{\circ}$ ciclo como teórico fundamental no estudo das manifestações, com enfoque diferente dos anos de 1970, agora focado no estudo das redes sociais e da Internet, que ele desenvolve desde o final dos anos 90 (CASTELLS, 1999). Atualmente ele destaca as teorias cognitivas das emoções que movem as pessoas a se indignarem. As emoções dos indivíduos e coletivos ganham destaque nos protestos políticos e podem assumir papel ativo da construção do social (CASTELLS, 2013). Muitos dos que protestam negam a política partidária atual. Há múltiplos processos de subjetivação na construção dos sujeitos em ação - os acontecimentos no calor da hora provocam reações que geram novas frentes da ação coletiva. A composição das mesmas é complexa, diversificada, com múltiplos atores, propostas e concepções sobre a política, a sociedade, o governo. Contudo, não basta focar nos indivíduos, nas organizações e nos eventos de protesto, como bem disse Diani e Bison (2010). É preciso observar também a multiplicidade de laços entre os diferentes atores, episódios ocorridos na conjuntura sociopolítica e cultural paralelos aos eventos que poderão lhes dar sentido e direção. A pluralidade de indivíduos, grupos e organizações presentes em uma manifestação deve ser analisada pelas redes de compartilhamento de 
crenças e pertencimentos, pelas interações informais e pelas identidades coletivas que vão construindo.

\section{$5^{\circ}$ Ciclo $-2^{\circ}$ Momento - Os conservadores em cena}

O desenrolar dos acontecimentos pós junho 2013 trouxe outros tipos de movimentos, neoliberais e conservadores, nas grandes manifestações nas ruas contra a corrupção, pelo impeachment da presidenta, entre 20152016. Eles atuam como organizações ou movimentos políticos (ver mais em GOHN, 2017a). Os conservadores e neoliberais são novidades após 2013, porque passaram a atuar também nas ruas, criaram organizações movimentalistas que se aproximam mais de movimentos políticos do que movimentos sociais. Defendem a desregulamentação de direitos sociais conquistados e a menor presença do estado na economia. Mas, de fato, miram o acesso ao poder político estatal. Na realidade, fazem parte de uma onda mais geral no capitalismo ocidental, de retorno de grupos conservadores ao poder, de desmonte de direitos e políticas sociais progressistas das últimas décadas, num momento de crise econômica, desemprego e grandes fluxos migratórios populacionais fugindo de regimes autoritários de toda natureza. Neste cenário, em que os movimentos sociais apresentam matrizes discursivas e ideológicas variadas e opostas, os novos grupos conservadores e neoliberais buscam teorias do passado para dar suporte às suas organizações movimentalistas, as quais se estruturaram no Brasil utilizando basicamente redes online. Após junho de 2013, mais de trinta grupos foram criados, destacando-se o "Vem Pra Rua” (ver CHEQUER; BUTTERFIELD, 2016), o Movimento Brasil Livre” $(\mathrm{MBL})$, entre outros. As matrizes teóricas e ideológicas que dão suporte às suas ideias são o liberalismo e a doutrina econômica de Hayek e Ludwing von Mises, a defesa do império da lei de Fréderic Bastiat e citações no campo da ciência política de E. Burke e Ortega y Gasset (ver GOHN, 2017a). No seu conjunto, esses grupos defendem propostas liberais para o papel do mercado e atuação do estado na economia, privatizações, estado mínimo e fim do financiamento de políticas públicas distributivas. Entretanto, alguns deles também defendem posições consideradas avançadas em relação aos liberais clássicos, ou aos conservadores tradicionalistas, como em questões da moral e costumes, a exemplo de suas posições em questões de gênero, gays etc. Por isso, confundem as pessoas. Mas continuam conservadores, porque 
são contra vários direitos sociais e culturais modernos. Apresentam-se como movimentos de 'renovação da política', mas são, na realidade, um retorno a movimentos nacionalistas do passado. Miram cargos públicos de poder, de Presidente da República a vereador local. Resumidamente são defensores do livre mercado, antiestatistas e neoliberais.

\section{Conclusões}

Sabe-se que nas Ciências Sociais se trabalha com teorias - enquanto ferramentas intelectuais que nos fornecem explicações para a compreensão dos fenômenos da realidade, assim como fornecem pistas para extrair possibilidades e delinear possíveis rumos sobre o futuro. Este artigo analisou várias teorias sobre os movimentos sociais e ações coletivas, agrupadas em cinco blocos interpretativos, mas nenhuma completamente consolidada nos marcos das especificidades locais do processo histórico brasileiro. O que dispomos é de um grande acervo de narrativas acerca de uma série de acontecimentos históricos em que os movimentos estão inseridos, a maioria deles analisada segundo teorias e categorias construídas em outros contextos históricos. De certa forma, predomina um processo de universalização do sentido das mesmas, sem grandes questionamentos. Entretanto, não se pode generalizar, há também tentativas de correlacionar as especificidades locais com as teorias, alguns denominam essas tentativas como as narrativas de paradigmas do Sul, as abordagens decoloniais. Vários estudos sobre os movimentos sociais no Brasil que se apoiaram nas teorias tratadas neste artigo são citados pontualmente como exemplos, mas reafirmo que eles não são analisados em si, tarefa árdua e necessária. O que se analisou são as teorias e autores advindos do exterior, que têm dado suporte aos estudos dos movimentos sociais no Brasil, através do material publicado ou apresentado em congressos no país e em português. Sabe-se que, recentemente, com a busca de internacionalização das pesquisas e programas de intercâmbio de Pós-Graduação, há inúmeras publicações sobre os movimentos do Brasil, em diferentes países e línguas.

Como resultado, este artigo apresenta cinco abordagens aglutinadas em blocos de teorias, em dados tempos históricos, dentro da conjuntura social, política e econômica do país. As análises levaram-nos a agrupar as abordagens teóricas em cinco ciclos específicos segundo as lutas, movimentos, 
protestos e mobilizações, e/ou as práticas de cooperação e participação em políticas institucionalizadas que ocorreram. Estes ciclos são: primeiro ciclo - na década de 1970, foi caracterizado pela fase de luta contra o regime militar e pela busca de saídas democráticas, com o predomínio de movimentos populares urbanos e análises neomarxistas. Segundo ciclo ocorre na década de 1980 com a reconstituição do processo democrático, lutas pela Diretas Já, processo constituinte e crescimento de novos movimentos sociais (de gênero, raça etc.) e predominância das análises segundo teorias culturalistas, identitárias. O terceiro ciclo, após a Constituição de 1988, caracterizou-se pela criação de instituições participativas ao longo das décadas de 1990 e o acirramento das lutas de movimentos sociais rurais. As teorias institucionalistas ganham força neste ciclo por focalizarem políticas institucionais de participação social desviando o foco da sociedade civil para as arenas do estado. O quarto ciclo, na década de 2000, continuou com o desenvolvimento de políticas de participação institucional e desenvolvimento das teorias institucionalistas, mas ocorre também o surgimento de novíssimos movimentos sociais, quer no plano internacional do altermundialismo (a exemplo do Fórum Social Mundial), quer no plano nacional, dos autonomistas (com a criação do MPL- Movimento Passe Livre, por exemplo). O quinto ciclo ocorre na década de 2010 com movimentos de indignados no plano internacional e a eclosão de um ponto de ruptura no plano nacional, em junho de 2013, com a volta de grandes manifestações nas ruas coordenadas por atores que até então não tinham visibilidade na cena pública ou nas políticas de relação ou inclusão, voltadas para setores dos movimentos organizados. São os autonomistas, liderados pelo MPL.

Após 2013, com a crise econômica, protestos e manifestações nas ruas, o tensionamento do processo democrático aumenta, levando a crise de representatividade das instituições participativas, descrença na política e emergência de outro tipo de novíssimos movimentos sociais, com espectros ideológicos distintos. São os conservadores, nacionalistas exacerbados ou neoliberais modernos. Os autonomistas crescem junto a grupos de jovens ao longo da década, mas entram e saem de cena continuamente. Em 2015, passam a atuar junto ao movimento de ocupação das escolas públicas do ensino básico, especialmente o ensino médio, os secundaristas. A conjuntura global influencia também as lutas locais e o movimento antiglobalização, juntamente com o movimento anticorrupção. Tais pautas inscrevem-se no 
cenário cotidiano da sociedade civil, que volta a ter importância no jogo político, como ocorreu na década de 1980.

Registre-se ainda que há saldos positivos dos ciclos anteriores quanto a participação em instâncias institucionalizadas, tais como: a constituição de redes de direitos e políticas públicas voltadas para atores centrais de determinados movimentos sociais, como os de gênero, especialmente o das mulheres, e o dos afrodescendentes. Foram conquistas que permanecem como núcleos de resistência às propostas de desregulamentação de direitos sociais adquiridos.

A reconstituição das abordagens segundo tempos e ciclos históricos comprovou a hipótese central deste artigo: em épocas de regime político fechado, as teorias críticas advindas do campo marxista tiveram campo maior de desenvolvimento, a exemplo da década de 1970. Em períodos de redemocratização, as teorias mais 'institucionalistas' e as teorias culturalistas identitárias proliferam mais rapidamente. Em períodos de crise econômica e crise de instituições da democracia, como tem ocorrido a partir de 2013 no Brasil, teorias libertárias ou autonomistas têm campo maior de desenvolvimento, assim como ressurgem novas versões de teorias conservadoras, nacionalistas.

Um dos grandes desafios para o futuro é construir categorias teóricas para pensar as especificidades da realidade brasileira, categorias que reflitam seu movimento real e suas diferenças em relação às teorias que têm sido suporte na maioria das análises, advindas das Teorias da Ação Coletiva do século XX, desenvolvidas especialmente nos Estados Unidos e na Europa. É necessário que essas teorias captem os significados dos movimentos, lutas e ações coletivas no contexto de países que passaram por colonização, escravidão de povos indígenas e escravidão de africanos. As categorias 'contentious politic's', ou suas estruturas de apoio como frames, repertórios; ou categorias mais culturalistas, como identidade, pertencimento, diversidade, diferença social; ou ainda as categorias marxistas, como luta, igualdade, conflitos, contradições etc., além das novas categorias dos indignados, ativistas da cibercultura, e outras de conteúdo moral ou simbólico, precisam ser confrontadas com as especificidades da realidade local. As categorias de cultura lastreadas nos aspectos identitários têm de incorporar também os aspectos políticos, a cultura política que os movimentos geram na sociedade. Eles são também fontes de saberes e aprendizados. Este desafio, que é coletivo e não tarefa de um só pesqui- 
sador, inscreve-se nos marcos de um diagnóstico que diz ser um dos problemas da América Latina, a descolonização do saber e do ser (enquanto repositório de práticas e valores que mantêm e reproduzem subjetividades e conhecimentos). São saberes estes mantidos por um tipo de economia que alimenta as instituições, as representações sobre a vida sociocultural de seu povo e os argumentos sobre os caminhos a seguir. Muitas categorias que utilizamos foram construídas em círculos acadêmicos que excluem ou minimizam os sujeitos das ações e movimentos de países do hemisfério Sul, e trabalham com noções de que existe uma única episteme ou forma de produzir conhecimento para a compreensão do mundo.

\section{Referências bibliográficas}

ABERS, Rebeca. (2016), Conflitos, Mobilizações e Participação Institucionalizada: a relação entre a sociedade civil e a construção de grandes obras de infraestrutura. Textos para discussão. Instituto de Pesquisa Econômica Aplicada. IPEA. Rio de Janeiro: IPEA.

ALMEIDA, Carla; CAYRES, Domitila Costa; TATAGIBA, Luciana. (2015), Balanço dos estudos sobre os conselhos de políticas públicas na última década. Lua Nova: Revista de Cultura e Política, v. 94, pp. 255-294.

ALONSO, Angela. (2009), As teorias dos movimentos sociais: um balanço do debate. Lua Nova, n. 76, pp. 49-86.

ALONSO, Angela. (2017), A política das ruas: protestos em São Paulo de Dilma a Temer. Novos Estudos: Cebrap, número especial: Dinâmicas da crise, pp. 49-58.

ARATO, Andrew; COHEN, Jean. (1992), Civil Society and Political Theory. 1 ed. Cambridge: The Mitt Press.

AUGUSTO, Acácio; ROSA, Pablo Ornelas; RESENDE, Paulo Edgar da Rocha. (2016), Capturas e resistências nas democracias liberais: uma mirada sobre a participação dos jovens nos novíssimos movimentos sociais. Estudos. Sociologia, v. 21, n. 40, pp. 21-37.

BORJA, Jordi. (1975), Movimientos Sociales Urbanos. 1 ed. Buenos Aires: Ed. SIAP.

BOSCHI, Renato. (1987). A Arte da Associação. 1 ed. São Paulo: Vértice.

BUTLER, Judith. (1993), Bodies that matter: on the discursive limits of sex. 1 ed. New York: Routledge.

CALDART, Roseli. (1997), Educação em movimento. 1 ed. Petrópolis: Vozes. 
CARDOSO, Ruth C. L. (1985), "Formas de Participação Popular no Brasil Contemporâneo” Revista Fundação SEADE, v. 1, n. 3, pp. 46-50.

CARLOS, Euzeneia; DOWBOR, Monika; ALBUQUERQUE, Maria do Carmo. (2017), Movimentos sociais e seus efeitos nas políticas públicas. Balanço do debate e proposições analíticas. Civitas, v. 17, n. 2, pp. 360-378.

CASTELLS, Manuel. (1999), A sociedade em rede. São Paulo: Paz e Terra.

CASTELLS, Manuel. (2013), Redes de Indignação e Esperança. Rio de Janeiro: Paz e Terra.

CASTELLS, Manuel. (2018), Ruptura. Rio de Janeiro: Zahar.

CASTELLS, Manuel. (1974), Movimientos Sociales Urbanos. Madri: Siglo XXI.

CASTORIADIS, Cornelius. (1975), L'nstituition Imaginaire de la Societé. Paris: Seuil.

CASTORIADIS, Cornelius; COHN-BENDIT, Daniel. (1981), Da Ecologia à Autonomia. São Paulo: Brasiliense.

CHEQUER, Rogerio; BUTTERFIELD, Colin. (2016), Vem Pra Rua: a história do movimento popular que mobilizou o Brasil. São Paulo: Matrix.

CHOMSKY, Noam. (2011), Notas Sobre o Anarquismo. São Paulo: Hedra.

COHN-BENDIT, Daniel. (1988), Nós que amávamos tanto a revolução. São Paulo: Brasiliense.

DAGNINO, E.; ALVAREZ, S.; ESCOBAR, A. (orgs.). (2000), Cultura e política nos movimentos sociais latino-americanos: novas leituras. Belo Horizonte: Ed. UFMG.

DAY, R. J. F. (2005), Gramsci is dead: anarchist currents in the newest social movements. Londres: Pluto.

DEBORD, Guy. (1995), A sociedade do espetáculo. São Paulo: Contraponto.

DELLA PORTA, Donatella; DIANI, Mário. (2015), The Oxford Handbook of Social Movements. Oxford: Oxford University Press.

DEPUIS-DÉRI, Francis. (2014), Black Blocs. São Paulo: Veneta.

DIANI, Mário; McADAM, Doug (Org.). (2003), Social movements and networks: relational approaches collective actions. Oxford: Oxford University Press.

DIANI, Mario; BISON, Ivano. (2010), Organizações, coalizões e movimentos. In: ABERS, Rebecca; VON BULOW, Marisa (Org.). Dossiê: Movimentos sociais e ação coletiva. Revista Brasileira de Ciência Política, n. 3, pp. 219-249.

DI CINTIO, Chloé. (2010), Petit traité de désobéissance civile. Paris: ResPublica. 
DOIMO, Ana M. (1984), Movimento Social Urbano, Igreja e Participação Popular. Petrópolis: Vozes.

DOIMO, Ana M. (1995), A vez e a voz do popular: movimentos sociais e participação política no Brasil pós-70. Rio de Janeiro: Relume-Dumará.

DOMINGUES, José Maurício; BRINGEL, B. (org.). (2013), Dossiê: As jornadas de junho em perspectiva global. Rio de Janeiro: Netsal; IESP/UERJ.

DUSSEL, Enrique. (2005), Europa, modernidade e eurocentrismo. In: LANDER, E. A colonialidade do saber: eurocentrismo e ciências sociais. Perspectivas latino-americanas. Buenos Aires: CLACSO. pp. 55-70.

EVERS, Tilman. (1983) "De costas para o Estado, longe do parlamento". Novos Estudos Cebrap. São Paulo. CEBRAP, v. 2, n. 1, pp. 25-39.

FOUCAULT, Michel. (1981), Microfísica do Poder. São Paulo: Graal

FIGUEIREDO, Rubens. (2014), Junho de 2013: a Sociedade Enfrenta o Estado. São Paulo: Summus,

FRASER, Nancy. (2001), Recognition without Ethics. Theory, Culture and Society, n. 18, pp. 21-41.

GOHN, Maria da Gloria. (2017a), Manifestações e protestos no Brasil: Correntes e contracorrentes. 1 ed. São Paulo: Cortez Editora.

GOHN, Maria da Gloria. (2017b), Teorias dos Movimentos Sociais. Paradigmas clássicos e contemporâneos. 12 ed. São Paulo: Loyola Edições.

GOHN, Maria da Gloria. (2017c), Movimentos sociais e educação. 10 ed. São Paulo: Cortez.

GOHN, Maria da Gloria. (2015), Manifestações de Junho de 2013 no Brasil e Praças dos indignados no mundo. 2 ed. Petrópolis: Ed Vozes.

GOHN, Maria da Gloria. (2014a), Sociologia dos movimentos sociais. 2 ed. São Paulo: Cortez Editora.

GOHN, Maria da Gloria. (2014b), Novas teorias dos movimentos sociais. 5 ed. São Paulo: Loyola.

GOHN, Maria da Gloria. (2013), Movimentos sociais e redes de mobilizações civis no Brasil Contemporâneo. 7 ed. Petrópolis: Vozes.

GOHN, Maria da Gloria. (1995), Movimentos e Lutas Sociais na História do Brasil. 1 ed. São Paulo: Loyola.

GOHN, Maria da Gloria. (1982), Reivindicações Populares Urbanas. 1 ed. São Paulo: Cortez.

GOHN, Maria da Gloria. (1985), A Força da Periferia. 1 ed. Petrópolis: Vozes. GOHN, Maria da Gloria. (1991), Movimentos Sociais e Lutas pela Moradia. 1 ed. São Paulo: Loyola. 
HABERMAS, Jürgen. (1981), “New Social Movements”. Telos, n. 49, p. 33-45. HABERMAS, Jürgen. (1985), Teoria de la Acción Comunicativa. Madri: Taurus. HARVEY, David. (2011), O Enigma do capital e as crises do capitalismo. São Paulo: Boitempo.

HESSEL, Stéphane. (2011), Indignai-vos! 3 ed. Lisboa: Editora Objetiva. HOBSBAWM, Eric. (1970), Rebeldes Primitivos. Rio de Janeiro: Zahar. HONNETH, Axel. (2003), Luta por reconhecimento. A gramática moral dos conflitos sociais. São Paulo: Editora 34.

KAUCHAKJE, Samira. (1997), Movimentos Sociais na Academia: um olhar sobre as teses e dissertações produzidas na USP e na Unicamp entre 19711995. Tese de Doutorado - Programa de Pós-Graduação em Educação. Campinas: Universidade Estadual de Campinas. Orientação Maria da Glória Gohn.

KLANDERMANS, Bert. (1984), "Mobilization and Participation: Social Psychological Expansions of Resource Mobilization Theory”. American Sociological Review, n. 49, pp.194-234.

KOWARICK, L. (1987), "Movimentos sociais urbanos no Brasil contemporâneo: uma análise da literatura”. Revista Brasileira de Ciências Sociais, v. 1, n. 3, pp. 30-42.

KROPOTKIN, P. (1979), "Sobre o Governo Representativo ou Parlamentarista”. In: MALATESTA, Errico et al. O Anarquismo e a Democracia Burguesa. São Paulo: Global.

LA BOÉTIE, Étienne de. (2006), Discurso Sobre a Servidão Voluntária. L.C.C. Publicações Eletrônicas. Disponível: <http://www.miniweb.com.br/biblioteca/Artigos/servidao_voluntaria. Acesso em: 08 fev. 2017.

LINERA, Álvaro G. (2009), Sociologia dos movimentos sociais. São Paulo: Boitempo.

MCADAM, Doug. (1982), Political Process and the Development of Black Insurgency, 1930-1970. Chicago: University of Chicago Press.

MCADAM, Doug. (1994), "Culture and Social Movements”. In: LARANA, E.; JOHNSTON, H.; GUSFIELD, J. New Social Movements. Philadelphia: Un. Temple. pp. 36-57.

MCADAM, Doug; MCCARTHY, John D.; ZALD, Mayer N. (1996), Comparative perspectives on social movements. Cambridge: Cambridge University Press.

MARCUSE, Herbert. (1967), A ideologia da sociedade industrial. Rio de Janeiro: Zahar.

MELUCCI, Alberto. (1976), Sistema Político, Partiti e Movimenti Sociali. Milano: Feltrinelli. 
MELUCCI, Alberto. (1980), The New social Movements: A Theoretical Approach. Social Science Information, n. 19, pp. 199-226.

MELUCCI, Alberto. (1989), Nomads of the Present: Social Movements and Individual Needs in Contemporary Society. Philadelphia: Temple University Press,

MELUCCI, Alberto. (1996), Challeging codes. Cambridge: Cambridge Press.

MEYER, David S.; MINKOFF, Debra C. (2004), Conceptualizing political opportunity. Social Forces, v. 82, n. 4, pp. 1457-1492.

MILANI, Carlos R. S. (2008), O princípio da participação social na gestão de políticas públicas locais: uma análise de experiências latino-americanas e europeias. RAP - Revista de Administração Pública - FGV, v. 42, n. 3, pp. 551-579.

MIGNOLO, Walter D. (2003), Histórias locais, projetos globais: Colonialidade, saberes subalternos e pensamento liminar. Belo Horizonte, UFMG.

NEGRI, Antonio; HARDT, Michael. (2005), Multidão. Rio de Janeiro: Record. NIETZCHE, Friedrich. (1957), La Gai Savoir, la Gaya Scienza. Paris: Club Français du Livre.

OFFE, Claus. (1983), New Social Movements as a Metal Political Challenge. Bielefeld: University of Bielefeld.

OFFE, Claus. (1985), "New Social Movements: Challenging the Boundaries of Institutional Politics”. Social Research, n. 52, pp. 817-868.

OFFE, Claus. (1988), Partidos politicos y Nuevos Movimientos Sociales. Madri: Sistema.

OLSON, Mancur. (1965), The Logic of Collective Action. Cambridge: Cambridge University Press.

ORTELLADO, Pablo et al. (2013), Vinte centavos: a luta contra o aumento. São Paulo: Veneta.

OWEN, Robert; FOURRIER, Charles. (1977), Le proposte dei socialisti utopisti: Importanza e limiti storici dei modelli degli utopista. In: SICCA, Paolo. Storia délla urbanística: l'ottocento. Roma: G. Laterzae F. Spa. pp.1082-1088.

PROUDHON, Pierre J. (1981), “A Velha e a Nova Sociedade”: In: WOODCOK, George. Anarquistas. Porto Alegre: LPM. pp. 40-55.

QUIJANO, Aníbal. (2004), El laberinto de América Latina: ¿hay otras salidas?. Revista OSAL, Buenos Aires: CLACSO, v. 5, n. 13, pp. 15-30.

QUIJANO, Aníbal. (2005), “Colonialidade do poder, eurocentrismo e América Latina”. In: LANDER, Edgard (Org.). A colonialidade do saber: eurocentrismo e ciências sociais. Perspectivas latino-americanas, Colección Sur Sur. Buenos Aires: CLACSO. pp. 122-151. 
RIOT-SARCEY, Michèle; PICON, Antoine; BOUCHET, Thomas. (2009), Dicionário das utopias. São Paulo: Edições \&Textos.

ROUSSEAU, Jean J. (1968), The social contract. New York: Penguin Books. ROTTERDAM, Erasmo de. (2002), Elogio da loucura. São Paulo: Martin Claret. SADER, Eder. (1988), Quando novos personagens entraram em cena. Rio de Janeiro: Paz e Terra.

SALIBA, Elias Thomé. (2004), As utopias românticas. 3 ed. São Paulo: Estação Liberdade.

SCHERER-WARREN, Ilse. (1993), Redes de Movimentos Sociais. São Paulo: Loyola.

SILVA, Luiz Antônio Machado da; RIBEIRO, Ana Clara Torres. (1985), Paradigma e movimento social: Por onde vão nossas ideias. Ciências Sociais Hoje. São Paulo: ANPOCS; Cortez. pp. 318-336.

SINGER, André. (2013), "Brasil, junho de 2013: classes e ideologias cruzadas”. Novos Estudos - CEBRAP, n. 97, pp. 23-40.

SIRVENT, Maria Tereza. (2008), Educación de adultos: investigación, participación, desafios y contradicciones. 2 ed. Buenos Aires: Minõ Dávila.

SOLANO, E.; MANSO, B. P.; NOVAES,W. (2014), M@scAr@dos: a verdadeira história dos adeptos da tática Black Blocs. São Paulo: Geração Editorial.

SPIVAK, Gayatri C. (2008), Estudios de La subalternidad. In: SPIVAK, G. et al. Estudios postcoloniales - Ensayos fundamentales. Madri: Queimadas Graficas.

TAPIA, L. (2009), Movimientos sociales, movimientos societales y los no lugares de la política. Cuadernos del Pensamiento Crítico Latinoamericano, n. 11. Buenos Aires: CLACSO. pp. 15-30.

TARROW, Sidney. (1994), Power in movement. 1 ed. Cambridge: Cambridge Press.

TARROW, Sidney. (2005), New Transnational Activism. 1 ed. Cambridge: Cambridge Press.

TARROW, Sidney; DELLA PORTA, Donatella. (2005), Transnational protest and global activism. London: Rowman \& Littlefield Publis.

THOREAU, Henry. (1975), A desobediência civil. São Paulo: Cultrix.

THOMPSON, E. P. (2004), A miséria da teoria. Rio de Janeiro: Zahar.

TILLY, Charles. (1978), From Mobilization to Revolution. Londres: AddisonWesley; Publishing Company.

TILLY, Charles. (1983), "Speaking Your Mind Without Elections, Surveys, or Social Movements”. Public Opinion, Quarterly, n. 47, pp. 461-478. 
TILLY, Charles. (1986), The Contentious French. Cambridge: Cambridge University Press.

TILLY, Charles. (1993), European Revolutions, 1492-1992. Oxford: Blackwell. TILLY, Charles. (1994), "History and Sociological Imagining”. Toqueville Review, n. 15, pp. 57-72.

TILLY, Charles. (1995), Popular contention in Great Britain, 1758-1834. Cambridge: Harvard University Press.

TILLY, Charles; TARROW, Sidney; McADAM, Doug. (2001), Dynamics of contention. Cambridge: Cambridge University Press.

TILLY, Charles; TARROW, Sidney. (2006), Contentious Politics. Boulder: Paradigm Pub.

TILLY, Charles. (2007), Democracy. Cambridge: Cambridge University Press.

TILLY, Charles. (2006), Regimes and Repertoires. Chicago: University of Chicago Press.

TOURAINE, Alain. (1965), Sociologie de l'action. Paris: Seuil.

TOURAINE, Alain. (1973), Production de la Société. Paris: Seuil.

TOURAINE, Alain. (1977), "Movimentos Sociais e Ideologias nas Sociedades Dependentes”. In: ALBUQUERQUE, J. A. G. (org.). Classes Médias e Política no Brasil. Rio de Janeiro: Paz e Terra.

TOURAINE, Alain. (1978), Le Voix et le Regard. Paris: Seuil.

TOURAINE, Alain. (1984), Le Retour de l'Acteur. Paris: Fayard.

TOURAINE, Alain. (1985), “The Study of Social Movements”. Social Research, v. 52, n. 4, pp. 749-787.

TOURAINE, Alain. (1989), Palavra e Sangue. Campinas: Ed. UNICAMP.

TOURAINE, Alain. (1994), Qu'ést-ce la democracie. Paris: Seuil.

WALSH, Catherine. (2005), "Introducción (re)pensamiento critico y (de)colonialidad”. In: WALSH, C. (org.). Pensamiento crítico y matriz (de)colonial, reflexiones latinoamericanas. Quito: Universidad Andina Simón Bolívar; Ediciones Abya-Yala.

ZIZEK, Slavoj. (2011), Primeiro como tragédia, depois como farsa. São Paulo: Boitempo.

ZIZEK, Slavoj. (2012), O ano que sonhamos perigosamente. São Paulo: Boitempo. 


\title{
Inovações Temáticas, “Guinadas” Teóricas e Tradição Intelectual no Brasil
}

\author{
Wilson José Ferreira de Oliveira* \\ Fernanda Rios Petrarca**
}

\section{RESUMO}

Esse artigo analisa a produção acadêmica das ciências sociais brasileiras sobre a temática "elites". Pretende-se dar conta tanto das inovações quanto dos problemas e desafios que ainda persistem na produção brasileira sobre o tema. Trata-se, primeiramente, de examinar os principais objetos, problemáticas teóricas e avanços metodológicos dos estudos recentes sobre grupos dirigentes no Brasil. Em segundo, trata-se de apreender a dinâmica de acesso aos principais espaços de produção das ciências sociais no país, as concentrações regionais e as redes de pesquisadores vinculados ao tema. Tais resultados evidenciam a pertinência de uma agenda de pesquisa reflexiva que leve em conta as condições e características próprias de construção dos grupos dirigentes em situações como a brasileira e que recuse a utilização "dedutivista" e "reificante" de teorias, conceitos e metodologias importadas.

Palavras-chave: Elites. Teoria. Sociologia Brasileira. Tradição Intelectual. Pesquisa Reflexiva.

\footnotetext{
Doutor em Antropologia Social; Professor Associado 3 do Departamento de Ciências Sociais e Programa de Pós-Graduação em Sociologia da UFS.

** Doutora com pós-doutoramento em Sociologia pela UFRGS; Professora Associada 1 do Departamento de Ciências Sociais e do Programa de Pós-Graduação em Sociologia da UFS.
} 


\begin{abstract}
THEMATIC INNOVATIONS, THEORETICAL “TURN” AND INTELLECTUAL TRADITION IN BRAZIL
\end{abstract}

This article analyzes the academic production of the Brazilian social sciences on the theme "elites". The aim is to analyze both the innovations and the problems and challenges that still persist in Brazilian production on the subject. First, we examine the main objects, theoretical problems and methodological advances of recent studies on elites in Brazil. Second, we try to understand the dynamics of access to the main production spaces of the social sciences in the country, regional concentrations and networks of researchers linked to the theme. These results evince the pertinence of a reflective research agenda on the subject: to take into account the conditions and characteristics in the making of elites in the Brazilian situation; and to reject the "dedutivistic" and "reifying" use of imported theories, concepts and methodologies. Keywords: Elites. Theory. Brazilian Sociology. Intellectual Tradition. Reflective Research./

\title{
Introdução
}

Nos últimos anos, diferentes espaços da produção intelectual brasileira realizaram balanços sistemáticos sobre o estado da arte das ciências sociais no país, num claro desafio autorreflexivo. São exemplos disso as coletâneas “O que ler na Ciência Social Brasileira”, lançada em 1999 em três volumes sob a organização de Sérgio Miceli, e "Horizontes das Ciências Sociais no Brasil”, lançada em 2010 também em três volumes sob a coordenação de Carlos Benedito Martins e Renato Lessa. Acrescentem-se a isso os esforços continuados da BIB - Revista Brasileira de Informação Bibliográfica em Ciências Sociais - de produzir não só artigos sobre a produção bibliográfica a partir das mais variadas temáticas, como também a mais recente publicação, de 2017, "Sociologia Brasileira Hoje”, organizada por Carlos Benedito Martins e Sérgio Miceli numa iniciativa da Sociedade Brasileira de Sociologia (SBS), e por fim, em 2018, os dois volumes da Revista Brasileira de Sociologia (da SBS) dedicados ao tema da sociologia brasileira.

Esse material oferece contribuições significativas para se compreender as temáticas priorizadas, as perspectivas teóricas valorizadas e os tratamentos metodológicos utilizados pelos cientistas sociais brasileiros. Além disso, ele 
oferece um quadro amplo sobre as características e a dinâmica da produção nacional, ao evidenciar os objetos privilegiados, as correntes teóricas dominantes, o posicionamento dos cientistas sociais diante delas e as principais transformações ocorridas no decorrer de diferentes períodos. Em consonância com tais contribuições, este artigo analisa a produção acadêmica das ciências sociais brasileiras sobre a temática "elites". Trata-se, por um lado, de apreender a dinâmica de acesso aos principais espaços de produção das ciências sociais no país, as concentrações regionais e as redes de pesquisadores vinculados ao tema. De outro, trata-se de examinar os principais objetos, problemáticas teóricas e avanços metodológicos dos estudos recentes sobre grupos dirigentes no Brasil.

Tal formulação remete a discussões e problemáticas teóricas relacionadas aos estudos dos movimentos intelectuais e da circulação internacional das ideias. De um lado, tais perspectivas têm salientado que a expansão de uma teoria depende de um trabalho social organizado, como forma de ação coletiva, e do reconhecimento de lideranças capazes de disputar no cenário internacional (FRICKEL; GROSS, 2005). Nesse sentido, trata-se de compreender a capacidade de certos movimentos intelectuais de ter acesso a recursos importantes (publicação, citação e circulação), de colocar em prática processos de micromobilização (recrutamento de novos membros) e de investimentos em capital social. De outro lado, salienta-se que tal circulação depende de efeitos estruturais internos conectados ao uso estratégico de textos e autores no campo nacional (BOURDIEU; WACQUANT, 1998; BOURDIEU, 2002). Isso implica nos voltarmos para as disputas intelectuais internas, os vínculos estabelecidos com autores situados no âmbito internacional e os usos estratégicos de autores e referências como forma de se distinguir no espaço de concorrência nacional.

No que pese a inovação teórica e a relevância dos aspectos levantados por tais perspectivas, um dos problemas por elas ignorado tem sido a análise das assimetrias intelectuais e do papel do colonialismo no processo de circulação, de imposição e de importação de ideias (MAIA; CARUSO, 2012). Nesta direção, o caso brasileiro traz uma contribuição pertinente para o estudo de tais processos de circulação de ideias e de movimentos teóricos, na medida em que se trata de uma tradição intelectual e acadêmica que foi construída numa relação de forte dependência dos centros dominantes (MAIA; CARUSO, 2012; COSTA, 2010). Desse modo, um dos elementos centrais que já tem 
sido apontado por outros trabalhos é que nesse caso a produção intelectual tem como base a recorrente tensão entre "imitação" e "autenticidade": ou ela importa, numa perspectiva de imitação, os dilemas transacionais ou ela se volta especificamente para problemas próprios e às vezes tidos como exclusivos da dinâmica nacional (MAIA; CARUSO, 2012). Se, por um lado, a preocupação com o "dilema nacional” ou com a "singularidade brasileira” impediu os cientistas sociais de lançarem os problemas estudados num universo mais amplo, por outro, a importação de modelos e teorias não se traduziu, na maioria das vezes, na reformulação crítica, mas serviu apenas de recurso para distinção e concorrência internas. Tal tensão traz como um dos efeitos mais perversos para a produção teórica nacional a dificuldade em inscrever problemas estudados, construídos a partir de casos empíricos pautados na realidade brasileira, em problemáticas mais gerais e, portanto, traduzíveis em questões universais.

Com base nisto, a leitura destas coletâneas sobre a sociologia brasileira, apesar de tratar de diversas temáticas, nos permitiu construir alguns eixos de investigação que têm caracterizado a pesquisa e a produção intelectual no Brasil. Dentre as características que têm predominado na nossa produção intelectual, destaca-se o caráter fragmentário dos grupos, o que conduz a recorrentes disputas entre redes de pesquisadores e, por vezes, à concentração regional. Associada a isto está, também, a continuidade de uma "tradição intelectual” fundada não só na importação de modelos e teorias eurocêntricas produzidas na Europa e nos Estados Unidos, como no desconhecimento das formulações teóricas, conceituais e metodológicas da produção nacional em sua área (BRANDÃO, 2010). Uma das principais consequências disso é que os cientistas sociais brasileiros assumem uma "posição subordinada na geopolítica mundial do conhecimento sociológico” (BRANDÃO, 2010, p. 45), restringindo-se a aplicar conceitos e técnicas importadas para compreender a dinâmica da sociedade brasileira, o que os remete a aludida tensão entre "imitação" e "autenticidade".

Nessa direção, mobilizamos a noção de "guinada" como uma forma de apreender esse processo de produção de teorias e ideias, levando em conta tanto as disputas e concorrências internas quanto os efeitos do espaço internacional nos confrontos nacionais. Deste modo, nos referimos a sucessivas mudanças de orientações na produção nacional como novas "guinadas” teóricas. Isso porque o que está em jogo a cada renovação é o estabelecimento de novos pontos 
de partida com base na importação de novos autores, abordagens, conceitos e mesmo metodologias. Para isso, a produção acadêmica nacional é praticamente ignorada, como se inexistissem estudos anteriores sobre tal temática.

Partimos da hipótese de que esta tensão está socialmente fundada na dinâmica própria do movimento intelectual nacional, que tem como base a fragmentação das redes de pesquisadores nacionais e a forte concorrência interna entre diferentes centros regionais de pesquisa. Tal fragmentação dificulta o "trabalho social organizado" de expansão teórica (FRICKEL; GROSS, 2005), impedindo que a ação intelectual coletiva produza lideranças capazes de disputar no cenário internacional. Do mesmo modo, as disputas internas entre redes regionais de pesquisadores são marcadas por recorrentes importação de autores e escolas como signos de distinções internas, passando de um momento em que eram pautadas pela "interpretação dos problemas nacionais" para outro em que se dão em torno da "interpretação de escolas e autores" dominantes nos centros dominantes (a saber Europa e EUA).

Com base nisto, buscamos neste artigo não só fazer um balanço, mas apresentar um levantamento crítico dos fundamentos teóricos e metodológicos dos estudos sobre elites no Brasil, considerando tanto a renovação trazida por um conjunto de abordagens e as problemáticas novas que elas levantaram, quanto as ausências, os esquecimentos e as dificuldades vinculadas à construção de linhas de investigação sólidas que tomem os grupos dirigentes como objeto de análise. Devido à diversidade e até mesmo à dispersão dos espaços de produção acadêmica sobre essa temática (eventos, revistas, livros), partimos do material publicado no Grupo de Trabalho (GT) sobre elites do Encontro Anual da Associação Nacional de Pesquisa e Pós-Graduação em Ciências Sociais (ANPOCS).

Sabemos que a produção acadêmica na área de elites no Brasil não se limita aos GTs da ANPOCS, sendo bem mais ampla e diversificada. Um estudo completo deveria, certamente, levar em conta várias instâncias institucionalizadas de produção e difusão científica. Dadas as condições de realização desta pesquisa, optamos pelo recorte dos trabalhos publicados no GT Elites da ANPOCS, tendo em vista, pelo menos, três elementos fundamentais (SAINT-MARTIN, 1988; COSTA, 2010): primeiro, a reunião anual da ANPOCS tem um peso significativo no trabalho político de representação, de constituição de instâncias de legitimação, difusão e consagração particularmente importantes e visíveis no cenário das ciências sociais nacional; em 
segundo lugar, um novo GT não se constitui e se mantém se não tiver uma ampla articulação de redes de pesquisadores vinculados a diferentes centros regionais de ensino e pesquisa; por fim, a ANPOCS e os encontros anuais por ela promovidos tornaram-se um dos principais espaços de discussão, de promoção e de reconhecimento das principais lideranças intelectuais no âmbito das ciências sociais brasileiras. Com base nisto, consideramos que as apresentações, discussões e publicações do GT Elites da ANPOCS constituem um material suficientemente representativo das formas de produção e de uso de teorias sobre grupos dirigentes no Brasil, concentrando os principais pesquisadores da área e refletindo os principais polos de produção da temática no país.

Nosso ponto de partida é constituído por dois bancos de dados construídos a partir de um levantamento dos trabalhos apresentados no GT Elites da ANPOCS - desde 1979 até 2015. O primeiro banco analisa os coordenadores, debatedores e apresentadores, considerando: sexo, área de formação, universidade em que concluiu sua titulação mais alta, universidade ou instituição em que atua, titulação, orientador, orientação teórica, temática empírica, tipo de participação no GT (apresentador, debatedor, coordenador). O objetivo principal deste banco é o de identificar a circulação nacional dos principais grupos de pesquisa vinculados à temática das elites, as orientações teóricas dominantes e os objetos empíricos priorizados. Além disso, ele nos permite apreender os vínculos entre os membros do grupo e a formação de uma rede de pesquisadores que passa a ocupar um lugar central na definição das temáticas, das abordagens e suas respectivas áreas de concentração e região de produção. Já o segundo banco contém informações sobre as referências bibliográficas citadas nos artigos publicados, com o intuito de examinar o lugar da produção intelectual nacional e internacional nos trabalhos apresentados no GT. Como os artigos apresentados e publicados só estão disponíveis para acesso a partir de 2007, só conseguimos analisar o perfil da bibliografia mobilizada da fase mais recente do grupo, o que nos impediu de fazer uma comparação mais ampla com o período anterior ${ }^{1}$.

1 O Grupo de Trabalho sobre elites, no encontro da ANPOCS, teve dois momentos principais: um primeiro organizado de 1979 até 1996, com algumas interrupções, e um segundo, organizado a partir de 2007. Há, portanto, um vácuo de dez anos desta temática no principal encontro de cientistas sociais do país. Esses dois momentos possuem características bem diferentes. Muitos pesquisadores da primeira fase mudaram seus objetos e migraram para outros grupos de trabalho, demonstrando, portanto, uma descontinuidade. 
Para dar conta dessas questões, o texto está dividido em três momentos principais. Num primeiro momento, analisaremos a primeira fase de emergência e organização da temática e o papel que exerceram as disputas institucionais entre "uspianos" versus "iuperjianos". Num segundo momento, demonstraremos como "a guinada" bourdieusiana representou um conjunto de mudanças significativas, não só na problematização deste objeto como na diversificação regional e na ampliação das redes de pesquisadores. E, por fim, destacaremos o lugar que assume a referência bibliográfica nacional e internacional mobilizada nas pesquisas realizadas e o que ela nos diz sobre as teorias, autores e modelos de análise mais utilizados.

Um dos traços marcantes nas investigações que caracterizaram estes diferentes momentos do estudo sobre as elites no Brasil é que elas foram profundamente orientadas pelas problemáticas, conceitos e metodologias em voga no espaço acadêmico internacional e, mais recentemente, pelo confronto entre intérpretes "institucionalistas" versus "bourdieusianos". Essa orientação levou a certo afastamento e mesmo negligência de uma longa tradição de estudos centrados nas condições e processos de composição e recomposição de elites e grupos dirigentes no Brasil. Dentre os temas que foram esquecidos, classificados como historicamente datados e ultrapassados, cabem salientar os estudos com ênfase na dinâmica histórica, como aqueles que se voltaram para o exame do fenômeno do "coronelismo", do "mandonismo" e das "relações pessoais". Além disso, a renovação temática ocorrida a partir dos anos 2000 não ocorreu com base no confronto, crítica ou diálogo com os pesquisadores, as investigações e a ampla produção do período anterior. Antes disso, foi novamente a recorrência a teorias, problemáticas e modelos externos que esteve na base dos principais confrontos e polarizações. Tal ausência constitui, sem dúvida, um dos traços marcantes da recorrente tensão entre "autenticidade” e "imitação", do caráter fragmentário das redes e grupos de pesquisadores, e do uso estratégico de teorias reconhecidas nos centros dominantes para distinção intelectual interna.

\section{Os Estudos de Elites no Brasil: entre "uspianos" e "iuperjianos"}

Os estudos de elites - no sentido do estudo dos indivíduos que ocupam uma posição dominante na definição e distribuição de recursos em diferentes espaços sociais - constituem uma longa tradição nas ciências sociais, 
destacando-se como uma importante área de investigação e objeto legítimo de pesquisa que tem suscitado divergentes interrogações, problemas de pesquisa e problemáticas teóricas e conceituais (CODATO; PERISSINOTTO, 2008; CORADINI, 2008; GRYNSZPAN, 1996).

No Brasil, a temática "elites” recebeu atenção das ciências sociais a partir do final dos anos de 1970. Caracterizado pelo seu forte teor marxista, foi no âmbito das reformulações mais recentes, observadas no âmbito internacional, que o interesse por esse objeto passou por um conjunto de transformações. O banco de dados produzido a partir dos trabalhos apresentados no "GT Elites”, da Associação Nacional de Pesquisa e Pós-Graduação em Ciências Sociais (ANPOCS), de 1979 a 2015, evidencia o crescimento deste objeto e a sua distribuição no espaço acadêmico brasileiro, bem como os principais temas e abordagens privilegiadas e as áreas em que dominaram as investigações deste objeto.

A partir da análise do material publicado no GT, é possível afirmar que a produção acadêmica brasileira sobre elites tem se caracterizado pela formação e pelo confronto entre duas grandes orientações teóricas. De um lado, há uma "sociologia política”, cujo foco central é a análise das condições históricas e sociais de constituição de grupos e instituições políticas. Mais recentemente, esta perspectiva esteve vinculada aos trabalhos cuja orientação teórica se aproxima dos estudos de Pierre Bourdieu, principalmente após 2010 com a mudança na coordenação do grupo. De outro, uma há "ciência política”, centrada no exame comportamentalista e internalista do papel das instituições no processo político e de suas relações com as elites políticas. Isso pode ser observado na primeira fase do GT, de 1979 até 1996, e nos primeiros anos da segunda fase, mais propriamente de 2007 até 2009. Apesar dessa relativa mudança de orientação nos últimos anos, persiste para todo o período analisado o predomínio da ciência política como área central no estudo deste objeto.

Num primeiro momento (1979-1996), essas diferenças eram marcadamente institucionais, colocando em posições opostas a "escola de sociologia” da USP ("uspianos”), que tinha uma clara orientação "francesa”, e a "ciência política" feita na UFMG e no IUPERJ (os “iuperjianos”), de orientação norte-americana. Neste contexto, a renovação teórica em direção ao comportamentalismo norte-americano constituiu uma estratégia para a imposição da ciência política no âmbito nacional. Num segundo momento, em meio 
a um processo de expansão do sistema universitário e, principalmente, da pós-graduação, trata-se de uma maior diversificação das redes de pesquisadores vinculados ao tema. Desse modo, a renovação teórica toma a forma de uma oposição e concorrência interna entre, de um lado, os herdeiros da sociologia das elites anglo-saxã, cujo foco central é a célebre indagação "quem governa”, caracterizando-se ora por uma abordagem comportamentalista e internalista das instituições ora por um caráter quantitativista e individualista marcante em termos metodológicos, e, de outro, os que se vinculam aos trabalhos de Bourdieu e sua equipe e que se centram na investigação não só dos processos de recrutamento e seleção das elites em diferentes esferas, os quais enfatizam as relações objetivas entre indivíduos e propriedades que os aproximam ou os opõem, como também do estado das relações de forças entre as estruturas de recursos e de capitais mobilizados, bem como dos princípios legítimos de dominação em luta para sua imposição.

Levando em consideração os coordenadores, nessa primeira fase, pode-se observar uma forte concentração de pesquisadores do Sudeste, manifestada por um revezamento inicial entre São Paulo, com forte presença da Fundação Getúlio Vargas e Universidade de São Paulo (USP), e Rio de Janeiro, representado pela IUPERJ e UFF. São estas as universidades e regióes que passam a exercer um papel central na forma de se estudar o tema nesse período.

Essa divisão entre São Paulo e Rio de Janeiro não é, entretanto, uma característica peculiar dos estudos de elites e desse campo de conhecimento. Ao contrário, ela é o reflexo de uma polarização entre a escola paulista de sociologia política, desenvolvida na USP, e os estudos cariocas, concentrados no IUPERJ. Tradicionalmente, a sociologia política "uspiana” apresentou uma forte vinculação com a produção francesa, dando origem a abordagens centradas no caráter sócio-histórico e numa aproximação maior com a sociologia e com a filosofia (LESSA, 2010). A “escola sociológica da USP”, como ficou conhecida, produziu um conjunto de estudos, teses, dissertações, cuja orientação teórica estava vinculada às correntes marxista e estrutural funcionalista (FORJAZ, 1997; LESSA, 2010). São exemplos disso os trabalhos de Francisco Weffort sobre o peso do populismo na política brasileira; o de Maria do Carmo Campello sobre o "Processo político partidário na Primeira República", publicado pela primeira vez em 1967, e sua tese "Estado e Partidos Políticos no Brasil”; o de Sebastião Velasco a respeito da relação entre empresários e o Estado; e o de Sérgio Miceli que se voltou para análise dos 
intelectuais e classes dirigentes no Brasil. É a partir deste grupo que é fundado, em 1981, o Instituto de Estudos Econômicos, Sociais e Políticos (IDESP). O ponto forte destes estudos era o exame da estrutura e dinâmica institucional, com ênfase no processo sócio-histórico.

Em contraponto a isso, o núcleo central da institucionalização da ciência política no Brasil é formado pelo IUPERJ e o Departamento de Ciência Política da UFMG (FORJAZ, 1997). Ambos contaram com apoio financeiro da Fundação Ford ${ }^{2}$, inaugurando os cursos de pós-graduação na área e marcando uma forte oposição ao "modelo uspiano”, que, segundo eles, apresentava-se demasiado marxista e estrutural, deixando pouco espaço para a análise da "política como uma esfera autônoma da realidade social, com determinações próprias não subordinadas às esferas econômica, social ou cultural" (FORJAZ, 1997, p. 9). É justamente a ambição de "destacar a autonomia das 'meras formas político-institucionais', que não são apenas reflexos da vida social e econômica", o que constitui o traço marcante da atuação do "grupo mineiro/carioca” (p. 12).

Diante disso, a guinada "behaviorista”, de marcada orientação norte-americana, da ciência política desenvolvida pelos "iuperjianos/mineiros" constituiu um recurso importante na defesa da institucionalização dessa área e na forma de abordar diferentes objetos (LESSA, 2010). Ao contrário dos estudos produzidos a partir da USP que priorizavam o exame das condições externas e das dinâmicas sociais e históricas, os pesquisadores vinculados ao grupo "mineiro/carioca" passaram a enfatizar os traços "internos" dos padrões de comportamentos institucionais. Como exemplos estão: a tese de Wanderley Guilherme dos Santos, defendida em Stanford, sobre o peso do legislativo na crise de 1964; e a de Olavo Brasil de Lima Jr, defendida em Michigan ${ }^{3}$, sobre o papel das alianças eleitorais, o sistema partidário e a racionalidade política.

Esses autores, apesar de realizarem análises distintas, centraram suas investigações nos impactos das dimensões institucionais e legais, orientados

2 A Fundação Ford foi uma das mais importantes financiadoras da expansão e implantação de uma Ciência Política estadunidense no Brasil. Por meio da concessão de bolsas e do financiamento de pesquisa, a Fundação foi peça-chave na consolidação do projeto norteamericano de formação de elites intelectuais na América Latina. A primeira instituição brasileira a receber recursos foi o Departamento de Ciência Política da UFMG, em 1967, e a segunda foi o IUPERJ, em 1969 (FORJAZ, 1997).

3 Os trabalhos produzidos pelo chamado "grupo de Michigan" constituem o paradigma dominante da ciência política americana sobre comportamento político. 
pela preocupação com a experiência do "autoritarismo" e com a "ausência de democracia” na política brasileira (LESSA, 2010). Nessa direção, o IUPERJ e os chamados "iuperjianos" passaram a ocupar uma posição de liderança intelectual nos principais espaços de produção, como se observa na primeira fase do grupo de trabalho "Elites Políticas", com a coordenação de Eli Diniz, por quatro anos e, posteriormente, de Renato Lessa, nos últimos três anos.

Levando em consideração não só os vínculos institucionais dos coordenadores - que, como vimos acima, apresentam uma forte concentração dos “iuperjianos" - mas também dos debatedores, apresentadores e as próprias características dos principais temas abordados, podemos perceber que a estrutura do GT reflete os efeitos dessa polarização.

Quadro 1: Distribuição dos Debatedores e Apresentadores por Instituição

\begin{tabular}{|l|r|r|r|r|r|r|c|}
\hline & IUPERJ & UFF & UFMG & UFRJ & \multicolumn{1}{c|}{ USP } & \multicolumn{1}{c|}{ FGV } & Outras Universidades \\
\hline Debatedores & $41,0 \%$ & $17,9 \%$ & $2,6 \%$ & ---- & $5,1 \%$ & $15,4 \%$ & $18 \%$ \\
\hline Apresentadores & $15,0 \%$ & $15,0 \%$ & $6,2 \%$ & $1,7 \%$ & $7,9 \%$ & $18 \%$ & $35 \%$ \\
\hline
\end{tabular}

O quadro acima demonstra, no caso dos debatedores, uma forte presença do IUPERJ, seguido da UFF, reforçando o predomínio "do modelo iuperjiano” na definição das problemáticas e na forma de conduzir e tratar a reflexão sobre o objeto. Já para os apresentadores, a polarização entre Rio de Janeiro/ Minas Gerais versus São Paulo é mais intensa, compondo 65\% daqueles que tiveram seus textos discutidos e analisados pelos coordenadores e debatedores. Tal polarização também se reflete nos espaços de formação da titulação mais alta. Do conjunto dos apresentadores, debatedores e coordenadores, $53 \%$ se formaram na USP e no IUPERJ e 30\% realizaram seu doutorado fora do país, com destaque, de um lado, para as universidades estadunidenses (Michigan/Stanford) e, de outro, para as universidades francesas e inglesas (Glasgow/Oxford/École de Hautes Études/Paris I).

Nesse sentido, pode-se dizer que há uma forte endogenia entre essas duas universidades, uma vez que, devido à estrutura do sistema de pós-graduação brasileiro nesse contexto, grande parte da produção se concentrava entre esses dois grandes polos numa circulação entre eles. Uma das principais consequências disso é a formação de redes de pesquisadores endógenas. Isso se manifesta no GT por meio das relações de orientação dos debatedores convidados e dos trabalhos selecionados para apresentação. Exemplifica isso o fato de que a maioria dos apresentadores foi orientada por um dos coordena- 
dores e/ou debatedores, ao mesmo em que muitos dos debatedores ou foram orientados por um dos coordenadores ou possuem vínculos institucionais com algum deles.

O exame das temáticas permitiu identificar que, no primeiro período do GT (1979-1996), foram priorizados os estudos das elites políticas e das elites econômicas e empresariais. Do total de estudos realizados durante todo o período de existência do GT, as primeiras representam 29,9\% e as segundas $12,5 \%$. Já no tocante ao total de estudos realizados sobre as elites políticas, $55,8 \%$ correspondem ao primeiro período e no caso das elites econômicas e empresariais esse percentual fica em 63,6\%. A predominância destes dois tipos de elites está relacionada aos investimentos acadêmicos dos dois principais coordenadores do GT, Renato Lessa e Eli Diniz, os quais posteriormente passam a se dedicar a dois novos Grupos de Trabalhos na ANPOCS: o de instituições políticas e o de empresariado. O privilégio ao "plano institucional” está diretamente associado à ênfase nas variáveis ou fatores políticos na explicação destas temáticas principais. As abordagens tinham como base "fatores estritamente internalistas", enfatizando tanto as interações e dimensões institucionais (ação do Estado, padrões de interações no legislativo, processos de intermediação de interesses etc.) quanto a racionalidade de suas práticas internas (processos decisórios, papel do sistema partidário, alianças eleitorais, sistema de representação etc.).

Desse modo, esse primeiro momento da produção acadêmica sobre elites (1979-1996) pode ser caracterizado, inicialmente, pelo confronto institucional entre duas principais "escolas": a de sociologia política da USP ("uspianos”), que tinha uma clara orientação "francesa”, e a "ciência política” feita na UFMG e no IUPERJ (os “iuperjianos”), de orientação norte-americana. Para fazer frente ao domínio institucional até então da escola sociológica da USP, a importação do modelo comportamentalista norte-americano se tornou um dos recursos importantes para a defesa e afirmação da ciência política como área especializada e institucionalizada de investigação no âmbito nacional e como a principal área na coordenação e na definição das temáticas e dos trabalhos apresentados no GT.

É interessante observar que essa orientação “comportamentalista” não implicou uma recusa da história enquanto material e evidência empírica, tal como ocorreu nos EUA, uma vez que, no caso brasileiro, muitos continuaram utilizando evidências históricas como base de sua explicação. A 
principal diferença com o que se fazia na escola sociológica da USP é que, nesta nova orientação, a história não é o fator explicativo, trazendo apenas evidências empíricas que fundamentam suas explicações "internalistas" e “institucionalistas" (FORJAZ, 1997; LESSA, 2010). Em suma, trata-se de um uso fortemente empirista, voltado à preocupação com a "autenticidade" e com a explicação da problemática e do dilema nacional, e não como fornecendo interpretações e explicações "históricas”. Daí decorre a ruptura com o marxismo e a escola sociológica.

Em consonância com isso, a preocupação central da ciência política direciona-se para a compreensão da experiência "autoritária” e das "fragilidades" de nossas instituições políticas e nossa democracia. Para isso, a abordagem "institucionalista" constitui uma alternativa às análises anteriores da política. Nessa lógica, uma série de temas que enfatizavam as dinâmicas políticas históricas, como aqueles da "sociologia política" que examinavam o fenômeno do "coronelismo", do "mandonismo" etc., foi classificada como historicamente datada e ultrapassada.

Como se pode ver, tanto a USP quanto o IUPERJ construíram uma tradição intelectual fundada numa relação de conformidade com os centros dominantes produtores de teoria. O que se observa, portanto, com esse material, é que se trata de dois centros universitários regionais de produção das ciências sociais que, mediante vínculos com diferentes centros de produção dominante no cenário internacional, disputavam internamente a autenticidade na interpretação e explicação das dinâmicas e problemas nacionais: autoritarismo, coronelismo, elites políticas, partidos políticos. Nessa relação, todo o conhecimento anterior produzido em solo nacional foi considerado não científico e ensaístico demais, sendo simplesmente classificado como “pensamento social”. A retomada do GT a partir de meados dos anos 2000 não foi muito diferente, posto que também não ocorreu com base no confronto, crítica ou diálogo com os pesquisadores, as investigações e a ampla produção tanto da "sociologia política” quanto do próprio do GT no período anterior. Antes disso, foi novamente a importação de teorias, problemáticas e modelos externos, que esteve na base dos principais confrontos e polarizações. 


\section{Rumo a Novas "Guinadas” Teóricas}

A fase seguinte, que se inicia nos anos 2000 e se caracteriza pela retomada do GT em 2007, apresenta algumas continuidades na medida em que novamente veremos em torno do GT o confronto entre uma "sociologia política” e uma "ciência política”. No entanto, observam-se também algumas mudanças. Os "institucionalistas” assumem um caráter mais "quantitativista”, enquanto a "sociologia política" volta-se para uma orientação marcadamente "bourdieusiana". Associada a estas mudanças de orientações, encontra-se uma maior diversificação institucional e regional no que diz respeito à universidade de origem dos coordenadores, debatedores e apresentadores. Todavia, esta continuidade em termos da polarização entre as principais orientações em jogo no estudo das elites não teve como base o diálogo, confronto ou mesmo ruptura com as abordagens e produções anteriores. Ainda que alguns coordenadores dessa nova fase tenham sido apresentadores ou orientandos de debatedores do período anterior, é novamente a recorrência a escolas, autores e abordagens externas para se sobrepor nas disputas internas que fundamenta a renovação em ambas as orientações. Por isso, faz sentido falar desse período como uma nova "guinada" teórica.

De um lado, os defensores de uma "ciência política” institucionalista se voltam para uma abordagem individualista em termos metodológicos, centrando-se nos mecanismos informais e nas metodologias "quantitativistas" oferecidas, inicialmente, pelos cursos de metodologia do IUPERJ e do departamento de Ciência Política da UFMG, podendo também ser chamados de "institucionalistas quantitativistas". São exemplos disso os trabalhos de Codato e Perissinotto (ambos orientandos de um dos apresentadores e debatedores do GT anterior) e que se voltam para a investigação dos condicionantes objetivos dos eleitos por meio dos testes de variáveis, tais como: profissão, sexo, cor, classe, partidos (CODATO; CERVI; PERISSINOTTO, 2013; BOLOGNESI; PERISSINOTTO; CODATO, 2016).

Estimulados por questões como "quem se torna prefeito", "quem se elege”, “o que afasta os negros e as mulheres da política”, estes estudos tomam o recrutamento político como uma relação entre variáveis, através das quais podemos observar as associações "fortes" ou "fracas". Outro exemplo nessa mesma linha são os estudos sobre os partidos políticos que enfatizam o “problema da seleção de candidatos”, buscando responder a questões como: 
"Quem pode ser eleito? Quem escolhe? Quem é selecionado? Quais as consequências do recrutamento?” (BRAGA; BOLOGNESI, 2013). A preocupação aqui está centrada nas dinâmicas operacionais dos partidos políticos com base no exame de estatutos, normas internas e programas, valores culturais e normas sociais referentes aos candidatos apropriados, tipos de experiências e conhecimentos adequados, modelando a oferta de candidatos, oferecendo redes sociais, treinamentos, habilidades cívicas e experiência organizacional (NORRIS, 2013). Os resultados obtidos, em geral, estão quase sempre baseados em questionários e/ou entrevistas com candidatos ou eleitos. Nesse sentido, Bolognesi (2013) mostra, com base em survey com candidatos, como operam os partidos ao formarem a lista de candidatos a deputado federal, concluindo que, uma vez que eles tenham sido selecionados por filiados, delegados, líderes ou líder único, podemos demarcar nítidas diferenças entre eles quanto à estrutura e à dinâmica prática do processo de seleção de candidatos nas organizações partidárias.

Do outro lado, estão aqueles que se vinculam a uma "sociologia política” com base nos trabalhos de Bourdieu e sua equipe, podendo também ser designados como "bourdieusianos". Diferentemente da abordagem anterior, trata-se, nesse caso, de priorizar a investigação dos processos de recrutamento e seleção das elites em diferentes esferas. Aqui a ênfase está nas relações objetivas entre as propriedades e trajetórias sociais que aproximam ou opõem os agentes, no estado das relações de forças entre as estruturas de recursos e de capitais mobilizados, bem como nos princípios legítimos de dominação em luta para sua imposição (CANEDO, 2002; 2011; CORADINI, 2008; MICELI, 1988; 2001). Do ponto de vista metodológico, trata-se de apreender, com base em informações biográficas diversificadas sobre os indivíduos, as propriedades sociais e os deslocamentos dos dirigentes no espaço social e político e de articulá-los com mudanças e transformações diacrônicas.

As duas primeiras edições desta segunda fase, de 2007 até 2009, foram coordenadas por Renato Perissinotto e Miguel Serna, com o título "Elites e Instituições Políticas”, numa associação entre Universidade Federal do Paraná e Universidad de La Republica del Uruguay. É, sobretudo, a partir de 2010 que se pode observar uma alteração mais significativa no tratamento do objeto, como também nos vínculos institucionais dos coordenadores, passando a coordenação de 2010 até 2012 para Ernesto Seidl e Mário Grynszpan, 
numa parceria entre a Universidade Federal de Sergipe e a Fundação Getúlio Vargas. Com esse novo grupo, nova orientação temática e teórica foram introduzidas, o que pode ser observado na mudança do próprio título do GT, que passou a se chamar "Grupos Dirigentes e Estruturas de Poder". Entre os anos 2013 e 2015, o GT foi proposto com base numa parceira entre os dois grupos, representado por Ernesto Seidl e Adriano Codato, este último da Universidade Federal do Paraná. A necessidade de articulação entre os dois grupos conduziu novamente a reformulações na denominação do GT, que então passou a se denominar: "Elites e Espaços de Poder".

Nesse sentido, cabe observar que, apesar desta alternância nas coordenações do GT a partir de meados dos anos 2000, a renovação e o desenvolvimento dos estudos sobre "elites" foram marcados pela concorrência entre estas duas principais orientações: de um lado, os "institucionalistas quantitativistas" que coordenaram sozinhos a primeira edição, e, do outro, os "bourdieusianos" que também estiveram sozinhos à frente da segunda coordenação. Diferente das anteriores, a terceira coordenação se caracterizou pela parceria entre elas. Sendo assim, pode-se dizer que até 2015 o trabalho de coordenação do GT foi igualmente dividido entre estas duas principais orientações ${ }^{4}$.

Tais perspectivas passaram a dominar a temática "elites” e a concentrar a produção acadêmica sobre o tema a partir do GT, conduzindo à emergência de determinados objetos analíticos em detrimento de outros. Uma análise feita a respeito das temáticas priorizadas nos trabalhos apresentados permitiu identificar que, apesar de ainda existir certa concentração em estudos "institucionalistas" sobre elites políticas e governantes, com 48,2\% dos trabalhos apresentados no GT, representada pelos estudos sobre deputados, senadores, governadores, vereadores, há, por outro lado, uma grande diversificação das temáticas e dos tipos de elites tomados como tema de investigação pelas ciências sociais brasileiras. Além de se destacarem os vários tipos de elites (eclesiásticas, militares, intelectuais, jurídicas, econômicas, burocráticas etc.), observa-se também a predominância do exame das carreiras, dos padrões de recrutamento e da composição social como objetos de investigação privilegiados. De certo modo, esta diversificação temática está associada

4 A título de informação, cabe salientar que, em 2016, não houve Seminário Temático (que geralmente constitui uma prévia do GT), mas, em 2017, a quarta coordenação do GT está novamente nas mãos dos "bourdieusianos", numa parceria entre UFMA e UFSCAR. 
à entrada do grupo "bourdieusiano” na coordenação do GT a partir de 2010.

Enquanto os trabalhos apresentados no período coordenado pelos "institucionalistas quantitativistas" estavam associados ao estudo dos eleitos, dos quadros dirigentes e dos governantes, os do período de coordenação dos "bourdieusianos" se revelaram mais diversificados, abrangendo uma população mais ampla como alvo de estudos de elites. Sem dúvida, o segundo grupo contribuiu para uma renovação e expansão dos estudos, sobretudo a partir dos anos de 2010, momento em que se observa um aumento do interesse no GT por diferentes tipos de elites: das políticas às sindicais, das profissionais e culturais às militantes etc. Este novo movimento contribuiu para integrar diferentes níveis e métodos de análise, ampliando as possibilidades analíticas e empíricas e envolvendo desde a análise histórica e uso de documentos até entrevista e análise biográfica. O exame dos mecanismos de seleção, das dinâmicas de recrutamento e da estrutura de capitais, antes ignorados, conduziu a um novo eixo de investigação com uma abrangência empírica maior. Percebe-se, então, que o reflexo da problemática bourdieusiana traduziu-se em estudos sobre a relação entre as trajetórias individuais, os princípios de dominação e a estrutura de capitais.

Este confronto entre "institucionalistas quantitativistas" e "bourdieusianos" no estudo de elites se manifesta de forma característica quando se examinam as universidades de origem, titulação e formações acadêmicas dos apresentadores de trabalho. A grande predominância $(61,8 \%)$ é de professores universitários, seguidos de mestrandos $(26,4 \%)$ e doutorandos $(11,8 \%)$. No que diz respeito à titulação, observa-se doutores, em primeiro, com $48,2 \%$ pesquisadores ainda em fase de qualificação, realizando mestrado (35,5\%), mestres com 12,7\%, e pós-doutores com 3,6\%. Apesar dos coordenadores do GT estarem vinculados a universidades situadas em diferentes regiões do país, ainda há forte predominância dos trabalhos do Sul $(26,4 \%)$ e do Sudeste $(39,1 \%)$, em todos os períodos, seguidos do Nordeste $(18,2 \%)$, Norte $(8,2 \%)$, estrangeiros $(4,5 \%)$ e Centro-oeste $(3,6 \%)$. É importante compreender também que as universidades que mais se destacam na produção do tema são, em primeiro lugar, a UFPR; em segundo, a UFSCAR; em terceiro, a UFRGS e a UFS; em quarto, a UFMA; e, em quinto, UFPA. A circulação de trabalhos do Nordeste está concentrada na UFS e UFMA, universidades estas de coordenadores e debatedores do GT cuja formação universitária transcorreu em universidade do Sul. Além disso, a apresen- 
tação de trabalhos oriundos do Nordeste aparece diretamente relacionada a vínculos estabelecidos com os coordenadores do GT. Já as universidades do Sul e Sudeste apresentam uma projeção maior, mantendo o vínculo com organizadores e debatedores do GT, mas ampliando para outros espaços acadêmicos, como UNESP, UNIFESP, UNIMONTE.

A estas diferenças em termos de universidades de origem e de titulação, corresponde uma clara distinção em termos das áreas de formação. A principal diferença está entre ciência política com 50,44\% do total de trabalhos apresentados e sociologia/ciências sociais com 36,12\%. Em terceiro lugar está a área de antropologia com 6,19\%. Ciências econômicas e direito têm respectivamente $1,77 \%$, o que corresponde a duas apresentações para cada área durante todo o período. Já educação, história, jornalismo, psicologia social e relações internacionais aparecem cada uma com apenas uma apresentação no decorrer do período analisado. Tal diferença de área reflete, por um lado, a grande predominância da ciência política no estudo de elites e, por outro, o progressivo investimento da sociologia política em relação a essa temática.

Esta oposição entre as principais áreas está também estreitamente ligada ao confronto entre "institucionalistas quantitativistas" e "bourdieusianos" em torno do GT, uma vez que a primeira orientação tem sido amplamente predominante na ciência política, enquanto que a "sociologia política" (também chamada sociologia do poder e das elites) está muito mais próxima dos "bourdieusianos" Isso fica mais claro quando se observa que é justamente durante a primeira coordenação que há uma grande predominância de trabalhos da área de ciência política: se do total de trabalhos apresentados durante a primeira coordenação, esse percentual é de 57,14\%, durante a terceira, ele cai para $38,71 \%$. Já no caso da sociologia ocorre um pequeno aumento, passando de 26,19\%, durante a primeira coordenação, para 30\%, durante a segunda, e $29,03 \%$, durante a terceira.

Acrescente-se a isso que, paralelo a essa diminuição da área de ciência política em cada diferente período de realização do GT, há o aumento da participação de outras áreas de formação. Assim, enquanto que na primeira coordenação os trabalhos apresentados eram basicamente da área de ciência política e de sociologia, na segunda e terceira ampliaram-se a participação de apresentadores com formação em outras áreas, como antropologia, ciências econômicas, educação, jornalismo etc. Nesse sentido, pode-se dizer que, 
paralelamente à introdução da problemática "bourdieusana" e à ampliação deste grupo na coordenação do GT, houve uma maior diversificação dos tipos de objetos e perspectivas estudadas.

Diferentemente do período anterior, essa nova "guinada" teórica no estudo das elites esteve diretamente associada a uma maior diversificação institucional e regional da rede de pesquisadores vinculados a esse tipo de estudo. Ainda que a maioria dos "institucionalistas quantitativistas" esteja vinculada ao Programa de Sociologia Política da UFPR, no caso dos "bourdieusianos" a rede é bem mais diversificada com pesquisadores no Sul, no Sudeste e no Nordeste, não se podendo falar no domínio de uma instituição, como era no tempo da "sociologia política da USP”. Antes disso, há uma maior circulação de apresentadores, de debatedores e até mesmo de coordenadores de diferentes universidades do país.

Em parte, isto está associado a uma maior difusão de Bourdieu no Brasil como um todo (BORTOLUCI; JACKSON; PINHEIRO FILHO, 2015), enquanto que a ciência política "institucionalista quantitativista" ainda parece concentrada nos pesquisadores que tiveram uma formação nos cursos de metodologia do IUPERJ e do Departamento de Ciência Política da UFMG. Por outro lado, isso é resultado também de uma maior expansão de diversificação do sistema de pós-graduação no Brasil nos anos 2000, possibilitando uma maior circulação da rede de pesquisadores cuja formação transcorreu no Sul e Sudeste para diferentes regiões do país.

Muito semelhante ao que ocorreu no período anterior, observamos que essa ampliação da problemática e diversificação da rede de pesquisadores que pesquisam o tema não estiveram associadas a um maior diálogo ou confronto com a produção anterior, tanto dos trabalhos da sociologia política anteriores à formação do primeiro GT quanto das próprias abordagens e produções de tal GT. Pelo contrário, a longa bibliografia produzida pela literatura brasileira na área da ciência política e da sociologia política não é mobilizada nessa segunda fase do grupo de trabalho. É justamente quando examinamos a bibliografia mobilizada pelo conjunto dos trabalhos apresentados no período de 2007 em diante que percebemos de forma clara o quanto esta nova "guinada” negligencia a produção brasileira anterior sobre o tema. 


\section{Usos e Abusos das Referências Bibliográficas}

Como se sabe, as escolhas bibliográficas não só exprimem os compromissos teóricos e metodológicos dos autores e revelam suas filiações, como também nos permitem compreender as redes a que estão vinculados. Quanto a isso, o exame dos principais autores e obras citadas pelo conjunto dos trabalhos apresentados no GT revela uma característica que, como já salientamos, está também presente no conjunto da produção acadêmica das ciências sociais brasileira: o amplo conhecimento e a forte referência a teorias e abordagens produzidas na Europa e EUA e a ausência de discussão e confronto com a produção acadêmica nacional anterior (COSTA, 2010).

Nesse sentido, observa-se que, do conjunto da bibliografia utilizada, $54,8 \%$ são autores brasileiros e $45,2 \%$ são estrangeiros ${ }^{5}$. Os estrangeiros que mais aparecem são franceses e estadunidenses, com 15\% cada. Os demais se dividem entre britânicos, alemães, italianos e latino-americanos. Consequentemente, as regiões de produção das obras citadas se dividem entre, de um lado, América Latina, em especial o Brasil, com 56,8\%, e, de outro, a Europa (27\%) e a América do Norte (15,9\%).

Todavia, um dos aspectos que merece maior reflexão é o fato de que a forte vinculação da produção nacional sobre elites com a teoria social internacional não ocorre a partir de um confronto com a extensa produção brasileira anterior relacionada ao estudo dos grupos dirigentes no país. Pelo contrário, como já observamos antes, tal como aconteceu nas "guinadas" teóricas anteriores, a longa bibliografia produzida pela literatura brasileira na área da ciência política e da sociologia política não é mobilizada nessa segunda fase do GT. Isso fica evidente quando se examinam os autores mais recorrentes nos trabalhos apresentados. Tal exame revela que Bourdieu é de longe o autor mais citado, seguido por alguns dos principais tradutores e intérpretes de sua aplicação no Brasil, indicando uma clara predominância dos que se aproximam da problemática "bourdieusiana” no estudo dos grupos dirigentes.

5 Foram cadastrados 1.739 diferentes autores citados pela bibliografia e 2.320 obras citadas. 
Quadro: Autores mais citados por nacionalidade

\begin{tabular}{lcc}
\hline Autor & Vezes que foi citado & Nacionalidade \\
\hline BOURDIEU P. & 97 & Francês \\
CORADINI O. L. & 33 & Brasileiro \\
MICELI S. & 26 & Brasileiro \\
GRUN R. & 24 & Brasileiro \\
\hline
\end{tabular}

Quando cruzamos os autores citados na bibliografia com as universidades de origem dos proponentes dos artigos apresentados no GT, podemos perceber que Bourdieu é citado em, praticamente, todas as universidades, com destaque para: UFSCAR, UFMA, UFRGS, UFS, UNICAMP, USP, universidades com forte presença de autores do grupo "bourdieusiano". Isso indica, por um lado, o impacto da produção do autor nas ciências sociais brasileiras. Sua citação nessas universidades está diretamente associada ao impacto da obra de Pierre Bourdieu no Brasil, no que diz respeito especificamente à temática das elites. Por outro lado, indica também a forte coesão da rede de pesquisadores "bourdieusianos", pois ainda que seja bastante diversificada, uma vez que faz parte dela pesquisadores vinculados a instituições universitárias e programas de pós-graduação localizados em diferentes regiões do país, tal rede se desenvolveu a partir dos principais representantes da aplicação de Bourdieu no Brasil e tem como base a intensa citação intragrupo.

Nesse sentido, destacam-se os estudos de Sérgio Miceli (1988; 2001) sobre os intelectuais e as elites dirigentes, realizados na USP. Os trabalhos que resultaram desta orientação se voltaram para a compreensão dos capitais acumulados e das estratégias de consagração em diferentes setores: empresários, gerentes, arquitetos, indústria cultural, jornalistas, dentre outros (GRUN, 1995). Merecem destaque também os estudos de Canedo (2002; 2011), de Almeida (2009) e os trabalhos produzidos a partir da Unicamp, os quais deram ênfase aos herdeiros, às estratégias de reprodução familiar e suas consequências nas carreiras políticas. Ganharam espaço também os estudos sobre o papel dos títulos escolares na consagração das elites. E, por fim, mas não menos importante, destacam-se os estudos vinculados aos trabalhos e à orientação de Coradini na UFRGS. Esta última orientação resultou em investigações sobre elites militantes, políticas, militares, intelectuais, profissionais e religiosas, cuja problemática central voltou-se para o processo de acúmulo e reconversão de recursos (CORADINI, 2008; ANJOS, 2006; 
OLIVEIRA, 2005; 2008a; 2008b; PETRACA, 2007a; 2007b; 2008a; 2008b; GRILL, 2008; 2013; REIS, 2015; REIS; GRILL, 2014; ENGELMAN, 2004; SEIDL, 2004; SEIDL; GRILL, 2013).

Essa forte presença de Bourdieu e da rede de pesquisadores "bourdieusianos" entre as principais referências dos trabalhos apresentados no GT é reforçada pelo fato de que das cinco obras mais citadas duas são dele: "O Poder Simbólico", que aparece como a obra mais citada, e "La Noblesse d’État", que aparece como a quarta obra mais citada. No tocante à participação de referências estrangeiras, cabe destaque ainda o fato de que a terceira obra mais citada é também de um francês: “Os Intelectuais e a Política no Brasil”, de Daniel Pécaut. Entre os brasileiros, “A Construção da Ordem”, de José Murilo de Carvalho, aparece como a mais citada, juntamente com Bourdieu, e duas obras de Leôncio Martins Rodrigues: "Partidos Políticos, Ideologia e Composição Social", que aparece como a segunda obra mais citada, e "Mudança na Classe Política Brasileira”, como a quinta obra.

Diferente do quadro que se apresentou pela análise dos autores mais citados, quando estão em jogo as principais obras de referência para o estudo da temática, a presença de três trabalhos de dois autores brasileiros chama a atenção. Ela confirma o recorrente esquecimento e ausência de confronto tanto com a ampla produção nacional anterior do GT quanto com os estudos clássicos da sociologia política brasileira sobre as elites nacionais: das obras citadas apenas uma é de autor que teve passagem como apresentador no primeiro período do GT, enquanto que as outras duas são de um autor sem vínculo anterior com o GT, ainda que um de seus orientandos tenha sido um dos coordenadores. Nenhum dos trabalhos clássicos sobre as elites brasileiras figura entre as obras mais citadas, confirmando que a ausência de confronto com a produção nacional constitui também uma das características principais desta renovação e "guinada teórica" da produção brasileira no estudo dos grupos dirigentes.

Como já deixamos claro, a recorrente tensão entre "autenticidade" e "imitação”, associada à crescente fragmentação da produção intelectual brasilei-

6 Vale a pena observar que a obra mais citada de Bourdieu está longe de ser um dos seus estudos considerados clássicos para o estudo dos grupos dirigentes (como La Noblesse D’État), mas uma obra de divulgação geral de seu pensamento. Para uma análise da relação entre essa forma de apreensão e difusão do pensamento deste autor e as condições institucionais, de concorrência e de exercício das ciências sociais no Brasil, ver Coradini (1996). 
ra entre redes e grupos de pesquisadores diversificados e ao uso estratégico para distinção interna das teorias dominantes no cenário internacional, não constitui uma particularidade da produção intelectual sobre elites e grupos dirigentes. Todavia, tais aspectos nos permitem entender a negligência em relação às investigações sobre as condições e as dinâmicas de formação e de recomposição das elites brasileiras, através das análises das "parentelas”, do "coronelismo", da "família extensa", do "mandonismo", das "relações pessoais", entre outras. Em função disso, são recorrentes algumas dificuldades na compreensão de situações como a brasileira, apesar das constantes renovações teóricas e metodológicas, de uma grande diversificação da problemática envolvida na investigação dos grupos dirigentes através desses estudos (PETRARCA; OLIVEIRA, 2017) e das oposições institucionais entre "ciência política" e "sociologia política”, entre "institucionalistas quantativistas" e "bourdesianos". O que chama a atenção nesta análise da recente produção intelectual sobre elites é que os usos das teorias reconhecidas no cenário internacional deixam de ser mobilizados, como no período anterior, para a busca de "autenticidade" das problemáticas e dilemas nacionais. Trata-se, agora, de uma busca pelo reconhecimento da interpretação capaz de melhor traduzir o legítimo uso de autores e escolas dos centros dominantes nas disputas internas. Enfim, passamos então de uma situação em que a busca de "autenticidade" para a luta interna dá lugar à luta interna pelo reconhecimento dos intérpretes autorizados das escolas e autores consagrados internacionalmente.

\section{Considerações Finais}

A análise da produção brasileira sobre "elites" e "grupos dirigentes” ao longo de quase três décadas permitiu compreender a formação deste campo de estudos e a construção deste objeto nas ciências sociais brasileira. Apesar da longínqua oposição entre "ciência política" e "sociologia política" no estudo dos grupos dirigentes brasileiros, um dos aspectos que merece aprofundamento e reflexão é a continuidade de uma tradição intelectual que é feita de rupturas, de mudanças de orientações e de inovações teóricas e conceituais que têm como base uma "ausência de consciência da continuidade intelectual, do pertencimento a uma tradição” (BRANDÃO, 2010, p. 372). Frequentemente, nos vemos diante de formulações que começam "vá- 
rias vezes do zero, ignorando aqueles que antes deles tentaram os mesmos diagnósticos e as mesmas soluções" e que, por vezes, "adotaram perspectivas 'metodológicas' semelhantes” (Id. Ibid., p. 372). Diretamente vinculada a isso, está a recorrente tendência de importação de abordagens conceituais, de problemáticas e de interpretações eurocêntricas como fundamento dos debates e confrontos. Semelhante ao que tem acontecido em outras áreas de investigação (GOIRAND, 2010, p. 460; OLIVEIRA, 2013), isso tem como base a inserção e circulação de estudantes e pesquisadores entre grupos e redes de pesquisa vinculadas a universidades e instituições dos EUA e da Europa e contribui para que conceitos consagrados ou problematizados pela produção acadêmica internacional sejam aplicados sem maiores questionamentos a respeito de sua pertinência para a situação brasileira e sem confronto com a produção nacional sobre o tema.

No decorrer da longa história do GT Elites, observa-se a existência de 4 grupos com orientações teóricas distintas, cada qual buscando o controle da temática e mobilizando para isso recorrentemente um conjunto de abordagens consagradas no âmbito internacional, sem confrontá-las com as perspectivas e a produção anteriormente utilizadas pelas ciências sociais brasileiras. Por isso, apesar das recorrentes oposições e mesmo confronto entre estes diferentes grupos, pode-se dizer que, de maneira geral, eles se caracterizam pela importação de modelos teóricos e conceituais dos países hegemônicos como signo de distinção interna e pela carência de discussão e confronto destas abordagens com as que já foram adotadas por cientistas sociais brasileiros, o que conduz naturalmente ao abandono de autores cuja produção é marcada pela extensa pesquisa empírica sobre a dinâmica nacional. Esta falta de diálogo com os pares nacionais produz, por um lado, uma diversidade e pluralidade teórica, conceitual e metodológica, mas, por outro, impede o diálogo com a produção nacional e a criação de uma tradição que possa promover o acúmulo de conhecimento, de problemáticas e de objetos de análise que concorram para consolidação desta área de pesquisa no Brasil.

Por isso, as recorrentes inovações e renovações teóricas da produção intelectual brasileira foram ao longo do artigo caracterizadas como "guinadas teóricas”, no sentido de que têm sido fortemente baseadas na importação de escolas, teorias e autores europeus e estadunidenses e no abandono e ausência de confronto e diálogo com a produção intelectual nacional, estando 
voltadas exclusivamente à rearticulação institucional das redes de pesquisadores vinculados a determinado tema ou disciplina. A cada movimento de renovação teórica, a sociologia brasileira também renova e reforça sua posição subalterna em relação à sociologia mundial: às teorias e aos conceitos vindos de fora, produzidos pelos países que ocupam posição hegemônica no cenário internacional. Sem dúvida, tal prática não constitui um traço particular ou inerente à produção brasileira, uma vez que está na base da divisão do trabalho que desde o início caracterizou a posição colonialista das ciências sociais ocidentais (COSTA, 2010).

Dessa forma, ao aplicar de forma automática tais conceitos e problemáticas à situação brasileira, sem o devido questionamento das bases empíricas que os fundamentam e de sua pretensa universalidade, os cientistas sociais brasileiros acabam dando continuidade a esta posição de simples reprodutores de modelos importados (teóricos e conceituais), ficando à margem do debate, da crítica da universalidade de tais formulações e de sua possibilidade de dar conta das múltiplas e distintas formas de configuração da "modernidade". Um dos principais efeitos disso é a recorrente aplicação de teorias "pouco compatíveis com a modernidade brasileira" (COSTA, 2010, p. 45) e a ausência de reflexão teórica e conceitual sobre a própria modernidade e sua relação com o Brasil no âmbito da sociologia brasileira e mundial.

Portanto, o GT Elites constitui um caso exemplar para a compreensão e demonstração dos efeitos da fragmentação nas dinâmicas de concorrência interna. Em condições concorrenciais marcadas pela diversificação das redes de pesquisadores, os cientistas sociais não hesitam em ativar como trunfos autores e escolas consagradas no espaço internacional, mobilizando para isso seu capital intelectual variado (recrutamento de novos membros, redes internacionais, ativação de instâncias de consagração, publicações etc.). Uma das consequências desta dinâmica é que ela ignora a existência de uma tradição de estudos, pesquisas e confrontos sobre o tema, produzindo intérpretes autorizados que lutam internamente pela melhor interpretação das escolas e autores consagrados internacionalmente.

Um dos constrangimentos que pesam sobre os cientistas sociais brasileiros é que a fragmentação, marcada pela forte concorrência interna para ocupar os espaços de consagração e legitimação das ciências sociais nacionais (como ANPOCS, GTs etc.), impediu a formação de "movimentos científicos/ 
intelectuais” capazes de produzir lideranças que disputem problemáticas e teorias no cenário internacional. Uma das consequências disso é a dificuldade de assumir uma postura crítica e propositiva diante das teorias e conceitos dominantes e de traduzir os problemas estudados em problemáticas e questões universais das ciências sociais, conduzindo à manutenção da reprodução do que já foi denominado por Maia e Caruso (2012) como a constante tensão entre "imitação" e "autenticidade".

\section{Referências bibliográficas}

ALMEIDA, Ana Maria A. (2009), Escola dos Dirigentes Paulistas. 1 ed. Belo Horizonte: Argvmentvm Editora.

ANJOS, José Carlos Gomes. (2006), Intelectuais, Literatura e Poder e Cabo Verde: lutas pela definição da identidade nacional. 1 ed. Porto Alegre: EDUFRGS.

BOLOGNESI, Bruno. (2013), A Seleção de Candidaturas no DEM, PMDB, PSDB e PT nas Eleições Legislativas Federais Brasileiras de 2010. Percepções dos candidatos sobre a formação das listas. Revista de Sociologia e Política, v. 21 , n. 46 , pp. $45-68$.

BOLOGNESI, Bruno; PERISSINOTTO, Renato; CODATO, Adriano. (2016), "Reclutamiento político en Brasil. Mujeres, negros y partidos en las elecciones federales de 2014”. Revista Mexicana de Ciencias Políticas y Sociales, v. 61, n. 226, pp. 183-212.

BORTOLUCI, José Henrique, JACKSON, Luiz C.; PINHEIRO FILHO, Fernando A. (2015), Contemporâneo clássico: a recepção de Pierre Bourdieu no Brasil. Lua Nova: Revista de Cultura e Política, n. 94, pp. 217-254.

BOURDIEU, Pierre. (2002), Les conditions sociales de la circulation internationale des idées. Actes de la Recherche en Sciences Sociales, v. 145, pp. 3-8.

BOURDIEU, Pierre; WACQUANT, Loïc J. D. (1998). "Sur les ruses de la raison impérialiste”. Actes de la Recherche en Sciences Sociales, v. 121, n. 1, pp. 109-118.

BRAGA, Maria do Socorro Sousa; BOLOGNESI, Bruno. (2013), "Dossiê Recrutamento Político e Seleção de Candidatos nas Democracias Contemporâneas”. Revista de Sociologia e Política, v. 21, n. 46, pp. 5-9.

BRANDÃO, Gildo Marçal. (2010), "Ideias e Argumentos para o Estudo da História das Idéias Políticas no Brasil”. In: MARTINS, Carlos Benedito; LESSA, Renato; FIGUEIREDO, Angelina Maria Cheibub. (Ed.). Horizontes das ciências sociais no Brasil. Ciência política. São Paulo: ANPOCS; Instituto Ciência Hoje; Discurso Editorial; Barcarolla. pp. 367-376. 
CANEDO, Letícia. (2002), "Herança na política ou como adquirir disposições e competências necessárias às funções de representação política (19451964)”. Pro-posições, v. 13, n. 3, pp. 169-198.

CANEDO, Letícia. (2011), "Um capital político multiplicado no trabalho genealógico”. Revista Pós Ciências Sociais, v. 8, n. 15, pp. 55-75.

CODATO, Adriano; PERISSINOTTO, Renato. (2008), “Apresentação: por um retorno à Sociologia das Elites”. Revista de Sociologia e Política, v. 16, pp. 7-15.

CODATO, Adriano; CERVI, Emerson; PERISSINOTTO, Renato. (2013), "Quem se elege prefeito no Brasil: condicionantes do sucesso eleitoral em 2012”. Cadernos ADENAUER, v. 2, pp. 61-84.

CORADINI, Odaci Luiz. (2008), As Elites como Objeto de Estudos. In: CORADINI, Odaci Luiz. Estudos de Grupos Dirigentes no Rio Grande do Sul. Porto Alegre: EDUFRGS. pp. 7-18.

CORADINI, Odaci Luiz. (1996), "O referencial teórico de Bourdieu e as condições para sua aprendizagem e utilização". Revista Veritas, v. 41, n. 162, pp. 207-220.

COSTA, Sérgio. (2010), “Teoria por Adição”. In: MARTINS, Carlos Benedito; MARTINS, Heloísa Helena Teixeira de Souza; BOTELHO, André. (Ed.). Horizontes das ciências sociais no Brasil. Sociologia. São Paulo: ANPOCS; Instituto Ciência Hoje; Discurso Editorial; Barcarolla. pp. 25-51.

ENGELMENN, Fabiano. (2004), Diversificação do espaço jurídico e lutas pela definição do direito no Rio Grande do Sul. Tese de Doutorado em Ciência Política. Porto Alegre: UFGRS.

FRICKEL, Scott; GROSS, Neil. (2005), "A General Theory of Scientific/Intellectual Movements”. American Sociological Review, v. 70, n. 2, pp. 204-32.

FORJAZ, Maria Cecilia Spina. (1997), "A emergência da Ciência Política acadêmica no Brasil: aspectos institucionais". Revista Brasileira de Ciências Sociais, v. 12, n. 35, online. Disponível em: http://www.scielo.br/scielo. php? script $=$ sci_arttext\&pid $=$ S0102-69091997000300007\&lng $=$ pt\&nrm $=\mathrm{i}$ so. Acesso em: $\overline{20}$ nov. 2018.

GOIRAND, Camille. (2010), "Penser Les Mouvements Sociaux d'Amérique Latine. Les approches des mobilisations depuis les anneés 1970”. Revue Française de Science Politique, v. 60, n. 3, pp. 445-466.

GRILL, Igor Gastal. (2008), "Heranças Políticas” no Rio Grande do Sul. 1 ed. São Luís: EDUFMA.

GRILL, Igor Gastal. (2013), “Especialização política: bases sociais, profissionalização e configurações de apoios”. In: SEIDL, Ernesto; GRILL, Igor Gastal. (org.). As Ciências Sociais e o Espaço da Política no Brasil. Rio de Janeiro: FGV. pp. 103-140. 
GRUN, Roberto. (1995), A Revolução dos Gerentes Brasileiros. 1 ed. São Carlos: EDUFSCAR.

GRYNZSPAN, Mario. (1996), “A Teoria das Elites e sua Genealogia Consagrada”. $B I B$, n. 41, 10. Semestre, pp. 35-83.

LESSA, Renato. (2010), “O Campo da Ciência Política no Brasil: uma aproximação construtivista”. In: MARTINS, Carlos Benedito; LESSA, Renato; FIGUEIREDO, Angelina Maria Cheibub. (ed.). Horizontes das ciências sociais no Brasil. Ciência política. São Paulo: ANPOCS; Instituto Ciência Hoje; Discurso Editorial; Barcarolla. pp. 13-49.

MAIA, João Marcelo Ehlert; CARUSO, Gabriela de Brito. (2012), "Uma Trajetória Intelectual Periférica: Hussein Alatas e a sociologia autônoma”. Perspectivas, v. 41, pp. 53-77.

MICELI, Sérgio. (1988), A elite eclesiástica brasileira. 1 ed. Rio de Janeiro: Bertrand Brasil.

MICELI, Sérgio. (2001), Intelectuais à Brasileira. 1 ed. São Paulo: Companhia das Letras.

NORRIS, Pippa. (2013), "Recrutamento Político". Revista de Sociologia e Política, v. 21, n. 46, pp. 11-32.

OLIVEIRA, Wilson José F. de. (2008a), "Engajamento Político, Competência e Elites Dirigentes do Movimento Ambientalista”. Revista de Sociologia e Política, v. 16, pp. 167-186.

OLIVEIRA, Wilson José F. de. (2008b), "Gênese e Redefinições do Militantismo Ambientalista no Brasil”. Dados, v. 51, pp. 751-777.

OLIVEIRA, Wilson José F. de. (2005), “Paixão pela Natureza”, Atuação Profissional e Participação na Defesa de Causas Ambientais no Rio Grande do Sul entre 1970 e início dos anos 2000. Tese de Doutorado em Antropologia Social. Porto Alegre: UFRGS.

OLIVEIRA, Wilson José F. de. (2013), "A Arte de Resistir às Palavras: inserção social, engajamento político e militância múltipla”. In: SEIDL, Ernesto; GRILL, Igor Gastal. (org.). As Ciências Sociais e o Espaço da Política no Brasil. Rio de Janeiro: FGV. pp. 141-178.

PETRARCA, Fernanda Rios. (2008a), "Carreira militante, inserção profissional e exercício do jornalismo no Rio Grande do Sul”. Política \& Sociedade, v. 7, pp. 311-329.

PETRARCA, Fernanda Rios. (2008b), "Competência Profissional, Recursos Políticos e Defesa do Jornalismo”. Sociedade e Cultura, v. 11, pp. 91-101.

PETRARCA, Fernanda Rios. (2007b), “Conflitos Profissionais e Usos do Título Acadêmico para o Exercício do Jornalismo no Rio Grande do Sul”. Teoria $\mathcal{E}$ Sociedade, v. 1, pp. 94-119. 
PETRARCA, Fernanda Rios. (2007a), O Jornalismo como Profissão: recursos sociais, titulação acadêmica e inserção profissional dos jornalistas no RS. Tese de Doutorado em Sociologia. Porto Alegre: UFRGS.

PETRARCA, Fernanda Rios; OLIVEIRA, Wilson José F. de. (2017), "Parentelas, grupos dirigentes e alianças políticas”. Política $\&$ Sociedade, v. 16, pp. 191-224.

REIS, Eliana Tavares dos. (2015), Trajetórias, espaços e repertórios de intervenção política: um estudo sobre os militantes que lutaram contra a ditadura no Rio Grande do Sul. 1 ed. Porto Alegre; São Luís: ZOUK; EDUFMA.

REIS, Eliana Tavares dos; GRILL, Igor Gastal. (org.). (2014), Estudos sobre elites políticas e culturais. 1 ed. São Luís: EDUFMA.

SAINT-MARTIN, Monique. (1988), “A propos d'une rencontre entre chercheurs [Sciences sociales et politique au Brésil]”. Actes de la recherche en sciences sociales 71, n. 1, pp. 129-34.

SEIDL, Ernesto; GRILL, Igor Gastal. (2013), As Ciências Sociais e os Espaços da Política no Brasil. 1 ed. Rio de Janeiro: FVG.

SEIDL, Ernesto. (2004), A elite eclesiástica no Rio Grande do Sul. Tese de Doutorado em Ciência Política. Porto Alegre: UFGRS. 


\title{
O Ensino de Ciências Sociais na Região Sul: Instituições e Pesquisadores
}

\author{
Amurabi Oliveira* \\ Willian Binsfeld * *
}

\section{RESUMO}

O tema do ensino de Sociologia tem ganhado cada vez mais espaço nas Ciências Sociais brasileiras, impulsionado principalmente pela reintrodução da Sociologia no currículo escolar a partir de 2008. Partindo do caso dos Programas de Pós-Graduação em Ciências Sociais e seus pesquisadores na região Sul do Brasil, buscamos analisar como que a temática do ensino se insere na agenda de pesquisa das Ciências Sociais. Destacam-se nesta pesquisa as trajetórias realizadas por estes agentes, que possibilitaram seu engajamento neste campo de pesquisa, o que inclui predominantemente o ensino de disciplinas ligadas à formação de professores, a organização de coletâneas sobre o tema e, recorrentemente, experiências anteriores com educação básica e com pesquisa na área de educação.

Palavras-chave: Ensino de Sociologia. Campo Acadêmico. Sociologia da Educação.

* Doutor em Sociologia pela UFPE, Professor do PPGSP/PPGE UFSC, Pesquisador do CNPq.

* * Graduando em Ciências Sociais UFSC, Bolsista de Iniciação Científica/CNPq. 


\begin{abstract}
THE TEACHING OF THE SOCIAL SCIENCES IN THE SOUTH REGION: INSTITUTIONS AND RESEARCHERS
\end{abstract}

The theme of teaching sociology has been gaining more and more space in the Brazilian social sciences, mainly by the reintroduction of sociology in the school curriculum since 2008. Starting from the case of the social sciences graduate programs and their researchers in the southern region of Brazil, we try to analyze how the thematic of teaching is inserted in the research agenda of the social sciences. In this research, the trajectory carried out by these agents, which made possible their engagement in this field of research, predominantly includes the teaching of disciplines related to teacher training, the organization of collections on this subject, and recurrent previous experiences in basic education and research in education.

Keywords: Teaching Sociology. Academic Field. Sociology of Education.

\title{
Introdução
}

Em 2018, faz dez anos que a Sociologia foi reintroduzida em nível nacional no Ensino Médio brasileiro ${ }^{1}$, o que é reflexo de um conjunto de ações articuladas a partir de entidades profissionais, associações científicas, universidades etc. Em que pese os retrocessos vivenciados em período mais recente - destacando-se a exclusão da obrigatoriedade desta disciplina a partir da chamada "Reforma do Ensino Médio"2 -, é inegável que nesta última década houve avanços significativos do debate acadêmico em torno do chamado "Ensino de Sociologia".

Pode-se observar a maturação das discussões acadêmicas nesta temática através de ações como: a) criação e consolidação do Grupo de Trabalho "Ensino de Sociologia” junto ao Congresso Brasileiro de Sociologia, cujas atividades vêm funcionando de forma regular desde 2005; b) advento do

1 Introdução realizada através da Lei $n^{\circ} 11.684 / 08$. Para um melhor exame do percurso dessa introdução no nível da legislação, vide o trabalho de Cravo Azevedo (2015).

2 Inicialmente estabelecida através da Medida Provisória $n^{\circ} 476$ de 2016, convertida na Lei $\mathrm{n}^{\mathrm{o}} 13.415 / 17$.

3 Como no caso brasileiro a formação de professores para o ensino desta disciplina se dá nos cursos de Ciências Sociais, englobando também uma formação em Antropologia e Ciência Política, além da Sociologia, utilizaremos neste texto os termos "ensino de Sociologia" e "ensino de Ciências Sociais", quando nos referirmos à educação básica, como sinônimos, inclusive por compreendermos que o ensino da disciplina Sociologia engloba os conhecimentos das Ciências Sociais. 
Encontro Nacional para o Ensino de Sociologia na Educação Básica, evento que vem ocorrendo de forma bianual desde 2009; c) fundação em 2012 da Associação Brasileira de Ensino de Ciências Sociais, com a criação em 2017 de um periódico específico para esta temática; d) criação de Grupos de Trabalho sobre Ensino também na Associação Brasileira de Antropologia e na Associação Brasileira de Ciência Política; e) criação do mestrado profissional em Ciências Sociais para o Ensino Médio junto à Fundação Joaquim Nabuco (FUNDAJ), e do ProfSocio ${ }^{4}$.

Constata-se, desse modo, que em um curto intervalo de tempo ocorreu um significativo avanço nas discussões, substanciado em ações efetivas, que também se refletem no incremento de publicações especializadas, especialmente através de dossiês temáticos e coletâneas, o que exploraremos mais adiante neste trabalho.

Ainda que esta seja uma tendência bastante ampla, que em algum grau envolve pesquisadores de diversas partes do país, tanto em nível de graduação quanto de pós-graduação, neste trabalho nos focaremos em como a temática do ensino se insere na agenda de pesquisa das Ciências Sociais na Região Sul do Brasil, observando este fenômeno a partir da pós-graduação em Ciências Sociais ${ }^{5}$, considerando tanto a dimensão das instituições quanto dos sujeitos.

O recorte geográfico circunscrevendo nossa amostra à Região Sul não é mero acaso, pois se trata da única região do país na qual o Ensino de Sociologia foi introduzido no Ensino Médio em todos os estados antes da obrigatoriedade nacional (OLIVEIRA, 2016). Ademais, trata-se de uma região que possui universidades que capitaneiam esta discussão em nível nacional, com destaque para a Universidade Estadual de Londrina (UEL), que fora a primeira a criar uma linha de pesquisa em "Ensino de Sociologia” junto ao Programa de Pós-Graduação em Ciências Sociais.

Reconhece-se ainda que, ao nos limitarmos a uma análise situada a partir dos Programas de Pós-Graduação em Ciências Sociais, não abarcaremos

4 Mestrado profissional na área de Ciências Sociais de caráter semipresencial em rede que inclui as seguintes instituições: FUNDAJ, Universidade Federal de Campina Grande (UFCG), Universidade Federal do Ceará (UFC), Universidade Federal do Vale do São Francisco (UNIVASF), Universidade do Vale do Acaraú (UVA), Universidade Estadual Paulista (UNESP - Marília), Universidade Estadual de Londrina (UEL), Universidade Estadual de Maringá (UEM), Universidade Federal do Paraná (UFPR).

5 Incluem-se aqui não apenas os programas que possuem essa denominação, como também os de Antropologia, Ciência Política, Sociologia e Sociologia Política. 
a discussão em sua totalidade, considerando-se tanto o fato de que há um significativo desenvolvimento de pesquisas que se estabelecem apenas em nível de graduação, quanto a existência de pesquisas sobre Ensino de Sociologia realizadas junto a Programas de Educação, como podemos verificar a partir de recentes balanços realizados (CAREGNATO; CORDEIRO, 2014; HANDFAS, 2017; BODART; CIGALES, 2017). Entretanto, interessa-nos aqui pensar como que esta questão se insere na agenda de pesquisa das Ciências Sociais brasileiras, que dentro dos processos de transformações do mundo acadêmico nas últimas décadas acaba por se centrar nos programas de pós-graduações disciplinares nesta área de conhecimento.

Utilizaremos como base de dados desta nossa investigação as plataformas Sucupira (https://sucupira.capes.gov.br/) e Lattes (http://lattes.cnpq.br/), para termos acesso aos dados dos programas e dos pesquisadores. Ao nível dos programas, buscaremos observar a existência de linhas de pesquisa que dialoguem com a temática da educação em geral e do ensino de Ciências Sociais em particular, almejando com isso verificar se o ensino de Sociologia possui um espaço institucional na agenda de pesquisa de tais programas. No que tange aos pesquisadores, através da análise do Lattes de todos os professores que lecionam nestes diversos programas, observaremos quatro indicadores, sendo que ao final faremos uma análise mais cuidadosa do perfil daqueles que apresentarem ao menos 3 destes, quais sejam: a) lecionar disciplinas específicas da licenciatura em Ciências Sociais; b) projetos de pesquisa e/ou extensão na área de ensino de Ciências Sociais; c) produção bibliográfica sobre esta temática na forma de artigos em periódicos, livros, coletâneas e capítulos de livro; d) orientação em nível de pós-graduação de pesquisas relacionadas a este tema.

Reconhecem-se os limites encontrados neste tipo de abordagem metodológica, todavia, compreendemos que os dados fornecidos por tais plataformas - consideradas as mais relevantes no processo de avaliação institucional da pós-graduação no Brasil - nos possibilitam uma aproximação de caráter descritivo e interpretativo do campo, produzindo uma análise relevante para a compreensão da dinâmica do ensino de Sociologia no Brasil bem como do perfil dos pesquisadores envolvidos neste debate, o que é um exercício ainda incipiente nos diversos estados da arte produzidos até aqui.

Em termos de teoria, dialogaremos diretamente com o arcabouço elaborado pelo sociólogo Pierre Bourdieu (1930-2002), para compreendermos 
tanto as disputas que se estabelecem dentro do campo acadêmico quanto o processo de construção das disposições sociais dos pesquisadores e seus engajamentos e estratégias.

Para uma melhor organização dos argumentos aqui apresentados, dividiremos este trabalho em mais cinco seções: a) na primeira, trataremos da Pós-Graduação Em Ciências Sociais no Sul do Brasil, apresentando o número de programas, data de criação, dando destaque para a existência de linhas de pesquisa sobre ensino e educação ou que dialoguem com estas; b) na segunda, realizaremos uma apresentação dos pesquisadores selecionados, buscando compreender as escolhas realizadas no campo científico a partir de suas trajetórias em termos de atuação profissional e formação acadêmica; c) posteriormente, analisaremos a produção intelectual destes docentes que versa sobre o tema do ensino, buscando entender como ela está organizada e como se insere na lógica das disputas do campo; d) também nos interessa pensar os processos de orientação, analisando a existência de trabalhos em nível de mestrado e doutorado orientados por estes docentes; e) por fim, as considerações finais.

\section{A Pós-Graduação em Ciências Sociais no Sul do Brasil e o tema do ensino}

Como é bem sabido, as Ciências Sociais passam a se institucionalizar primeiramente na Educação Básica e posteriormente no Ensino Superior, ainda que deva ter em mente que há diversas concepções de Ciências Sociais ao longo do tempo. Meucci (2015) destaca que no curso da Universidade do Distrito Federal (UDF), criado em $1935^{6}$, havia três "menções" possíveis para a graduação neste curso: Geografia, História e Sociologia, o que indica a existência de um arranjo curricular sensivelmente distinto daquele que há atualmente nos cursos que possuem esta mesma denominação.

Na Região Sul, o primeiro curso criado de Ciências Sociais foi na Universidade Federal do Paraná (UFPR), então Faculdade de Filosofia, Ciências e Letras do Paraná (FFCL) em 1938, e posteriormente, em 1940, é criado

6 Foram criados, em 1933, o curso de Ciências Sociais da Escola Livre de Sociologia e Política de São Paulo (ELSP), e, em 1934, o da Universidade de São Paulo (USP), sendo o da UDF, portanto, o terceiro criado no Brasil nesta área de conhecimento. 
o curso na Pontifícia Universidade Católica do Rio Grande do Sul (PUC RS). Em Santa Catarina, apenas na década de 1970 é que será criado um curso dessa natureza, não à toa Costa Pinto e Edison Carneiro não fazem referência a este Estado na publicação de 1955 intitulada "As Ciências Sociais no Brasil”.

Nesta primeira fase, encontramos um considerável contingente de professores "autodidatas" no campo das Ciências Sociais, o que se constituiu mais a regra do que a exceção nesse período Brasil afora ${ }^{7}$. Apenas nas décadas seguintes é que passamos a ter os primeiros egressos desses cursos, que passam a produzir pesquisas que possuem claros referenciais teóricos e metodológicos mais claramente delimitados a partir das Ciências Sociais.

Ainda que se possa reconhecer que as universidades brasileiras já vinham outorgando títulos de mestres e doutores ao menos desde a década de 1940 na área de Ciências Sociais, é com o cenário que se estabeleceu nacionalmente com a Reforma Universitária de 1968 que passaram a existir cursos de Mestrado e de Doutorado num modelo próximo ao que possuímos atualmente, de modo que é, sobretudo, a partir da década de 1970, que se desenvolve o sistema de pós-graduação que conhecemos hoje.

Na Região Sul, os primeiros Programas de Pós-Graduação em Ciências Sociais surgem ainda na década de 1970, havendo atualmente um programa de Sociologia Política, três programas de Ciência Política, três de Sociologia, quatro de Antropologia, e seis de Ciências Sociais, totalizando dezessete programas $^{8}$, como podemos observar na tabela abaixo:

7 Uma das poucas exceções deste período foi Gilberto Freyre (1900-1987), como indica o tralho de Meucci (2011), que, apesar de possuir título de graduação ou mestrado em Ciências Sociais, realizou, durante seus estudos de mestrado na Universidade de Colúmbia, cursos nos departamentos de Sociologia e de Antropologia desta instituição.

8 Considerando as áreas de avaliação da CAPES, haveria ainda outros programas, tais como: políticas públicas, integração contemporânea na América Latina etc., todavia, centramos nossa análise exclusivamente naqueles que oferecem formação disciplinar no campo das Ciências Sociais. Também deve-se considerar que estes dados se referem aos programas avaliados no último quadriênio (2013-2016). 
Quadro 1: Programas de Pós-Graduação em Ciências Sociais na Região Sul

\begin{tabular}{|l|l|c|c|c|c|}
\hline Instituição & Nome do Programa & UF & ME & ME/DO & Ano de Início \\
\hline UFRGS & Antropologia & RS & & $X$ & 1979 \\
UFRGS & Ciência Política & RS & & $X$ & 1973 \\
UFRGS & Sociologia & RS & & X & 1973 \\
UNISINOS & Ciências Sociais & RS & & $X$ & 1999 \\
PUC-RS & Ciências Sociais & RS & & $X$ & 2005 \\
UFSM & Ciências Sociais & RS & $X$ & & 2008 \\
UFPEL & Antropologia & RS & & $X$ & 2012 \\
UFPEL & Ciência Política & RS & $X$ & & 2011 \\
UFPEL & Sociologia & RS & $X$ & & 2012 \\
UFSC10 & SC & & $X$ & 1985 \\
UFSC & Antropologia & SC & & $X$ & 1985 \\
UFPR & Sociologia Política & PR & & $X$ & 1991 \\
UFPR & Antropologia & PR & & $X$ & 2009 \\
UFPR & Ciência Política & PR & & $X$ & 1997 \\
UEL & Sociologia & PR & $X$ & & 2000 \\
UEM & Ciências Sociais & PR & $X$ & & 2009 \\
UNIOESTE & Ciências Sociais & PR & $X$ & & 2010 \\
\hline
\end{tabular}

Fonte: Autores (2017)

Estes dados refletem um cenário mais amplo de consolidação dessa área de conhecimento no Brasil, ainda que não conste neste momento o ProfSocio, que será um mestrado profissional e que funcionará em rede, envolvendo na Região Sul inicialmente a UEL, a UEM e a UFPR.

Este quantitativo expressivo de programas vem acompanhado também de um número grande de linhas de pesquisa, que expressa a própria pluralidade temática que perpassa tais programas. Encontramos, segundo os dados da plataforma Sucupira, setenta e nove diferentes linhas de pesquisa, variando entre duas a doze o número de linhas nos programas analisados. Esta é uma tendência bastante geral encontrada nos Programas de Pós-Graduação de Ciências Sociais, como já indicara o estudo realizado por Lima e Cortes (2013), o que também representa a transversalidade existente nas linhas de pesquisa das Ciências Sociais, que:

9 No caso da UFPEL, havia um Programa de Pós-Graduação em Ciências Sociais, cujas atividades iniciaram em 2006, tendo se desdobrado nesses três diferentes programas.

10 Em 1978, foi criado o mestrado em Ciências Sociais, que posteriormente deu origem, em 1985, para os mestrados de Antropologia Social e de Sociologia Política. 
(...) reflete não apenas a amplitude dos temas abordados pela Sociologia e sua imbricação com as demais ciências sociais em termos teóricos e metodológicos, mas também a especificidade da análise sociológica. Essa especificidade, por sua vez, incorpora a contribuição das disciplinas próximas, sociologizando as contribuições de distintas tradições epistemológicas. De qualquer forma, essa transversalidade exige o permanente repensar da Sociologia enquanto disciplina e a formação de sociólogos assim como a formação em Ciências Sociais. (LIMA; CORTES, 2013, p. 431-432).

No caso aqui analisado, observa-se que, em meio às setenta e nove linhas de pesquisa indicadas, ao menos duas fazem referência explicitamente a questão educacional já em seus títulos: "Ciência, educação, técnica e ambiente” (PPGAS/UFSC) e "Identidades sociais, etnicidade e educação" (PPGCS/UFSM), além de outras três que em suas ementas fazem referências a pesquisas envolvendo o ensino superior, os sistemas de ensino e a educação de forma mais geral: "Sociedade e conhecimento" (PPGS/UFRGS), "Representações sociais e produções simbólicas” (PPGSP/UFSC) e "Cultura e sociabilidades” (PPGS/ UFPR), havendo uma única linha de pesquisa dedicada ao ensino de Sociologia junto ao PPGCS/UEL, como já havíamos indicado anteriormente.

Notadamente, a presença da palavra “educação” dispersa em meio a outras palavras-chave, seja no título, seja na ementa de uma linha de pesquisa, pode indicar amiúde a presença pontual de pesquisadores dedicados a esta temática, sem que isso implique a existência de um grupo de investigadores articulados a partir desta temática. Neste ponto, voltamos a dar relevo para a dispersão da agenda de pesquisa das Ciências Sociais brasileiras, marcada por uma crescente diversificação (MELO, 1999; LIEDKDE FILHO, 2005).

Considerando-se o cenário nacional, no qual há poucos Programas em Ciências Sociais que possuem linhas de pesquisa em diálogo com a pesquisa educacional (WEBER, 1992; LIMA; CORTES, 2013; OLIVEIRA; SILVA, 2016), pode-se inferir que temos aqui uma situação singular, na qual cerca de um terço dos programas possuem essa característica. Ainda que não se possa investigar a partir de nossas bases de dados os processos formativos destas linhas de pesquisa, pode-se inferir que elas emergem a partir da proximidade dos docentes que as compõem com os cursos de formação de professores, assim como com as próprias demandas locais e as políticas educacionais que fomentam pesquisas nesta área. 
Também chamam a atenção as indicações realizadas pelos programas no processo de avaliação CAPES, no qual um dos itens é o de inserção social, mais especificamente de interfaces com a educação básica. Em dois programas não conseguimos obter os dados referentes a este item de avaliação, e em três deles havia o indicativo de que o programa não realizava interface com a educação básica. Nos demais doze programas encontramos graus distintos de aproximação com a educação básica, que iam desde a atuação dos professores na licenciatura em Ciências Sociais, passando pela coordenação do Programa Institucional de Bolsas de Iniciação à Docência (PIBID), produção de material de apoio para professores da educação básica, realização de oficinas em escolas, isenção de taxas para professores da rede pública na participação de eventos, realização de cursos de especialização em ensino de Sociologia etc. Destaca-se que dois programas indicam que suas ações nesta seara se realizam por meio de Laboratórios de Ensino ${ }^{11}$, que coordenam as atividades e atuam principalmente através da extensão. Também é necessário pontuar que esta interface, ainda que seja dada prioritariamente através do ensino de Sociologia, não se limita a esta, envolvendo outras questões, tais como: o debate sobre gênero na escola, ensino religioso, ensino de história e cultura afro-brasileira, formação de professores indígenas.

Interessa-nos, portanto, saindo de uma dimensão mais descritiva, perceber que há institucionalmente nestes programas espaço para o desenvolvimento de pesquisas que dialogam com a educação, o que poderia abrir possibilidades para investigações ainda mais incisivas, que se situem mais especificamente no campo do ensino das Ciências Sociais. Todavia, como apontam os balanços recentes de Bodart e Cigales (2017) e de Handfas (2017), apesar de ainda haver mais trabalhos sobre ensino de Sociologia junto a programas de educação, esta temática vem ganhando espaço junto aos Programas de Ciências Sociais, sem que necessariamente isso ocorra apenas junto àqueles que possuem linhas de pesquisa na área de educação. Aparentemente, ainda que relevante, esta não é uma condição sine qua non para o desenvolvimento de pesquisas sobre ensino de Ciências Sociais em nível de mestrado e doutorado.

11 O Laboratório Interdisciplinar de Ensino de Filosofia e Sociologia (UFSC) e o Laboratório de Ensino, Pesquisa e Extensão de Sociologia (LENPES). 


\section{Os pesquisadores dedicados ao tema do ensino de Ciências Sociais}

Nos dezessete programas de pós-graduação aqui analisados, encontramos 342 docentes em atuação, seja categoria de permanente, colaborador ou visitante. Estes pesquisadores possuem diversos perfis formativos, alguns mais lineares no campo das Ciências Sociais ou áreas afins, outros mais híbridos. Nestes perfis, encontramos pesquisadores que possuíam ao menos um dos indicadores apontados acima, o que pode indicar que estas ações por vezes se dão de maneiras desarticuladas, sem que haja necessariamente um encadeamento entre ensino, pesquisa, produção acadêmica e orientação.

Dentro desta amostra inicial, selecionamos aqueles que possuíssem ao menos três dos quatro indicadores aqui mobilizados, de modo que chegamos a treze pesquisadores, o que representa apenas 3,8\% dos docentes que atuam nos Programas de Pós-Graduação em Ciências Sociais da Região Sul. Estes docentes encontram-se distribuídos da seguinte forma institucionalmente: dois no PPGS/UFPR, duas no PPGCS/UEL, dois no PPGCS/UEM, dois no PPGCS/UNIOESTE, um no PPGSP/UFSC, uma no PPGAS/UFSC, um no PPGS/UFPEL, um no PPGS/UFRGS, uma no PPGCS/UFSM.

O pequeno número de pesquisadores pode ser compreendido como um reflexo das próprias dinâmicas do campo acadêmico, uma vez que os esforços empreendidos na dinâmica universitária tendem a se voltar para objetos mais privilegiados e que garantem mais prestígio para os investigadores que se dedicam a eles (BOURDIEU, 2001). Ainda que percebamos um incremento das pesquisas envolvendo esta temática em nível de pós-graduação, isto não significa necessariamente um deslocamento do ensino para o centro de preocupações da agenda de pesquisa das Ciências Sociais. Neste ponto confluímos com Bodart e Cigales (2017, p. 277) ao indicarem que: "nossa hipótese é que a ampliação de dissertações seja mais um reflexo da necessidade de aperfeiçoar mão de obra docente para o Ensino Médio do que trazer definitivamente o tema para os centros das preocupações das pesquisas em Ciências Sociais/Sociologia ou Educação”.

Isso não significa dizer que os demais docentes destes programas não se dediquem à questão do ensino - há quarenta e dois professores que apresentam um dos indicadores aqui utilizados. Há casos nos quais eles lecionam 
disciplinas específicas da licenciatura em Ciências Sociais ${ }^{12}$, ou em que produzem na área, ou ainda em que orientam trabalhos sobre este tema, mas aparentemente desenvolvem estas atividades de modo mais pontual, focando suas atividades acadêmicas em outras áreas, recorrentemente naquelas às quais eles vêm se dedicando desde sua formação em nível de mestrado e/ou doutorado. A inserção na temática do ensino, neste caso, parece mais atender a demandas específicas, especialmente no campo da formação inicial docente, do que de fato constituir um eixo central nas investigações realizadas.

Chama a atenção a significativa concentração de pesquisadores deste grupo no estado do Paraná, o que se relaciona com uma série de fatores, como a atuação pioneira de algumas destas universidades - com destaque para a UEL - junto a escolas e secretarias de educação no processo de reimplantação da Sociologia no ensino médio ainda nos anos 1990 (SILVA, 2016).

Com relação à formação dos docentes que compõem este grupo, temos o seguinte quadro sintético:

Quadro 2: formação doutoral dos pesquisadores13

\begin{tabular}{|l|c|c|c|}
\hline Instituição vínculo & $\begin{array}{c}\text { Área do } \\
\text { Doutorado }\end{array}$ & $\begin{array}{c}\text { Ano de } \\
\text { Titulação }\end{array}$ & $\begin{array}{c}\text { Universidade na qual } \\
\text { obteve o título }\end{array}$ \\
\hline PPGS/UFRGS & Sociologia & 2011 & UFRGS \\
PPGS/UFPEL ${ }^{13}$ & Sociologia & 2011 & UFRGS \\
PPGCS/UFSM & Antropologia & 2005 & UFRGS \\
PPGAS/UFSC & Antropologia & 1998 & USP \\
PPGSP/UFSC & Sociologia & 2011 & UFPE \\
PPGCS/UEL & Sociologia & 2006 & USP \\
PPGCS/UEL & Ciências Sociais & 2009 & UNICAMP \\
PPGCS/UNIOESTE & Ciência Política & 2004 & USP \\
PPGCS/UNIOESTE & Ciência Política & 2004 & PUC-SP \\
PPGCS/UEM & Sociologia Política & 2013 & UFSC \\
PPGCS/UEM & Multimeios & 2005 & UNICAMP \\
PPGS/UFPR & Sociologia & 2006 & UNICAMP \\
PPGS/UFPR & Ciências Sociais & 2004 & UNICAMP \\
\hline
\end{tabular}

Fonte: Autores (2017)

12 São inúmeras as disciplinas que são lecionadas exclusivamente na licenciatura, que envolvem desde disciplinas com caráter mais teórico, como Sociologia da Educação, Antropologia da Educação, Sociologia no Ensino Médio, passando por aquelas que se relacionam mais diretamente à prática, tais como Metodologia de Ensino em Ciências Sociais, Estágio Supervisionado, Prática de Ensino etc.

13 O professor em questão é docente da UFRGS, na sua Faculdade de Educação, todavia é indicado como professor visitante no PPGS da UFPEL; todos os demais ocupam o lugar de professores permanentes em seus programas de pós-graduação. 
Este grupo é composto, portanto, por pesquisadores que possuem predominantemente a formação doutoral no campo da Sociologia, com uma participação mais tímida daqueles pertencentes à Antropologia e à Ciência Política. Possuem formação acadêmica obtida em importantes centros de pesquisa do país, com destaque para a UNICAMP, UFRGS e USP neste cenário. Quase todos fizeram seus estudos doutorais a partir dos anos 2000, de modo que é possível inferir que durante seu período formativo o debate sobre o ensino de Sociologia já estava posto em algum grau, e ao menos seis deles finalizaram sua graduação após a nova Lei de Diretrizes e Bases da Educação (Lei no 9.394/96), que em seu artigo $n^{\circ} 36$ indicava a necessidade do aluno egresso do ensino médio possuir conhecimentos de sociologia e filosofia, correspondendo assim a outra geração pedagógica de docentes (WEBER, 1996).

Ainda que em muitos casos a aproximação com a temática do ensino possa ter surgido a posteriori da formação acadêmica, é interessante notar que seis deles realizaram pesquisas relacionadas à educação no mestrado e/ou doutorado ${ }^{14}$, e, destes, duas professoras pesquisaram de forma mais direta o tema do ensino de Sociologia.

No que concerne às trajetórias acadêmicas de tais pesquisadores, seis deles atuaram na Educação Básica lecionando Sociologia antes de se tornarem professores universitários. Em suas instituições, doze deles lecionam com alguma regularidade disciplinas específicas da licenciatura, tanto aquelas envolvendo especificamente as metodologias de ensino e os estágios supervisionado, como também disciplinas com um caráter mais teórico, tais como "Antropologia da Educação”, "Sociologia da Educação”, "Educação e Sociedade” etc.

Estes dados referentes às trajetórias acadêmicas destes pesquisadores nos interessam na medida em que eles nos trazem elementos para compreendermos as tomadas de posição no campo, pois a escolha por transformar um tema pouco privilegiado nas Ciências Sociais brasileiras em objeto de pesquisa só pode ser compreendida de modo relacional, considerando a construção das disposições sociais (habitus) elaboradas ao longo de uma trajetória (BOURDIEU, 1996).

Sendo assim, as escolhas realizadas com relação à aproximação da temática do ensino não podem ser explicadas unicamente através dos ganhos simbólicos do campo acadêmico estritamente, uma vez que, partindo da pre-

14 Em dois casos, houve a realização de um mestrado em educação. 
missa que este é um tema de menor status nas Ciências Sociais brasileiras, agregaria mais capital simbólico a estes pesquisadores desenvolver atividades em outras temáticas. É através das trajetórias, dos deslocamentos nos campos (BOURDIEU, 1996), que encontramos a chave para compreender as escolhas realizadas. Mesmo entre aqueles que não pesquisaram temas relacionados à educação, nem atuaram na educação básica, encontramos entre suas atividades universitárias o desenvolvimento de funções que os aproximaram desta temática, seja através da docência de disciplinas relacionadas diretamente ao ensino, da coordenação de projetos institucionais ou de licenciaturas em Ciências Sociais.

Outro espaço de atuação institucional que se mostra relevante na definição dos perfis destes pesquisadores é o PIBID, no qual oito deles atuam ou atuaram como coordenadores ou colaboradores. Enquanto política pública, é válido pontuar que o PIBID constitui um elemento relevante, inclusive, para a própria delimitação e afirmação da identidade da licenciatura em Ciências Sociais enquanto curso de formação de professores. Como observa Santos (2017, p. 253):

(...) as mudanças nas condições institucionais no interior das universidades, como a implementação do PIBID, contribuíram para ancorar uma mudança nas condições epistemológicas sob as quais se desenvolvem a licenciatura. Houve uma transformação nas representações sobre a Sociologia e seu papel na escola e sobretudo na identidade do licenciando em Ciências Sociais - sujeito que passou a se reconhecer predominantemente como um professor de Sociologia em formação.

Destacamos assim que é, a partir das condições objetivas (políticas públicas, demandas institucionais da própria universidade etc.) e subjetivas (escolha por tema relacionado à educação durante a formação acadêmica, atuação na educação básica), que as disposições sociais destes pesquisadores vão se elaborando, uma vez que os habitus individuais são produto da interseção de séries causais parcialmente independentes, podendo ser considerados um traço individual de uma história coletiva (BOURDIEU, 2004), de tal modo que o interesse pelo tema "Ensino de Sociologia" deve ser entendido como uma construção. Ora, interesse, em termos sociológicos, é ao mesmo tempo uma condição para o funcionamento do campo e um produto deste. 
Isto significa também que estes agentes são ao mesmo tempo produto e produtores das disputas desenvolvidas no campo, inserindo-se na lógica mais ampla de produção e reprodução do campo científico, disputando o status de legitimidade do objeto de pesquisa ao qual se dedicam, ainda que em muitos casos haja também uma agenda mais ampla de pesquisa, que envolve outros objetos.

Neste processo, a própria presença de tais pesquisadores em seus respectivos Programas de Pós-Graduação constitui parte das estratégias no campo, já que estes são centrais na constituição da agenda de pesquisa das Ciências Sociais brasileiras. Da mesma forma, quatro deles já realizaram estudos pós-doutorais, sendo que três deles o fizeram no exterior (Portugal, Canadá e França foram os países escolhidos), o que também conflui com as estratégias disponíveis no campo. Dois deles são bolsistas de produtividade em pesquisa pelo CNPq, elemento considerado fundamental no campo científico brasileiro para a delimitação das hierarquias acadêmicas, e trata-se, portanto, de agentes que possuem uma posição privilegiada no campo.

O espaço institucional que estes pesquisadores ocupam engloba também as sociedades científicas, agentes importantes na delimitação das "regras do jogo”. Ganha destaque aqui a inserção junto a Sociedade Brasileira de Sociologia (SBS), Associação Brasileira de Antropologia (ABA) e Associação Brasileira de Ensino de Ciências Sociais (ABECS). Referimo-nos aqui não apenas à filiação institucional a tais associações, mas sim à presença de tais pesquisadores na diretoria destas instituições, bem como em comissões especiais, como a Comissão de Ensino da SBS e a Comissão de Educação, Ciência e Tecnologia da ABA.

Sendo assim, podemos vislumbrar que a atuação destes docentes nesta área de conhecimento reflete os múltiplos deslocamentos no campo, o que engloba a atuação profissional anterior à carreira de docente universitário, os temas de pesquisa desenvolvidos ao longo da formação acadêmica, o desenvolvimento de atividades na universidade, a inserção em associações científicas etc. Tais elementos se combinam no processo de constituição do habitus científico destes pesquisadores, na elaboração das disposições sociais que possibilitam que eles tenham interesse por esse objeto de pesquisa e, por consequência, acabem por inseri-lo num campo de disputas mais amplas do próprio campo científico. 


\section{Produção acadêmica na área de ensino}

Considerando a centralidade que a produção científica possui no processo de avaliação institucional da pós-graduação no Brasil junto à CAPES e, de modo mais geral, a centralidade que possui nas disputas em campo, é necessário dar visibilidade a esta questão, assim como ao processo de orientação de trabalhos de mestrado e doutorado nesta temática.

O habitus científico, ao menos dentro das regras do jogo atualmente postas no campo acadêmico brasileiro, pressupõe um interesse dos agentes no contínuo processo de divulgação de resultados das pesquisas por meio de publicações especializadas, não apenas através de eventos acadêmicos, como também de capítulos de livros, coletâneas, livros e, especialmente, artigos em periódicos especializados. Entretanto, as hierarquias acadêmicas são estabelecidas considerando também outras regras do jogo, que no caso brasileiro se vinculam ao sistema de avaliação de periódicos, o Qualis ${ }^{15}$, de modo que determinadas publicações trazem mais prestígio do que outras.

Neste tocante, é interessante retomar uma premissa assumida neste trabalho: o tema do ensino é um objeto pouco privilegiado nas Ciências Sociais brasileiras. Se a premissa aqui assumida é verdadeira, isso significa dizer que há maior dificuldade por parte destes pesquisadores em divulgar os resultados de suas investigações nos veículos de maior prestígio acadêmico, o que reforça a posição desta temática na hierarquia estabelecida entre os objetos de pesquisa neste campo.

Deve-se considerar, neste ponto, uma questão primordial: todo campo é marcado pela distribuição heterogênea de capitais, de modo que os diferentes agentes estão sempre em disputa, com a diferença que aqueles que possuem uma posição privilegiada no campo tendem a assumir posturas ortodoxas, diferentemente dos que estão em uma posição periférica, que tendencialmente apresentarão posturas heterodoxas, visando uma mudança de posição no campo (BOURDIEU, 2005).

15 Sistema de avaliação de periódicos mantido pela CAPES, no qual há oito níveis de classificação, havendo comitês organizados por áreas de conhecimento, que refletem a organização das próprias áreas dos programas de pós-graduação, de modo que o periódico pode ser avaliado por distintas áreas e receber notas diferentes a depender dos critérios adotados por cada um dos comitês. 
Uma das características que podemos observar nestes pesquisadores, a partir dos dados coletados, é que de fato eles estão engajados nas disputas científicas em curso, empenhados em diferentes graus na tarefa de legitimar o objeto de estudo de que se ocupam no campo das Ciências Sociais, assim como seu próprio lugar enquanto agentes deste campo. Neste contexto, as produções coletivas assumem um papel fundamental, tanto as coletâneas quanto os dossiês temáticos.

Dentre os treze pesquisadores aqui analisados, oito já foram organizadores de coletâneas ${ }^{16}$ e de obras coletivas que versaram sobre o ensino de Ciências Sociais, totalizando vinte livros publicados neste formato. Em contrapartida, poucos se dedicam à produção de obras individuais que versem sobre o assunto, neste caso, contabilizamos apenas duas produções, que são resultados de pesquisas realizadas em nível de pós-graduação.

Estes trabalhos coletivos parecem ser uma marca incisiva da produção nesta área, cuja confluência de esforços reflete esta tomada de posição no campo. Para sua elaboração, portanto, há uma demanda não apenas de capital científico, mas também social, já que há uma necessidade de envolver outros agentes que estão em campo. Com isso, marcam-se também as distinções que vão se colocando no processo de composição das regras do jogo, em meio à autonomização do ensino de Sociologia enquanto campo próprio. Sendo esta área tão dependente de produções coletivas, incluir ou excluir autores nestas coletâneas implica, a seu tempo, reforçar ou questionar as hierarquias acadêmicas.

Claro que as instâncias de legitimação acadêmica no campo do ensino de Sociologia passam também por outros espaços, ainda que estes não sejam necessariamente tão valorizados nas avaliações institucionais na pós-graduação. A coordenação de grupos de trabalhos - com destaque para o de Ensino de Sociologia junto ao Congresso Brasileiro de Sociologia -, a apresentação de papers em mesas redondas, fóruns e GTs que compõem a programação de eventos da área ${ }^{17}$, ou ainda a atuação junto ao Estado no âmbito das políticas educacionais ${ }^{18}$ também são instâncias importantes

16 Em alguns casos, dois ou mais pesquisadores são organizadores de tais coletâneas, incluindo aí pesquisadores que estão neste grupo analisado.

17 Destacam-se aqui o Congresso Brasileiro de Sociologia, a Reunião Brasileira de Antropologia, o Encontro da Associação Brasileira de Ciência Política e o Encontro da Associação Nacional de Pós-Graduação e Pesquisa em Ciências Sociais.

18 Vale a pena dar relevo neste caso à participação de acadêmicos no chamado Programa Nacional do Livro Didático (PNLD), que se caracteriza como uma política de Estado de avaliação, seleção e distribuição de livros didáticos em escolas públicas, na qual a Sociologia passou a atuar a partir de 2012. 
no reforçamento das distinções sociais existentes neste campo, ainda que sua importância seja relativa na avaliação institucional, como já indicado.

Enfatiza-se ainda que, em muitos casos, as coletâneas e dossiês surgem a partir de eventos (ERAS; OLIVEIRA, 2015), apresentando-se como sínteses das discussões realizadas. Sendo assim, a circulação por estes espaços representa uma possibilidade real de engajamento nas disputas acadêmicas.

Voltando novamente ao trabalho de Bodart e Cigales (2017), eles citam a existência de ao menos dezesseis dossiês organizados sobre o tema ensino de Sociologia/Ciências Sociais entre 2007 e 2017, e, ainda que este levantamento não abarque a totalidade dos dossiês organizados, ele pode nos dar uma pista sobre o lugar que esta temática ocupa na hierarquia acadêmica, já que nove destes 13 pesquisadores anteriormente referidos já publicaram em dossiês temáticos. Apenas dois destes números especiais foram publicados em revistas Qualis A na área de Sociologia ${ }^{19}$, sendo um deles em uma revista publicada por um programa de pós-graduação em educação e outro em uma revista de uma sociedade científica da área de Ciências Sociais.

Como bem nos esclarece Bourdieu (2011), o campo acadêmico não é gerido exclusivamente pela competência científica, a competência social também é um elemento fundamental para compreender sua dinâmica. Esta questão é relevante na medida em que o processo de organização e participação em um dossiê temático, assim como de uma coletânea, envolve também esta dimensão da competência social, e em grande medida estas publicações refletem também, ainda que não exclusivamente, a rede de relações de determinados agentes dispostos no campo. Reconhecendo-se assim a mutabilidade dos diversos tipos de capitais (BOURDIEU, 2009), passíveis de reconversão de um campo para outro, podemos inferir que os dossiês e coletâneas, em certo grau, também representam a conversão de capital social em capital acadêmico, ainda que essa conversão nunca seja precisa e total.

Se considerarmos o fato de que a produção em periódico deste grupo concentra-se em dossiês, isto pode significar que há uma dificuldade maior de publicação dos artigos que versam sobre essa temática na parte de "artigos livres" ou de "fluxo contínuo" dos periódicos especializados. Neste caso, a

19 Tratam-se dos dossiês publicados na revista Educação e Realidade (v. 39, n. 1, 2014), e na Revista Brasileira de Sociologia (v. 2, n. 3, 2014). Apesar de não ter sido citado pelos autores, também a revista Ciências Sociais (UNISINOS) organizou um dossiê sobre o tema. Estas três revistas são Qualis A2 na área de Sociologia. 
organização de dossiês pode ser compreendida como uma estratégia que visa a legitimação desse objeto de pesquisa no campo das Ciências Sociais brasileiras, uma estratégia de disputa. Reconhece-se assim que estas produções coletivas, os dossiês e as coletâneas, são as principais estratégias utilizadas na disputa em que estes agentes estão engajados no campo acadêmico.

\section{Orientações na Pós-Graduação}

Um dos pontos fulcrais da dinâmica acadêmica é o processo de reprodução do corpus que compõe a universidade, o que se dá essencialmente através da formação de quadros em nível de pós-graduação. Desse modo, é esperado que uma das principais finalidades dos programas de pós-graduação seja a formação de especialistas dentro de determinada área do conhecimento, inserindo-os ainda dentro de determinados temas de pesquisa, o que possibilita a constituição e ampliação de uma comunidade de pares.

Considerando tais questões, observamos aqui o processo de orientação em nível de pós-graduação de trabalhos vinculados à temática do ensino de Ciências Sociais, tendo em vista tanto os trabalhos já defendidos quanto aqueles que ainda estão em curso. Talvez este seja o item distribuído de forma mais heterogênea entre os pesquisadores analisados, uma vez que depende mais de fatores contingenciais, principalmente do interesse e capacidade de aprovação em processo seletivo dos alunos que almejam ingressar nos programas de pós-graduação em que atuam.

Dos treze docentes aqui analisados, apenas um deles não havia orientado nenhum trabalho de mestrado e/ou doutorado; todos os demais contavam com orientações concluídas e em curso. Entretanto, apenas sete deles possuíam orientações vinculadas ao tema do ensino de Ciências Sociais, majoritariamente vinculando-se à questão do ensino de Sociologia no ensino médio. Contabilizam-se quatorze trabalhos concluídos em nível de mestrado e uma tese de doutorado, esta versando sobre o ensino de Antropologia no ensino superior.

Encontram-se ainda em desenvolvimento mais cinco dissertações de mestrado e três teses de doutorado, sendo uma delas sobre ensino de Antropologia no ensino superior. Isto significa que, apesar dos influxos recentes nas políticas educacionais, que afetaram diretamente o ensino de Sociologia, este tema continua a ser pesquisado nos programas de pós-graduação. 
Chama a atenção que, no caso das três teses de doutorado distribuídas entre três diferentes docentes que pertencem a programas distintos ${ }^{20}$, trata-se da orientação de alunos que realizaram sua formação anterior, em nível de graduação ou de mestrado, em outras instituições, o que pode significar que a busca pela realização de seus estudos doutorais nestes programas também se deveu ao fato de haver pesquisadores considerados referências no campo do ensino das Ciências Sociais, motivando a vinda de estudantes de outras universidades para estes programas de pós-graduação. Ademais, destes três doutorandos, dois deles já haviam pesquisado o ensino de Ciências Sociais no mestrado, e o terceiro havia pesquisado questões relacionadas à educação.

Observando os Lattes também daqueles que foram ou são orientandos destes pesquisadores, uma questão interessante emerge: em alguns casos, os mestrandos e doutorandos foram também bolsistas durante a graduação de projetos ligados ao ensino de Ciências Sociais, especialmente do PIBID. Isso significa que está em curso o processo de elaboração de um habitus científico que reconhece o ensino de Ciências Sociais como um objeto relevante, que merece ser pesquisado.

Para compreender esse processo, é necessário levar em consideração determinadas características presentes nestes programas desenvolvidos na graduação, tais como:

(...) o longo período que se passa no interior da universidade, o contato próximo e regular com os membros do grupo (professores e pós-graduandos), e a internalização de certas posturas e competências, muitas vezes transmitidas de modo implícito ou sutil - formam um ambiente propício ao desenvolvimento de um habitus acadêmico-científico. E é justamente esse habitus que orienta os estudantes em direção à pós-graduação, ao mesmo tempo em que funciona como um "senso de jogo" que permite ao indivíduo agir de maneira a obter o êxito. (NOGUEIRA; CANAAN, 2009, p. 67)

Apesar do trabalho de Nogueira e Canaan se referir ao Programa Institucional de Bolsas de Iniciação Científica (PIBIC), em algum grau ele pode também ser aplicado à realidade de estudantes que participam de outros programas, tais como o PIBID. Há de se considerar, portanto, que, para este

20 PPGS/UFPR, PPGSP/UFSC, PPGAS/UFSC. 
habitus acadêmico-científico, a existência de docentes em pós-graduação desenvolvendo pesquisas, publicando e orientando em determinada área de conhecimento é fundamental para a construção de disposições sociais que percebem o ensino como um objeto de pesquisa relevante no campo das Ciências Sociais.

Sendo assim, ao mesmo tempo em que o processo de ensino, pesquisa, produção e orientação destes docentes é condicionado pela estrutura do campo acadêmico, e pelas hierarquias nele existentes, ele também é estruturante e condiciona as práticas de outros agentes, como no caso daqueles que buscam desenvolver seus estudos de pós-graduação explorando o tema do ensino.

\section{Considerações Finais}

O trabalho aqui presente lança luz sobre alguns aspectos ainda pouco explorados no campo do Ensino das Ciências Sociais, pois, ainda que os balanços realizados tenham possibilitado que vislumbremos a dimensão quantitativa da produção acumulada, pouco tem sido problematizado em torno da real capacidade desta produção alterar o status do ensino no campo das Ciências Sociais brasileiras.

Ainda que não estejamos aqui analisando o cenário nacional como um todo, pensar o ensino de Ciências Sociais a partir dos programas e dos pesquisadores do Sul do Brasil mostra-se como um locus privilegiado para a realização desta análise, considerando a proeminência que estes agentes alcançaram em termos nacionais.

Observou-se que a ausência de linhas de pesquisa específicas no campo da educação na maior parte dos programas não inviabilizou o desenvolvimento de investigações em nível de mestrado e de doutorado envolvendo este tema, o que fora garantido pelos pesquisadores inseridos nestes programas.

O interesse dos docentes pelo tema do ensino pode ser explicado pelo processo de construção de determinadas disposições sociais (habitus), que incluem para alguns o desenvolvimento de pesquisas relacionadas à educação durante a formação acadêmica e/ou a atuação anterior na educação básica, ou ainda a inserção em determinadas atividades universitárias, como coordenação de projeto PIBID e/ou de curso licenciatura, ou ainda a atuação junto a disciplinas específicas dos cursos de formação de professores. Isto 
tem se desdobrado na inserção destes agentes em outros espaços, como sociedades científicas e fóruns acadêmicos específicos.

Destaca-se ainda que, no terreno das disputas em campo, as produções coletivas ganham visibilidade, tanto através das coletâneas quanto dos dossiês temáticos, demandando destes agentes não apenas competência científica como também social, para construir redes de pesquisadores que colaborem entre si nestas produções. Por outro lado, o mesmo processo revela a dificuldade encontrada de inserção da produção relativa ao ensino nos periódicos da área na modalidade "demanda contínua”, o que pode indicar a perduração do status do ensino no campo das Ciências Sociais.

Também foi verificada a existência de um número significativo de trabalhos orientados em nível de pós-graduação envolvendo o ensino, de tal modo que podemos supor que a atratividade de alunos para a realização de estudos em nível de pós-graduação reflete, em algum grau, o êxito nas estratégias acadêmicas adotadas por estes agentes, o que inclui o desenvolvimento de pesquisas na área do ensino de Ciências Sociais, participação em fóruns, congressos e atividades diversas de sociedades científicas, publicação de trabalhos, especialmente aqueles de natureza coletiva etc.

As disputas estão postas no campo e, evidentemente, os agentes encontram-se engajados nelas. A temática do ensino segue-se periférica na agenda de pesquisa das Ciências Sociais brasileiras, entretanto, este é um cenário dinâmico e que tem se alterado sensivelmente nos últimos anos; assim, tendo em vista a próxima geração de pesquisadores que vêm sendo formados inseridos nesta discussão, é possível supor que nos próximos anos a comunidade de pares nesta área será ampliada e possivelmente passará a ocupar novas posições no campo.

\section{Referências bibliográficas}

AZEVEDO, Gustavo Cravo. (2015), A trajetória do PL 3.178/1997 no Congresso Nacional: o discurso dos parlamentares, dos não especialistas, na defesa da presença da sociologia no ensino médio. In: OLIVEIRA, Evelina; OLIVEIRA, Amurabi. Ciências sociais e Educação: um reencontro marcado. 1 ed. Maceió: EDUFAL. pp. 61-79.

BODART, Cristiano; CIGALES, Marcelo. (2017), Ensino de Sociologia no Brasil (1993-2015): um estado da arte na pós-graduação. Revista de Ciências Sociais, v. 48, n. 2, pp. 256-281. 
BOURDIEU, Pierre. (2004), Coisas ditas. 1 ed. São Paulo: Editora brasiliense. BOURDIEU, Pierre. (2011), Homo academicus. 1 ed. Florianópolis: EDUFSC. BOURDIEU, Pierre. (2005), O poder simbólico. 8 ed. Rio de Janeiro: Bertrand Brasil.

BOURDIEU, Pierre. (2009), O senso prático. 1 ed. Petrópolis: Vozes.

BOURDIEU, Pierre. (2001), Para uma sociologia da ciência. 1 ed. Lisboa: Edições 70.

BOURDIEU, Pierre. (1996), Razões práticas. 7 ed. Campinas: Papirus.

CAREGNATO, Célia Elizabete; CORDEIRO, Victoria Carvalho. (2014), Campo científico-acadêmico e a disciplina sociologia na escola. Educação \& realidade, v. 39, n. 1, pp. 39-57.

ERAS, Ligia; OLIVEIRA, Ricardo Costa. (2015), Uma sociologia dos livros coletâneas sobre o ensino de sociologia na educação básica (2008-2013). In: OLIVEIRA, Evelina; OLIVEIRA, Amurabi. Ciências sociais e educação: um reencontro marcado. Maceió: EDUFAL. pp. 81-101.

HANDFAS, Anita. (2017), As pesquisas sobre o ensino de sociologia na educação básica. In: SILVA, Ileizi; GONÇALVES, Danyelle Nilin. Sociologia na educação básica. São Paulo: Annablume. pp. 367-385.

LIEDKE FILHO, Enno. (2005), A sociologia no Brasil: história, teorias e desafios. Sociologias, v. 7, n. 14, pp. 376-436.

LIMA, Jacob Carlos; CORTES, Soraya Maria Vargas. (2013), A sociologia no Brasil e a interdisciplinaridade nas ciências sociais. Civitas, v. 13, n. 3, pp. 416-435.

MELO, Manuel Palácios da Cunha. (1999), Quem explica o Brasil?. 1 ed. Juiz de Fora: EDUFJF.

MEUCCI, Simone. (2015), Artesania da sociologia no Brasil: contribuições e interpretações de Gilberto Freyre. 1 ed. Curitiba: Appris.

MEUCCI, Simone. (2011), Institucionalização da sociologia no Brasil: primeiros manuais e cursos. 1 ed. São Paulo: Hucietec; Fapesc.

NOGUEIRA, Maria Alice; CANAAN, Mariana Gadoni. (2009), Os “iniciados”: os bolsistas de iniciação científica e suas trajetórias acadêmicas. Tomo, s/v, n. 15, pp. 41-70.

PINTO, Costa; CARNEIRO, Edison. (1955), As ciências sociais no Brasil. 1 ed. Rio de Janeiro: CAPES (Série Estudos e Ensaios, $\mathrm{n}^{\circ}$ 6).

OLIVEIRA, Amurabi. (2016), A expansão dos cursos de formação de professores de ciências sociais na região Sul do Brasil. Revista Brasileira de Sociologia, v. 4, n. 7, pp. 241-264. 
OLIVEIRA, Amurabi; SILVA, Camila. (2016), A sociologia, os sociólogos e a educação no Brasil. Revista Brasileira de Ciências Sociais, v. 31, n. 9, pp. $1-15$.

SANTOS, Mario Bispo. (2017), O PIBID na área de ciências sociais: da formação do sociólogo à formação do professor de sociologia. Tese de Doutorado em Sociologia - Programa de Pós-Graduação em Sociologia. Brasília: Universidade de Brasília.

SILVA, Ileizi F. (2016), Das fronteiras entre ciência e educação escolar: as configurações do ensino das Ciências Sociais/Sociologia no Estado do Paraná (1970-2002). 1 ed. Porto Alegre: CirKula.

WEBER, Silke. (1992), A produção recente na área de educação. Cadernos de Pesquisa, s/v, n. 81, pp. 22-32.

WEBER, Silke. (1996), O professorado e o papel da educação na sociedade. 1 ed. Campinas: Papirus. 


\title{
Modernización Productiva y Gestión del Riesgo en la Actividad Industrial Uruguaya
}

\author{
Francisco Pucci*
}

\section{RESUMEN}

En este trabajo, nos planteamos analizar la articulación entre modelos de seguridad, organización y gestión de recursos humanos en tres ramas de producción del Uruguay: la construcción, la rama forestal y la rama papelera. La elección de estas ramas permite comparar esta articulación en contextos productivos disímiles en términos de trayectoria y desarrollo. La industria de la construcción ha sido el paradigma sobre el cual se construyó la normativa vigente en materia de seguridad; la rama forestal es un sector de actividad nuevo en Uruguay, desarrollado a través de empresas multinacionales que reprodujeron en el nuevo contexto productivo las políticas de sus casas matrices. De la industria papelera tomaremos como ejemplo una de las empresas más tradicionales del país, que mantiene muchos de los rasgos matriciales del período de sustitución de importaciones en el cual fue creada.

Palabras clave: Gestión. Riesgo. Industria

* Doctor en Sociología. Profesor Titular del Departamento de Sociología. Facultad de Ciencias Sociales, Montevideo, Uruguay. 


\begin{abstract}
PRODUCTIVE MODERNIZATION AND RISK MANAGEMENT IN THE URUGUAYAN INDUSTRIAL ACTIVITY
\end{abstract}

In this paper, we set out to analyze the articulation between models of security, organization and management of human resources in three branches of production in Uruguay: construction, the forestry branch and the paper branch. The choice of these branches makes it possible to compare this articulation in dissimilar productive contexts in terms of trajectory and development. The construction industry has been the paradigm on which the current regulations on safety were built; the forestry branch is a new activity sector in Uruguay, developed through multinational companies that reproduced the policies of their parent companies in the new productive context. From the paper industry we will take as an example one of the most traditional companies in the country, which maintains many of the matrix features of the period of import substitution in which it was created.

Keywords: Industry. Risk. Management

\title{
Introducción
}

Este trabajo se propone analizar la gestión del riesgo en diferentes ramas industriales del Uruguay, a partir de la idea de que la implementación de las políticas de seguridad no se constituye en un campo autónomo de acción, sino que se articula con las formas de organización que se dan las empresas y con las políticas de gestión de recursos humanos que se desarrollan en las mismas. Si las políticas de gestión de recursos humanos tuvieron un retraso relativo en relación a los cambios tecnológicos, las políticas de seguridad y de gestión del riesgo lo tuvieron aún más. Esta problemática comienza a incorporarse fuertemente a la discusión pública a partir del 2009, con la aprobación de diferentes decretos que impusieron a las empresas la constitución de comisiones de seguridad y la contratación de técnicos especializados en la gestión del riesgo. De todas maneras, pese a estos impulsos, cuyos orígenes los podemos encontrar en los acuerdos bilaterales de la rama de la construcción, la articulación entre gestión de recursos humanos y gestión del riesgo sigue siendo un espacio de asincronías y contradicciones.

Este trabajo de nutre de investigaciones realizadas en diferentes momentos históricos, que permiten mostrar los niveles de desarrollo de la gestión del riesgo en Uruguay a lo largo de los últimos años. En este trabajo, nos 
planteamos analizar la articulación entre modelos de seguridad y gestión de los recursos humanos en tres ramas de producción del Uruguay: la construcción, la rama forestal y la rama papelera. La elección de estas ramas permite comparar esta articulación en contextos productivos disímiles en términos de trayectoria y desarrollo.La industria de la construcción ha sido el paradigma sobre el cual se construyó la normativa vigente en materia de seguridad; la rama forestal es un sector de actividad nuevo en Uruguay, desarrollado a través de empresas multinacionales que reprodujeron en el nuevo contexto productivo las políticas de sus casas matrices. De la industria papelera tomaremos como ejemplo una de las empresas más tradicionales del país, que mantiene muchos de los rasgos matriciales del período de sustitución de importaciones en el cual fue creada.

El análisis se basará en la contrastación y discusión, a partir de tipos ideales conocidos en la literatura académica, de la evidencia empírica proveniente de las investigaciones realizadas. Esta evidencia fue recogida básicamente a través de entrevistas a diferentes segmentos laborales de las empresas más representantivas del sector. Se trata, por lo tanto, de un muestreo teórico, que nos permite construir tipologías de para dar cuenta de los elementos en común de los diferentes casos, pero no nos permite establecer generalizaciones a todo el universo ni conclusiones generales para todas las empresas de las ramas analizadas.

\section{Organización y modelos de seguridad}

Como planteamos en trabajos anteriores (Pucci, Nión, Mannise, 2014), en la discusión sobre los modelos de seguridad, Amalberti (2013) propone una síntesis definiendo la seguridad de los sistemas complejos como el resultado de la suma de dos entidades: el de la seguridad derivada de las normas y procedimientos (seguridad regulada), y el de la inteligencia adaptativa de los operadores y los profesionales del sistema (seguridad gestionada).

De la combinación de estas dos entidades se deducen tres modelos de seguridad:

- El modelo resiliente: la búsqueda de la exposición al riesgo constituye la esencia misma del modelo. La seguridad está asociada a ganar, sobrevivir; sólo los ganadores trasmiten sus conocimientos sobre seguridad a través de sus relatos. 
- El modelo de la H.R.O (High Reliability Organizations): hay que gestionar los riesgos diariamente, aunque el objetivo principal sea controlarlos y no exponerse a ellos. La seguridad depende del grupo, de la organización, de los roles y las competencias de cada uno. El modelo analiza sus fracasos e intenta comprender sus causas.

- El modelo de los sistemas ultraseguros: requiere operadores equivalentes, intercambiables. Apuesta a las cualidades de supervisión que son las que van a evitar que estos operadores se expongan a los riesgos más fortuitos, limitando dicha exposición a una lista finita de fallos y dificultades.

Estos tres modelos de seguridad son radicalmente diferentes, responden a condiciones económicas distintas, tienen su propia lógica de optimización, su propio sistema de formación, sus ventajas y sus límites. Esto implica que estos modelos no son miscibles, por lo que las empresas u organizaciones deben necesariamente optar por alguno de ellos. Tampoco es sencillo el pasaje de un modelo a otro en la misma organización: las intervenciones que se realizan pueden mejorar o modificar aspectos del modelo pero no su lógica básica. Para pasar de un modelo a otro se precisa de un elemento de fractura que abarque toda la profesión y su economía.

La construcción de estos modelos se basa en los diferentes mecanismos de regulación que cada uno de ellos conlleva y el papel que juegan los actores en el mismo. Estos modelos, a su vez, presuponen diferentes formas de comunicación interna y de relacionamiento entre las partes del sistema. En este sentido, la aplicación y desarrollo de los modelos de seguridad no se pueden comprender fuera del marco de las diferentes configuraciones organizacionales en las que se despliegan y de las políticas de reclutamiento del personal, formación y capacitación, carreras laborales y los demás componentes de la gestión de recursos humanos. La hipótesis que orienta este trabajo es que los modelos de seguridad dependen básicamente de las formas de organización de la producción, pero esta dependencia no es directa ni mecánica. La articulación se produce a través de las políticas de gestión de los recursos humanos. El punto de encuentro entre ambas lógicas se sitúa en los mecanismos de coordinación de la actividad productiva, como los define Mintzberg (1989) Estos mecanismos de coordinación son también mecanismos de regulación que impregnan la gestión de los recursos humanos y las culturas de la organización 
El primer tipo de configuración organizacional que tomaremos en cuenta en este trabajo es, siguiendo a Mintzberg, la burocrática maquinal. La misma se caracteriza por llevar adelante una fuerte estandarización de los procedimientos, mediante herramientas de análisis de las operaciones de los trabajadores, descripción de puestos de trabajo y desarrollo de normas de comportamiento ligadas a estos puestos. En esta configuración, típica de las grandes organizaciones burocráticas, la tecnoestructura tiene un rol preponderante en el proceso de normalización de las actividades. Estas configuraciones son estables y tienden a desarrollarse en entornos que no les generan fuertes incertidumbres. Las relaciones de poder, a su vez, pasan por los mecanismos de control jerárquico sobre la base del respeto a las normas de procedimiento y a la planificación previa de la actividad. Este tipo de configuración tiene fuertes resistencia al cambio y dificultades para adaptarse a demandas variadas y complejas.

Un segundo tipo de configuración organizacional lo constituye la innovadora. La misma se caracteriza por una estructura fluida, descentralizada, en la cual equipos de expertos y técnicos trabajan en proyectos puntuales y específicos que la organización debe llevar adelante. Estas organizaciones son aptas para dar cuenta de entornos complejos y dinámicos, que generan demandas diversificadas y de alta complejidad técnica. En general se trata de organizaciones jóvenes, en proceso de expansión, con importantes dosis de democracia interna, regulados por procesos de adaptación mutua poco formalizados. Las complejas actividades que deben llevar adelante los equipos técnicos requieren capacidades de inventiva y de resolución de problemas, lo que vuelve contraproducente el desarrollo de procesos de normalización de actividades. Este tipo de configuración, si bien es eficaz para dar cuenta de las demandas del entorno, lo hace muchas veces en desmedro de la eficiencia.

El tercer tipo de configuración que tomaremos es la empresarial. En esta, el mecanismo de coordinación predominante es la adaptación mutua y la supervisión directa de las tareas, en un contexto de escasa división técnica del trabajo. La figura central la constituye el empresario que da impulso y continuidad al proyecto productivo: las relaciones sociales están marcadas por un alto grado de informalidad. No existen carreras laborales y las relaciones de autoridad son de tipo personal.. Este configuración se corresponde a las empresas jóvenes que aún no han aumentado la cantidad de personal ni han 
diversificado fuertemente las tareas a realizarse. Pichault y Nizet (2000), en una tentativa de sistematización de diferentes dimensiones de la gestión de recursos humanos, asocian el modelo "arbitrario”, a la configuración empresarial. Este tipo de gestión está centrada en las decisiones de la dirección, fundadas en criterios personales, intuitivos y discrecionales y sostenidas por la autoridad directa del empresario o grupo de dirección.

Los mecanismos básicos de coordinación de estas configuraciones son diferentes. La configuración maquinal coordina sus actividades a través de la estandarización de procesos en tanto la configuración innovadora lo hace a través de la adaptación mutua, lo que implica que las estructuras de poder al interior de estas dos configuraciones responden a lógicas distintas. Pichault y Nizet (2000) asocian el modelo “objetivante” a la configuración maquinal. En este modelo, las relaciones sociales son reguladas de acuerdo a criterios impersonales, aplicados de manera universal a todos los integrantes de la organización. La cultura asociada al modelo “objetivante” valoriza el respeto de la autoridad jerárquica y la aplicación de la regla, a cambio de la protección que les brindan a los integrantes. Las normas tienen un componente de protección dado que preservan a los trabajadores de las arbitrariedades y favoritismos de los jefes. Las carreras profesionales se construyen en torno a reglas impersonales respetadas por todos: antigüedad, concursos o credenciales educativas. En este modelo, el tiempo de trabajo está claramente establecido y diferenciado del tiempo de placer, y cualquier esfuerzo extra debe ser recompensado.

Este modelo de gestión de recursos humanos se acopla más fácilmente a los modelos de seguridad altamente regulados, en los cuales la seguridad depende del acatamiento de las reglas y de los procedimientos diseñados e implementados por los expertos. Las dificultades más importantes de este modelo se refieren a la normalización del desvío como tensión inherente a la aplicación de las normas. Como lo indica Bourrier, (2001) la normalización del desvío se presenta cuando la transgresión de reglas importantes de seguridad no sólo es ampliamente conocida sino además tolerada y aceptada por los pares y la jerarquía. La fuerte tensión entre las presiones económicas y las exigencias de seguridad favorece este proceso, debido a que los actores administran esta tensión desviándose habitualmente de ciertas normas de seguridad porque estiman que su aplicación rigurosa es negativa para el desempeño económico de la empresa. 
En la perspectiva de la H.R.O., en cambio, las estrategias y las lógicas de estructuración de los actores pasan a un segundo plano, así como los conflictos de poder y las luchas internas. Tampoco son tomados en cuenta las condiciones efectivas, en el terreno, que permiten que los actores acepten las exigencias. La existencia de las H.R.O. presupone, según sus teóricos, que estos conflictos fueron reglados de alguna manera. Estas organizaciones actúan sobre la base de la construcción de relaciones de confianza con el público y entre los grupos e individuos que participan de la misma. El eje de estas organizaciones de alta fiabilidad es lograr la confianza institucional tanto a nivel interno de la organización como en relación a otros organismos públicos y privados y al público en general. Junto a la noción de confianza institucional, La Porte (2001) enfatiza las condiciones que garantizan la constancia de esta confianza a lo largo del tiempo. En este sentido, debe existir la voluntad política e institucional de la organización y su determinación de conservar esta confianza y la capacidad de la organización de mantener intactos sus compromisos a lo largo del tiempo.

La alta fiabilidad se logra a través de un exitoso acoplamiento entre la organización, sus miembros y el medio ambiente (Bourrier, M. 2001). La seguridad y la fiabilidad se construyen en el marco de una negociación cotidiana entre las exigencias reglamentarias, las obligaciones laborales y las oportunidades estratégicas de los actores. Estos arbitrajes están enmarcados por representaciones sociales, visiones del mundo, relaciones simbólicas y rituales de socialización que contribuyen a estabilizar el sistema a través de equilibrios más o menos perjudiciales para la seguridad (Bourrier, M. 2001).

Este modelo de seguridad se asocia al desarrollo de una configuración organizacional de tipo innovador y a un modelo de gestión de recursos humanos de tipo "individualizante" centrado en el concepto de competencia; las capacidades y saberes de los trabajadores son las que estructuran las relaciones de trabajo en la organización. La cultura organizacional se construye en torno al logro y buena ejecución de proyectos diversos y complejos, fundadas en las competencias de grupos de trabajadores con niveles relativos de autonomía, sustentadas con políticas de formación y de aprendizaje permanentes. Estas tendencias obligan a la organización a generar mecanismos de integración del personal para mantener los niveles de cooperación imprescindibles para el funcionamiento de la misma. Las tensiones más importantes de este modelo derivan del traslado de las responsabilidades de 
la organización al individuo, que asume la carga de alcanzar las metas y los objetivos. La ambivalencia central que caracteriza este modelo radica en la tensión permanente entre dos polos: por un lado, el individuo tiene un margen de autonomía en sus opciones, pero, al mismo tiempo, esta autonomía está controlada en la medida en que las decisiones se deben corresponder a los objetivos y metas planteados por la organización.

Por último, los modelos artesanales tienen puntos de contacto con la configuración empresarial. En este tipo de organización, el peso de las normas y procedimientos es menor, las relaciones sociales están teñidas de personalismo y discrecionalidad, en tanto la autoridad pasa por las decisiones subjetivas de la jerarquías. Estas organizaciones escasamente reguladas, cuya lógica de funcionamiento descansa en la adaptación de los miembros a los cambios de contexto, son un espacio proclive para el desarrollo de modelos en los cualesl a seguridad descansa en la capacidad de los operadores directos para exponerse y adaptarse continuamente a las situaciones de riesgo inherentes al proceso de trabajo, en la cual ponen en juego su experiencia práctica y el conocimiento de oficio adquirido a través del aprendizaje práctico.

En estos modelos, la gestión del riesgo se construye a través de procesos de regulación autónoma. En este plano, Reynaud (1988) plantea que en una organización siempre existen dos fuentes de regulación: la regulación de control y la regulación autónoma. La regulación de control es formal y explícita, orientada por criterios técnicos y racionales. La regulación autónoma, por su parte, si bien es informal, no es espontánea ni caprichosa. Es una regulación muy elaborada, compartida por los trabajadores, que se enseña a los nuevos miembros y que se impone a aquellos que no la aceptan. En este plano, las regulaciones reales son compromisos inestables entre control y autonomía. La variedad de compromisos en muy grande, tanto como los procesos necesarios para alcanzarlos. Estos modelos se sustentan en la cultura de oficio como mecanismo de regulación de la conducta de los trabajadores en relación a la seguridad. Sin embargo, esta cultura de oficio puede estar fragmentada por la presencia de "chacras" sectoriales, barreras generacionales y distancias jerárquicas; las reglas que conforman la regulación autónoma surgen de una negociación compleja e implícita atravesada por diferentes oposiciones. Esto implica que las regulaciones de una empresa no forman un conjunto coherente: son más bien el resultado acumulado, el apilamiento o las combinaciones poco articuladas de prácticas y reglas que son 
de naturaleza, origen, época e inspiración muy diferentes y hasta opuestas En la medida en que son multidimensionales, las regulaciones constitutivas de los diferentes grupos están cargadas de valores, tradiciones y obligaciones, que van más allá de las necesidades inmediatas de producción.

\section{El riesgo en la industria de la construcción}

La industria de la construcción es uno de los sectores productivos claves para entender la gestión del riesgo en la realidad productiva del Uruguay. La actividad de la construcción, a diferencia de otros procesos productivos, tiene componentes de riesgo permanentes, que no están asociados al desarrollo tecnológico moderno ni al aumento de la complejidad de los sistemas productivos. En este sentido, el análisis de la gestión del riesgo en la construcción asume connotaciones especiales, en la medida en que existe un conjunto establecido de prácticas, normas de comportamiento, hábitos laborales, así como una profusa reglamentación jurídica en torno al tema. El análisis de la gestión del riesgo en la actividad de la construcción nos coloca frente a un sector paradigmático para comprender a fondo los procesos de regulación social que se establecen en torno al riesgo, en la medida en que los desarrollos que se produzcan en este sector han sido utilizadas de ejemplo práctico para ramas industriales o procesos productivos en los cuales los factores de riesgo sean relativamente novedosos.

A partir de 1996, la negociación colectiva a nivel de rama estableció una nueva normativa orientada a reducir la accidentalidad en el sector. Dentro de esta regulación, se destaca dos normas: i) la obligación impuesta a las empresas de contratar a un técnico prevencionista para orientar y promover políticas de seguridad en cada empresa; ii) la creación de la figura del delegado obrero de seguridad, elegido por los trabajadores para representar a los mismos en las discusiones y negociacionen en torno a la seguridad. La normativa aplicada tiene sus bases en estos acuerdos centrales a nivel de rama que se aplican en las empresas que implementan medidas de seguridad. Sin embargo, existe una fuerte asincronía entre la normativa de seguridad y las características de los procesos de trabajo que se implementan en la industria de la construcción, que sufren, en numerosas ocasiones, el impacto de la introducción tecnológica y de los procesos de descentralización productiva. 
A su vez, las figuras del delegado obrero de seguridad y del técnico prevencionista tuvieron dificultades en la implementación efectiva de sus respectivos roles. En el caso del técnico prevencionista, las dificultades parecen estar centradas en que, más allá de sus cometidos formales definidos por la ley, la función más importante que cumplen es la de deslindar las responsabilidades de la empresa en caso de accidente, estableciendo procesos de inculpación y exculpación, más que la promoción de la prevención y la capacitación. En el caso del delegado obrero de seguridad, las dificultades parecen estar centradas en los problemas de reclutamiento y las debilidades de su formación y capacitación. En este marco, su rol aparece asociado, según las circunstancias específicas, sea a la actividad sindical, sea a las políticas de la empresa, sea a la actividad de control del Ministerio de Trabajo y Seguridad Social (MTSS). Esta confusión con respecto a los ejes centrales que debe tener el rol de delegado obrero de seguridad dificulta la construcción de fuentes de legitimidad específicas para el desempeño del mismo. Estas nuevas figuras se agregan a las funciones de control y asesoramiento que históricamente estuvieron y están bajo la responsabilidad del MTSS. En este plano, se producen innumerables formas de superposición o de confusión de funciones entre los diferentes roles, que a su vez corresponden a adscripciones institucionales, profesionales y gremiales diferentes, que no logran establecer espacios de comunicación y traducción para construir un lenguaje común que permita ordenar y complementar las funciones de los diferentes roles.

La configuración organizacional predominante en la industria es un híbrido entre la maquinal basada en la estandarización de procesos, y la empresarial, centrada en las decisiones unilaterales del gestor o empresario. Sin embargo, los procesos de trabajo están débilmente estandarizados y las relaciones sociales están teñidas de particularismos y de lealtades personales. Su estilo de gestión de recursos humanos combina elementos del modelo "objetivante” reseñado más arriba, con elementos del modelo "arbitrario”, que Pichault y Nizet asocian a la configuración empresarial, con formas la autoridad más personalizada. Esta combinación genera tensiones que se expresan en las dificultades para aplicar normas generales y abstractas en un sistema de relaciones jerárquicas teñidos de componentes arbitrarios y particularistas.

Las políticas de seguridad que se implementan en la industria de la construcción, si bien implican un importante esfuerzo en términos de inversión 
y energía, reflejan una matriz mecánica de gestión de los riesgos (Dourlens et al, 1991) apoyada fundamentalmente en la jerarquía vertical y en el cumplimiento de requisitos y normas externas. El enfoque de estas políticas se inspira en el modelo ultraseguro definido por Amalberti, en el cual la seguridad descansa en el cumplimiento de normas y protocolos. Esta perspectiva de gestión del riesgo la encontramos tanto en empresas multinacionales que han implementado herramientas de gestión que mejoran la calidad y la seguridad, como en empresas ligadas al mercado interno, que desarrollan estrategias de reducción de costos tercerizando y descentralizando el proceso productivo.

También encontramos una "cultura de riesgo" (Douglas, 1985) implícita compartida por los actores involucrados en las relaciones laborales de la industria de la construcción. La percepción y valoración del riesgo que tienen el Estado, los empresarios y los trabajadores, tienen numerosos puntos en común. Esta "cultura de riesgo” también se asocia a un modelo mecánico de evaluación de los riesgos, donde se considera que la reducción de los accidentes pasa principalmente por el cumplimiento de la normativa y la inversión económica, sin tomar en cuenta la complejidad de los procesos sociales asociados al riesgo y la irreductibilidad de los mismos. Estas culturas de riesgo se asocian fuertemente al modelo de seguridad implementado, por lo que su génesis tiene un fuerte componente organizacional.

Para el caso de los trabajadores de la construcción, estas "culturas de riesgo" son elaboraciones contingentes y puntuales, que no se deducen de sus procesos de socialización primaria, sino que son el producto de un aprendizaje organizacional que se desarrolla en el marco de los procesos de trabajo, rutinas laborales y reglas de comportamiento conformados en cada empresa o lugar de trabajo. Estas características obligan a centrar el análisis en los componentes específicos de cada organización concreta más que en las actitudes o idiosincracia de los “trabajadores de la construcción” como categoría homogénea, dotada de valores y normas de comportamiento independientes del contexto productivo en el cual desarrollan la actividad.

Esta discusión es importante en términos de definición de responsabilidades. Los empresarios tienden a atribuir el accidente a conductas que se asocian a características intrínsecas de la "cultura de trabajo" de los obreros de la construcción, sin considerar que la misma se conforma en la propia estructura de la organización. Otro aspecto a destacar es que las responsabili- 
dades con relación al riesgo no están claramente definidas, lo que impide el desarrollo de una actividad de regulación autónoma que colme las lagunas que deja la reglamentación formal y jurídica. Los procesos de tercerización y de descentralización del proceso productivo dificultan el establecimiento de responsabilidades jurídicas en el caso de que ocurra un accidente. Como señala Douglas (1985), la definición de responsabilidades permite que los diferentes actores impongan sus normas la evolución de las normas formales e informales, jurídicas y autónomas, escritas e implícitas, requieren la definición de un gestor al cual remitir las responsabilidades emergentes. En la medida en que esta figura no se visualiza, la actividad de regulación se ve también debilitada.

\section{La modernización de la industria forestal}

El sector forestal uruguayo ha experimentando en los últimos años un proceso de modernización de su actividad productiva, a través de la implantación, en diferentes regiones del país, de empresas nacionales o extranjeras, que realizaron importantes inversiones en infraestructura y tecnología. (Pucci, Nión, Ciapessoni, 2014) Esta modernización tuvo como consecuencia un creciente proceso de formalización de la mano de obra contratada para trabajar en el sector, mejorando notoriamente las condiciones de empleo de los trabajadores de las regiones en las cuales las empresas se instalaron, los cuales se desempeñaban en actividades rurales de baja calificación y en condiciones precarias desde todo punto de vista. Esta modernización tecnológica introducida por la actividad forestal al mundo rural, no tuvo su correlato en el desarrollo de formas de gestión de la mano de obra más adecuadas a los cambios productivos realizados. Las relaciones jerárquicas y las relaciones de cooperación mantienen rasgos típicamente tradicionales, en los cuales el particularismo y el paternalismo propios de las relaciones en el mundo rural se insertan en estructuras productivas modernizadas. La tercerización del proceso de trabajo y la formación de cuadrillas de pequeñas cantidades de trabajadores, en las que los criterios de reclutamiento son particularistas y teñidos por relaciones familiares o de vecindad, conforman un espacio de relaciones sociales especifico, que lo diferencia de otras actividades productivas. Si bien en la producción industrial tradicional uruguaya, la presencia de lazos familiares o de vecindad constituye un criterio de reclutamiento 
de mano de obra, la lógica productiva tiende a conformar relaciones más abstractas y universales en el mundo del trabajo. En la actividad forestal, las relaciones familiares y de vecindad se instalan en un proceso de trabajo altamente fragmentado, que refuerza este tipo de vínculo particularista.

Las principales empresas de producción forestal se conforman como un hìbrido entre la configuración individualizante, basada en la competencia y en la individualizaciòn organizativa, con componentes del modelo empresarial centrado en relaciones informales y personales. En relación a las políticas de seguridad, coexisten lineamientos modernos inspirados en la perspectiva de las H.R.O., con dispositivos de autoridad de tipo particularista, en particular en las relaciones de los trabajadores de las cuadrillas con sus contratistas. La pervivencia de relaciones sociales tradicionales choca, por un lado, con las posibilidades de implementación de políticas de seguridad en el sentido de las H.R.O., en la medida en que no generan las condiciones propicias para el desarrollo de espacios de confianza entre los trabajadores ni de formas de confianza institucional. El modelo se acerca a las típicas formas de "toyotismo precario" que De la Garza Toledo (2010) ha analizado en las formas de producción de diversos países de América Latina.

Los espacios de confianza que generan las condiciones para una gestión del riesgo eficiente, se construyen a través de largos procesos de intercambio en los cuales las conductas de los actores se vuelven predecibles unas con respecto a las otras. Presuponen, a su vez, espacios de comunicación más horizontales, sustentados en el reconocimiento y el respeto mutuo. En estos casos, los mecanismos de control son más internos y se construyen sobre la base del respeto de un conjunto de reglas de juego compartidas. Las formas de gestión tradicionales, en cambio, reproducen relaciones de bajo niveles de confianza, que requieren de mecanismos de control externos y que generan permanentes discusiones sobre la legitimidad de las decisiones.

Estas relaciones se inscriben, a su vez, en un proceso de trabajo altamente fragmentado por la fuerte tercerización del proceso productivo, lo que refuerza la construcción de realidades sociales en las cuales se intensifican las relaciones internas de cada grupo o cuadrilla pero se construyen espacios heterogéneos de vínculos personales en el marco del proceso de trabajo. Esta fuerte heterogeneidad del proceso de trabajo en términos de relaciones sociales, constituye una dificultad importante en la construcción de relaciones de comunicación más fluidas entre los que implementan las políticas 
de seguridad y aquellos que las ejecutan. También constituye una dificultad para el desarrollo de políticas generales basadas en criterios generales y universales, que se deben implementar en espacios fuertemente marcados por vínculos personales y particulares.

Los modelos de gestión con componentes tradicionales coexisten con el desarrollo de políticas integradoras en materia de seguridad en el trabajo, a través de dispositivos de autoridad cuya legitimidad se construye en el marco de las relaciones cara a cara entre el jerarca y sus subordinados. Esta coexistencia de procesos de vocación universal con relaciones particularistas hace recaer en la relación que los contratistas tienen con sus trabajadores, las mayores o menores posibilidades de éxito de los procesos de gestión del riesgo en estas empresas. La atribución de las responsabilidades en caso de accidentes, también tiende a descentralizarse, aunque la gestión global del proceso de trabajo se realiza a nivel central. Las tensiones entre la fijación de criterios centrales en las políticas de seguridad y la descentralización de las responsabilidades constituye otro desafío importante en materia de gestión del riesgo del mundo forestal.

\section{La industria papelera tradicional}

En la industria papelera, hemos analizado un caso que se corresponde al modelo clásico de desarrollo industrial nacional de larga data en el país. La empresa papelera que analizaremos fue fundada en 1898. Se constituyó originalmente con capitales uruguayos, pero desde el año 2007 pertenece a un grupo foresto-industrial con operaciones en Argentina y Uruguay. A diferencia de lo que sucede con otras competidoras de la rama, esta empresa es la única que integra en su proceso de trabajo desde la forestación de los eucaliptos, la cosecha y trozado de la madera y la producción de celulosa, hasta el procesamiento para su transformación en papel y su posterior comercialización. (Pucci; Nión; Mannise; 2014)

El diseño organizacional de la empresa papelera se asocia fuertemente a la configuración maquinal, aunque su conformación muestra rasgos más atenuados que los señalados por Mintzberg. La estandarización de procesos es relativa, debido a que mantiene fuertes componentes artesanales; las normas son muy laxas y las relaciones personales mantienen un peso considerable en el funcionamiento cotidiano de la organización. En ese senti- 
do, si bien la forma burocrática maquinal es la predominante, la empresa combina también rasgos de la configuración empresarial, caracterizada por una mayor informalidad en las relaciones y un estilo de conducción más personalizado. La empresa, si bien se configura como una organización burocrática maquinal, en su estilo de gestión de recursos humanos combina, como en el caso de la industria de la construcción, elementos del modelo “objetivante” reseñado más arriba, con elementos del modelo "arbitrario", con formas del autoridad más personalizadas y mecanismos de gestión más informales.

La gestión del riesgo en la empresa analizada se implementa en un proceso productivo con una matriz taylorista débil, que se articula con relaciones de tipo tradicional y donde existen espacios para el desarrollo de lógicas artesanales sustentadas en el conocimiento técnico. Si bien el formato organizacional originario se estructura a partir de normas objetivas impersonales y universales, las políticas de gestión de los recursos humanos se sustentan en una lógica de tipo arbitrario, marcadas por la discrecionalidad, la desconfianza y la presencia de fuertes tensiones en las relaciones jerárquicas. Este estilo de gestión impide la construcción de confianza y de espacios de integración entre mandos y trabajadores, lo que aleja este caso del modelo de H.R.O. expuesto más arriba.

La empresa cuenta con un conjunto de normas y de protocolos de seguridad que se implementan desde la dirección para mejorar la prevención de accidentes. Estas normas, en la práctica, son violadas de manera cotidiana por los trabajadores y por los encargados de producción. En la medida en que la normalización del desvío se convierte en una práctica permanente, la seguridad se logra a través de la adaptación de los trabajadores a las situaciones de riesgo y a la construcción autónoma de los colectivos de trabajo. La debilidad de los mecanismos de regulación técnica y las dificultades para lograr una regulación conjunta entre gerencia y sindicato ponen de relieve la importancia de la regulación autónoma del riesgo en este contexto laboral. La regulación del riesgo descansa en los saberes prácticos de los trabajadores, conformados a través de su experiencia de trabajo y su formación técnica.

La formación en seguridad, a su vez, sigue los mismos recorridos que la formación técnica: el aprendizaje de las situaciones de riesgo se realiza a través de la experiencia directa en estrecho contacto con los trabajadores de mayor antigüedad. Un ejemplo de este tipo de aprendizaje son las paradas 
de emergencia, que se realizan en caso de que surja algún riesgo en el proceso de trabajo. Las tensiones surgen debido a que estos procesos de formación en la temática de seguridad, por estar ligados a un vínculo directo con un trabajador más experiente y de mayor jerarquía, están marcados por estas relaciones personales, que atraviesan el peso de las normas organizacionales y son fuente de conflicto en términos jerárquicos y generacionales.

En este contexto productivo, la gestión de la seguridad se caracteriza por la presencia predominante de una cultura de oficio como mecanismo de regulación de la conducta de los trabajadores, como prolongación de las normas informales que regulan la producción. Empero, dicha cultura de oficio está fragmentada por la presencia de "chacras" sectoriales, barreras generacionales y distancias jerárquicas. En este sentido, las reglas que conforman la regulación autónoma surgen de una negociación compleja e implícita atravesada por clivajes sectoriales, generacionales y jerárquicos. Por otro lado, desde la gerencia existe una tendencia al desconocimiento de las culturas de oficio existentes, que se expresa en políticas de gestión de personal que desvalorizan el acervo de conocimiento construido y acumulado en la experiencia de trabajo. Estas políticas se implementan en un contexto de constante superposición de herramientas de gestión de recursos humanos, que marcan un entorno de incertidumbre laboral poco propicio para el desarrollo de formas de confianza entre trabajadores y gerencia, entre jerarquías y nivel operativo, entre sectores y equipos de trabajo, y entre generaciones de trabajadores. Asimismo, existe una escasa reflexividad por parte de los trabajadores en relación a los componentes de su cultura de oficio. Si bien esta opera de hecho, no es explicitada por el colectivo, y menos aún es reconocida como tal en el marco de tensiones y competencias entre sectores y equipos de trabajo.

\section{Discusión de los casos estudiados}

Los tres casos analizados nos permiten señalar las grandes tendencias de la industria uruguaya en materia de seguridad. Podemos distinguir dos tipos ideales. El primer tipo se corresponde con las industrias nacidas en la etapa de industrialización de importaciones de los años 30 y 40 en Uruguay. Estas industrias, de capitales originalmente uruguayos, tuvieron una fuerte protección estatal para su desarrollo, orientaron su producción al 
mercado interno, y fueron intensivas en mano de obra, con escasa inversión en tecnología. A partir de los años 80, la industria uruguaya comienza a implementar procesos de reestructuración productiva y de transformación tecnológica para acompasarse a las exigencias de los mercados internacionales. En este marco, se crearon condiciones favorables para la incorporación de equipos y tecnología, especialmente en las industrias de exportación. Los incentivos económicos a estas actividades, la caída de los aranceles, la sobrevaluación de la moneda y la afluencia de préstamos internacionales favorecieron el reequipamiento industrial del período.

En el caso uruguayo, la incorporación y adaptación de nuevas herramientas de gestión se realiza en un contexto industrial de tipo patrimonial, donde predominan vínculos de tipo paternalista y particularista que permean todas las relaciones sociales de tipo fabril. Lejos de sustentarse en criterios abstractos e impersonales de logro, eficiencia y competitividad al estilo de las grandes empresas del mundo desarrollado, las relaciones sociales en las empresas capitalistas uruguayas están teñidas de "familismo" y lealtades personales. Estos particularismos atraviesan la organización productiva, de la cual no se puede decir que siga estrictamente los criterios de tipo taylorista fordista típicos de otros contextos productivos. En ese sentido, la organización del trabajo tradicional en la industria uruguaya, si bien se inspira en los métodos y las concepciones tayloristas-fordistas, lo hace de manera más atenuada en cuanto a sus efectos que lo que ha sido en otros contextos.

Esta realidad productiva se traduce en dificultades para lograr la legitimidad de las normas de seguridad, en un contexto marcado por una lógica de lealtades personales y de particularismos. En estas empresas, el modelo de seguridad más generalizado es el ultraseguro, asociado a la persistencia de la matriz taylorista de las primeras etapas de la industrialización sustitutiva de importaciones. A su vez, esta matriz taylorista tuvo una implantación débil, por lo que los procesos productivos mantienen sectores de trabajo con fuertes componentes artesanales. La falta de legitimidad de estos modelos lleva al desarrollo de fuertes espacios de regulación autónoma para compensar la debilidad del modelo original, sustentados en el conocimiento de oficio de los trabajadores.

El segundo tipo ideal lo constituyen las ramas industriales más modernas de la realidad productiva uruguaya, como la forestal. Este sector ha experimentando en los últimos años un proceso de modernización de su 
actividad productiva, a través de la implantación, en diferentes regiones del país, de empresas extranjeras que realizaron importantes inversiones en infraestructura y tecnología. Esta modernización tuvo como consecuencia un creciente proceso de formalización de la mano de obra contratada para trabajar en el sector, mejorando notoriamente las condiciones de empleo de los trabajadores de las regiones en las cuales las empresas se instalaron. Estos se desempeñaban en actividades rurales de baja calificación y en condiciones precarias desde todo punto de vista. . El perfil de los trabajadores que se incorporan a la actividad forestal se diferencia del clásico trabajador de las estancias ganaderas del Uruguay. La mayoría procede de zonas urbanas y tiene una fuerte presencia de jóvenes con bajos niveles de educación formal. Una novedad de este tipo de actividad es la incorporación de la mujer al trabajo forestal, en particular en los procesos de trabajo de plantación de los viveros, en los cuales su manualidad más fina la hace más preferible que el hombre. La modernización del sector en términos tecnológicos y de organización del trabajo cambian las características típicas del trabajo rural, sustentado en la fuerza física y en la resistencia corporal, para aproximarlo a las modalidades del trabajo industrial. Este cambio tiene como consecuencia el aumento de las exigencias de capacitación y formación de la mano de obra, que debe desarrollar capacidades y habilidades para manejar tecnologías y procesos de trabajo más calificados.

Sin embargo, pese a estos importantes cambios que acompañaron la modernización del sector, la actividad forestal mantiene dos características históricas: la estacionalidad y la tercerización del proceso de trabajo. La estacionalidad de la producción forestal es una condición inherente a un tipo de actividad en la cual la dinámica y evolución de los factores naturales juegan un rol importante, a lo cual se le puede agregar como factor complementario las oscilaciones de la demanda de productos forestales. Esta característica de la producción forestal tiene impactos en las modalidades de contratación de la mano de obra. Si bien la actividad forestal implicó un fuerte proceso de formalización de las condiciones de empleo, la figura predominante sigue siendo la del trabajador jornalero, que cobra su salario de acuerdo a la cantidad de días que trabaja, y que está sujeto a los vaivenes de la demanda de trabajo inherente a la estacionalidad de la producción. Junto a este trabajador jornalero, que ha constituido la modalidad histórica de contratación de la actividad forestal, se conforma un grupo de trabajadores estables, que 
cobran mes a mes con independencia de los ritmos de producción, y que desarrolla actividades de mayor nivel de responsabilidad para la empresa.

Estas empresas desarrollan políticas de seguridad inspirados en el modelo H.R.O., lo que mejoró notablemente las condiciones de trabajo y de seguridad. Sin embargo, estas políticas encuentran sus límites en las contradicciones inherentes a esta configuración productiva, que implementa un conjunto de dispositivos y normativas según las concepciones más modernas sobre seguridad, en un contexto marcado por la precarización de las relaciones laborales y por formas de gestión de la mano de obra con fuertes improntas tradicionales. La zafralidad del trabajo y la presencia de la modalidad de contratación por jornal, conspiran con procesos de formación de la fuerza de trabajo en el largo plazo, que requieren condiciones de estabilidad que no están presentes en el trabajo forestal.Estas relaciones se inscriben, a su vez, en un proceso de trabajo altamente fragmentado por la fuerte tercerización del proceso productivo, donde la empresa contratante es la que fija las condiciones de trabajo y establece las normativas generales de las políticas de seguridad, pero su traducción efectiva se hace a través de los múltiples contratistas de los cuales dependen las diferentes cuadrillas de trabajadores que componen el proceso de trabajo.

\section{Conclusiones}

Los casos analizados permiten discutir y profundizar las relaciones entre las configuraciones organizacionales y los modelos de seguridad que se conforman en las mismas. Los modelos de seguridad ultra seguros parecen articularse con mayor facilidad con las configuraciones burocráticas, en las cuales las normas son relativamente homogéneas, unívocas, impuestas desde la macroestructura y compartida por los miembros de la organización. Estas normas se corresponden con estructuras que poseen un carácter relativamente fijo, estable, que ordena, configura y permite prever la acción de los individuos. Esto nos habla de un mayor nivel de determinismo estructural, en el cual el pasado posee una fuerte preeminencia sobre los cursos de acción y los desempeños presentes de los actores. En términos de Giddens, (1995) nos encontramos ante agentes que poseen baja reflexividad, es decir, escasa capacidad de absorber información y conocimiento (incluido el experto) de manera tal de lograr reapropiarse del tiempo y las circunstancias 
en las que se encuentran. Consecuentemente, tiende a predominar como criterio de regulación, una racionalidad técnica/experta, axiológicamente neutra y el saber profano se encuentra generalmente excluido y poco activo.

Los modelos de seguridad inspirados en el modelo H.R.O., en cambio, se articulan mejor en configuraciones organizacionales de tipo innovador, centradas en la competencia y en la habilidad de los operadores directos. En estos contextos, las normas pierden sus características de homogeneidad, formalidad y univocidad, lo que influye también en los tipos de control social y en la distribución de responsabilidades. La jerarquía y la centralización de las decisiones son sustituidos por formatos institucionales más descentralizados y horizontales, en los cuales el control social aparece más difuminado en la estructura institucional. Se replantean también las relaciones entre actores técnicos y actores profanos, desplazando al conocimiento técnico como actor absoluto en la esfera de la decisión política e instaurando un juego complejo entre expertos y operadores directos.

Por último, las reglas presentes en los modelos artesanales se diferencian de las normas formales de los modelos anteriores. En primer lugar, son reglas implícitas, producidas en el marco de la racionalidad práctica de los actores. Esto hace que su análisis deba dejar de lado la consideración de las normas formales y explícitas para centrarse en el análisis de los códigos de conducta subyacentes al comportamiento de los actores. En segundo lugar, son reglas producidas en contextos de incertidumbre, por lo que no constituyen una construcción estable y coherente; su duración y alcance es limitado y provisorio. La inestabilidad endógena, la complejidad y las contradicciones entre reglas opuestas constituyen sus rasgos más salientes. Dadas estas características, estos sistemas de reglas pueden tener, a su vez, efectos perversos, en la medida en que se constituyen en respuestas adecuadas en determinados registros de comportamiento pero se transforman en fuentes de riesgo en otros registros. Esto implica también que las fuentes de legitimidad de las normas también están ligadas al grupo que las impone.

Estas conclusiones permiten avanzar en la discusión sobre culturas de riesgo y calidad del empleo en la realidad productiva uruguaya. Los estudios realizados muestran que, en Uruguay, el aprendizaje de la gestión del riesgo nos enfrenta a un conjunto de instituciones, organizaciones y comunidades técnicas que se encuentran en el primer peldaño de este proceso de aprendizaje. Las “culturas de riesgo” institucionales también tienen un 
carácter limitado y específico. Incorporar la gestión del riesgo en las conductas cotidianas de usuarios, técnicos e instituciones implica un largo proceso de acumulación y aprendizaje, que se encuentra, en los casos analizados, en sus primeras etapas. La profundización de este proceso de aprendizaje dependerá del alcance y magnitud de las situaciones de riesgo, aunque nada indica, a priori, que estas situaciones sean aprovechadas y capitalizadas para mejorar su gestión.

A su vez, las políticas de seguridad se asocian a un modelo mecánico de evaluación de los riesgos, donde se considera que la reducción de los accidentes pasa principalmente por el cumplimiento de la normativa y la inversión económica, sin tomar en cuenta la complejidad de los procesos sociales asociados al riesgo y la irreductibilidad de los mismos. Los procedimientos también reflejan una perspectiva mecánica de la gestión del riesgo, que se apoya fundamentalmente en la jerarquía vertical y en el cumplimiento de requisitos sometidos a controles externos, dejando de lado formatos más horizontales que den cuenta y se reapropien del saber y del "saber hacer" de los operarios.

En los casos estudiados, la gestión del riesgo no parece articularse con procesos globales de aprendizaje organizacional, que impliquen modificaciones en las rutinas de trabajo y en los comportamientos cotidianos de los actores laborales, procesos que se deben construir tomando en cuenta las diferentes perspectivas y orientaciones en juego en cado espacio concreto. Este proceso de aprendizaje organizacional requiere, como condición necesaria, una fluida relación de intercambio entre agentes técnicos y agentes profanos, que genere condiciones de confianza. La jerarquía y la centralización de las decisiones no son sustituidas por formatos institucionales más descentralizados y horizontales, en los cuales el conocimiento técnico deje de ser el referente único y absoluto, generando espacios de intercambios y negociaciones permanentes entre expertos, decisores y trabajadores. Esta dimensión no parece presente en la mayoría de las empresas analizadas.

La gestión del riesgo está orientada, en el mejor de los casos, a lograr una exitosa internalización de normas de conducta o de valores asociados a la seguridad. Si bien este aspecto parece una condición necesaria, la manera de resolver las incertidumbres que se presentan requiere de un proceso de construcción de reglas con componentes más horizontales e implícitos, que se traduzcan en rutinas de trabajo más eficientes. Las opciones y elecciones son por lo tanto mucho menos estructuradas, más coyunturales y situacio- 
nales, sustentadas fundamentalmente sobre el conocimiento práctico de los trabajadores. Esta alternativa se apoya en modalidades de regulación más descentralizadas y autorreguladas, donde las unidades pasan a tener una gran dosis de autonomía. La recuperación y comunicación del saber práctico de los trabajadores y de su capacidad de generar, de manera colectiva, reglas de conducta adecuadas a los contextos de incertidumbre, es una condición central en los procesos de gestión del riesgo. Esto implica pensar los mismos desde modelos más complejos que aseguren el aprendizaje permanente y la construcción cotidiana de comportamientos y reglas que articulen el saber técnico y el saber profano.

\section{Bibliografía}

Amalberti, René. (2013) Construir la seguridad. Compromisos individuales y colectivos para afrontar los grandes riesgos. Editorial Monduslaborandi. Madrid.

Bourrier, Mathilde (2001) La fiabilité est une question d'organisation. En:Organiser la fiabilité. Sous la direction de Mathilde Bourrier. L'Harmattan, París.

De la Garza Toledo, Enrique. (2010)Hacia un concepto ampliado de trabajo. Del concepto clásico al no clásico. Editorial Anthropos, UNAM, México.

Dourlens, Christine.;Galland, Jean Pierre.; Vidal-Naquet, Pierre (1991) Introduction. En:Dourlens C., Galland J.P., Theys J.; Vidal-Naquet P.A., Conquête de la sécurité, gestion des risques,L'Harmattan, Paris.

Douglas, Mary (1985) Risk acceptability according to the social sciences.In: Russel Sage Foundation, New-York.

Giddens, Anthony (1995):La Constitución de la sociedad. Ed. Amorrortu, Buenos Aires.

La Porte (2001) Fiabilité et légitimité soutenable.En:Organiser la fiabilité. Sous la direction de.Bourrier, M. L'Harmattan.

Mintzberg, Henry (1989) El poder en la organización.Ariel, Barcelona.

Pichault, Francois.;Nizet, Jean. (2000) Les pratiques de gestion des ressources humaines. Collection Points Essais, Paris.

Pucci, Francisco.;Nión, Soledad.; Mannise, Sofía. (2014) La regulación autónoma del riesgo: el caso de una empresa papelera En: El Uruguay desde la Sociología 12. Departamento de Sociología, F.C.S. Universidad de la República. Montevideo, 2014. ISBN 978-9974-0-1141-0 
Pucci, Francisco.; Nión, Soledad.; Ciapessoni, Fiorella. (2014) Condiciones de trabajo y gestión del riesgo en las empresas forestales uruguayas. Biblioteca plural, CSIC, Universidad de la República. ISBN 978-9974-0-1060-4, Montevideo.

Pucci, Francisco; Levin,Rodolfo; Trajtenberg, Nicolás; Bianchi, Carlos. (2006) La negociación de los umbrales aceptables de riesgo en la industria de la construcción uruguaya. Departamento de Sociología, Facultad de Ciencias Sociales, Universidad de la República. Imprenta La Canasta, San José, Uruguay,. 2006. 260 pgs.

Reynaud, Jean Daniel. (1988) Les règles du jeu. L'action collective et la régulation sociale. París. A. Colin. 


\title{
A Indústria 4.0 e o Futuro do Trabalho: Tensões e Perspectivas
}

\author{
Marcelo Augusto Vieira Graglia * \\ Noêmia Lazzareschi* *
}

\section{RESUMO}

Este artigo tem como objetivo apresentar e analisar os dados fornecidos pelas recentes pesquisas sobre a utilização das tecnologias de informação, de comunicação e de inteligência e o seu impacto sobre os mundos do trabalho nos países mais desenvolvidos do mundo. Concentra-se não apenas na automatização e robotização do processo de produção, mas nas novas formas de execução do trabalho em todos os setores da vida econômica que se transformam graças à utilização da inteligência artificial, blockchain, big data e profusão de aplicativos para a satisfação de um sem número de necessidades sociais. Procura demonstrar as tensões sociais que resultam das profundas mudanças dos mercados de trabalho a partir da reestruturação produtiva provocada pela introdução das novas tecnologias e novas técnicas de gerenciamento do processo de trabalho, ressaltando não só um de seus efeitos negativos mais temidos pelos trabalhadores - o aumento do desemprego -, mas também e sobretudo as possibilidades de um futuro brilhante para toda a humanidade, definitivamente liberada das tarefas repetitivas, simplificadas, insignificantes que impedem a realização das potencialidades humanas de inteligência, criatividade, espírito crítico e iniciativa. Palavras-chave: Indústria 4.0. Inteligência artificial. Desemprego estrutural.

* Doutor em Tecnologias da Inteligência e Design Digital pela Pontifícia Universidade Católica de São Paulo. Mestre em Engenharia Mecânica pela Universidade Estadual Paulista Júlio de Mesquita Filho - UNESP. Graduado em Engenharia Mecânica pela Universidade de Taubaté. Pesquisa inteligência artificial, indústria 4.0, cidades inteligentes, internet das coisas, trabalho, emprego e reestruturação produtiva. Professor da Faculdade de Economia e Administração da Pontifícia Universidade Católica de São Paulo.

* * Possui mestrado em Sciences Sociales Du Travail - Université Catholique de Louvain (1971) e doutorado em Ciências Sociais pela Universidade Estadual de Campinas (1995). Atualmente é assistente doutor da Pontifícia Universidade Católica de São Paulo. Tem experiência na área de Sociologia, com ênfase em Sociologia do Trabalho, atuando principalmente nos seguintes temas: trabalho, turismo, reestruturação produtiva, emprego e tempo livre. 


\section{ABSTRACT \\ INDUSTRY 4.0 AND THE FUTURE OF WORK: TENSIONS AND PERSPECTIVES}

This article aims to present and analyze the data provided by the recent research on the use of information technology and your impact on the world of work in the most developed countries in the world. Focuses not only on automation and robotization of the production process, but in new ways of performing the work in all sectors of economic life that if transformed thanks to the use of artificial intelligence, blockchain, big data and profusion of applications for the satisfaction of a number of social needs. Seeks to demonstrate the social tensions resulting from changes in labor markets from the productive restructuring brought about by the introduction of new technologies and new techniques of process management work, emphasizing not only one of his most feared negative effects by employees - rising unemployment - but also and above all the possibilities of a bright future for all humanity, definitely released of repetitive tasks, simplified, insignificant that prevent the realization of the human potential of intelligence, creativity, critical spirit and initiative. Keywords: Industry 4.0. Artificial intelligence. Structural unemployment.

\section{Introdução}

O desenvolvimento da tecnologia ao longo da história da humanidade é normalmente reconhecido como o responsável por grandes e significativos avanços em campos tão críticos quanto diversos, como a alimentação, o transporte, a saúde e a qualidade de vida. Os benefícios propiciados pela tecnologia são absolutamente tangíveis, relevantes e intrinsecamente relacionados com o próprio desenvolvimento científico e civilizatório (CASTELLS, 2006).

No campo do trabalho humano, é histórico o temor pelos efeitos potencialmente destruidores da tecnologia sobre os postos de trabalho, simbolicamente representado pelo movimento ludista ocorrido na Inglaterra no início do século XIX. O ludismo foi um movimento de trabalhadores que utilizou a destruição de máquinas - prática que era comum entre os mineiros ingleses - como forma de pressionar os empregadores contra as condições precárias a que eram submetidos: jornadas exaustivas, ambientes de trabalho insalubres e baixos salários. O cenário se agravava com a introdução de máquinas que causavam demissões e substituição de funções mais qualificadas por outras de pouca exigência técnica e pior remuneradas. O momento histórico era de 
turbulência econômica e desemprego em massa, com inúmeras famílias sendo assoladas pela fome. Questões de competição entre pequenos produtores também se faziam presentes (ROBSBAWM, 1952).

Novamente, a emergência de uma nova revolução tecnológica reacende a polêmica com debates entre visões diametralmente opostas: a daqueles que vislumbram um futuro brilhante, no qual a tecnologia liberta a humanidade da obrigação do trabalho ou ao menos do trabalho duro, repetitivo, desestimulante, ao mesmo tempo que elimina doenças, promove a longevidade, o conforto e o deleite com novas possibilidades lúdicas e sensoriais trazidas por novos e tecnológicos dispositivos, sistemas e ambientes digitais; em posição antagônica, a daqueles que temem as consequências potencialmente nefastas da proliferação da tecnologia de forma intensa por tantos campos sensíveis, como o trabalho, a medicina genética, o controle sobre as informações, sobre os veículos e mesmo sua aplicação no campo militar, criando novos e terríveis cães de guerra. Soma-se ainda o risco da desumanização das relações e da própria consciência humana, num cenário de pós-humanismo cibernético (FUKUYAMA, 2002). O que alimenta estes temores? Embora a informatização tenha sido historicamente confinada a tarefas rotineiras envolvendo atividades baseadas em regras explícitas, a inteligência artificial e os algoritmos para big data agora estão entrando rapidamente em domínios dependentes de reconhecimento de padrões e podem substituir prontamente o trabalho em uma ampla gama de tarefas cognitivas não rotineiras. Somando-se a isso, robôs avançados estão ganhando sentidos aprimorados e destreza, que lhes permitem executar uma ampla variedade de tarefas manuais. Isso provavelmente mudará a natureza do trabalho em empresas e profissões (BRYNJOLFSSON; MCAFEE, 2011). Algumas mudanças já são percebidas. Os avanços nas interfaces de usuário, por exemplo, já permitem que computadores respondam com mais eficiência aos pedidos de clientes, reduzindo a necessidade de intervenção humana em algumas atividades de atendimento e serviços. Com a expansão da capacidade dos computadores, tarefas que já foram consideradas muito complexas para serem codificadas estão sendo convertidas em problemas bem definidos tratáveis através de soluções digitais (OSBORNE; FREY, 2014). Novas aplicações de alto desempenho no reconhecimento de fala e processamento de texto permitem interpretação simultânea, criação automática de textos-padrão complexos, bem como a análise de grandes volumes de texto para fins legais. Em medicina, 
o software inteligente de reconhecimento de imagem pode melhorar significativamente o diagnóstico de muitas doenças e gerar aumento da capacidade produtiva para os médicos e afetar a classe dos clínicos gerais. Na área de cuidados de saúde, estão sendo testados sistemas interativos que podem promover o bem-estar psicológico e emocional de idosos, substituindo em parte o trabalho de assistentes e cuidadores.

Em suma, seja em relação ao trabalho industrial, de serviço ou de conhecimento, a digitalização está mudando todo o sistema sociotécnico de pessoas, organização e tecnologia. Em seus efeitos, há aspectos claramente positivos e outros que inspiram maior reflexão. A figura 1 ilustra a mudança no sistema sociotécnico do trabalho.

Figura 1: Mudança no sistema sociotécnico como resultado da digitalização

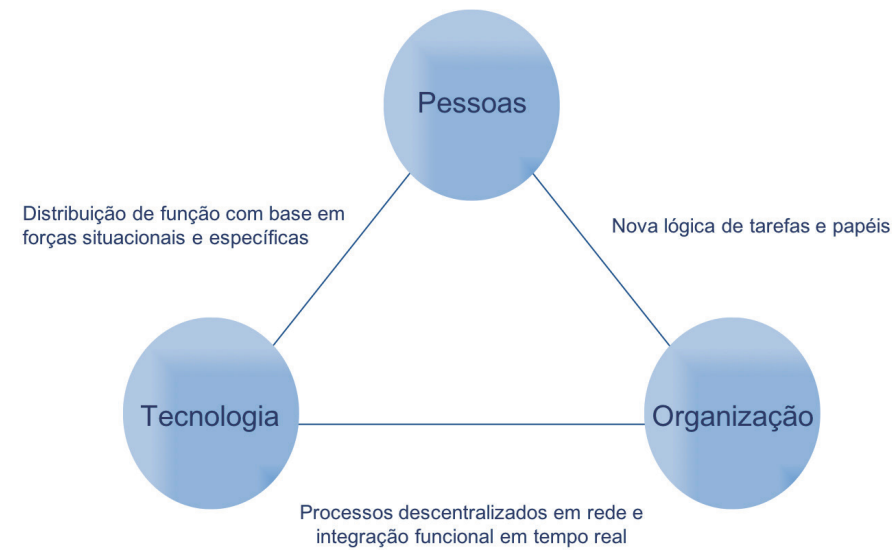

Fonte: BMAS (2017)

$\mathrm{Na}$ interface entre as pessoas e a tecnologia, as novas tarefas serão distribuídas com base nas respectivas forças situacionais e específicas, em que a tecnologia pode ajustar as prioridades e customizar a tarefa para a aplicação específica. Na interface entre organização e tecnologia, os subprocessos hierarquicamente separados, fragmentados, que até então foram executados um após o outro de forma sequencial, são substituídos por procedimentos integrados, simultâneos e descentralizados. Na interface entre homem e organização, surge a questão de adaptar tarefas e distribuir papéis. A mudança na interação homem-máquina abre, assim, novas oportunidades para o redesenho do trabalho e dos processos de produção. Surgem possibilidades para alívio do trabalho rotineiro e repetitivo, para o desenvolvimento das 
habilidades dos funcionários e, mesmo, para a reconciliação da vida privada e trabalho, à medida em que este possa ser tornado mais eficiente, com menor demanda de tempo de dedicação e menos dependência de ciclos de máquinas e equipamentos. O aumento da flexibilização e a organização dos processos em rede abrem oportunidades mais interessantes de interação pessoas-máquinas, permitindo o trabalho mais remoto e alterando em parte a necessidade da presença física constante das pessoas nas instalações das empresas. Esta lógica adveio da revolução industrial, que deslocou o espaço-tempo de trabalho obrigando os indivíduos a agruparem-se em fábricas, em locais fisicamente determinados e em horários pré-estabelecidos (BMAS, 2017).

Um desenho mais apropriado para a era da interação homem-máquina pode contribuir para uma base mais adequada para as operações. Atividades ergonomicamente desfavoráveis podem ser substituídas, aliviando as pessoas da execução de tarefas fisicamente difíceis ou mentalmente estressantes. Desta forma, o estresse físico e mental pode ser reduzido. Mais oportunidades de inclusão no mercado de trabalho surgirão, pois as restrições devido a limitações físicas ou sensoriais podem ser compensadas com a ajuda de sistemas de assistência. As pessoas portadoras de necessidades especiais podem fazer um trabalho mais abrangente. Os trabalhadores mais velhos podem trabalhar mais e de forma mais saudável, o que é uma possibilidade estratégica no atual contexto demográfico, em que vários países estão enfrentando redução de sua força de trabalho por conta do envelhecimento, o que gera efeitos deletérios sobre suas economias (VOGLER-LUDWIG; DÜLL; KRIECHEL, 2016).

O aprimoramento de capacidade produtiva também se aplica à área cognitiva: a disponibilidade constante de informações preparadas com precisão contribui para melhor suporte ao processo de tomada de decisão ao mesmo tempo que possibilita a expansão e maior abrangência das análises e atuações decisórias, se forem suportadas por sistemas de assistência inteligentes. Sistemas de tutoria inteligentes poderiam permitir um nível muito maior de aprendizagem no processo de trabalho. As tarefas de trabalho podem ser projetadas e distribuídas de forma que considerem e promovam sistematicamente a capacidade física e mental de cada indivíduo que trabalha com o sistema autônomo. Essas novas potencialidades estão moldando o mundo do trabalho de amanhã e envolvem a digitalização, novas bases tecnológicas e oportunidades de colaboração, produção, organização dos negócios e dis- 
tribuição de bens e serviços. Vislumbram-se novas possibilidades para um novo tipo de trabalho no futuro: mais produtivo, mais flexível, mais em rede, com possibilidade maior de conectividade internacional. Ao mesmo tempo, criam pressão para a mudança, a necessidade de adaptação e a premência da inovação. Quanto mais percebemos o novo, quanto mais ele se mostra ou pode ser imaginado, mais decisivamente é possível moldá-lo de acordo com os valores e necessidades da nossa sociedade (BMAS, 2017).

\section{Campos de tensão}

A interação com sistemas complexos e cada vez mais autônomos também apresenta desafios para os trabalhadores. A adoção de sistemas e equipamentos tecnológicos avançados modifica a natureza do trabalho humano nas organizações e interfere em várias dimensões do ambiente de trabalho. A amplitude do trabalho pode ter sua complexidade enxugada até o ponto em que o humano se torna assistente da máquina e passa a realizar apenas tarefas complementares em que ela ainda seja improdutiva. Tal condição restringiria aos indivíduos a capacidade de desenvolver visão sistêmica e reduziria o significado do trabalho e o seu propósito, empobrecendo o processo de aprendizagem à medida em que habilidades específicas não seriam mais desenvolvidas pelas pessoas, gerando perda de conhecimento prático. Uma forma de opressão digital poderia se instituir, dadas as imensas possibilidades de monitoramento e controle do desempenho dos trabalhadores, numa alegoria literária, tal qual descrito no romance distópico "Mil novecentos e oitenta e quatro”, publicado em 1949 pelo inglês George Orwell (ORWELL, 2004).

O risco de substituição permanente do trabalho humano pelas máquinas e sistemas interfere na questão da motivação dos trabalhadores, pois abala as suposições de estabilidade no emprego e, consequentemente, de garantia da renda e do sustento. Maslow, em sua teoria sobre as necessidades humanas e a motivação dos indivíduos, coloca a questão da segurança como sendo um dos requisitos básicos para a satisfação das necessidades humanas (SENGUPTA, 2011). A figura 20 indica as áreas de tensão que surgem a partir do contexto da digitalização e automação intensa dos processos de trabalho e operações. 
Figura 2: Campos de tensão para o trabalhador diante do avanço da digitalização do ambiente de trabalho.

Fonte: os autores

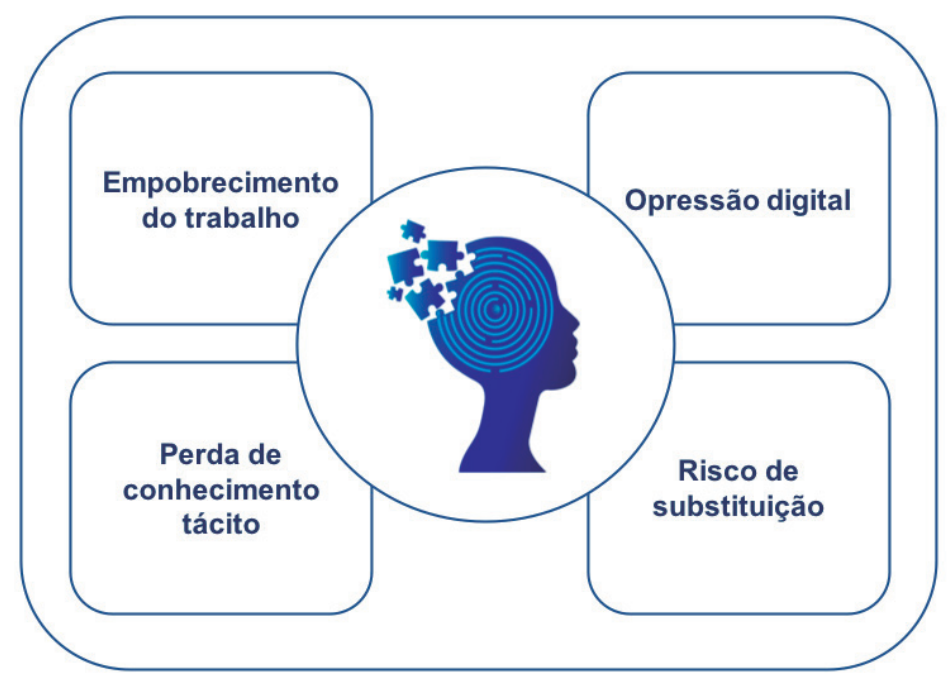

\section{Empobrecimento do trabalho}

A interação pessoas-máquina pode tanto enriquecer as atividades para os funcionários, tornando-as mais integradas e significativas, como depreciá-las, conforme o modelo que seja adotado. O desenho do trabalho pode definir o uso dos sistemas para fornecer assistência para o indivíduo lidar com as novas complexidades. Também pode partir do princípio da simplificação e normalização exaustiva dos processos, tornando reduzida a possibilidade de aplicação do conhecimento e da experiência pelas equipes de trabalho (BMAS, 2017). Situações em que o funcionário segue apenas sinais ou comandos emitidos pelo próprio sistema tornariam o trabalho enfadonho e pouco significativo. Processos desenhados com automação excessiva, que buscam eficiência extrema, podem acabar por delegar apenas atividades residuais e monótonas aos trabalhadores, retirando o sentido do trabalho e destruindo a motivação de fazê-lo. Seria uma espécie de taylorismo digital, uma volta às origens da administração científica, cujos princípios fundamentais são a especialização, a padronização das tarefas, a divisão do trabalho em tarefas simples e capazes de uma execução que não demande qualificação profissional sofisticada, entre outras (TAYLOR, 1990). 


\section{Perda do conhecimento tácito}

Um segundo campo de tensão diz respeito à importância do conhecimento baseado na experiência. À medida que o papel dos humanos é cada vez mais reduzido para mera supervisão dos processos automatizados, dificilmente os funcionários desenvolverão competência para operá-los, analisá-los criticamente e mesmo melhorá-los. O chamado conhecimento tácito, aquele que é fruto da experiência, adquirido pelo exercício da prática recorrente, termina por não se desenvolver nas equipes de trabalho, o que gera tanto dependência excessiva dos sistemas automatizados quanto esvaziamento da capacidade destas equipes de otimizar seus processos. O quadro 1 apresenta uma experiência desenvolvida na Toyota no Japão em que pessoas são reintroduzidas no trabalho de linhas de montagens para que possam identificar oportunidades de melhoria nos processos produtivos (TRUDELL; HAGIWARA; JIE, 2014). Experiência similar foi desenvolvida numa fábrica da Mercedes, em que a empresa entendeu que algumas atividades que haviam sido automatizadas deveriam novamente ser feitas por pessoas, inclusive para que a empresa não perdesse seu know how e pudesse ter certa flexibilidade em situações de falha de equipamentos (GIBBS, 2016).

Quadro 1: Experiência na linha de montagem da Toyota.

\section{O caso da Toyota}

Os fabricantes de automóveis adotam a automação e substituem humanos por robôs em suas linhas de montagens há muitos anos. Mas a Toyota, maior fabricante mundial de veículos, está literalmente dando um passo para trás e substituindo máquinas automatizadas em algumas fábricas no Japão e criando linhas de produção com razoável participação manual de pessoas.

É uma escolha não convencional para uma empresa japonesa. O Japão concentra, de longe, o maior número de robôs industriais do mundo: mais de trezentos mil. A noção de colocar pessoas de volta ao comando das linhas de montagem é contra intuitiva porque os robôs se tornaram muito eficientes em fazer as tarefas repetitivas com precisão absoluta e estão presentes na maior parte das atuais linhas de montagens automatizadas. Entretanto, em oposição à velocidade, precisão, baixo custo de produção e repetibilidade que os caracterizam, os robôs industriais não conseguem sugerir e encontrar formas de melhoria. Na visão dos gerentes da Toyota, a única maneira de melhorar os processos e promover mais reflexão sobre sua eficiência é colocar as pessoas de volta e fazê-las vivenciar a prática do kaizen, componente essencial do modelo de 
gestão da Toyota, chamado Sistema Toyota de Produção, que prescreve a abordagem de melhoria contínua a partir do acompanhamento intenso, observação e realização das tarefas, como subsídio para que as equipes possam redesenhar os processos em busca de ganhos de qualidade e eficiência. O chefe deste projeto, Mitsuru Kawai, afirma que as pessoas que retomaram o trabalho realizado por robôs em mais de cem espaços de trabalho reduziram o desperdício na produção em $10 \%$ e ajudaram a encurtar o tempo de processo.

Fonte: Trudell; Hagiwara; Jie (2014). Elaborado pelos autores.

\section{Opressão digital}

Os mesmos dados que inicialmente são gerados para controle dos processos, equipamentos e máquinas podem ser utilizados para controle do desempenho das pessoas e mesmo controle comportamental. À medida em que pessoas e máquinas trabalham mais conectadas e em rede, é mais possível controlar e documentar informações sobre localização, desempenho e comportamento das pessoas. Em aplicações específicas, os robôs devem reagir ao comportamento de um trabalhador, movendo-se, por exemplo, para evitar choques e lesões. Isto requer, além de sensores apropriados, dados sobre os movimentos e a localização do trabalhador. Armazéns automatizados devem saber quanto tempo os trabalhadores despendem para retirar itens de seus locais de armazenamento. As luvas inteligentes somente podem ser úteis se determinados dados estiverem disponíveis sobre o funcionário e a ordem de trabalho. O que se tornará realidade em termos de configuração do trabalho no futuro dependerá não somente de aspectos de viabilidade técnica e rentabilidade financeira, mas também de negociação e estruturação social (BMAS, 2017).

Numa escala menor, dependerá das políticas e opções de arranjo que cada organização decidir estabelecer. A tipologia provável deve se resumir em duas configurações. Na empresa do tipo “arranjo centrado na tecnologia”, a participação humana seria reduzida a atividades que não fossem passíveis de automação por razões técnicas, econômicas ou éticas, como, por exemplo, algumas atividades de cuidado com a saúde. Nessas empresas, haveria uma distinção bem marcante entre um pequeno contingente de pessoas simples, porém bem qualificadas para as funções operacionais e de apoio aos processos, e uma elite profissional fortemente focada em planejamento e controle 
com qualificação profissional num nível bem superior ao primeiro grupo. Na empresa do tipo “arranjo centrado na colaboração”, as pessoas exerceriam sua autoridade criativa, decisória e experimental, trabalhando em rede, divididas em equipes tecnicamente niveladas, menos distintas entre si, em que a separação entre o planejamento e controle e a execução ocorreria de maneira suave e quase superada, com todos atuando de forma sinérgica e complementar, apoiados por ferramentas inteligentes e sistemas avançados de assistência e mesmo redes de robôs colaborativos. O quadro 2 indica a tipologia possível num ambiente de uso intenso de tecnologia.

Quadro 2: Tipologia de organizações que fazem uso intensivo da tecnologia digital em seus processos de trabalho.

\begin{tabular}{|c|c|c|c|}
\hline $\begin{array}{c}\text { Tipo } \\
\text { de empresa }\end{array}$ & $\begin{array}{c}\text { Foco } \\
\text { determinante }\end{array}$ & $\begin{array}{c}\text { Distriuição } \\
\text { de funções }\end{array}$ & $\begin{array}{c}\text { Perfil } \\
\text { da equipe }\end{array}$ \\
\hline $\begin{array}{c}\text { Arranjo centrado na } \\
\text { tecnologia }\end{array}$ & Tencologia & $\begin{array}{c}\text { Divisão clara entre } \\
\text { planejamento e controle e } \\
\text { execução }\end{array}$ & $\begin{array}{c}\text { Hierárquico, desigual, com } \\
\text { alto grau de divisão de } \\
\text { classes }\end{array}$ \\
\hline $\begin{array}{c}\text { Arranjo centrado na } \\
\text { colaboração }\end{array}$ & Colaboração & $\begin{array}{c}\text { Funções compreendem } \\
\text { planejamento, controle e } \\
\text { execução }\end{array}$ & $\begin{array}{c}\text { Homogêneo, com } \\
\text { atuação complementar, } \\
\text { colaborativa e em rede }\end{array}$ \\
\hline
\end{tabular}

Fonte: Os autores.

A opção por um dos tipos determinará as escolhas essenciais que a organização fará em termos do desenho da sua operação, incluindo a forma de estruturação conceitual e desenho dos seus processos, o tipo de equipamento, maquinário, robôs e sistemas que serão adquiridos, o arranjo físico e mesmo o tipo de mobiliário, as políticas de remuneração, a estrutura organizacional, a estrutura de cargos e salários, o estilo de liderança e o perfil da sua força de trabalho.

\section{Risco de substituição}

Existe uma crescente polarização das oportunidades no mercado de trabalho entre empregos de alta e baixa habilidade e remuneração, desemprego e subemprego, estagnação dos rendimentos de uma grande proporção de famílias e desigualdade de renda (ANTUNES, 2006; PIKETTY, 2015; MGI, 2016). O desenvolvimento da automação habilitada por tecnologias como a robótica e a inteligência artificial traz a promessa de maior produtividade, crescimento econômico, eficiência, segurança e conveniência. Entretanto, 
essas tecnologias levantam questões difíceis sobre o impacto da automação nos empregos, nos salários, nas habilidades requeridas e na própria natureza do trabalho em si. Muitas atividades que são realizadas atualmente têm potencial para serem automatizadas (MGI, 2017a). Os trabalhos de menor qualificação, incluindo os serviços administrativos, possuem alto risco de substituição pela tecnologia.

\section{Transformações nas organizações}

As empresas e outras organizações estão também sendo afetadas pelas mudanças nas condições da economia e do trabalho geradas pela transformação digital: mudanças tecnológicas, inovação acelerada, alterações nas cadeias de fornecimento, mudança na arquitetura dos processos produtivos, surgimento de serviços baseados em grandes dados, entre tantas. Novas possibilidades e rumos no atendimento dos desejos dos clientes estão transformando processos de criação de valor e colocando demandas inteiramente novas para a organização mais flexível do trabalho humano e sua interação com sistemas e máquinas. Empresas e organizações são os espaços onde todas essas mudanças se amalgamam e se concretizam. A típica estrutura organizacional - vertical, hierárquica, preparada para produzir baseada em padronização, com portfólio rigidamente definido e busca permanente por maior escala - já vinha mudando ao longo dos anos ao adotar novos modelos e práticas de gestão como o lean manufacturing, a gestão da qualidade total, a gestão por processos, entre outros sistemas e técnicas de gestão (SLACK; CHAMBERS; JOHNSTON, 2009; CORREAA; CORREAA, 2017; CAMPOS, 1990). Diferentes modelos e possibilidades para conduzir a organização com sucesso aos seus propósitos podem ser aplicáveis. Sua escolha depende das suas características intrínsecas, contextos, porte, ramo de atuação, estilo e opções estratégicas. Algumas prezam pela estruturação rígida de processos, controles e planejamento, enquanto outras apoiam-se no trabalho de grupos criativos e mais informais, ou mesmo na condução inspiradora de líderes diferenciados (MASI, 2000).

O momento atual sugere transformações radicais em termos organizacionais, com a possível utilização de estruturas e ambientes colaborativos, intensidade de interfaces pessoas-máquinas, uso intenso da virtualização como recurso de desenvolvimento e análise de produtos, serviços e proces- 
sos, atuação interna e externa em redes, foco mais acentuado na geração de valor aos clientes e usuários. No campo da manufatura, o modelo das fábricas inteligentes é bem representativo das novas configurações possíveis.

\section{Transformações nos mercados de trabalho e nas sociedades}

A discussão sobre o impacto dos robôs e da automação ganhou novas proporções quando os pesquisadores Carl Benedikt Frey e Michael Osborne da Universidade de Oxford publicaram um trabalho científico em 2013 que envolveu a análise de mais de setecentas ocupações de trabalho no Reino Unido e a probabilidade de serem automatizadas nos próximos vinte anos, ou seja, quais as chances dos trabalhadores que atuam nestas profissões serem substituídos por máquinas inteligentes. O estudo apontou que 35\% dos trabalhadores do Reino Unido estão em risco de serem substituídos por máquinas nos próximos vinte anos. Com base neste mesmo estudo, há previsões de que metade dos empregos da União Europeia esteja ameaçada (OSBORNE; FREY, 2013).

Para classificar o grau de risco de automatização das ocupações, os pesquisadores consideraram algumas habilidades críticas que dificilmente podem ser incorporadas por máquinas e sistemas de inteligência artificial no atual estágio de evolução:

- Habilidade de percepção: entendimento de um contexto complexo, mesmo que subjetivo.

- Manipulação: especialmente de objetos irregulares.

- Criatividade: envolve a capacidade de inovação, a criação estética e artística, a criação de soluções para desafios não programados.

- Inteligência social: envolve a combinação de habilidades de negociação, persuasão, empatia e cuidado com o outro (OSBORNE; FREY, 2013).

As estimativas para os EUA sugerem que 47\% da força de trabalho estejam em risco. Entre os aspectos já nítidos, estão a mudança da demanda em termos do nível de qualificação do profissional e as diferentes probabilidades de substituição tecnológica a que as atuais profissões estão sujeitas. Os avanços na tecnologia estão tornando uma ampla gama de tarefas não rotineiras automatizáveis, permitindo principalmente a substituição de 
trabalhadores de baixa renda e baixa habilidade nas próximas décadas. A função de operador de telemarketing tem 99\% de chance de desaparecer. Já a de assistente social tem apenas 0,3\% de probabilidade de substituição (BRYNJOLFSSON; MCAFEE, 2011). A figura 3 mostra a probabilidade de automação de algumas funções.

Figura 3: Probabilidade de automação para doze diferentes ocupações nas maiores economias. Em milhares de trabalhadores.

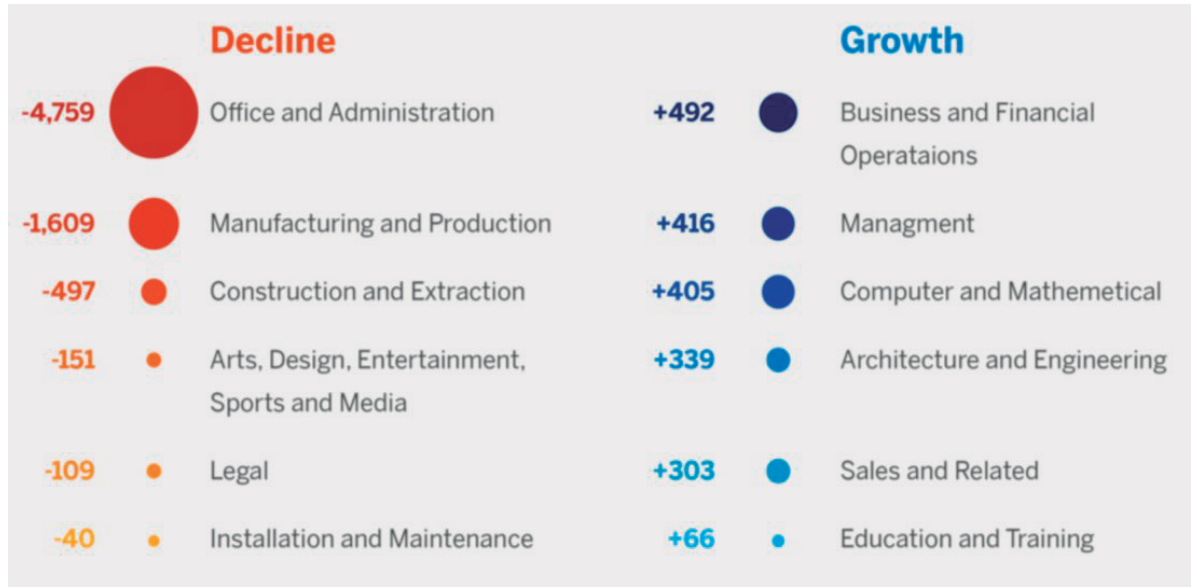

Fonte: WEF (2016).

\section{Baixa qualificação, alto risco}

Diferentemente de outros movimentos históricos semelhantes, a nova revolução digital impactará fortemente as ocupações de baixa renda e menor qualificação, em função das suas características tecnológicas. Pesquisa realizada em Londres aponta que um em cada três empregos corre risco de ser redundante pela tecnologia nos próximos 10 ou 20 anos. Em relação aos empregos de baixa remuneração, 63\% estão classificados na categoria de alto risco de substituição (OSBORNE; FREY, 2013). O gráfico 1 indica o risco de substituição para algumas ocupações. 


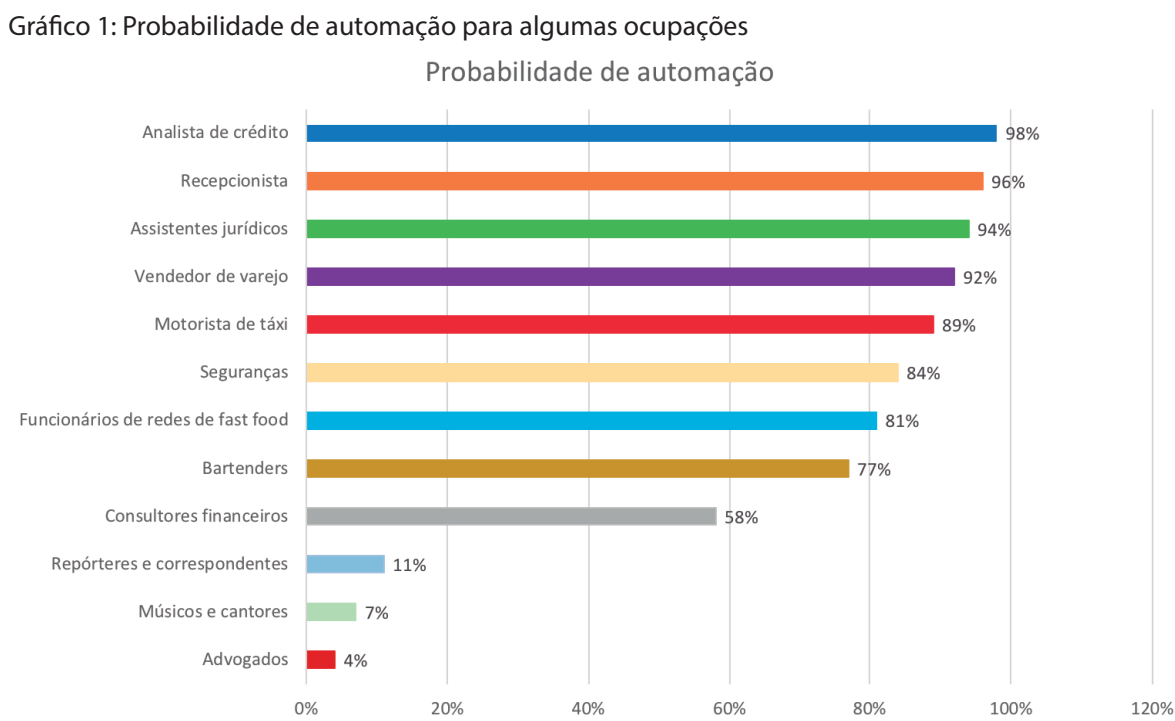

Fonte: WEF (2015). Elaborado pelos autores.

Por outro lado, ocupações que envolvem maior qualificação apresentam menor risco de substituição, sendo que algumas terão forte expansão da sua demanda. O Department of Labor do governo dos Estados Unidos afirma que 11 das 15 ocupações com previsão de maior expansão em número de postos de trabalho até o ano de 2024 tem como requisito de entrada nível superior de educação (BLS, 2017). Na Alemanha, os estudos que preveem expansão do PIB e crescimento do número de postos de trabalho com a implantação da Indústria 4.0 no país consideram que a oferta de mão de obra do cenário básico não será suficiente para cobrir a demanda por mais 530 mil profissionais qualificados com nível de educação superior até 2030. Neste número, incluem-se 170 mil bacharéis em direito, economia e sociologia, $140 \mathrm{mil}$ engenheiros, 90 mil matemáticos e cientistas, assim como 70 mil cientistas sociais e bacharéis em letras, além de 30 mil historiadores e graduados no estudo das artes. O desafio será enfrentar a redução dos postos de trabalho ocupados por trabalhadores de baixa escolaridade e qualificação. Em 2014, havia um total de 7,8 milhões de pessoas com este perfil profissional na Alemanha. Acredita-se que 2 milhões de trabalhadores serão redundantes com a tecnologia até 2030 (VOGLER-LUDWIG; DÜLL; KRIECHEL, 2016). 


\section{Diferença entre setores econômicos}

A estratégia de digitalização acelerada vai estimular um crescimento mais forte em alguns setores específicos da economia alemã. O setor de tecnologia de informação precisará de 120.000 adicionais até 2030, um crescimento de 17\% em relação a 2014. Também profissões ligadas às áreas de vendas, engenharia mecânica, propaganda e marketing, mídia, compras, serviços financeiros, construção civil e serviços públicos se beneficiam. Por outro lado, o setor de varejo, setor gráfico e de fabricação de papel e administração pública terão queda no número de postos de trabalho. Um total de 27 setores da economia alemã terá diminuição da sua força de trabalho, com uma perda estimada de 750 mil empregados. As maiores perdas relativas acontecerão na indústria têxtil, no setor de vestuário e couro, mineração, telecomunicações, setor gráfico e fabricação de papel (VOGLER-LUDWIG; DÜLL; KRIECHEL, 2016).

\section{Impactos diferentes nos países}

O impacto da digitalização sobre a economia e sobre o mercado de trabalho será diferente para cada país. Uma pesquisa feita pela Universidade de Oxford em parceria com o Citibank em janeiro de 2016 aponta a China, Índia e Tailândia como sendo os países potencialmente mais afetados em termos do risco de substituição do trabalho humano por conta da automação (BRYNJOLFSSON; MCAFEE, 2011).

A automação orientada pela inteligência artificial pode ampliar a divisão internacional do trabalho, aumentando a defasagem econômica das nações mais pobres e tecnicamente atrasadas. Países que esperam um crescimento rápido da sua população e têm contado com um modelo de desenvolvimento econômico intensivo em mão de obra podem enfrentar novas ondas de agitação social, pois grandes segmentos da população perdem seus empregos para as máquinas (MGI, 2017d).

O mapa do impacto da tecnologia sobre os empregos não terá uma configuração baseada na geografia ou na tradicional divisão entre países de economia desenvolvida e em desenvolvimento - países emergentes. Ele se baseará num conjunto e combinação de fatores, que incluem: o potencial industrial de cada um, o perfil de participação de cada setor da economia no 
PIB (agrícola, industrial e serviços), o nível educacional da força de trabalho, a capacidade de requalificar sua força de trabalho para os requisitos do ambiente digital e da Indústria 4.0, a estrutura demográfica do país, seu grau de desenvolvimento tecnológico e de inovação, a disponibilidade dos recursos necessários para adequar sua infraestrutura e garantir os investimentos necessários para a transformação, assim como a capacidade de organizar e gerenciar o processo de mudança (EUROPEAN COMMISSION, 2012; KAGERMANN; WAHLSTER; HELBRIG, 2013; WEF, 2016; RANDER, 2016). A figura 4 indica os impactos previstos na força de trabalho de alguns países.

Figura 4: Disrupturas no mercado de trabalho.

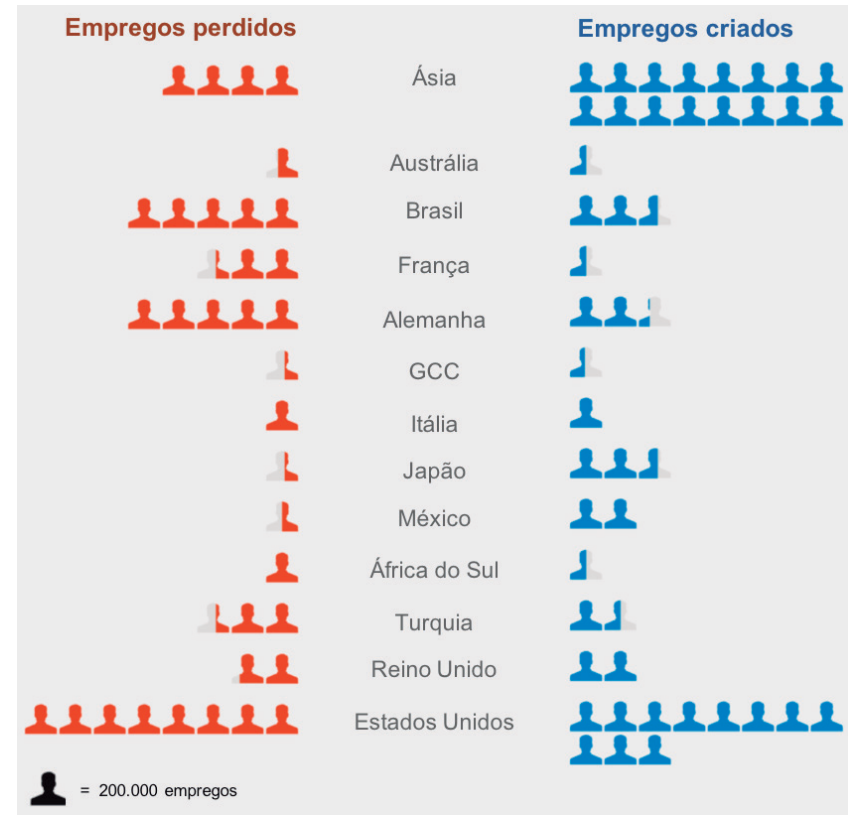

Fonte: WEF (2016). Adaptado pelos autores.

\section{Impactos diferentes em cidades}

A cidade é a divisão administrativa e o espaço de viver onde a realidade se coloca de forma concreta aos indivíduos. No âmbito dos estados e da própria federação, a dimensão dos fenômenos é composta ora por um somatório, ora por uma média. É claro que as políticas e as decisões tomadas nestas esferas definem o contexto e certas condições determinantes; entretanto, é no espaço local que a realidade se tangibiliza de forma úni- 
ca. De acordo com seu perfil técnico-econômico e cultural, cada cidade sofrerá seu próprio impacto com a revolução tecnológica que se desdobra. Por exemplo, o risco geral de substituição de empregos nos EUA nos próximos vinte anos é de 47\%. As cidades com maior risco são Las Vegas e Fresno na Califórnia, esta com 54\%. Já a suscetibilidade à automação das cidades de Washington, New York e Boston é de 38\% (BRYNJOLFSSON; MCAFEE, 2011).

As divisões podem acontecer mesmo entre regiões costeiras mais prósperas e regiões interiores menos desenvolvidas, assim como entre áreas urbanas e rurais. Considerar essas possibilidades será uma parte vital do planejamento para um futuro que inclua um papel importante para as tecnologias de inteligência artificial (MGI, 2017d).

No Reino Unido, a estimativa geral é que 35\% das ocupações apresentam alto risco de substituição pela tecnologia. O risco para Londres é 30\%, sendo que 19\% dos empregos apresentam risco médio e 51\% dos empregos apresentam risco baixo de extinção. A grande proporção de empregos de Londres na categoria de baixo risco reflete a especialização da cidade em habilidades sociais e criativas. Com alta densidade populacional num ambiente de forte interação social e de intercâmbio de ideias, Londres já é um centro para empregos mais qualificados do que outras cidades líderes em todo o mundo e possui o maior número de pessoas que trabalham em indústrias baseadas no conhecimento (OSBORNE; FREY, 2014). A figura 5 apresenta uma comparação do número de empregos de alta qualificação em algumas das principais cidades do mundo.

Figura 5: Número de empregos altamente qualificados nas principais cidades do mundo, 2013

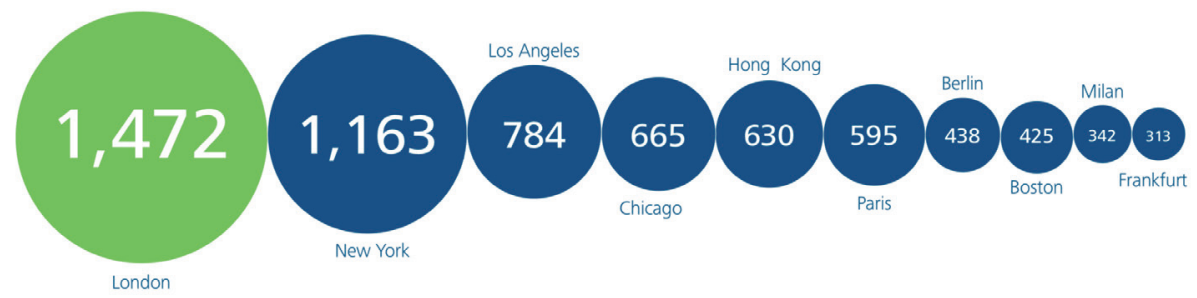

Fonte: Deloitte (2015).

O ritmo da automação e seus impactos nos trabalhadores variará em diferentes atividades, ocupações e níveis de salário e habilidades. Alguns países sofrerão impactos maiores do que outros; assim como no âmbito das 
cidades, os efeitos da transformação serão diferentes. Esta desproporção dos efeitos certamente desencadeará desafios para as cidades e países em termos de novos fluxos migratórios e imigratórios, desequilíbrios regionais, pressão sobre os serviços públicos e sobre os sistemas de proteção social.

Os fatores que determinarão o ritmo e a extensão da automação incluem o desenvolvimento contínuo das capacidades tecnológicas, o custo da tecnologia, a concorrência e qualificação da mão de obra disponível, a dinâmica da oferta e da demanda, os custos trabalhistas, as restrições regulatórias, condicionantes legais e a própria aceitação social e capacidade de liderança e condução da mudança. Os cenários sugerem que metade das atividades de trabalho de hoje poderia ser automatizada até 2055, com um intervalo de tolerância de mais ou menos 20 anos (MGI, 2017b).

A divergência nas taxas de adoção de novas tecnologias explica, em parte, a diferença de padrão de renda entre países ditos ricos e pobres, desde a Revolução Industrial (BRYNJOLFSSON; MCAFEE, 2011). Os efeitos da automação podem ser lentos em um nível macro, em setores ou mesmo em economias inteiras, mas bastante rápidos em nível micro, para as pessoas cujas atividades são automatizadas ou para empresas cujas operações são interrompidas por concorrentes que adotem a automação avançada mais rapidamente (MGI, 2017b).

\section{O futuro brilhante}

Em termos dos efeitos sobre o emprego, a tecnologia, nos últimos 150 anos, por mão das suas revoluções, levou à criação de postos de trabalho e expansão da economia (STEWART; COLE, 2015). A automação e o progresso tecnológico não tornaram o trabalho humano obsoleto: a relação emprego-população aumentou durante o século XX e, embora a taxa de desemprego flutue ciclicamente, não há tendência aparente a longo prazo (OSBORNE; FREY, 2013).

O futuro ainda está sendo construído. Importantes economias mundiais, como Alemanha, Inglaterra e Estados Unidos, desenvolveram estudos e planos para se prepararem para as transformações desta revolução tecnológica. Bélgica, Suécia e Áustria também desenvolvem planos e ações de adequação de sua indústria. O sucesso de suas iniciativas definirá o impacto das mudanças sobre suas respectivas economias e mercados de trabalho (EURO- 
PEAN COMMISSION, 2012; KAGERMANN; WAHLSTER; HELBRIG, 2013; HOLDREN; LANDER, 2014; THINK ACT, 2015).

Na Alemanha, alguns críticos da pesquisa conduzida por Carl Benedikt Frey e Michael Osborne, da Universidade de Oxford, alegam que o seu prognóstico para eliminação de postos de trabalho por conta da automação é controverso, pois implica que tudo o que teoricamente pode ser automatizado será automatizado. Na sua crítica, alegam que somente é possível automatizar determinadas tarefas ou processos e não necessariamente profissões inteiras. Assim, segundo seu próprio modelo de previsão, a porcentagem de funcionários que trabalham hoje em empregos altamente vulneráveis na Alemanha seria de $12 \%$ e não 42\%, como sugere Osborne e Frey. Em suas projeções, a força de trabalho na Alemanha em 2030 será aproximadamente a mesma de 2014, em termos quantitativos. Tal fato se relaciona com a questão demográfica (envelhecimento da população e aposentadoria) e também com a questão migratória. Estes dois fenômenos interferem significativamente na variação do PIB e da força de trabalho da Alemanha (BMAS, 2017). Considerando que a Alemanha tenha sucesso nos esforços de integração e qualificação dos imigrantes, enquanto força de trabalho capaz de contribuir para a atenuação dos efeitos da redução da população, assim como nas iniciativas já em vigor para preparar a indústria e a economia alemã para a Indústria 4.0, a digitalização acelerada poderia proporcionar aumento da produtividade e crescimento do PIB. O crescimento anual da produtividade no cenário de adoção acelerada da digitalização é de 0,8 a 1,4\% (MGI, 2017b).

Em termos de emprego, num cenário de adoção acelerada da digitalização, a perda de 750 mil empregos por conta da substituição tecnológica seria compensada com a criação de um milhão de empregos até 2030 nos setores que serão favorecidos pela transformação econômica gerada pelos investimentos e adoção da Indústria 4.0 (BMAS, 2017).

Esta abordagem considera não apenas os riscos potenciais colocados pela digitalização, mas leva em conta os efeitos positivos da demanda que será gerada pela inovação de produtos, redução dos custos e preços. O produto interno bruto alemão em 2030 é estimado 4\% maior do que seria sem a estratégia de adoção acelerada da digitalização conduzida pela iniciativa Industrie 4.0. O desemprego cairá em $20 \%$ e os rendimentos per capita serão $4 \%$ maiores. A implantação da digitalização acelerada, por sua vez, implicará num declínio maior do emprego no período entre 2025 e 2030, quando 
100.000 postos adicionais serão eliminados na Alemanha por conta da racionalização, se comparado ao cenário de crescimento orgânico da digitalização da economia. Entretanto, considerando a queda no estoque de mão de obra (por questões demográficas), os efeitos da racionalização servirão para aliviar a escassez, garantindo que haja alto crescimento econômico apesar da redução quantitativa da força de trabalho. Os cálculos do modelo mostram que o uso estratégico e ativo da tecnologia digital será capaz de gerar notáveis efeitos positivos no crescimento econômico e no emprego. Os receios de que seja outra onda de desemprego tecnológico são infundados. Portanto, não é apenas uma ameaça para os empregos existentes, mas uma base para criação de novos (VOGLER-LUDWIG; DÜLL; KRIECHEL, 2016).

Várias tendências podem potencializar a demanda por mão de obra e gerar milhões de empregos até 2030. Estas tendências incluem a necessidade de serviços para cuidar de pessoas nas sociedades em envelhecimento, o desenvolvimento de produtos e de infraestrutura ligados às energias renováveis e ao aumento da eficiência energética (por conta dos desafios climáticos), a expansão do consumo nos países em desenvolvimento e também os investimentos em tecnologia, em infraestrutura e construção civil necessários em todos os países (MGI, 2017c).

Com o aumento da proporção da população mundial nas faixas etárias mais elevadas, mais pessoas estão se aposentando em diversos países. Como resultado, prevê-se que a taxa de participação da força de trabalho na economia diminua. No Japão, por exemplo, a população de 128,6 milhões de 2010 deverá cair para menos de 86,74 milhões até 2060 (HELPAGE, 2015; BLS, 2017). Nos EUA, a desaceleração do crescimento da força de trabalho é esperada e deve refletir numa taxa de crescimento do produto interno de 2,2\% ao ano ao longo da década. Esse crescimento econômico é projetado para gerar 9,8 milhões de novos empregos - um aumento de 6,5\% entre 2014 e 2024. As projeções são baseadas em premissas, incluindo uma taxa de desemprego de $5,2 \%$ em 2024 e crescimento da produtividade laboral de 1,8\% ao ano em relação ao período projetado (BLS, 2017). A figura 6 mostra a evolução do número de pessoas com mais de 60 anos em algumas das maiores economias do mundo (IMF, 2017; HELPAGE, 2015). 
Figura 6: Comparação entre países: proporção de pessoas com mais de 60 anos de idade (\%).

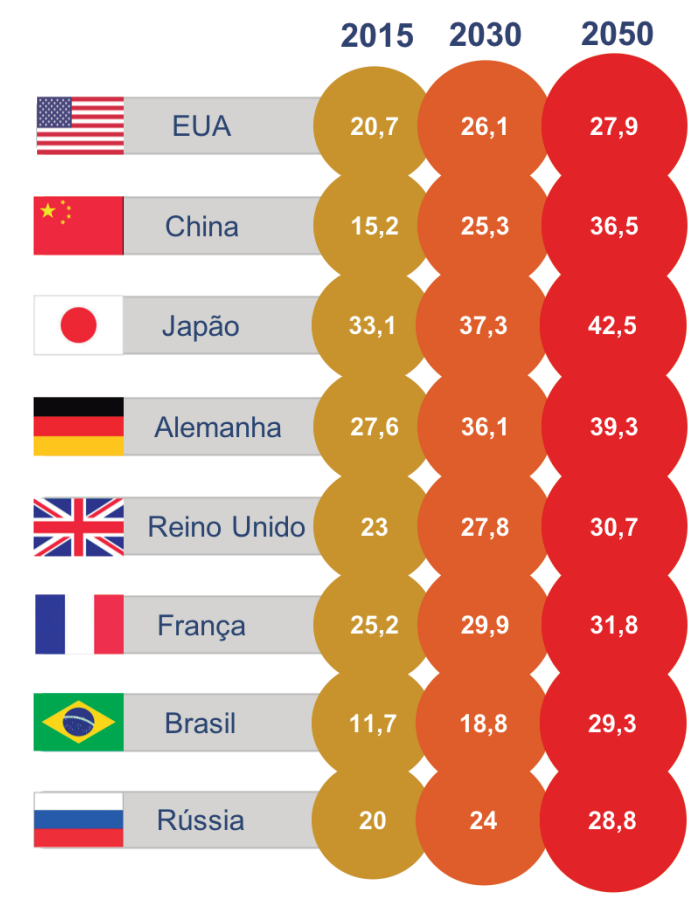

Fonte: IMF (2017) e Helpage (2015). Elaborado pelos autores.

Com a redução evidente da população economicamente ativa nas principais economias do mundo, a tendência de queda nos produtos internos brutos pode ser aliviada por um aumento da produtividade. A digitalização da economia pode trazer este benefício se empreendida com sucesso. Para países como a Alemanha, por si só o ganho de produtividade esperado com a digitalização não é suficiente para compensar a queda no PIB. A integração dos imigrantes à força de trabalho é o segundo elemento decisivo para que a economia alemã possa continuar a crescer.

No período de 2000 a 2014, a migração proporcionou cerca de 40\% do crescimento da força de trabalho no Canadá, Espanha, Reino Unido e Estados Unidos. Os migrantes tiveram uma contribuição para a produção global de cerca de US\$ 6,7 trilhões, ou 9,4\% do PIB global em 2015. No entanto, os trabalhadores migrantes, em média, ganham salários que são entre 20 a $30 \%$ inferiores aos dos trabalhadores nativos. Abordagens de integração mais eficazes poderiam lançar as bases para ganhos econômicos de até US\$ 1 trilhão a nível mundial, beneficiando economias e indivíduos (MGI, 2017a). 


\section{Novos empregos surgirão}

Cerca de um terço dos empregos criados nos Estados Unidos nos últimos vinte e cinco anos não existia ou era pouco expressivo em áreas como desenvolvimento de tecnologia da informação, fabricação de hardware, desenvolvimento de aplicativos, gerenciamento de sistemas de TI, segurança da informação, web design, SEO (search engine optimization), desenvolvimento de games etc. $\mathrm{O}$ impacto das tecnologias emergentes pode ser fortemente positivo para os empregos (MGI, 2017a). Além de 2025, novas indústrias e funções de trabalho serão criadas, mas são difíceis de prever, como, no passado, era difícil prever smartphones e redes sociais como temos atualmente. A automação tem impulsionado a produtividade e os retornos do capital e do trabalho há 200 anos (TRUDELL; HAGIWARA; JIE, 2014). A Internet foi responsável por 21\% do crescimento do PIB nos últimos cinco anos nos países desenvolvidos. Entre as 4,8 mil pequenas e médias empresas pesquisadas, a Internet criou 2,6 postos de trabalho para cada emprego perdido devido a eficiências relacionadas com a tecnologia (MGI, 2011). Na França, a Internet contribuiu para que 500 mil empregos fossem destruídos entre 1985 e 2000. No mesmo período, por outro lado, ajudou a criar 1,2 milhões de outros, uma relação de 2,4 empregos criados para cada emprego destruído. O crescente papel do big data na economia e nos negócios criará a necessidade de aporte significativo de estatísticos e analistas de dados, estimado em 250.000 cientistas apenas nos Estados Unidos na próxima década. A tecnologia digital também estimulará novas formas de atividade empresarial. Empreendedores e trabalhadores em pequenas empresas e profissões autônomas podem se beneficiar de maiores oportunidades de trabalho e renda (MGI, 2017a).

\section{Robôs podem trabalhar de forma colaborativa}

A despeito dos temores pela intensificação do uso de robôs nas fábricas inteligentes, as empresas estão explorando as opções de uso dos cobots ou robôs colaborativos. Esta nova geração de robôs possui dois braços que atuam de forma sincronizada, o que lhes confere novas possibilidade de manuseio e movimento de pequenas partes ou peças. Incorpora a capacidade de "enxergar" - através de câmeras acopladas - e localizar seus objetos de interesse ajustando a amplitude dos seus movimentos. São equipados com 
sensores de toque e aproximação que evitam que se choquem com os humanos com os quais trabalham de forma colaborativa em células de produção. A ideia é somar e combinar as habilidades mais fortes de humanos e robôs de forma a melhorar a eficiência da operação e mesmo libertar os indivíduos de parte de movimentos desgastantes ou repetitivos (ABB, 2018). Robôs são consistentes, confiáveis e não se cansam, mas não improvisam bem. As mudanças nas linhas de montagem exigem uma reprogramação minuciosa pelos humanos. A solução é conciliar inteligência artificial para orquestrar os processos produtivos, programando robôs e distribuindo tarefas aos humanos que trabalham ao lado deles (MCDERMOTT, 2018).

Numa fábrica da Mercedes-Benz, alguns dos seus robôs foram trocados por pessoas mais capazes em suas linhas de montagem. Os robôs não conseguem lidar com o ritmo das mudanças e com a complexidade das principais opções de personalização de alguns produtos comercializados pela empresa. Nestes casos, é possível reduzir os custos empregando pessoas no lugar de robôs. A indústria automotiva é a maior usuária de robôs industriais, responsável por cerca de 100.000 das unidades embarcadas em 2014. Na busca por um padrão de produtividade que permita gastar 30 horas para produzir um veículo (em 2005 a empresa gastava 61 horas), a Mercedes-Benz está utilizando uma configuração de trabalho que denominou de "agricultura robótica”: pessoas trabalhando assessoradas por uma variedade de máquinas menores e mais leves e robôs colaborativos. A Mercedes, segundo maior fabricante mundial de carros de luxo, não está sozinha nesta mudança para sistemas mais flexíveis. Os concorrentes alemães BMW e Audi também estão testando robôs equipados com sensores e inteligência que são seguros o suficiente para trabalhar junto com seres humanos (GIBBS, 2016).

\section{A Inteligência Artificial trará grandes oportunidades e criará mais empregos do que eliminará}

Segundo a empresa de consultoria Gartner (2017a), a Inteligência Artificial criará 2,3 milhões de empregos até 2020, enquanto eliminará 1,8 milhão. Muitas inovações significativas no passado foram caracterizadas por um período de transição, que gerava perdas de empregos por certo tempo, ao qual se seguia uma fase de recuperação e de transformação nos negócios e mais prosperidade. A IA pode melhorar a produtividade de muitas organiza- 
ções, eliminando milhões de posições de médio e baixo nível, mas também criando milhões de posições de nível médio e alto nível (GARTNER, 2017a). O gráfico 2 indica a evolução dos postos de empregos que serão gerados pela aplicação das tecnologias de Inteligência Artificial.

Gráfico 2: Impacto das tecnologias de Inteligência Artificial nos empregos do mundo até 2025 (em milhões).

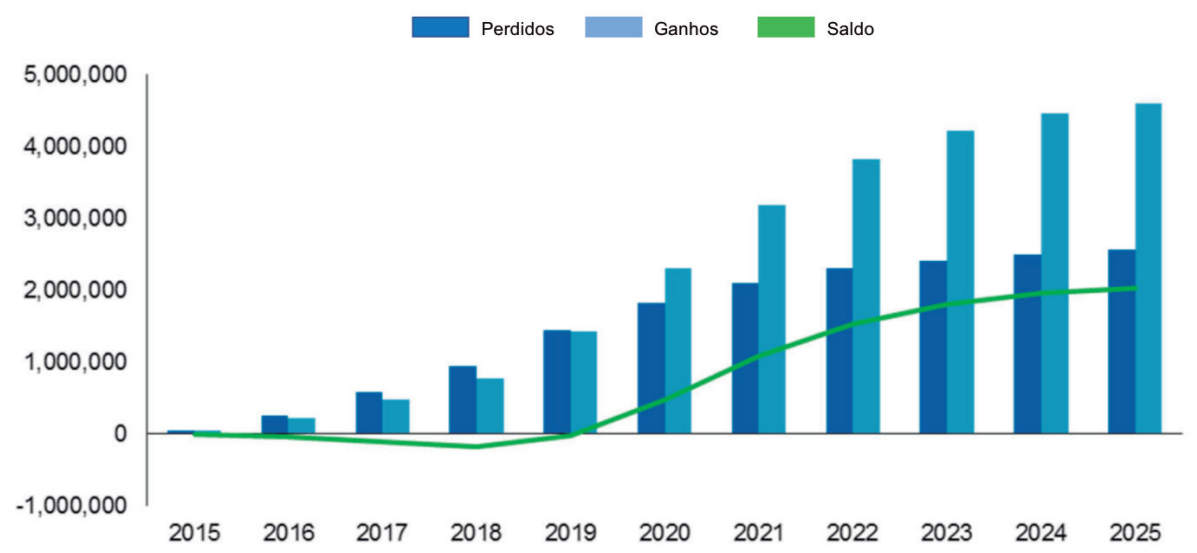

Fonte: Gartner, 2017b. Adaptado pelos autores.

Pode-se esperar que a utilização da IA continuará crescendo de forma constante a partir de 2020. Em 2021, o aumento de IA gerará US\$ 2,9 trilhões em valor comercial e recuperará US $\$ 6,2$ bilhões de horas de produtividade do trabalhador. A longo prazo, a IA reduzirá o custo da mão de obra como uma porcentagem da receita, mas uma parte dessa receita continuará se traduzindo em novos empregos, embora empregos diferentes, de maior qualificação, com remuneração superior àqueles que foram tornados obsoletos (TRUDELL; HAGIWARA; JIE, 2014). As indústrias experimentarão diferentes níveis de economia de tempo e esforço. Apenas algumas indústrias sofrerão perda geral de emprego, outras terão perda de emprego por pouco anos. A maioria das indústrias sequer experimentará perda líquida de emprego. Atualmente, um grande número de empresas iniciou projetos e iniciativas de IA e os investimentos de capital estão levando a proliferação de startups de IA. A inteligência artificial já demonstrou resultados comprovados em diversas aplicações, como detecção de anomalias, cibersegurança, negociação de valores mobiliários, diagnósticos médicos, satisfação do cliente, classificação de sequências de DNA e muitos outros casos. Apesar da imensa 
possibilidade de ganhos com o uso da IA, ainda persistem temores com sua utilização, em parte por se confundir seus efeitos sobre os empregos com aqueles gerados pela automação (TRUDELL; HAGIWARA; JIE, 2014).

\section{O trabalho sem futuro}

Há mentes inteligentes em todos os lados desta questão. Alguns, como o professor Stephen Hawking, acreditam que o aumento de IA representa uma ameaça existencial. Ele disse a uma audiência de rádio da BBC: "Eu acho que o desenvolvimento de inteligência artificial completa poderia significar o fim da raça humana (MCDERMOTT, 2018).

Stephen Hawking, Elon Musk, Bill Gates e outros pesquisadores, cientistas e especialistas em inteligência artificial estão alertando sobre os perigos potenciais da inteligência artificial, a qual pode avançar além do controle humano à medida que se torna capaz de reescrever autonomamente seu próprio código de programação com base em interação, implementá-lo em escala, modificar seus objetivos a partir de análises de contextos e superar o intelecto humano em termos de capacidade de processamento (BBC, 2014). A ideia de que, em algum momento futuro, a inteligência artificial superaria a humana recebeu o termo de "singularidade tecnológica", a partir do texto do cientista e escritor Vernor Vinge (VINGE, 1993). A despeito dos temores a respeito destas possibilidades, o que já é certo é que a Inteligência Artificial e outras tecnologias, como biologia sintética, ciência computacional, nanotecnologia, computação quântica, impressão 3D, Internet das Coisas, veículos autônomos e robótica terão impactos fundamentais sobre a natureza do trabalho, da economia e da cultura até 2050. Se os sistemas socioeconômicos não se adequarem para um cenário de aceleração tecnológica, integração e globalização digitalizada, então metade do mundo pode estar desempregado em 2050 (GLENN; FLORESCU, 2015).

Um dos pontos que vale a pena destacar nesta discussão sobre inteligência artificial é a urgência de uma gigantesca e profunda reestruturação mundial envolvendo diversos sistemas, mecanismos, políticas, investimentos, processos de produção e distribuição, sistemas educacionais, entre tantos outros, para suportar as transformações que estas novas tecnologias já estão provocando e que, em poucos anos, atingirão novos patamares de complexidade e potência - o que é consenso entre otimistas e pessimistas. Tal re- 
estruturação depende, ainda, de um excepcional esforço colaborativo e de enorme capacidade de articulação política para envolver inúmeros atores, em muitos casos, com interesses distintos e contraditórios. Soma-se a isto o desafio de gerenciar uma iniciativa que, em termos de complexidade, se assemelha a uma gigantesca operação de guerra, como o plano de retomada da Europa na Segunda Guerra Mundial, que culminou com o desembarque das tropas aliadas nas praias da Normandia, na França, em 6 de junho de 1944, após mais de um ano de planejamento e preparação. Em outras palavras, todos os ganhos em termos de preservação dos empregos e até mesmo seu crescimento, como destacado em algumas previsões (VOGLER-LUDWIG; DÜLL; KRIECHEL, 2016; GARTNER, 2017a; BMAS, 2017), são supostamente viáveis desde que todas as premissas sejam atendidas e que diversas restrições sejam superadas. Mesmo países estruturalmente bem preparados e organizados para o enfrentamento desta transformação, como a Alemanha, dependem de uma combinação de fatores complexos para obter sucesso. Com sua população economicamente ativa diminuindo por conta da curva demográfica, a Alemanha apoia sua estratégia em dois pilares: a integração dos imigrantes como força de trabalho e o aumento da produtividade necessário para compensar o risco de contração econômica. O primeiro pilar traz o desafio da inserção social associado a um bem-sucedido programa de educação e qualificação desta mão de obra. O segundo depende do sucesso na implantação acelerada da Indústria 4.0 - para o qual o país já está se movimentando de forma surpreendente. A Alemanha estabeleceu uma dupla estratégia em relação a Indústria 4.0: obter os ganhos de eficiência e produtividade na sua própria indústria de forma que possa produzir com menos recursos humanos e, ainda, se tornar uma fornecedora mundial de equipamentos, sistemas e soluções de manufatura avançada para outros países que buscarão adequar seus próprios parques e configurá-los para o ambiente de digitalização. Para sua estratégia lograr sucesso, além dos próprios desafios e condicionantes internos, precisa, por um lado, se impor como fornecedora competitiva enfrentando a competição de outros países. Por outro, depende do ambiente econômico externo. A OECD - Organização para a Cooperação e Desenvolvimento Econômico - aponta perspectivas frustrantes para a economia mundial até 2060, com uma taxa de crescimento do PIB para os países que compõem a OCDE e o G-20 estimada em 2,7\% ao ano. No período compreendido entre 1996 e 2010, o crescimento anual do PIB foi de 3,4\% (OECD, 2012). 
Esta análise dos desafios da Alemanha, dentro de uma bem elaborada estratégia de digitalização, serve para ilustrar quão desiguais e incertos serão os impactos da digitalização avançada entre os países. Também sugere uma visão mais cautelosa sobre os impactos que as novas tecnologias combinadas em inovações disruptivas podem trazer para o trabalho, o emprego e a sociedade como um todo. Enfim, há consenso sobre os efeitos deletérios, mas não há sobre a possibilidade concreta de se obter os benefícios possíveis e sobre a intensidade prevista em algumas projeções. Também já é evidente que, mesmo num cenário positivo, haverá perdedores. Tanto em termos de nações, cidades, empresas e indivíduos. Não existe, neste caso, um "ganho médio". A afirmação meramente quantitativa de que, por exemplo, a criação de um milhão de novas vagas compensará a extinção de 750 mil não é verdadeira do ponto de vista micro, do ponto de vista do indivíduo ou de grupos de indivíduos. O trabalhador de baixa qualificação dispensado por sua função ter se tornado redundante com a tecnologia não conseguirá ocupar uma das novas vagas que exigem um mais alto padrão de formação. Neste caso, também há consenso de que a maior parte dos atingidos pelos efeitos da automação e digitalização serão as pessoas que exercem as funções que não exigem qualificação sofisticada e que recebem baixa remuneração em termos de salário. A consultoria McKinsey estima que as necessidades de transição de carreira serão enormes, considerando onde ela é viável, e envolverão pelo menos 375 milhões de trabalhadores que precisarão desenvolver novas habilidades, no caso de sucesso na adoção rápida da digitalização pelos países. Se a transição for lenta, o desemprego aumentará e ainda provocará depreciação dos valores dos salários (MGI, 2017c).

Segundo Osborne e Frey (2013), 47\% dos empregos se enquadram na categoria de alto risco, ou seja, empregos que podem ser automatizados em período relativamente curto, na próxima década ou duas décadas. Destes, pela primeira vez na história, estarão ameaçados os empregos em inúmeras atividades do setor de serviços, incluindo serviços administrativos e o chamado trabalho do conhecimento. 


\section{O desemprego estrutural atinge finalmente o setor de serviços}

Dois aspectos merecem destaque quando se avalia o fenômeno da ameaça de desemprego estrutural no setor de serviços: em primeiro lugar, o setor de serviços é o maior responsável pela geração de riqueza na maioria dos países de economia desenvolvida e países emergentes, respondendo pela parcela principal do seu PIB. Na Alemanha, o setor de serviços responde por cerca de $70 \%$ do PIB e no Brasil por cerca de 75\%. Também é responsável pela maior parte dos empregos. Na Alemanha compreende $72 \%$ dos empregos e nos Estados Unidos 80,1\% (BLS, 2017; IBGE, 2018; DW, 2018).

A adoção da automação de processos, tecnologias de reconhecimento de documentos eletrônicos e inteligência artificial abrem inúmeras possibilidades de otimização (VOGLER-LUDWIG; DÜLL; KRIECHEL, 2016). Diversas ocupações do setor de serviços serão impactadas, afetando a maioria dos trabalhadores em atividades de transporte e logística, trabalhadores de escritórios e de apoio administrativo, como analistas. Também os trabalhadores administrativos das fábricas serão afetados (OSBORNE; FREY, 2013). A digitalização do setor de serviços atingirá de forma importante o serviço público. As previsões de redução já estão consolidadas em alguns países, como Alemanha e Estados Unidos, onde se espera redução de 15\% das ocupações somente nos serviços públicos federais até 2024 (BLS, 2017).

\section{Automatizando as funções do trabalhador do conhecimento}

A nova fronteira para a diferenciação competitiva nas empresas não é mais a automação de transações e manutenção de registros, trata-se agora de permitir experiências de transações com clientes e fornecedores, bem como entre as mais diversas funções dentro da própria organização. Envolve gerenciar processos, interfaces e vínculos entre diferentes sistemas, lidar com exceções a transações, conformidade, prevenção e mitigação de riscos, reação a fraudes, definição de contingências e tratativas de emergências. Em suma, a vantagem estratégica vem da integração de informações e aplicativos para automatizar as funções do trabalhador do conhecimento (DAVIS, 2006). 
O desafio da automatização do trabalho do conhecimento e da potencialização deste trabalho envolve mais do que tornar os sistemas e as informações interoperáveis. Trata-se de computação com conhecimento, que envolve o domínio sobre a teoria e as informações necessárias para realizar uma tarefa. Os sistemas de informação se concentravam em trazer informações para o trabalho, isto é, a consciência da situação. O conhecimento necessário para fazer um trabalho é algo que depende do humano, que um funcionário deve trazer consigo através de educação e experiência prévias ou adquirir através da aprendizagem (no próprio trabalho ou por treinamento formal). Esta educação é dispendiosa para ser adquirida e provisionada, assim como o é o processo de aprendizagem, que, normalmente, ainda demanda tempos significativos para se concretizar. Existe, ainda, o risco da perda do conhecimento, que em parte se vai com as pessoas que se desligam da organização, gerando determinado retrocesso que tornará necessária nova fase de experimentação e assimilação, com a inevitável repetição de falhas. A automação do trabalho de conhecimento está sendo feita a partir de uma nova abordagem, visto que não basta que se ofereça apenas a informação, mas também toda a teoria e os modos de raciocínio necessários para realização de um trabalho ou uma tarefa (DAVIS, 2006). As soluções que estão surgindo lidam com bases de conhecimento de grande escala, formas complexas de avaliação da situação, modos sofisticados de raciocínio baseados em valores e comportamentos de sistemas autônomos. Chamadas de tecnologias semânticas, lidam com os desafios da infraestrutura centrada na rede, automação do trabalho do conhecimento e sistemas de construção que sabem o que estão fazendo, pois aprendem e se fundamentam como os humanos. As tecnologias semânticas são capacidades funcionais que permitem aos computadores criar, descobrir, representar, organizar, processar, gerir, fundamentar, apresentar, compartilhar e utilizar significados e conhecimentos para atingir fins comerciais, pessoais e sociais (BUXMANN; HESS; RUGGABER, 2009; THESEUS, 2018).

Serviços de assessoria jurídica e serviços financeiros já estão começando a ver os benefícios da automação do trabalhador do conhecimento. Os escritórios de advocacia, por exemplo, estão usando computadores que podem examinar milhares de esclarecimentos e precedentes legais para auxiliar no trabalho de pesquisa preliminar que pode envolver centenas ou milhares de horas de trabalho. O sistema Clearwell da Symantec usa análise de lingua- 
gem para identificar conceitos gerais em documentos e apresentar os resultados graficamente. Em um caso, esse software conseguiu analisar e classificar mais de 570.000 documentos em dois dias. Nos serviços financeiros, a inteligência artificial tem desempenhado um papel importante nas análises e nos processos de transações financeiras há algum tempo. Os bancos estão utilizando a aprendizagem de máquina para detectar fraudes e identificar situações como cobranças ou reclamações fora do comportamento normal de compra de uma pessoa. Mesmo serviços como o Future Advisor usam a inteligência artificial para oferecer conselhos financeiros personalizados de forma econômica e em escala. Estima-se que, até 2025, ganhos de produtividade de 45 a 55\% possam ser alcançados sobre o trabalho de uma massa de 25 milhões de trabalhadores do conhecimento deste setor, o que levaria ao impacto econômico de US\$ 600 a US\$ 800 bilhões por ano (MGI, 2013).

\section{Inteligência Artificial e a Morte do setor de TI da Índia}

Ao longo dos últimos 25 anos, a Índia emergiu como um importante destino para a tecnologia da informação - a contrapartida de serviços de baixo custo para o que a China faz em termos de fabricação de baixo custo. Mas o nicho de serviços de TI de baixo custo que a Índia ocupa é altamente vulnerável à automação pela inteligência artificial. Novas capacidades, como o código de autorreparação, reduzem a necessidade de implantação em grande escala de profissionais de TI baratos. Sistemas habilitados para voz e a personalização cada vez maior deverão diminuir, se não eliminar, a demanda para os centros de chamadas, pelos quais a Índia tornou-se famosa. Cerca de 69\% dos empregos na Índia estão em risco de deslocamento devido à inteligência artificial e automação (SINGH, 2017). Nas cinco principais empresas de serviços de TI da Índia, há queda no crescimento do emprego de até 40\%. Em particular, a Wipro lançou uma plataforma de inteligência artificial conhecida como Holmes que usa ferramentas que realizam tarefas repetitivas e demitiu 12 mil funcionários. A Índia enfrenta enormes desafios colocados pela revolução tecnológica em curso. Se nada for feito, cerca de 69\% dos trabalhos estarão perdidos para automação e a Índia testemunhará uma crise como nunca viu antes (SINGH, 2017). 


\section{Tecnologia atinge setor de saúde e assistência social}

O setor de cuidados com saúde e assistência social é uma das promessas de expansão para o emprego. Nos EUA, sua participação foi de 12\% em 2014 e as projeções indicam um aumento da participação para 13,6\% da força total de trabalho em 2024. Espera-se que sejam adicionados mais de 4 milhões de novos postos de trabalho (BLS, 2017). Entretanto, mesmo este setor em grande expansão por conta da curva demográfica também apresenta oportunidades de racionalização. Robôs começam a ser usados para limpeza, testes laboratoriais, atendimentos e outros serviços. Os efeitos negativos sobre o emprego surgem também para profissionais de saúde médica, em especial profissões de laboratório e enfermagem (VOGLER-LUDWIG; DÜLL; KRIECHEL, 2016). A automação do trabalho de conhecimento pode ter efeitos importantes nos serviços de cuidados de saúde. Os oncologistas no Memorial Sloan-Kettering Cancer Center em Nova York estão usando o supercomputador Watson da IBM para fornecer diagnósticos de tratamento crônico e tratamento do câncer, acessando o conhecimento de 600 mil relatórios de evidências médicas, dois milhões de páginas de texto de literatura científica de 42 revistas médicas e 1,5 milhão registros de pacientes e ensaios clínicos no campo da oncologia, além dos dados clínicos e genéticos do paciente. Com isto, o Watson compara os sintomas individuais de cada paciente, sinais vitais, histórico familiar, medicamentos utilizados, estrutura genética, dieta e rotina de exercícios para diagnosticar e recomendar um tratamento com maior probabilidade de sucesso (IBM, 2017). Já a empresa Wellpoint adotou a tecnologia do Watson para oferecer suporte a decisões e acelerar o processo de aprovação de requisições médicas, que antes levavam dias e agora são concluídas em alguns segundos. Isso só foi possível porque o sistema foi treinado com 25 mil casos históricos, aos quais são aplicadas técnicas de geração de hipóteses e aprendizado baseado em evidências para gerar recomendações que auxiliam na tomada de decisão. A computação cognitiva na saúde também pode auxiliar na redução de custos e no aumento da eficiência das organizações, por meio do cruzamento de dados que permitem uma gestão mais eficiente (IBM, 2017). 


\section{Varejo: um gigantesco gerador de empregos}

Um setor também bastante relevante e intensivo em mão de obra é o varejo. O setor de varejo é o $4^{\circ}$ maior gerador de empregos nos EUA, sendo responsável por cerca de 15,820 milhões empregos em 2016. A tabela 1 indica a participação dos quatro maiores setores geradores de emprego nos EUA (BLS, 2017).

Tabela 1: Participação dos maiores setores no total dos empregos nos EUA em 2016

\begin{tabular}{c|c}
\hline Setor & Participação no total de empregos \\
\hline Serviços profissionais e de negócios & $12,9 \%$ \\
Governos estaduais e locais & $12,4 \%$ \\
Cuidados com saúde e assistência social & $12,2 \%$ \\
Varejo & $10,1 \%$ \\
\hline
\end{tabular}

Fonte: BLS (2017). Elaborado pelo autor.

O varejo multicanal tem uma estrutura de custos complexa baseada em dois principais fatores: custo dos bens vendidos e custo da mão de obra. Os desafios competitivos e os investimentos necessários para melhorar a experiência dos clientes implicarão na automatização de tarefas e processos, que permaneceram inalterados por décadas. Com a aplicação de tecnologias como IA e robótica, os varejistas querem usar a automação de processos inteligentes para identificar, otimizar e automatizar atividades intensivas e repetitivas. Muitos varejistas já estão aplicando o processo de check-out automático em suas lojas (GARTNER, 2017a). O Walmart, maior empresa mundial de varejo, está atualmente testando um processo de digitalização e varredura habilitado pelo dispositivo móvel do cliente. Alguns varejistas estão experimentando soluções robotizadas com assistentes virtuais para atendimento ao cliente. A iniciativa do Walmart na adoção da digitalização em suas operações de varejo tem um significado importante. O Walmart é a empresa com a maior receita mundial (485,873 bilhões de dólares) e maior empregadora com 2,3 milhões de funcionários (FORTUNE, 2017). A gigantesca empresa fundada em 1962 nos EUA é a precursora histórica da implantação do conceito quick response em 1986, através de um projeto feito em parceria com a empresa Procter \& Gamble. Este projeto aplicava conceitos derivados do sistema Just in time da Toyota ao varejo, propondo a utilização de tecnologia de sistemas para viabilizar a troca em tempo real de informações de venda, 
produção e entrega entre participantes da cadeia de fornecimentos, com o objetivo de otimizar a gestão de estoques, produção e entrega e, assim, reduzir os custos envolvidos através da redução da incerteza de fornecimento - que estimula a formação de estoques de segurança - e da sincronização da cadeia de fornecimento. Os conceitos utilizados neste projeto foram consolidados e difundidos no setor de varejo a partir criação em 1992 do movimento ECR - Efficient Consumer Response, que lançou as bases do sistema supply chain management, ou gerenciamento da cadeia de suprimentos, adotado por outras indústrias (WOOD, 1993; CHOPRA; MEINDL, 2015).

Em outras palavras, o Walmart, por sua importância no varejo mundial, seja pela influência que exerce sobre uma enormidade de empresas relevantes que são suas fornecedoras ou sobre seus concorrentes, propiciará, sem dúvida, a disseminação em escala da digitalização pelo varejo mundial e também pela indústria de alimentos, vestuário, produtos de limpeza e higiene e outras que participam da cadeia de fornecimento do varejo. Outra questão relevante sobre seu envolvimento no uso das novas tecnologias de digitalização é que o Walmart possui forte direcionamento para a eficiência, sendo referência mundial na adoção de princípios, na aplicação de técnicas e na adoção da tecnologia como instrumento para ganhos constantes de eficiência operacional. Isto sugere que a propagação da digitalização sobre os processos e operações do varejo será intensa, assim como a busca por ganhos de eficiência.

O setor de varejo nos EUA já vem apresentando redução de seus postos de trabalho da ordem de 3\%, como resultado da digitalização (VOGLER-LUDWIG; DÜLL; KRIECHEL, 2016). Os cortes no setor são relativamente pequenos frente à economia do país como um todo. Entretanto, para os americanos buscando uma porta de entrada no mercado de trabalho, é um obstáculo. Contratos em lojas de comércio representam um terço dos primeiros trabalhos de jovens nos Estados Unidos. Em 2020 a tecnologia trará impactos maiores. Estima-se que os dez principais varejistas apliquem algoritmos avançados que permitirão corte de até um terço das equipes de merchandising. Pelo menos um grande varejista multicanal pilotará uma loja física totalmente automatizada e sem suporte humano. Aplicativos de conversação e atendimento digital processarão 50\% dos pedidos de atendimento ao cliente (GARTNER, 2017b).

O segundo, mas não menos importante, aspecto que merece destaque quando se avalia o fenômeno da ameaça de desemprego estrutural no setor de serviços é que este setor, historicamente, absorveu parte da mão de obra 
que foi sendo eliminada do setor agrícola e industrial por conta dos seus próprios processos de automação e aumento de eficiência. Por abarcar variadas atividades que exigem baixa qualificação, o setor de serviços gerou oportunidades de trabalho e renda para egressos da indústria e do campo (OSBORNE; FREY, 2013). Estes setores vêm apresentando curvas típicas e decrescentes de absorção de mão de obra. O gráfico 3 mostra a redução da participação do emprego na indústria no Reino Unido.

Gráfico:3 Taxa de emprego na manufatura no Reino Unido.

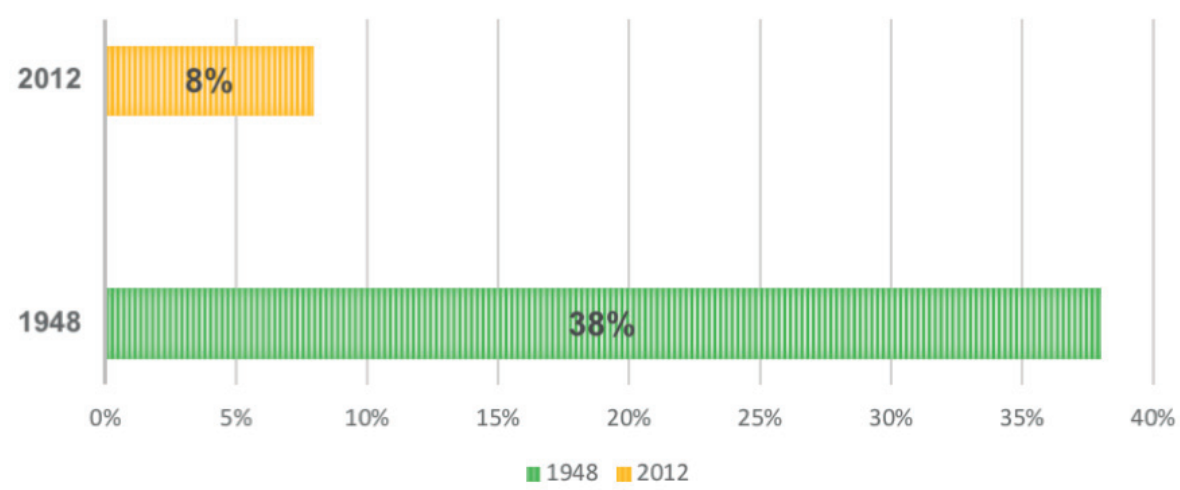

Fonte: Deloitte (2015). Adaptado pelos autores.

Em termos de migração da mão de obra, não haverá mais a possibilidade de um setor absorver grandes quantidades de trabalhadores de outros, visto que agora todos seguem a lógica da automação com ganhos de produtividade sendo obtidos através da substituição do trabalho humano.

\section{A demanda por trabalhadores qualificados}

Parte da visão otimista com a construção de um futuro brilhante sustentado pela digitalização da economia se baseia na expectativa de criação de novos postos de trabalho mais qualificados e melhor remunerados (TRUDELL; HAGIWARA; JIE, 2014). Entretanto, a oferta de mão de obra no cenário básico pode não ser suficiente para cobrir os requisitos de qualificação de uma estratégia de digitalização acelerada, mesmo em países desenvolvidos como a Alemanha (VOGLER-LUDWIG; DÜLL; KRIECHEL, 2016). Os sistemas educacionais não acompanharam a mudança da natureza do trabalho, resultando em muitos empregadores dizendo que não conseguem encontrar trabalhado- 
res suficientes com as habilidades de que eles precisam. Em uma pesquisa da consultoria McKinsey com jovens e empregadores em nove países, 40\% dos empregadores afirmaram que a falta de habilidades foi o principal motivo para as vagas de emprego não terem sido preenchidas. 60\% disseram que os novos diplomados não estavam adequadamente preparados para o mundo do trabalho. Houve lacunas em habilidades técnicas, mas também em habilidades básicas, como comunicação e trabalho em equipe (MGI, 2017a).

\section{Considerações Finais}

Os impactos que as novas tecnologias podem gerar sobre a força de trabalho do século XXI têm precedentes e são de uma ordem de grandeza semelhante às mudanças ocorridas em outros momentos da história. Essas mudanças não resultaram em desemprego em massa a longo prazo, porque foram acompanhadas da criação de novos tipos de trabalho (MGI, 2017b). Entretanto, não podemos dizer definitivamente se as coisas acontecerão da mesma forma desta vez. Quando uma empresa desenvolve seu planejamento tendo como base exclusiva os seus resultados históricos e os recentes - por exemplo os resultados do ano fiscal anterior - e manipula estes dados matematicamente para identificar sazonalidades e captar eventuais tendências que, na sequência, são analisadas sob a luz de algumas informações externas - como a situação da economia, taxas de câmbio e situação dos concorrentes -, diz-se que ela está tentando andar para frente olhando pelo retrovisor.

A nova revolução tecnológica traz características determinantes que a diferenciam estruturalmente das revoluções anteriores. A velocidade com a qual a transformação está ocorrendo, o ciclo reduzido de escalabilidade das novas tecnologias, a quantidade de tecnologias disruptivas surgindo ou amadurecendo simultaneamente e a diferente demanda de qualificação para os trabalhadores - que privilegia algumas ocupações à medida que exclui outras - são algumas das diferenças em relação ao passado. Inovações tecnológicas, como a chamada nuvem humana, afetarão dramaticamente a estrutura e o mercado de trabalho. Imaginar as perspectivas do futuro do trabalho sem considerar estas diferenças seria um equívoco. Podem-se considerar como características diferenciadoras da nova revolução tecnológica em termos do impacto sobre o trabalho:

- Novas empresas que não geram empregos;

- Novas tecnologias que favorecem a substituição do trabalho humano; 
- A compactação das cadeias produtivas;

- Corporações ainda maiores com menor número de concorrentes;

- Velocidade acelerada da transformação;

- Impacto nos três setores da economia;

- Novas oportunidades que não são inclusivas.

O quadro 3 apresenta as características diferenciadoras da nova revolução tecnológica.

Em curso, portanto, uma profunda transformação não apenas nos mundos do trabalho, mas em todas as dimensões da vida social e da vida de todas as pessoas. Sem dúvida, as novas condições de trabalho que se impõem inexoravelmente a todos os países do mundo numa economia globalizada exigirão a elaboração de novas políticas públicas que permitam responder rápida e adequadamente aos novos desafios, sobretudo o de preparar as novas gerações dos países emergentes e em desenvolvimento para o enfrentamento do processo contínuo e veloz de mudanças, o que requer especial atenção ao processo educacional de crianças e jovens. E isso porque, se o século XX foi o século do forte assalariamento da classe proletária graças aos milhões de empregos gerados pelo taylorismo e fordismo, empregos de baixa qualidade, é verdade, mas empregos com alguma proteção do Estado devido às políticas de intervenção na economia, o século XXI será o século do "fim dos empregos”, como já afirmava Jeremy Rifkin (2004) no seu livro polêmico O Fim dos Empregos - O Declínio Inevitável dos Níveis dos Empregos e a Redução da Força Global de Trabalho, ou, para sermos mais otimistas, o século da redução significativa dos empregos e do surgimento de novas e precárias relações de trabalho.

As novas condições de trabalho exigirão a aquisição das competências profissionais demandadas e definidas pelas novas tecnologias que redefinem o perfil do trabalhador ao redefinirem o conteúdo intelectual e cultural de todas as atividades econômicas e de trabalho, ao mesmo tempo em que exigirão uma clara e sempre atualizada regulamentação das relações de trabalho a fim de garantir contínuos investimentos do capital e, em consequência, a geração de empregos e/ou novas oportunidades de trabalho protegido. Muito embora já estivessem delineadas com clareza nas últimas décadas do século passado, essas são as questões que o século XXI define como as mais urgentes para aqueles países que, como o nosso, não se prepararam para enfrentá-las. 
Quadro 3: Características diferenciadoras da nova revolução tecnológica.

Características diferenciadoras da nova revolução tecnológica

\section{Novas empresas que não geram empregos}

Novas empresas são intensivas em tecnologia e não em mão de obra. Nascem com o signo da digitalização e automação e geram menos postos de trabalho em comparação com as empresas do século XX. Produzem sob demanda, sem necessidade de estoques e de grandes equipes. Contratam boa parte do trabalho necessário na forma de prestação de serviços ou projetos, através da nuvem humana ${ }^{1}$.

\section{Novas tecnologias que favorecem a substituição}

Algumas das principais tecnologias envolvidas favorecem a substituição de pessoas: automação, robotização, inteligência artificial, realidade virtual e aumentada, aprendizagem de máquina, reconhecimento de voz e controles ciber físicos. Há grande diferença para os efeitos da internet, cujas possibilidades proporcionaram maior criação do que eliminação de empregos.

\section{Compactação das cadeias produtivas}

Inovações anteriores, principalmente em termos de produtos e bens, propiciaram a criação das cadeias produtivas ou de fornecimento. A cadeia de fornecimento de óculos, por exemplo, envolve inúmeras empresas em diversas etapas desde a produção da matéria-prima passando pela fabricação do produto, distribuição, transporte e venda, gerando inúmeros empregos. Com a manufatura aditiva (impressão 3D) será possível aos consumidores imprimir em sua própria casa a armação dos óculos de sua preferência. Neste caso, quase toda a cadeia produtiva é eliminada.

\section{Corporações ainda maiores com menor número de concorrentes}

Grandes corporações incorporam rapidamente as novas tecnologias e inovações e reduzem extraordinariamente seus custos (inclusive com pessoas). Expansão dos níveis de produtividade e lucratividade. Empresas menores tem dificuldade de competir e são absorvidas ou extintas. Os processos de fusão e aquisição reduzem o número de empregos de cada setor.

\section{Velocidade acelerada da transformação}

O tempo gasto para uma nova tecnologia ser adotada em larga escala diminui rapidamente. Enorme quantidade de tecnologias disruptivas surge de forma quase simultânea. Enorme convergência e combinação entre as novas tecnologias. Empresas e governos não conseguem acompanhar o ritmo das inovações. Pessoas não conseguem se adaptar e se qualificar rapidamente para as mudanças no mercado de trabalho.

\section{Impacto nos três setores da economia}

Agricultura 4.0 aumenta ganhos de produtividade no campo e atinge principalmente países ainda com grandes contingentes de trabalhadores no campo. Indústria 4.0 amplia robotização e automação nas fábricas. As smart factories trabalham de forma quase autônoma, com pouquíssimos funcionários. As cadeias de suprimentos são otimizadas e a desintermediação reduz postos de trabalho. A inteligência artificial, big data e tecnologias associadas automatizam processos administrativos, atendimentos, análises, diagnósticos, processos de ensino e outras atividades do setor de serviços. Diminui a possibilidade de grandes quantidades de trabalhadores dispensados migrarem para outros setores da economia.

\section{Novas oportunidades não são inclusivas}

As novas oportunidades de trabalho demandarão maior qualificação. Boa parte dos trabalhadores com menor qualificação dos setores de produção, logística, varejo e escritórios não será beneficiada com a digitalização da economia. Redução das vagas de média qualificação criará uma polarização entre trabalhadores de altos e de baixos salários. Os empregos se concentrarão nas capitais e em poucas cidades que detenham profissionais mais qualificados. Alguns dos países mais ricos serão beneficiados, enquanto outros enfrentarão dificuldades. Países de economia em desenvolvimento sofrerão desindustrialização. As economias mais pobres não conseguirão evoluir para o estágio industrial.

Fonte: Elaborado pelos autores. 


\section{Referências bibliográficas}

ABB. Yumi. (2018), Creating an Automated Future Togheter. Online. Disponível em: <http://new.abb.com/products/robotics/industrial-robots/yumi>. Acesso em: 14 jan. 2018.

ANTUNES, R. (2006), A era da informatização e a época da informalização: riqueza e miséria do trabalho no Brasil. In: . Riqueza e miséria do trabalho no Brasil. São Paulo: Boitemp. pp. 15-25.

BBC. (2014), Stephen Hawking warns artificial intelligence could end mankind. Produção: BBC News, London. Vídeo, 5’05”. Publicado em 2 dec. 2014. Disponível em: <http://www.bbc.com/news/technology-30290540>. Acesso em: 12 jan. 2018.

BLS - Bureau of Labor Statistics. (2017), Employment Projections - 2014-24. Bureau of Labor Statistics U.S. Department of Labor. Online. Disponível em: <http://www.bls.gov/news.release/archives/ecopro_12082015.pdf>. Acesso em: 10 jan. 2018.

BMAS. (2017), Weis Buch - Arbeiten 4.0. Berlin: Bundesministerium für Arbeit und Soziales Abteilung Grundsatzfragen des Sozialstaats, der Arbeitswelt und der Sozialen Marktwirtschaft. Online. Disponível em: < https://www.bmas.de/SharedDocs/Downloads/de/pdf-publikationen/a883-weissbuch.pdf? blob=publicationFile $>$. Acesso em: 22 jan. 2018.

BRYNJOLFSSON, Erick; MCAFEE, Andrew. (2011), Race Against the Machine: How the Digital Revolution is Accelerating Innovation, Driving Productivity, and Irreversibly Transforming Employment and the Economy. Lexington, Massachusetts: Digital Frontier Press.

BUXMANN, Peter; HESS, Thomas; RUGGABER, Rainer. (2009), Internet of Services. Business \& Information Systems Engineering - Bise Journal, v. 1, n. 341, online. Disponível em: < http://link-springer-com.ez95.periodicos. capes.gov.br/content/pdf/10.1007\%2Fs12599-009-0066-z.pdf $>$. Acesso em: 16 jan. 2018.

CAMPOS, V. F. (1990), Gerência de qualidade total: estratégia para aumentar a competitividade da empresa brasileira. Belo Horizonte: Fundação Christiano Ottoni - Escola de Engenharia da UFMG - Bloch Editores.

CASTELLS, Manuel. (2006), A Era da Informação: Economia, Sociedade e Cultura. vol. 1, A Sociedade em Rede. 9 ed. São Paulo: Paz e Terra.

CHOPRA, Sunil; MEINDL, Peter. (2016), Gestão da Cadeia de Suprimentos: estratégia, planejamento e operações. 6 ed. São Paulo: Pearson.

CORRÊA, H.; CORRÊA, C. (2017), Administração de produção e operações: manufatura e serviços: uma abordagem estratégica. 4 ed. São Paulo: Atlas. 
DAVIS, Mills. (2006), Semantic Wave 2006: Executive Guide to the Business Value of Semantic Technologies. Washington: Semantic Interoperability Community of Practice (SICOP). Online. Disponível em: http://semanticommunity.info/Other/Federal_Semantic_Interoperability_Community_of_Practice. Acesso em: 3 jan.2018.

DELOITTE. (2015), Industry 4.0: Challenges and solutions for the digital transformation and use of exponential technologies. [S.I.]: Deloitte. Online. Disponível em: < https://www2.deloitte.com/content/dam/Deloitte/ch/Documents/manufacturing/ch-en-manufacturing-industry-4-0-24102014.pdf > . Acesso em: 5 dez. 2017.

DW DEUTSCH WELLE. (2018), O setor de serviços. Online. Disponível em: <http://www.dw.com/pt-br/0-setor-de-serviços/a-1017270>. Acesso em: 20 jan. 2018.

EUROPEAN COMMISSION. (2012), Communication from the commission to the European Parliament, the council, the European Economic and Social Committee and the Committee of the regions: A European strategy for key enabling technologies - a bridge to growth and jobs. Bruxelles: European Commission. Online. Disponível em: < http://eur-lex.europa.eu/ legal-content/EN/TXT/?uri=CELEX:52012DC0341>. Acesso em: 18 jan. 2018.

FORTUNE. (2017), FORTUNE 500. Online. Disponível em: < http://fortune. com/fortune500>. Acesso em: 15 jan. 2018.

FUKUYAMA, Francis. (2002), Our Posthuman Future: Consequences of the Biotechnology Revolution. 1 ed. New York: Picador.

GARTNER. (2017a), Gartner says by 2020. Artificial intelligence will create more jobs than it eliminates. Stamford: Gartner, 13 dez. 2017. Online. Disponível em: <http://www.gartner.com/newsroom/id/3837763>. Acesso em: 20 jan. 2018.

GARTNER. (2017b), Predicts 2018: AI and the future of work. [Relatório]. Stamford: Gartner. Online. Disponível em: < http://www.commerce-associe. fr/wp-content/uploads/predicts_2018_ai_and_the_fut_342326.pdf >. Acesso em: 21 jan. 2018.

GIBBS, Samuel. (2016), Mercedes-Benz swaps robots for people on its assembly lines. London: The Guardian, 26 fev. 2016. Disponível em: <https:// www.theguardian.com/technology/2016/feb/26/mercedes-nenz-robots-people-assembly-lines >. Acesso em: 15 jan. 2018.

GLENN, Jerome; FLORESCU, Elisabeth. (2015), O Estado do Futuro - Sumário Executivo [Relatório]. Washington: The Millennium Project. Disponível em: <http://107.22.164.43/millennium/2015-SOF-ExecutiveSummary-Portuguese.pdf $>$. Acesso em: 26 jan. 2018. 
HELPAGE. (2015), Global age watch index. London: Helpage International. Online. Disponível em: <htpp://www.helpage.org/global-agewatch/population-ageing-data/global-rankings-table/> . Acesso em: 18 jan. 2018.

HOLDREN, J.; LANDER, E. (2014), Report to the President Accelerating U.S. Advanced Manufacturing [Relatório]. Washington: Executive Office of the President President's Council of Advisors on Science and Technology. Disponível em: <https://www.manufacturingusa.com/sites/prod/files/amp20_ report_final.pdf $>$. Acesso em: 7 dez. 2017.

IBGE - Instituto Brasileiro de Geografia e Estatística. (2018), Pesquisa Anual de Serviços - PAS. Online. Disponível em: <http://www.ibge.gov.br/estatisticas-novoportal/economicas/serviços/9028-pesquisa-anual-de-servicos. html?\&t=destaques $>$. Acesso em: 18 jan. 2018.

IBM. (2017), Conheça o Watson e sua aplicação na saúde. New York: IBM. Disponível em: <https://www.ibm.com/blogs/robertoa/2017/03/conheca-o-watson-e-seu-uso-na-saude/> . Acesso em: 20 nov. 2017.

IMF - International Monetary Fund. (2017), GDP. Online. Disponível em: <http://www.principalglobalindicators.org/regular.aspx?key=60942007>. Acesso em: 18 jan. 2018.

KAGERMANN, H., WAHLSTER, W., HELBRIG, J. (2013), Recommendations for implementing the strategic initiative INDUSTRIE 4.0. Final report of the Industrie 4.0 Working Group [Relatório]. Frankfurt: National Academy of Science Engineering.

MASI, D. D. (org.). (2000), O ócio criativo. Rio de Janeiro: Sextante.

MCDERMOTT, Bill. (2018), Machines can't dream. Davos-Klosters: World Economic Forum. Online. Disponível em: < https://www.weforum.org/agenda/2018/01/machines-can\%27t-dream/ > . Acesso em: 25 jan. 2018.

MGI - McKinsey Global Institute. (2011), Internet matters: the net's sweeping impact on growth, jobs, and prosperity. [Relatório]. San Francisco: McKinsey Global Institute. Online. Disponível em: <http://www.mcksinsey.com/ / media/Mckensey/Industries/High\%20Tech/Our\%20Insights/Internet\%20 matters/MGI_internet_matrters_full_report.ashx>. Acesso em: 20 jan. 2018.

MGI - McKinsey Global Institute. (2013), Disruptive technologies: Advances that will transform life, business, and the global economy. [Relatório]. [S.I.]: McKinsey Global Institute. Online. Disponível em: < https://www.mckinsey. $\mathrm{com} /$ business-functions/digital-mckinsey/our-insights/disruptive-technologies > . Acesso em: 20 jan. 2018.

MGI - McKinsey Global Institute. (2016), Independent work: Choice, necessity and the gig economy. [Relatório]. San Francisco: McKinsey Global Institute. Online. Disponível em: <https://www.mckinsey.com/ /media/McKinsey/Global\%20Themes/Employment\%20and\%20Growth/Independent\%20 
work\%20Choice\%20necessity\%20and\%20the\%20gig\%20economy/Independent-Work-Choice-necessity-and-the-gig-economy-Full-report.ashx $>$. Acesso: 24 jan.2018.

MGI - McKinsey Global Institute. (2017a), Technology, Jobs, and the future of work. San Francisco: McKinsey Global Institute. Online. Disponível em: <http://www.mckinsey.com/ /media/Mckinsey/Global\%20Themes/Employment\%20and\%20Growth/Technology\%20jobs\%20and\%20the\%20future\%20of\%20work/MGI-Future-of-Work-Briefing-note-May-2017.ashx>. Acesso em: 12 nov. 2017.

MGI - McKinsey Global Institute. (2017b), Harnessing automation for a future that works. [Relatório]. San Francisco: McKinsey Global Institute. Online. Disponível em: < http://www.mckinsey.com/global-themes/digital-diruption/harnessing-automation-for-a-future-that-works $>$. Acesso em: 12 nov. 2017.

MGI - McKinsey Global Institute. (2017d), Artificial intelligence: implications for China. In: THE 2017 CHINA DEVELOPMENT FORUM. Online. Disponível em: <http://www.mckinsey.com/-/media/Mckinsey/Global\%20 Themes/China/Artificial\%20intelligence\%20Implications\%for\%20China/ MGI-Artificial-intelligence-implications-for-China.ashx $>$. Acesso em: 5 nov. 2017.

MGI - McKinsey Global Institute. (2017c), Jobs lost, jobs gained: workforce transitions in a time of automation. \{Relatório\}. McKinsey Global Institute. Online. Disponível em: <https:/www.mckinsey.com/ /media/McKinsey/ Global\%20Themes/Future\%20of\%20Organizations/What\%20the\%20future\%20of\%20work\%20will\%20mean\%20for\%20jobs\%20skills\%20and\%20 wages/MGI-Jobs-Lost-Jobs-Gained-Report-December-6-2017.ashx>. Acesso em 24 jan. 2018.

OECD - Organização para a Cooperação e Desenvolvimento Econômico. (2012), Looking to 2060: Long term global growth prospects. Paris: OECD. Online. Disponível em: <http://www.oecd.org/eco/outlook/2060\%20 paper\%Final.pdf>. Acesso em: 27 jan. 2018.

ORWELL, George. (2004), 1984. 29 ed. São Paulo: Companhia Editora Nacional.

OSBORNE, Michael; FREY, Carl Benedikt. (2014), London Agiletown: the relentless march of technology and London's response. London: Deloitte. Online. Disponível em: <https:/www2.deloitte.com/content/dam/Deloitte/uk/Documents/uk-futures/london-futures-agiletown.pdf $>$. Acesso em: 20 jan. 2018.

OSBORNE, Michael; FREY, Carl Benedikt. (2013), The future of employment: how susceptible are jobs in computerization? Oxford: Oxford Martin. Online. Disponível em: <https://www.oxfordmartin.ox.ac.uk/downloads/academic/The_Future_of_Employment.pdf_>. Acesso em: 22 jan. 2018. 
PIKETTY, T. (2015), A economia da desigualdade. Rio de Janeiro: Intrínseca. RANDER, M. (2016), Live Business: The Rise of the Digital Workforce - The digital workforce is replacing the knowledge workforce, and they need Live Business to win. [S.I.]: Digitalist Magazine SAP. Online. Disponível em: $<$ http://www.digitalistmag.com/executive-research/live-business-the-rise-of-the-digital-workforce>. Acesso em: 25 jan. 2018.

RIFKIN, J. (2004), O Fim dos Empregos: O Contínuo Crescimento do Desemprego em todo o Mundo. São Paulo: M. Books Editora.

ROBSBAWM, Eric. (1952), The machine breakers. Oxford: Oxford University Press. Past and Present, n. 1, pp. 57-70. Disponível em: <http://web.csulb. edu/-ssayeghc/theory/wintertheory/machinebreakers.pdf $>$. Acesso em: 25 jan. 2018.

SENGUPTA, Sunita Sinh. (2011), Growth in human motivation: beyond Maslow. Indian Journal of Industrial Relations, v. 47, n. 1, p. 102. Disponível em: <http://ink.galegroup.com/apps/doc/A349721391/AONE?u=capes\&sid $=$ AONE $\&$ xid $=53$ e5cfe $8>$. Acesso em: 10 out. 2017.

SINGH, Harpreet. (2017), Artificial Intelligence and the Death of Indian IT Sector. Boston: Experfy. Online. Disponível em: <http://www.experfy.com/ blog/artificial-intelligence-and-the-death-of-indian-it-sector $>$. Acesso em: 2 nov. 2017.

SLACK, N.; CHAMBERS, S.; JOHNSTON, R. (2009), Administração da Produção. 3 ed. São Paulo: Atlas.

STEWART, I.; COLE, A. (2015), Tecnologia e pessoas: A grande máquina de criação de empregos. [S.I.]: Deloitte. Online. Disponível em: < https://www2. deloitte.com/content/dam/Deloitte/br/Documents/technology/Tecnologia_e_ pessoas.pdf>. Acesso em: 25 jan. 2018.

TAYLOR, Frederick Winslow. (1990), Princípios de Administração Científica. 8 ed. São Paulo: Atlas.

THESEUS. (2018), Das Theseus-Forschungsprogramm: Neue Technologien für das Internet der Dienste. Berlin. Online. Disponível em: < https://www. digitale-technologien.de/DT/Redaktion/DE/Downloads/Publikation/theseus-forschungsprogramm-broschuere.pdf?_blob $=$ publicationFile\&v $=7 \quad>$. Acesso em: 10 jan. 2018.

THINK ACT. (2015), INDUSTRY 4.0 - Manufacturing in Belgium should embrace digital technologies to step up competitiveness and create differentiated products. Brussels: Rol and Berger Strategy Consultant. Online. Disponível em: <https://www.rolandberger.com/en/Publications/pub_industry_4_0_ manufacturing_in_belgium.html>. Acesso em 3 dez. 2017.

TRUDELL, Craig; HAGIWARA, Yuki; JIE, Ma. (2014), Humans Replacing Robots Herald Toyota's Vision of Future. Bloomberg, New York, 7 apr. 2014, online. 
Disponível em: <https://www.bloomberg.com/news/articles/2014-04-06/humans-replacing-robots-herald-toyota-s-vision-of-future $>$. Acesso em: 22 jan. 2018.

VINGE, Vernor. (1993), The coming technological singularity: How to survive in the post-human era. In: Interdisciplinary science and engineering in the era of cyberspace. Ohio: NASA. pp. 11-22. Disponível em: <https://ntrs. nasa.gov/archive/nasa/casi.ntrs.nasa.gov/19940022856.pdf $>$. Acesso em: 9 jan. 2018.

VOGLER-LUDWIG, Kurt; DÜLL, Nicola; KRIECHEL, Ben. (2016), Arbeitsmarkt 2030. Wirtschaft und Arbeitsmarkt in Digitalen Zeitazlter Prognose, 2016. Analyse der Zukünftigen Arbeitskräftenachfrage und Des-angebots in Deutschland auf Basis Eines Rechenmodells. München: Bundesministeriums für Arbeit und Soziales. Online. Disponível em: < http://www.economix. org/assets/content/ERC\%20Arbeitsmarkt\%202030\%20-\%20Prognose\%20 2016\%20-\%20Langfassung.pdf>. Acesso em: 15 dez. 2017.

WORLD ECONOMIC FORUM - WEF. PETERSON, Hayley. (2015), The 12 jobs most at risk of being replaces by robots. New York: World Economic Forum - WEF. Disponível em: <https://www.weforum.org/agenda/2015/11/ the-12-jobs-most-at-risk-of-being-replaced-by-robots/>. Acesso em: 27 jan. 2018.

WEF. (2016), The Future of Jobs: Employment, Skills and Workforce Strategy for the Fourth Industrial Revolution. [Relatório]. Geneva: World Economic Forum. Disponível em: < http://www3.weforum.org/docs/WEF_Future_of_Jobs. pdf $>$. Acesso em: 27 jan. 2018.

WOOD, Andy. (1993), Efficient Consumer Response. Logistics Information Management, v. 6, issue 4, pp. 38-40. Disponível em: <http://www.emeraldinsight.com/doi/abs/10.1108/EUM0000000002908>. Acesso em: 12 jan. 2018. 


\section{Arquitetura e Urbanismo: Disputas Profissionais e Estratégias de Atuação}

\section{Cristiano Ricardo de Azevedo Pacheco*}

\section{RESUMO}

Este artigo aborda a análise da profissão do arquiteto e seus espaços de atuação, buscando-se definir as circunstâncias sociais, institucionais e políticas de participação profissional em instâncias do mercado de trabalho. Nessa direção, percebe-se que a nova regulamentação profissional dos arquitetos trouxe à tona debates sobre confrontos extraprofissionais e estratégias de reserva de mercado em atividades inerentes à construção civil. Portanto, as discussões, em torno da instalação do Conselho de Arquitetura e Urbanismo (CAU), possibilitam mostrar a luta pela definição dos investimentos para inserção profissional e ascensão na carreira.

Palavras-chave: Arquitetura e Urbanismo. Conflitos Extraprofissionais. Mecanismos Sociais.

* Arquiteto e Urbanista, Mestre em Sociologia (PPGS) e Doutorando em Sociologia pelo Programa de Pós-Graduação em Sociologia - PPGS, da Universidade Federal de Sergipe UFS (Bolsista CAPES). 


\begin{abstract}
ARCHITECTURE AND URBANISM: PROFESSIONAL DISPUTES AND STRATEGIES FOR ACTION
\end{abstract}

This article discusses the analysis of the architect's profession and its spaces of action, seeking to define the social, institutional and political circumstances of professional participation in labor market instances. In this direction, it is noticed that the new professional regulation of the architects brought to the fore debates about extra-professional confrontations and strategies of market reserve in activities inherent to the civil construction. Therefore, the discussions about the installation of the Architecture and Urbanism Council (CAU) make it possible to show the struggle for the definition of investments for professional insertion and career advancement. Keywords: Architecture and Urbanism. Extra-professional Conflicts. Social Mechanisms.

\title{
Introdução
}

Há décadas, existe uma explícita e divulgada disputa mercadológica entre vários atores, de especialidades distintas, envolvidos no ramo da construção civil no Brasil. São exemplos desses conflitos extraprofissionais: litígios, notas de repúdio, grupos de harmonização ${ }^{1}$ e as próprias regulamentações profissionais editadas pelas categorias. Esses confrontos se intensificaram com a recente saída, em 2012, dos arquitetos do Conselho Federal de Engenharia, Arquitetura e Agronomia (CONFEA), e, dessa forma, tal contexto passou a configurar uma tentativa de consolidação do espaço de atuação profissional entre atividades envolvidas no ramo da construção civil. Uma das principais manifestações dessas lutas pode ser observada entre as categorias que fazem sombreamentos ${ }^{2}$ de atividades, em que se encontram diversos registros de disputas litigiosas e mercadológicas no âmbito dos possíveis sombreamentos de atribuições. Portanto, nesse sentido, considera-se que tal situação envolve grupos de profissões e ofícios da construção, envoltos em

1 A Comissão Temática de Harmonização Interconselhos, ajustada entre o CAU/BR e o CONFEA, tem como objetivo analisar e harmonizar as legislações da Arquitetura e Urbanismo e das Engenharias, e solucionar conflitos e sombreamentos nas atividades de cada profissão (CAU/BR, 2016).

2 Termo utilizado pelas profissões que atuam na construção civil e possuem atividades em comum dentro dos campos de atuação de categorias profissionais distintas. 
conflitos extraprofissionais, acentuados após a edição da Resolução $\mathrm{n}^{0} 51^{3}$, de 12 de julho de 2013 do recém-criado Conselho de Arquitetura e Urbanismo do Brasil (CAU/BR).

Nesse contexto, a proposta aqui busca contribuir quanto ao entendimento do jogo na luta pelo monopólio profissional e as possíveis relações políticas e sociais que servem como uma estratégia também de disputa entre grupos e atores, cuja finalidade é a prevalência de atuação no espaço social. Essa competição se intensifica, sobretudo, quando os critérios referentes à profissionalização do ofício estão vinculados ao conhecimento específico, ao credencialismo e à autonomia profissional, pois esses são os pilares que permitem identificar o poder das profissões. No entanto, entende-se que a atribuição da licença e do mandato não é um processo inteiramente pacífico, muitas vezes é uma das fontes principais de conflito e de competitividade ao nível do campo profissional e de ação política (RODRIGUES, 2002).

Diante do contexto de conflito extraprofissional, vê-se o certificado acadêmico como um importante instrumento de distinção dos grupos profissionais, que pode determinar as fronteiras do campo de trabalho de um saber específico. Esse tema ocupa um lugar central na condição de análise de mercado de trabalho dependente das determinações dos critérios de habilitação e exercício de uma específica atividade. Nessa perspectiva, tal investida nos encaminha para o entendimento das estruturas particulares da atividade de arquitetura e urbanismo, mostrando sua política de formação - como a exigência do diploma acadêmico, por exemplo -, que pode servir para garantir a qualidade dos serviços prestados, uma vez que os clientes não dispõem de competências específicas para apreciar o que está sendo oferecido (PARSONS, 1968).

Nesse sentido utilitário, a teoria funcionalista4 traz o entendimento de um perfil de profissão com caráter indispensável à sociedade, devido aos profissionais serem detentores de conhecimentos técnico-científicos específicos. Dessa forma, segundo Dubar (2005), esse processo de interação utilitarista, que se estabelece entre profissional e cliente, gera a institucionalização

3 A Resolução no 51 CAU/BR, editada em 2013, especifica as atividades, as atribuições e os campos de atuação privativos dos arquitetos e urbanistas, os que são compartilhados entre estes e os profissionais legalmente habilitados em outras profissões regulamentas. (CAU/BR).

4 Dentre os autores dessa corrente, podemos citar Parsons como o mais proeminente. Mais detalhes sobre essa perspectiva podem ser encontrados em Rodrigues (2002). 
do processo de profissionalização. Portanto, segundo a análise funcionalista das profissões, uma ocupação só ascende ao status de profissão se atender a alguns critérios mínimos, como a existência do diploma, a regulação a partir das associações profissionais e um consenso normativo, como um código de ética por exemplo (ANGELIN, 2010). Assim, a teoria funcionalista torna-se uma das linhas de estudo utilizadas como suporte complementar ao fundamento teórico desta pesquisa.

A linha interacionista também foi tomada como referência ao aporte de estudo para esta investigação, sobretudo ao destaque que a linha de estudo faz ao definir "grupos profissionais" dentro de um entendimento ampliado, em que as atividades de trabalho são associadas a interações sociais. Para Becker (1997), um dos autores que se destacam nessa abordagem, a análise do investimento na carreira profissional e da socialização profissional possibilita o entendimento dos perfis de carreiras característicos de um ofício. Além disso, ajuda na compreensão do alcance de tal socialização em relação ao acúmulo do conjunto de recursos específicos inerentes aos espaços de atuação. Entretanto, é fundamental associar tais recursos, adquiridos a partir da socialização profissional, com outros diversos, obtidos em espaços sociais variados, tais como movimentos sociais, partidos políticos e a família. Portanto, a análise dos trajetos sociais, escolares e profissionais dos arquitetos contribui para fornecer informações a respeito da importância que assume o diploma frente a outros recursos sociais acumulados a partir dos vínculos familiares, políticos e profissionais.

Portanto, este artigo tem como objetivo esmiuçar o espaço de atuação profissional do arquiteto e urbanista, a partir da compreensão de que esse é um espaço de luta por fatias no mercado de trabalho e, principalmente, da consideração da arquitetura como uma profissão que exerce a prática de monopólio e controle de competências. Logo, elegeu-se um duplo objeto empírico, que consiste, de um lado, nos arquitetos protagonistas atuantes e suas estratégias de investimento profissional, e, de outro, na entidade representativa de classe profissional e seus esforços no sentido de construir um espaço de atuação reservado aos arquitetos. Como protagonistas, entendemos aqueles que ocupam posição de destaque, gerenciamento ou chefia em diferentes espaços de atuação.

Para desempenhar tal tarefa, tornou-se fundamental submeter à análise crítica os arquitetos protagonistas no mercado de trabalho, considerando- 
-se como referência do sentido de protagonismo as informações de cunho socioeconômico existentes no censo ${ }^{5}$ do CAU. Para isso, foram consideradas as informações quanto às "atuações em campos profissionais" e "maiores remunerações individuais”. Tais dados são as diretrizes para configurar o caráter de notoriedade, ao que me refiro aqui como protagonismo. Logo, para atingir tal finalidade, procurou-se observar as peculiaridades sociais daqueles que investiram na arquitetura, em Aracaju/SE, em épocas diversas, situando como referência as características de dois grupos de profissionais. No total, foram entrevistados 14 arquitetos, entre julho a dezembro de 2017, dentre os quais, 7 estão no ranking de maiores emissores de RRTs ${ }^{6}$ do CAU-SE, já os 7 restantes são arquitetos que possuem visibilidade social, através de destaques em mídias específicas da profissão - revistas, programas de TV, outdoors, anuários - e ocupam posições de chefias em órgãos públicos e empresas particulares.

Para realizar a análise do profissional e da atividade de arquitetura e urbanismo, discorreu-se, de forma breve, quanto a sociogênese da profissão, priorizando as peculiaridades do crescimento e posterior queda de autonomia da arquitetura no Brasil. Em seguida, colheram-se as informações do Censo do CAU para determinação dos atores protagonistas na capital sergipana e puderam-se obter, do Conselho, os dados quanto aos arquitetos que se enquadram num contexto de destaque em Aracaju. Tais dados foram obtidos a partir do levantamento dos Registros de Responsabilidade Técnica (RRTs), - emitidos pelos arquitetos na capital sergipana. Obteve-se, com os registros, a locação dos arquitetos nos postos do mercado de trabalho em Aracaju, o que permitiu realizar o cruzamento de informações com finalidade de determinar quem são os profissionais considerados como personagens principais a serem submetidos à abordagem de análise crítica.

A aplicação de entrevistas abertas, junto aos arquitetos protagonistas, e a pesquisa documental em instituições associativas foram as técnicas uti-

5 Censo realizado a partir do cadastro de profissionais do sistema de informação (SICCAU) do Conselho. Com a criação do CAU dos estados e do DF, em 2011, foi proposto um questionário para mais de 99 mil profissionais que se registraram, de forma a promover um recenseamento sobre vários temas inerentes à profissão. Foram mais de 83 mil respostas de todo o Brasil.

6 O Registro de Responsabilidade Técnica é o documento de emissão permitida apenas aos profissionais arquitetos e urbanistas e que comprova que projetos, obras ou serviços técnicos de Arquitetura e Urbanismo possuem um responsável devidamente habilitado e com situação regular perante o Conselho para realizar tais atividades (Cf.: <http://www. caubr.gov.br/1-para-que-serve-o-rrt/>). 
lizadas para a obtenção de resultados quantitativos e qualitativos desta investigação ${ }^{7}$. Também, procedeu-se a observações e acompanhamentos das reuniões e dos eventos que são organizados pelos arquitetos em torno da sua representação profissional, situando as suas falas em contextos mais vastos. Portanto, o CAU, enquanto entidade associativa, estabelece-se como um espaço de relevância para a apuração acerca do seu papel enquanto agente de controle da profissão.

\section{A Ascenção da Arquitetura e Posterior Perda de Autonomia Profissional}

O espaço do mercado de trabalho da Arquitetura no Brasil tem seu momento de estabelecimento fincado nos períodos em que houve a transição da forma de governo imperial para o republicano. Após esse período, a arquitetura passou por uma fase de crescimento que se estendeu por décadas, culminando com a inauguração de Brasília, decorrendo de momentos de transição política e cultural atrelados às circunstâncias de desenvolvimento industrial, inovações tecnológicas e comportamentos artísticos de vanguarda.

Nesse período, antecedente ao regime militar, existia um aspecto otimista, em que se via uma afirmação profissional alcançada pela arquitetura modernista no Brasil. Em uma linguagem vanguardista, surgiu uma definição do perfil profissional, o que contribuiu no estabelecimento de notoriedade para a classe de arquitetos que se formava cada vez mais como um grupo coeso. Foi um período de hegemonia da arquitetura brasileira, num contexto de realizações de obras com caráter excepcional vinculadas ao Estado (DURAND, 1989).

Após a fase que culmina em Brasília, os arquitetos ocuparam bom número de postos em instâncias estatais direta ou indiretamente incumbidas da administração urbana. Mas essa foi uma fase de produção excessiva quanto à nova linguagem dos projetos que poderia estar sujeita às exigências do novo governo militar, às tecnologias industriais e a um mercado imobiliário que se apresentava cada vez mais crescente (DURAND, 1989). Essa circunstância favoreceu a infraestrutura capitalista de um certo número de construtoras de grande porte que podiam se estabelecer, vinculadas aos relacionamentos mercadológicos com o Estado. Com isso, há uma

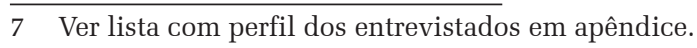


transferência de competências do arquiteto para as empresas e os diretores de canteiros, onde o arquiteto não podia mais negociar soluções técnicas inovadoras, visto que, a fim de resolver certas dificuldades do projeto, ele teve que aceitar as soluções propostas pelas grandes empresas burocratizadas (DURAND, 1989).

Nesse momento, consolidam-se as disputas entre arquitetos e engenheiros no período do regime militar, com a entrada das grandes empreiteiras e a "requisição" política de uma maior tecnicidade industrial do momento. A partir da constituição do CAU em 2010, acirra-se essa batalha e se estabelece uma disputa no âmbito dos questionamentos quanto às atribuições exclusivas do arquiteto, sobretudo à elaboração de projetos de arquitetura. Nessa disputa, as partes envolvidas buscaram analisar as estruturas curriculares dos cursos acadêmicos das duas esferas profissionais e, num fracassado esforço de entendimento entre os dois grupos profissionais, criou-se um litigioso confronto movido pela Federação Nacional dos Arquitetos (FNA) contra o sistema CONFEA/CREA.

Vale sobrelevar que, em alguns países da Europa, também ocorria o declínio de sobreposição da atividade de arquitetura e urbanismo sobre as demais envolvidas no processo construtivo, sobretudo na França, país de origem do sociólogo francês Florent Champy e local em que surgiu a primeira organização associativa e o primeiro código de conduta profissional dos arquitetos. Sociólogo, estudioso do trabalho profissional e das dificuldades inerentes a este, Champy (2011) faz abordagem sob um novo olhar das recentes trajetórias no trabalho, sobretudo quanto à autonomia dos profissionais. Ele tem várias análises sobre a arquitetura e, em seus estudos, apresenta algumas conjunturas do grupo profissional que podem caracterizar a redução do campo de atuação do arquiteto.

Vê-se na França o mesmo percurso ocorrido no Brasil, onde, no passado, o campo profissional era exclusivo dos arquitetos, mas que, gradativamente, foi passando a estabelecer um pé de igualdade com os parceiros das equipes que atendem às demandas de programação de um mercado repleto de especificidades. $\mathrm{O}$ ato de recorrer a esses outros atores justifica-se pela complexidade do projeto, que requer a aplicação de saberes que a arquitetura pode não dispor. Mas, mesmo se não houver a necessidade de tais saberes, os mesmos poderão ser impostos pelo gerenciador de projetos, caso ele os julgue imprescindíveis. 
As intervenções especializadas conheceram uma ampliação notável, caracterizada pelo surgimento de tarefas de criação que não concernem mais apenas aos aspectos técnicos da construção, necessários à observância das exigências da construção, mas, também, aos aspectos atinentes à harmonia e ao equilíbrio das especificidades. Os engenheiros conselheiros e os escritórios de consultoria passaram a se unir, com frequência, aos paisagistas ou aos urbanistas, que se encarregaram de zelar pela boa integração do imóvel ao local; participa ainda, às vezes, um profissional da acústica ou mesmo um decorador para contribuir na definição dos ambientes. Esses novos parceiros adentram, portanto, cada vez mais, na zona restrita do arquiteto (CHAMPY, 2011).

\section{Postos de Atuação em Aracaju}

As informações, contidas no censo CAU/SE, quanto às "atuações em campos profissionais" (Figura 01) e "maiores remunerações individuais" (Figura 02), correspondem às diretrizes para configurar o caráter de notoriedade, ao que me refiro aqui como protagonismo. Sugiro esse critério para identificação do protagonismo pelo fato de estar diretamente relacionado com o tema dessa investigação que envolve uma categoria e sua relação com o mercado de trabalho, objeto de análise da pesquisa.

Figura 1 - Área de atuação nos últimos dois anos em Sergipe

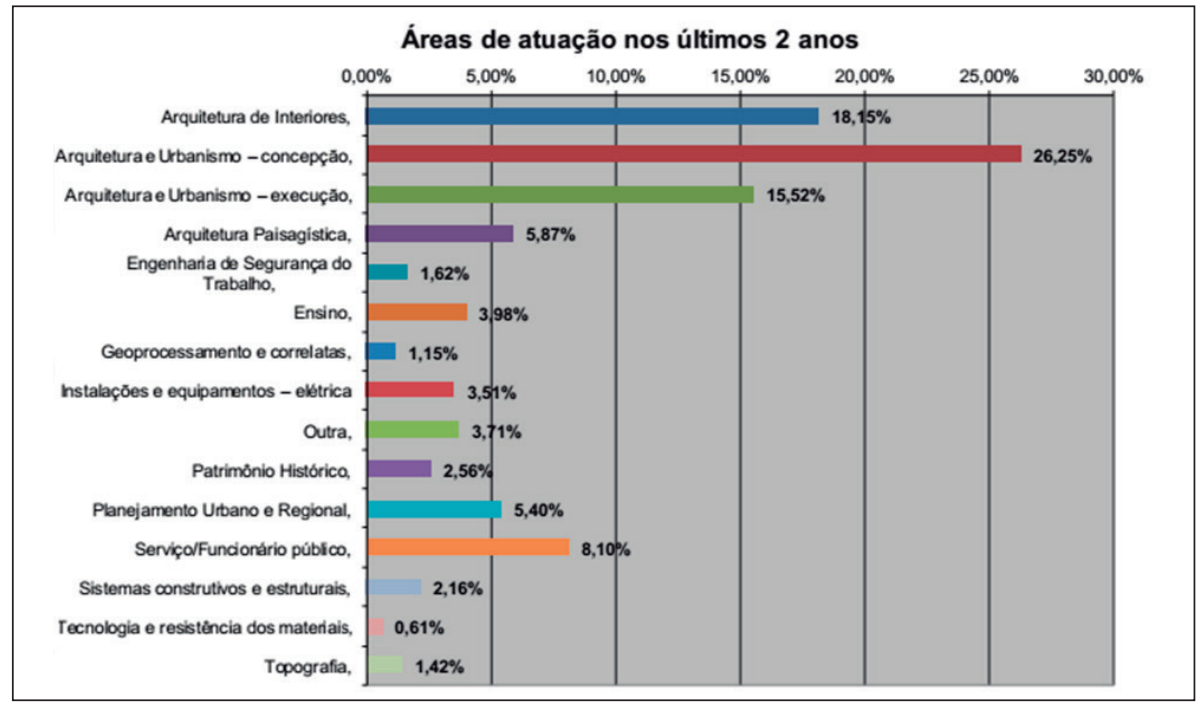

Fonte: Censo CAU/SE, 2012 
Figura 2 - Faixa de renda individual

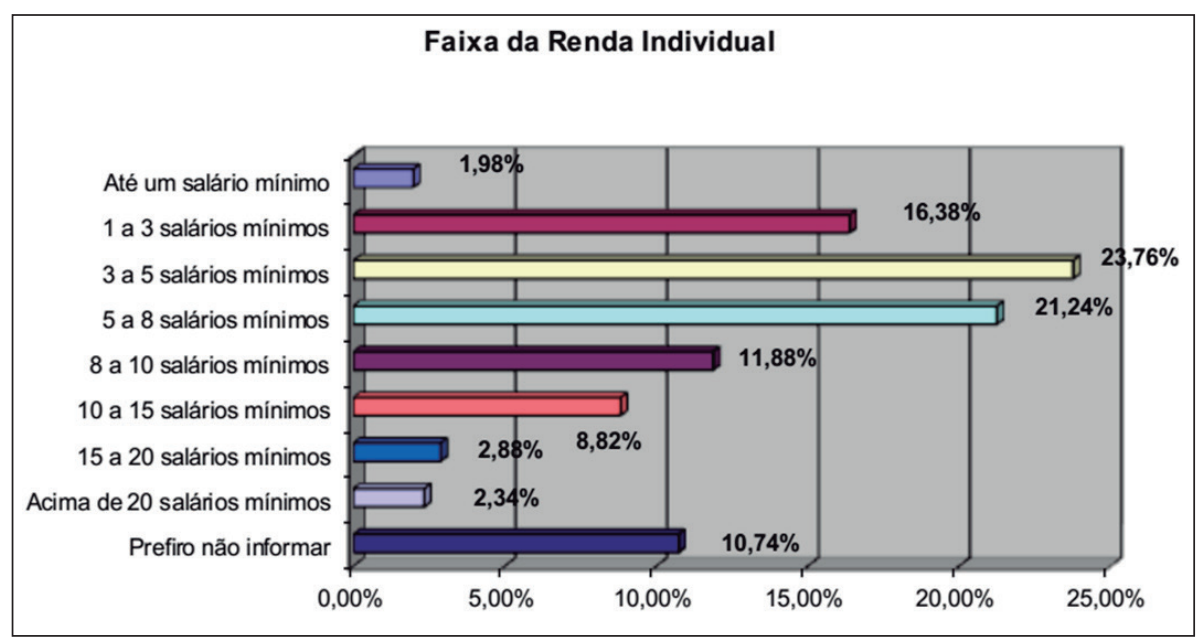

Fonte: Censo CAU/SE, 2012

Na Figura 01, podemos observar as áreas de atuação dos arquitetos sergipanos. Assim, para se fazer um recorte mais claro dos requisitos de notoriedade definidos aqui, consideraram-se os sete maiores campos de atuação que possuem uma maior significância de representatividade das atividades da categoria. Portanto, conforme o censo CAU/SE, verificou-se que: $26,25 \%$ dos profissionais trabalham, majoritariamente, com concepção de projetos; um número menor, mas significativo, 15,52\%, participa regularmente da fase de execução de obras; a arquitetura de interiores é também uma demanda frequente, com $18,15 \%$ dos profissionais dedicados a essa área; pequenas parcelas do total da categoria dedicam-se a atividades como planejamento urbano $(5,40 \%)$, paisagismo (5,87\%) e ensino (3,98\%); e 8,10\% são funcionários do serviço público.

Dos 14 entrevistados considerados, os dados revelam que: 2 recebem entre 5 - 10 salários mínimos mensais ${ }^{8} ; 7$ recebem entre $10-15$; 3 entre 15 - 20; 1 entre 20 - 25 e 1 acima de 30 . Vale aqui uma distinção significante que está associada não só à forma de atuação, como também aos cargos assumidos pelo arquiteto. Os dados obtidos nas entrevistas revelam que os rendimentos mais elevados se concentram nos arquitetos que possuem escritórios de arquitetura. Entretanto, de acordo com o censo do CAU/SE, percebe-se que a grande maioria dos arquitetos não é composta por proprietários de empresas,

8 Este trabalho foi realizado no momento em que o salário mínimo correspondia a 930,00 reais. 
mas por profissionais que trabalham como autônomos, sem estrutura formal de pessoa jurídica. Conforme demonstrado na Figura 03.

Figura 3 - Pessoas jurídicas na área de Arquitetura e Urbanismo em Sergipe

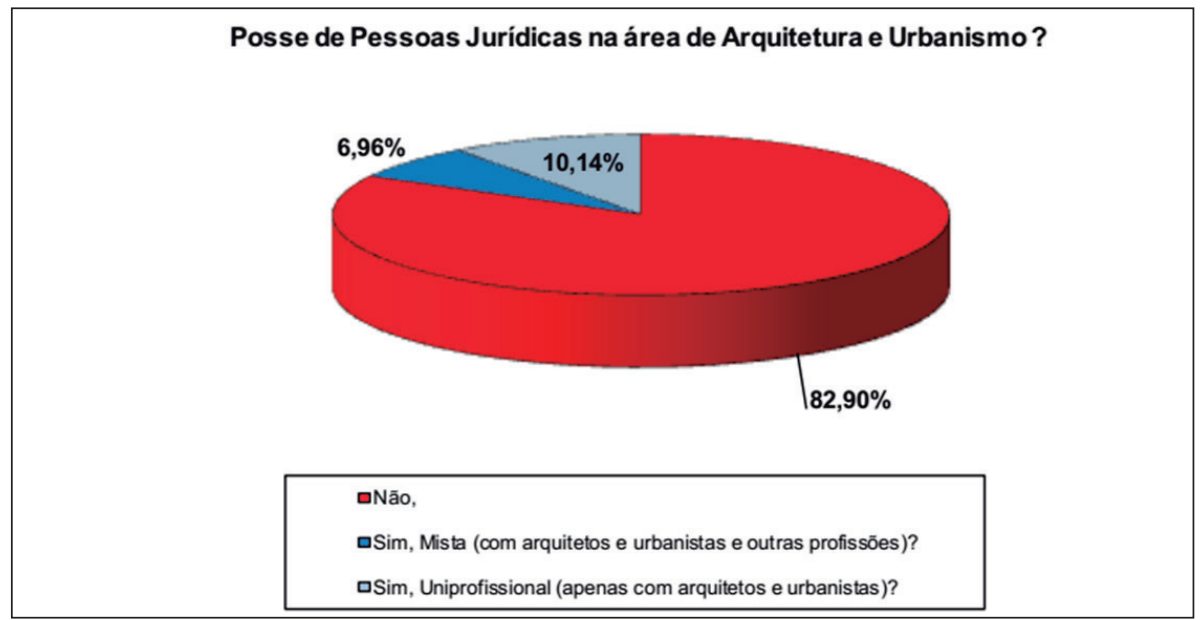

Fonte: Censo CAU/BR, 2012

Na Figura 04, conseguem-se identificar, em destaque, as quatro fontes de renda de maior prática profissional dos arquitetos atuantes em Sergipe. Também se identifica, nesse levantamento, a relação das remunerações com alguns segmentos de atuação profissional. Tais atuações estão em foco neste artigo e confirmam a convergência de análise que está sendo realizada. Conforme a Figura 04, estes são os segmentos de atividades de maior atuação no estado: proprietários de empresas de arquitetura, funcionários públicos e profissionais autônomos.

Figura 4 - Formas de atuação de maior significância no sentido dos rendimentos financeiros na área de Arquitetura e Urbanismo em Sergipe

\begin{tabular}{|c|c|c|}
\hline 6) Fontes de Renda & Quantidade & $\%$ \\
\hline Aposentado / Pensionista & 12 & $1,82 \%$ \\
\hline Setor privado ligado a Arquit/Urb. & 115 & $17,42 \%$ \\
\hline Setor privado NÃO ligado Arquit/Urb. & 4 & $0,61 \%$ \\
\hline Setor público ligado aArquit/Urb. & 122 & $18,48 \%$ \\
\hline Setor público NĀO ligado a Arquit/Urb. & 30 & $4,55 \%$ \\
\hline Autônomo ligado a Arquit/Urbanismo & 218 & $33,03 \%$ \\
\hline Autônomo NẢO ligado a Arquit/Urb. & $17 \mid$ & $2,58 \%$ \\
\hline Empresário ligado a Arquit/Urb. & 74 & $11,21 \%$ \\
\hline Empresário NÂOO ligado a Arquit/Urb. & 29 & $4,39 \%$ \\
\hline Outras fontes & 222 & $3,33 \%$ \\
\hline Renda proveniente de aluguel & 16 & $2,42 \%$ \\
\hline Seguro-desemprego & 1 & $0,15 \%$ \\
\hline TOTAL & 660 & $100,00 \%$ \\
\hline
\end{tabular}

Fonte: Censo CAU/BR, 2012 
Com os RRTs, foi identificada a locação dos arquitetos nos postos do mercado de trabalho em Aracaju; em seguida, realizou-se o cruzamento de informações com finalidade de determinar quem são os profissionais considerados como personagens principais a serem submetidos à abordagem de análise crítica. Realizou-se um diagnóstico sobre os questionários aplicados, com o intuito de compreender as trajetórias dos profissionais que ocupam posição de destaque no mercado de trabalho. Interpretou-se, assim, uma descrição das suas carreiras, buscando apreender aspectos biográficos e confrontando com as informações de distribuição dos arquitetos, fornecidas pelo CAU/SE, nos postos do mercado de trabalho de Aracaju.

\section{Recursos de socialização e trajetos profissionais}

A análise das trajetórias e dos relatos de vida dos arquitetos permite a articulação de temas de características objetivas - ocupação dos pais, escolaridade, cargos, inserção em outras esferas - com as questões de ordem subjetiva - relatos sobre as origens, sobre a entrada na arquitetura, motivos para a escolha do curso. Tais relatos estão relacionados a percepções mais gerais sobre a profissão e sobre a importância que assumem diferentes títulos para o exercício da arquitetura (DUBAR, 2005). A socialização familiar, a socialização profissional e outras formas de socialização constituem formas de acumulação de recursos sociais que podem permitir o acesso a posições profissionais e a ascensão interna na atividade. Assim, considera-se que as fontes de renda, aliadas às atividades de maior importância no universo da categoria, podem ser alcançadas a partir de vários mecanismos de recrutamento, que podem estar associados à criação de redes de relacionamentos, às posições de origens mais altas, à utilização do diploma como um instrumento de destaque social e ao investimento em atividades que produzem maior visibilidade social e retornos financeiros. Nesse aspecto, identificaremos, a seguir, as formas de utilização desses variados recursos que contribuem para a inserção e formação da hierarquia interna do mercado de trabalho do arquiteto e urbanista. 


\subsection{Origens sociais}

Com relação à profissão do pai, os dados coletados apontam que: 50\% são funcionários públicos, 40\% são comerciantes e 10\% são funcionários de empresas particulares. Quanto ao nível de escolaridade do pai, 57,1\% têm o segundo grau, 28,6\% o primeiro grau e 14,3\% o nível superior. Já quanto à profissão da mãe, 64,3\% são donas de casa, 21,4\% funcionárias públicas e $4,33 \%$ são envolvidas com política; e quanto ao grau de escolaridade dessas, $78,6 \%$ possuem o primeiro grau, $14,3 \%$ terminaram o segundo grau e $7,1 \%$ têm ensino superior.

Esses dados mostram que a maioria dos arquitetos possui pais que exercem funções que não precisam de formação escolar e que no conjunto têm uma baixa escolarização. Contudo, para essas informações passarem a ter relevância no estudo da ocupação de cargos na arquitetura e urbanismo e ascendência na estrutura da profissão, é preciso estabelecer relações com a posição atual ocupada na arquitetura, em empresas privadas e no órgão público a que pertence o arquiteto. Daqueles que ocupam posição de cargo de livre provimento e chefia honorífica, 7 ao todo, 3 são filhos de comerciantes, e 4 são filhos de funcionários públicos. Desses profissionais que ocupam cargos de funcionalismo público, estão os $50 \%$ dos pais que possuem até o segundo grau de formação escolar. Do total, 14 casos, somente há 1 caso em que a mãe possui nível superior. Nesse caso, o profissional é ocupante de um dos maiores cargos públicos de relevância na cidade. Quanto à formação dos pais, 8 apresentam segundo grau completo, 5 deles são pais de arquitetos funcionários públicos.

Ademais, da circunstância dos pais com segundo grau completo representarem os ocupantes de cargos de chefia pública, faz-se necessário aliar esses dados ao órgão público ao qual esses profissionais estão vinculados. As instituições em que aparecem os arquitetos como ocupantes no quadro de chefias públicas são as seguintes: prefeituras - órgãos de licenciamento de obras, secretarias de planejamento etc. -, o Instituto Banese ${ }^{9}$ e o CAU/ SE. Nessas instituições, existem 7 arquitetos cujos pais finalizaram o segundo grau completo e apenas 1 pai possui o primeiro grau. Isso indica

9 Instituição vinculada ao Governo do Estado de Sergipe, que tem como propósito promover ações de valorização da diversidade do patrimônio artístico-cultural e imaterial do estado. 
que, quanto maior a posição ocupada pelo arquiteto nos órgãos públicos, maior são os níveis de formação escolar e de profissão dos pais dos ocupantes de cargos de chefia pública. Portanto, nota-se uma homologia entre a posição ocupada no espaço profissional e a posição de origem, como sugere Bourdieu (1989), ao ver determinados recursos que são associados à família, ao econômico e à política, como constituintes de um mecanismo de distinção social.

A socialização familiar exerce um papel fundamental para a obtenção de uma posição social e profissional elevada. Trata-se de uma condição de legado cultural adquirido pelos meios de "prestígio social" associados às origens sociais do arquiteto. Portanto, a família e a posição de origem podem contribuir não só na definição social do indivíduo, como também na seleção entre membros de um mesmo grupo social e familiar. Dessa forma, o reconhecimento das origens sociais pode constituir um artifício para compreender a ocupação de algumas posições de relevância profissional.

\subsection{Mecanismos de inserção e atuação profissional}

O estágio, em construtoras, órgãos públicos e escritórios de arquitetura, apresenta-se como uma importante etapa no trajeto de ingresso na carreira profissional, sobretudo a ser realizado na formação universitária, momento em que as redes de relacionamento têm uma tendência a serem estabelecidas. O estágio pode ser considerado como componente do conjunto de artifícios para as inserções sociais, pois ele contribui com o acúmulo de recursos que podem ser transformados em posições profissionais e destaques de oportunidades de trabalho. Portanto, o estágio é visto como um investimento na atmosfera de iniciação no mercado de trabalho e, dessa forma, pode se tornar de fundamental importância para a obtenção de recursos sociais que ajudam a ampliar os espaços de atuação profissional.

O relato abaixo, de um dos arquitetos entrevistados, ilustra a importância que assume a socialização profissional a partir do ingresso nos estágios, sobretudo quanto à constituição das redes de relacionamentos que contribuem tanto para a constituição da formação profissional, antes e após a titulação acadêmica, como para a projeção dos trabalhos de visibilidade no mercado de trabalho do arquiteto: 
O estágio foi fundamental para eu me manter em Salvador. Eu estagiei e ganhava meio salário mínimo, pois eram quatro horas por dia, quando chegou nas férias eu comecei a trabalhar o dia todo e meu salário aumentou e ao retornar das férias permaneci nesse horário. Era estágio no escritório de Ricardo Freire ${ }^{10}$, onde fiquei um ano e meio porque eu comecei a fazer meus projetos para amigos em Aracaju, foi quando fiz o meu primeiro projeto, como estudante ainda, para um funcionário do Banco do Brasil, que mostrou para os amigos, que gostaram da casa e me chamaram para fazer as casas deles também. [...]. Foi quando resolvi sair do estágio porque não estava mais dando conta de tanta coisa, foi quando ele disse que estava pensando em me propor sociedade no escritório, mas eu não queria. Eu estava projetando para os amigos de meus irmãos mais velhos que eram funcionários públicos e aí quando eu me formei eu já me sustentava tranquilamente, pois já tinha uma clientela e vivia por conta própria [...] (Entrevista 3).

Essa fala demonstra que os espaços são conquistados antes mesmo da obtenção do diploma e o fato de que, apenas a apresentação como um estudante de arquitetura, torna possível o ingresso em estágios que proporcionam um movimento expressivo na socialização do candidato ao ingresso na área. Dessa forma, essa socialização indica que não é apenas por meio do título acadêmico que se ocupam os espaços, pois quando se obtém o diploma já se tem um conjunto de relações e contatos definidos.

Os dados coletados mostram que uma forma muito comum de entrada na profissão e possível ascensão na hierarquia ocorre através de indicações para a ocupação de cargos públicos, como chefias e diretorias de instituições do estado. A procura por ocupação nessas funções é muito intensa, pois os salários são altos e a permanência no período de gestão política é garantida, já que as indicações para a posse dessas colocações são realizadas por amigos próximos e, em alguns casos, por parentes. O prestígio das redes de relacionamentos é considerado como uma abertura na inserção desse mercado e as "influências" quanto às amizades e conhecidos são uma via determinante para a ascensão de postos de atuação, como, por exemplo, o progresso de estagiário para ocupação direta em um cargo de chefia ou diretoria pública.

10 Nome fictício. 
[...]. Eu entrei aqui, eu acho que estava no sexto período, coloquei o currículo debaixo do braço, vim fazer uma entrevista com a diretora, ela era coordenadora ainda, não era nem diretora na época, e aí conversando com ela, e ela percebeu meu nome, que é singular, e ela lembrou do pai e disse que conhecia meu avô, ela conhecia minha família e, aí, acho que ela se sensibilizou e deu a oportunidade de estagiar. $\mathrm{Na}$ mesma época, eu consegui um trabalho no tribunal de contas, onde recebia muito mais [...], mas eu preferi vir para cá que é minha área, vou ganhar menos, mas eu vou aprender e foi o que aconteceu, até hoje eu estou por aqui e hoje como diretor. (Entrevista 4).

Em muitos casos, são as necessidades comerciais que determinam a continuidade de ocupação no cargo público e são definidas via "atendimentos" de demandas que as relações de amizades estabelecem. Essas são situações que, corriqueiramente, acontecem em momentos de alternância da gestão pública, com a troca de secretários municipais. Por consequência, as indicações de "amigos" para as ocupações de cargos de confiança acontecem associadas aos favores que são concedidos em forma de contrapartida. Exemplo disso são as "desburocratizações" de processos, de empresas, dependentes de aprovações em órgãos públicos municipais.

Vejamos o que um dos entrevistados relatou quanto à sua experiência na ocupação de um cargo público de confiança e como ele lida com as questões de desburocratização na relação de trabalho. Vale destacar que o profissional interrogado ascendeu de cargo a partir de seu ingresso no estágio.

Eu acho que hoje eu cheguei aonde eu queria que é chegar à diretoria [...], você estar à frente [...] de estar comandando [...] aí você começa a sentir essa importância [...] se você disser: você tem influência? Eu vou dizer: tenho; não vou dizer que eu não tenho, hoje eu tenho influência, tanto é que eu continuei por influência, influência no meio político, porque a gente vai conhecendo as pessoas, eu sempre fui uma pessoa de me relacionar muito bem com todo mundo, não tenho inimigo. Minha rede de relacionamentos foi tudo fruto do trabalho das pessoas verem o trabalho andar, fluir, desburocratizar dentro da medida do possível. O que eu escuto muito deles é que [...] isso aqui não existe se não tiver o bom senso, senão trava [...] (Entrevista 4).

Conforme observado, o órgão público representa, para o universo da arquitetura e urbanismo, um potencial trajeto de inserção no mercado de 
trabalho, e, nessa perspectiva, a intenção de penetração nesse circuito da atmosfera pública torna-se cada vez mais forte, pois é um espaço envolto numa diversidade de agentes que produzem fortes possibilidades de ascensão profissional. Nessa direção, vários aspectos de crescimento profissional podem surgir, como por exemplo a estabilidade financeira dos escritórios de arquitetura e urbanismo, o encadeamento contratual com órgãos públicos e a inserção em grandes construtoras/empresas, para assumir cargos de chefia. O relato abaixo fornece alguns elementos para observarmos essa relação.

Eu mesmo, quando eu me formei, eu fui convidado para trabalhar no serviço público. Aí, fui contratado [...]. O chefe que me convidou era meu cliente e eu tinha feito a casa dele e ele me conheceu, gostou da casa e aí me chamou. Ele me contratou e viabilizou esse negócio porque pelo governo de estado não podia contratar porque tinha que ter o concurso. [...] eu me formei em dezembro de 1988, em março de 1989 eu já estava lá. Eu estava fazendo meus projetos em casa e não tinha capacidade para montar um escritório e tudo mais, e eu fazia em casa, não tinha despesa, estava começando e aí eu tinha esse receio, não sabia como era o mercado, então apareceu esse serviço e achei ótimo, eu tinha um emprego garantido ali [...]. Eu trabalhava o dia todo lá e à noite fazia meus projetos [...]. O "boom" do trabalho foi nesse sentindo, fazendo residências para funcionários públicos [...], aí eu pedi uma licença sem rendimentos pra me garantir, pra ver se ia dar certo. [...]. Então, pedi minha licença com validade de dois anos e me dediquei totalmente ao escritório, no término de dois anos eu pedi demissão. Não voltei mais e o escritório se estabeleceu. (Entrevista 3).

O caminho de chegada ao cargo público é estabelecido por várias possibilidades de acesso e, em muitos casos, o contato cotidiano do profissional com o órgão público torna-se, até certo ponto, inevitável devido à necessidade do aval técnico do Estado. Nesse sentido, os escritórios e construtoras, que têm a necessidade de interação com as regulamentações de ordem pública, precisam manter um intenso contato com as diretrizes de construção, que se originam desses órgãos. Nessa aproximação com os setores públicos em que estão envolvidas as atividades de arquitetura, o agente que faz a intermediação dos processos estabelece "conhecidos" que passam a compor uma rede de relacionamentos. Com isso, tal rede passa a contribuir com o 
agenciamento de uma possível inserção e ascensão da vida profissional do arquiteto dentro do órgão público onde foram criados diversos contatos.

[...] A Construtora ganhava a licitação e passava os trabalhos para eu desenvolver, na realidade eu fazia mais do que só projetar, [...]. Aí, eu comecei a ter contato com pessoas da prefeitura, [...], Samuel Vaca ${ }^{11}$ era o presidente na época, ele gostou do meu trabalho e, ao invés de pagar a obra na Construtora, ele simplesmente me chamou para fazer o mesmo que eu fazia lá, só que eu fazia para a própria prefeitura, ao invés dele pagar para a empresa desenvolver, botou um profissional dentro da própria prefeitura que desenvolvesse isso. [...]. Eu era a técnica do setor, até depois disso, em alguns momentos, eu cheguei a exercer funções de chefia [...]. (Entrevista 1).

Soma-se aos critérios de formação para ocupação de cargos de relevância o fato de os arquitetos protagonistas possuírem uma origem social mais elevada vinculada a perfis de ordem política. Nota-se que a definição considerada fundamental para o exercício da profissão passa pela família e o que ela proporciona em termos de acesso a certos recursos. Mas existem recursos vinculados aos sobrenomes das famílias que perpassam pelas necessidades de avaliação para a entrada ou não nos cargos de ocupação pública. De qualquer forma, a família e suas relações se tornam importantes para o exercício da arquitetura. Ao ser questionado quanto à influência do sobrenome político em sua carreira, o entrevistado, cujo fragmento de entrevista é citado adiante, relata a importância da presença política para a imersão e ascensão na arquitetura e urbanismo.

[...] o meu sobrenome tem uma coisa aí meio dúbia, porque quando meu primo ainda não estava no poder queriam cercear a minha atuação porque diziam que meu sobrenome era da oposição, mas eu sempre soube lidar com isso e sempre tive o respeito das duas partes, da situação e da oposição, então mesmo no governo oposto eu trabalhei [...]. Não posso dizer que meu sobrenome me atrapalhou, mas incomodou muita gente [...], não só pelo fato de meu primo ter sido um expoente aqui em Sergipe, e eu acho que o nome dele sempre esteve associado também à seriedade, à honestidade, então eu acho que esse legado, [...] como ele foi a pessoa que mais se projetou na nossa família, ele deixou também esse legado para a gente. [...]. (Entrevista 5).

11 Nome fictício. 
Para os profissionais com origens sociais mais baixas, a vivência na faculdade não é apenas o determinante para a formação de conhecimentos, mas também para se fazerem os primeiros contatos, com professores atuantes no mercado de trabalho, que o possibilitarão ingressar nos estágios que serão a porta de entrada para as efetivações em empregos e captação de futuros clientes. Vejamos um extrato do diálogo em que um dos entrevistados demonstra sua impressão quanto à formação acadêmica superior e a relação que ele faz com a prática profissional. Vale ressaltar que esse arquiteto permanece há treze anos trabalhando em cargo público comissionado.

[...]. Meu conhecimento em arquitetura e urbanismo [...] para dizer assim, de zero a dez [...], eu acho que quarenta por cento do meu conhecimento foi da Unit ${ }^{12}$ e o restante daqui. O meu tempo todo foi dedicado aqui, e na Unit eu nunca fui desses alunos pra dizer que eu sempre fui dedicado, agora, a partir do momento que eu comecei a pagar minha faculdade, os valores são outros e aí você tem que correr atrás [...] e eu nunca tive dúvida de que o que eu quisesse ser ia depender do meu desempenho profissional [...], e também chega um momento que você vê que a faculdade já não agrega mais nada, só lhe consome, só lhe suga [...]. (Entrevista 4).

Aqueles que se colocam defensores do diploma como constituinte da qualificação e habilitação profissional indicam o currículo acadêmico como essencial para evitar a entrada de novos atores no mercado de trabalho, "restrito", dos arquitetos e urbanistas. Constitui-se, então, como uma estrutura de poder para a profissão, poder baseado na expertise, garantido pelo controle profissional e renovado pela confiança entre o profissional e o cliente. Inclusive, nesse aspecto, há um discurso comparativo da trajetória da arquitetura com outras profissões que requerem uma especialização acadêmica ou profissional, como a medicina e o direito. Vejamos:

A importância da grade é imensa, mas o resultado prático tem sido nenhum, as faculdades não têm uma personalidade muito bem definida [...], por que que você acha que os médicos são valorizados? Uma coisa que eu sempre achei interessante é que realmente se a gente tivesse a prova de título, como tem uma $\mathrm{OAB}$, como tem na medicina [...], é uma

12 Universidade Tiradentes. 
diferença que faz os médicos e os advogados serem mais respeitados inclusive, porque os advogados saem generalistas, mas normalmente ele vai buscar uma formação complementar para atuar em alguma área, você tem o advogado criminalista, civil, patrimonialista, de direitos autorais, enfim, você tem várias formações específicas dentro da área, dificilmente você encontra um escritório de advocacia generalista e normalmente escritório de arquitetura atira para todos os lados [...], essa competição antropofágica que a gente tem é complicada. (Entrevista 1).

Por fim, permite-se aqui mostrar o quanto as características daqueles que investiram em arquitetura, em termos de recursos sociais acumulados, contribuem para consolidar um capital de relações sociais fundamentais para a entrada na arquitetura. Dessa forma, por intermédio de modelos analíticos e resultados de investigações empíricas, destacam-se aqui abordagens fundamentais para a análise sociológica das profissões e das ocupações, apresentando os estudos aqui realizados como instrumentos importantes para a leitura das plurais recomposições sociais, econômicas e culturais que atravessam o mundo do trabalho nas atuais sociedades globalizadas.

\section{A influência do CAU e a percepção dos Arquitetos quanto às questões de sombreamento e jurisdição profissional}

Assim como o diploma, o conselho de classe também necessita de vinculações com outras esferas e instrumentos de recursos. Essa condição faz-se necessária para que esse órgão possa se estabelecer enquanto entidade de ações coletivas comunitárias que compartilha valores e ocasiona a união e valorização profissional. Portanto, a análise, que aqui tem merecido atenção, está relacionada com as relações macrossociais determinadas pelo CAU. Nesse aspecto, abordam-se questões que transformam a profissão em agente do poder e levantam-se questionamentos quanto aos processos que ocorrem no interior das associações, buscando-se entender os interesses que estão subjacentes.

A nova lei de regulamentação e suas recém-criadas resoluções - Resolução $\mathrm{n}^{0} 51$ CAU/BR e o código de ética - acirraram processos de divergências com outras profissões, como também consequentes divisões internas do grupo profissional de arquitetos e urbanistas. Dessa forma, percebe-se que as intenções quanto à criação do conselho vão além dos critérios que estabelecem 
as autarquias federais, mas também estão relacionadas com as questões de reserva de mercado e limite de jurisdição e poder.

As questões de sombreamento nas profissões e nas ocupações relacionadas à área de construção civil são discutidas há anos, mas as disputas litigiosas e consequente acirramento da discussão passaram a ocorrer a partir da existência do Conselho de Arquitetura e Urbanismo. Tal situação, já comentada no início deste artigo, tornou-se condição para enfrentamentos, sobretudo quando se tem a intenção de determinar os limites de atuação dos grupos de profissionais que se enveredaram nessa dinâmica.

Esse tema está envolto em opiniões favoráveis e contrárias quanto às possibilidades e necessidades de consenso extraprofissional, pois nessa condição estão acrescidos outros interesses que vão além da limitação de entrada de novos atores. Opostos ao posicionamento de tolher a inserção de outros atores em áreas consideradas restritas pelo Conselho de Arquitetura, existem aqueles que veem com naturalidade a diversidade de especialidades atuando em projetos de arquitetura. Esse posicionamento vem à tona a partir de um momento em que o mercado de arquitetura parece se tornar retraído por diversos fatores e que o tornaram cada vez mais restrito.

No grupo de entrevistados, $57,1 \%$ desses são favoráveis ao sombreamento; $28,6 \%$ são contra e $14,3 \%$ não opinaram nem a favor nem contra, mas consideraram que as atribuições devem ser delimitadas pelas entidades de classe.

Tabela 1 - Relação das formas de atuação profissional prioritárias e opinião quanto aos sombreamentos

\begin{tabular}{|c|c|c|c|c|c|c|c|c|c|}
\hline \multicolumn{10}{|c|}{ FORMAS DE ATUAÇÃO PROFISSIONAL PRIORITÁRIAS E SOMBREAMENTOS } \\
\hline & & \multicolumn{4}{|c|}{ Atuação do Arquiteto } & \multirow[b]{2}{*}{ Frequência } & \multirow[b]{2}{*}{ Total } & \multirow[b]{2}{*}{ Percentual } & \multirow[b]{2}{*}{ Total } \\
\hline & & AUTÔNOMO & $\begin{array}{l}\text { ESCRITÓRIO / } \\
\text { EMPRESA }\end{array}$ & $\begin{array}{l}\text { FUNCIONÁRIO } \\
\text { PÚBLICO }\end{array}$ & PROFESSOR & & & & \\
\hline \multirow{3}{*}{ Opinião } & A favor & 1 & 6 & & & 7 & \multirow{3}{*}{14} & $57,1 \%$ & \multirow{3}{*}{$100 \%$} \\
\hline & Contra & & 2 & & 2 & 4 & & $28,6 \%$ & \\
\hline & $\begin{array}{c}\text { Não } \\
\text { opin ou }\end{array}$ & & & 3 & & 3 & & $14,3 \%$ & \\
\hline
\end{tabular}

Nota: Tabela elaborada a partir dos dados obtidos nas entrevistas

Vale destacar as relações que a atribuição específica da atividade de arquitetura estabelece com as opiniões quanto às questões de sombreamento. Portanto, as formas de atuação são fundamentais na determinação de quem se posiciona contra ou a favor. Nesse aspecto, percebe-se que algumas atividades de arquitetura possuem uma ligação direta com as práticas de atividades articuladas com outras profissões. Assim sendo, vejamos como 
acontecem tais relações com as atividades realizadas pelos arquitetos entrevistados: dos casos favoráveis, 5 atuam com elaboração de projetos complementares, 2 trabalham com projetos de interiores e 1 é paisagista; dos casos em que não foi emitida qualquer opinião a respeito, todos os 2 são funcionários públicos; dos entrevistados que são contra, 1 trabalha apenas com projeto de arquitetura, 2 são professores universitários e são conselheiros do CAU/SE e 1 trabalha com arquitetura de interiores. Esse último declarou que sua atuação está reduzida em $80 \%$ por conta do sombreamento.

De 0 a 100, acho que caiu uns $80 \%$, eu tinha um número fantástico de clientes, do início da carreira até uns três anos atrás, [...], tinha um número muito grande, tipo assim, vinte a trinta clientes por mês, hoje em dia tenho no máximo três clientes por mês, e os clientes estão cada vez mais exigentes, não é como antigamente, não é como antigamente que faziam orçamento com a gente e aí não tinha tanta opção como hoje tem, de profissional formado [...]. (Entrevista 7).

Esse mesmo entrevistado também afirma que, mesmo com a formação e estabelecimento da rede de relacionamentos, o contato com o cliente tem sido quebrado a partir da inserção de novos atores que articulam entrar no mercado de trabalho com valores de projetos mais baratos. Isso indica que o capital social nem sempre é o fator principal de permanência no mercado, já que os interesses financeiros se sobrepõem aos interesses utilitários e de relacionamentos.

[...] Na verdade, a gente foi em várias construtoras, mas a maioria fechou as portas para gente, nem deram importância, e aí essa construtora que foi a FFB, abriu as portas para a gente [...] eles já estavam com o empreendimento pronto, a gente se ofereceu a fazer esse decorado de graça, pois a gente queria mostrar nosso trabalho para eles verem o que iam achar [...]. A gente pegou uma amizade muito grande lá dentro, mas depois desse último empreendimento, a gente só fez uma parte dele e aí ele cismou, não teve jeito e ele deu continuidade com outro profissional mais barato [...]. (Entrevista 7).

Os entrevistados favoráveis ao sombreamento, todos, trabalham com atividades que não são restritas ao projeto de arquitetura, abrangendo atribuições que, no mercado de trabalho, também dialogam com outras áreas, como engenharia civil, decoração e paisagismo. Já os que são con- 
tra se dividem entre conselheiros estaduais do CAU/SE e atuantes na arquitetura de interiores. Portanto, é um grupo formado por ativistas na defesa da restrição de atribuições e por profissionais atuantes no segmento da arquitetura de interiores e que responsabilizam a retração de atuação ao sombreamento com os designers de interiores. Logo, percebe-se que, ao defenderem ou serem contra o sombreamento, os arquitetos estão defendendo o seu espaço de atuação individual, receando a redução de sua abrangência de trabalho. Um dos arquitetos que trabalha com arquitetura de interiores afirmou:

A pessoa que vai contratar um arquiteto não deve contratar um charlatão, tem que contratar uma pessoa que tenha conhecimento, quer dizer, teoricamente, que pelo menos passou na escola, recebeu o diploma. Eu acho que tem que existir o conselho. O CAU tem que trabalhar mais [...] começou recentemente [...], mas acho que o CAU tem que trabalhar mais no sentido de fortalecer a profissão e não perseguir. Tem que entender o mercado, como está o mercado e não simplesmente ficar num pedestal julgando e condenando. Tentar regularizar o mercado, é isso que precisa ser feito, isso é o CAU. (Entrevista 3).

A intenção de criação dos limites de jurisdição não parece ser um interesse coletivo de classe, pois o grau de importância dedicado às questões, relacionadas com os sombreamentos, é determinado a partir de requisitos individuais que podem afetar diretamente a forma particular de atuação do profissional de arquitetura. Dessa forma, dentro do grupo de profissionais arquitetos, são formados outros grupos que passam a se posicionar de acordo com as formas de atuação de cada grupo restrito. Portanto, a fonte de renda e a forma de atuação profissional são critérios fundamentais para determinarem as "bandeiras defendidas" quanto a ser contrário ou a favor do sombreamento.

Portanto, percebe-se que as informações a respeito das intenções profissionais individuais e das consequentes divisões internas da categoria dos arquitetos são as percepções quanto aos reais fundamentos básicos de conflitos sobre os sombreamentos das atividades inerentes ao campo da construção civil. Contudo, essa relação é associada às formas de atuação e fontes de renda dos profissionais, portanto existe uma conexão entre as trajetórias de atuação profissional e as vantagens pessoais profissionais que o ponto de 
vista ocasionará. Assim, tais informações levam a formular que a ideia segundo a qual, quanto maior o estabelecimento dos rendimentos financeiros e quanto maior a abrangência de atuação em diversas áreas da arquitetura, menos o sombreamento será um problema para a categoria.

\section{Considerações finais}

Este artigo constituiu-se na busca de uma contribuição para a Sociologia, no que concerne a ajudar a compreender mais acerca de questões atinentes à profissão de arquitetura e urbanismo, mais especificamente, no entendimento das dinâmicas sociais de formação do grupo profissional. Os confrontos extraprofissionais para imposição de atuação de atribuições de profissões distintas foram reveladores não apenas de uma luta por espaço no mercado de trabalho, mas também possibilitam mostrar uma divisão interna, entre os pares arquitetos, estimulada por diversificações de opiniões quanto às formas e condutas de atuação no mercado de trabalho. As declarações, nas entrevistas, foram também significativas, no sentido de que expuseram os reais interesses que estão por trás dos discursos de defesa e ataque à lei de regulamentação profissional dos arquitetos. Nessa esfera, o conselho de classe se apresentou como um instrumento de edição de recursos vinculados ao poder de determinação das relações no campo de atuação da profissão. Foi justamente, nessa condição, que as opiniões favoráveis e contra a nova lei de regulamentação se instalaram e, assim, as disputas internas foram evidenciadas.

A análise das trajetórias mostrou que o exercício da atividade de arquitetura e urbanismo apresenta-se associado à competência de aplicação em diversas áreas de atividade e que essa condição proativa é determinante para o êxito na trajetória profissional. Ademais, várias informações relevantes foram encontradas em um mesmo percurso em conjunto, o que permitiu compreender a história coletiva da arquitetura, e, dessa forma, reconhecer os recursos que descrevem os investimentos na profissão de arquitetura e urbanismo.

A profissão é um espaço de confronto por uma reserva de mercado e o local de disputa entre estruturas de atuação profissional; portanto, a análise dos conflitos, em torno do mercado de trabalho do arquiteto, permite mostrar que o que está em disputa é a definição das formas e condutas de atuação 
que podem ser utilizadas para inserção e ascensão na arquitetura. Mas vale ressaltar que não são apenas as afinidades de atuação que compõem esse grupo profissional, mas também os amigos ou conhecidos com os quais o arquiteto possui laços, ou seja, elos familiares ou as relações estabelecidas no período de estudo universitário e na trajetória de trabalho.

Com a saída dos arquitetos do CREA e a subsequente criação do CAU e da Lei 12.378/10, cria-se um cenário envolto em processos que a profissão articula para tentar controlar o mercado de trabalho. Além disso, existe também a expectativa de impor os recursos e as concepções legítimas da profissão. É o que acontece a partir da edição da Resolução $\mathrm{n}^{0} 51$, que estabelece as atividades privativas da atividade de arquitetura e urbanismo.

A compreensão das manifestações dos arquitetos a favor ou contra as ações do novo conselho permitiu mostrar que os propósitos profissionais individuais e de grupos específicos representam estratégias para ampliação dos espaços nos quais os arquitetos atuam no momento. Ou seja, o que determina os posicionamentos quanto ao novo conselho é o alcance de interferência da autonomia da autarquia e as possíveis consequências mercadológicas na profissão. As informações levantadas a partir da realização das entrevistas permitiram perceber que o discurso, em defesa da nova lei de regulamentação, está associado à necessidade de valorização profissional, bem como ao controle de entrada de novos atores no campo de atuação dos profissionais. Essa argumentação parece estar vinculada aos arquitetos com perfil mais de defesa nas suas questões regulamentares, dos seus vínculos empregatícios.

Conclui-se que a administração das relações é fundamental ao longo da vida profissional, e os recursos de inserção e ascendência profissional, referenciados anteriormente, são fundamentais para isso. Por meio da análise da carreira dos arquitetos e sua principal entidade representativa profissional, foi possível constatar a existência, no universo da profissão de arquiteto e urbanista, de um processo de reconversão de capital social, movido pelo exercício do saber técnico num âmbito político e de disputas. Tem-se também a concepção dos moldes capitalistas em elementos de produção da arquitetura, e que envolve o trabalho do arquiteto estabelecido no exercício de atividades que vão além de serviços de arquitetura.

Portanto, este estudo concedeu uma melhor perspectiva de compreensão da profissão de arquiteto e urbanista, e esse entendimento foi se tornando 
mais consistente muito em razão da escuta dos arquitetos entrevistados, que expuseram suas concepções a respeito das divergências nas formas de participação no mercado de trabalho, contribuindo assim para a reflexão da formação das profissões. Desse modo, este artigo constituiu colaborações significativas para a reflexão da composição das profissões e das teorias quanto à profissionalização e mercado de trabalho.

\section{Referências bibliográficas}

ANGELIN, Paulo E. (2010), Profissionalismo e Profissão: Teorias Sociológicas e o Processo de Profissionalização no Brasil. REDD - Revista Espaço de Diálogo e Desconexão, v. 3, n. 1.

BECKER, Howard S. (1997), Introdução: Métodos de Pesquisa. In: BECKER, Howard S. Métodos de Pesquisa em Ciências Sociais. São Paulo: Hucitec. pp. 9-16.

BOURDIEU, Pierre. (1989), O Poder Simbólico. 2 ed. Rio de Janeiro: Bertrand Russel.

CHAMPY, Florent. (2011), La vulnérabilité du travail professionnel. In: CHAMPY, Florent. Nouvelle théorie sociologique des professions. Paris: Presses Universitaires de France. pp. 209-252.

DUBAR, Claude. (2005), A socialização: construção das identidades sociais e profissionais. 1 ed. Portugal: Porto Editora.

DURAND, José C. (1989), Arte, privilégio e distinção (artes plásticas, arquitetura e classe dirigente no Brasil, 1855-1985). 1 ed. São Paulo: Perspectiva.

PARSONS, Talcott. (1968), "Professions”. In: SILLS, David L.; MERTON, Robert King. International Encyclopedia of the Social Sciences. New York: Free P. pp. 536-547.

RODRIGUES, Maria L. (2002), Sociologia das Profissões. 2 ed. Portugal: Celta. 


\section{APÊNDICE: LISTA DAS ENTREVISTAS}

Organização das entrevistas realizadas por: sexo, idade, emprego, forma de atuação na arquitetura e urbanismo e data de realização da entrevista.

Entrevista 01: feminino, 56 anos, funcionária pública na Empresa Municipal de Obras e Urbanização de Aracaju, proprietária de escritório de arquitetura e urbanismo, outubro de 2017.

Entrevista 02: masculino, 63 anos, aposentado e proprietário de escritório de arquitetura e urbanismo, outubro de 2017.

Entrevista 03: masculino, 61 anos, aposentado e proprietário de escritório de arquitetura e urbanismo, outubro de 2017.

Entrevista 04: masculino, 36 anos, funcionário público na Empresa Municipal de Obras e Urbanização de Aracaju, novembro de 2017.

Entrevista 05: masculino, 42 anos, superintendente do Instituto Banese, proprietário de escritório de arquitetura e urbanismo, professor universitário na UNIT, novembro de 2017.

Entrevista 06: feminino, 64 anos, presidente do CAU/SE, professora universitária na UFS, novembro de 2017.

Entrevista 07: feminino, 37 anos, autônoma, novembro de 2017.

Entrevista 08: masculino, 39 anos, proprietário de escritório de arquitetura e urbanismo, conselheiro do CAU/SE, novembro de 2017.

Entrevista 09: masculino, 66 anos, proprietário de escritório de arquitetura e urbanismo, novembro de 2017.

Entrevista 10: feminino, 41 anos, funcionária pública em prefeitura do interior do Estado de Sergipe, proprietária de escritório de arquitetura e urbanismo, setembro de 2017.

Entrevista 11: masculino, 45 anos, funcionário público do Governo do Estado de Sergipe, proprietário de escritório de arquitetura e urbanismo, outubro de 2017.

Entrevista 12: masculino, 53 anos, proprietário de escritório de arquitetura e urbanismo, setembro de 2017.

Entrevista 13: masculino, 65 anos, aposentado, outubro de 2017.

Entrevista 14: masculino, 60 anos, funcionário público em prefeitura, setembro de 2017. 


\title{
"Meu Deus! Meu Deus! Está Extinta a Escravidão?”: o Imaginário Político Brasileiro
}

\author{
Glória Diógenes* \\ Paulo Henrique Martins* *
}

\section{RESUMO}

O artigo tem como objetivo identificar signos da transgressão do imaginário político brasileiro em suas conexões com a dimensão da festa. O texto tem por base o desfile da Escola de Samba Paraíso do Tuiuti, do Rio de Janeiro, no carnaval de 2018. Consideramos que o desfile da Tuiuti produziu o que pode ser denominado de um "teatro do patético”, coreografando, no espaço da Sapucaí, imagens — que muitas vezes não são nítidas — da situação política do país. Parte-se do pressuposto de que a formação de esferas públicas participativas no Brasil nem sempre estiveram ligadas ao mundo do trabalho, às mobilizações sindicais e aos partidos supostamente comprometidos com práticas democráticas. A festa produz, no plano das ações instituintes, dispositivos que parecem colidir com a ordem social, traduzindo outros signos de produção de uma cultura política contestatória.

Palavras-chave: Escola de Samba Tuiuti. Festa. Imaginário político e democrático.

* Glória Diógenes é antropóloga da Universidade Federal do Ceará (UFC-Brasil) e pesquisadora do CNPq.

* * Paulo Henrique Martins é sociólogo da Universidade Federal de Pernambuco (UFPE-Brasil) e pesquisador do CNPq. 


\begin{abstract}
"MY GOD! MY GOD! IS SLAVERY EXTINCT? “: THE BRAZILIAN POLITICAL IMAGINARY
\end{abstract}

The article aims to identify signs of the transgression of the Brazilian political imaginary, regarding the dimension of celebratory festivities. The text is based on the 2018 carnival parade of the Samba school Paraíso do Tuiuti, from Rio de Janeiro. We consider that Tuiuti's parade at Sambadrome Marquês de Sapucaí produced what can be called a "theater of the pathetic", conveying images of the country's political situation that were not always clear. It is assumed that the formation of participatory public spheres in Brazil has not always been linked to the world of work, trade union mobilizations and political parties supposedly committed to democratic practices. The festivities produce, at the level of instituting actions, devices that seem to clash with the social order, translating other signs of production of a contestatory political culture.

Keywords: Tuiuti samba school; celebration; political and democratic imaginary.

\title{
Festa, poder e resistência
}

O enredo do desfile da Escola de Samba Paraíso do Tuiuti, no Rio de Janeiro, neste ano de 2018, foi marcado por uma contundente crítica social e cujo título do samba-enredo foi "Meu Deus! Meu Deus! Está extinta a escravidão?”1. Ao denunciar cenas patéticas² da atual conjuntura brasi-

1 O samba da escola é de autoria dos compositores Moacyr Luz, Cláudio Russo, Dona Zezé, Aníbal e Jurandir. Segundo fontes consultadas, "As primeiras negociações para a criação da Paraíso do Tuiuti datam de 1952. Porém, a fundação da escola foi concretizada apenas em 1954, após a extinção da Unidos do Tuiuti. À época, a Paraíso da Baianas também enfrentava um declínio. Os moradores do morro, sem condições financeiras para acompanhar o carnaval das escolas de samba, preferiam participar de blocos carnavalescos como o Bloco dos Brotinhos, também do Tuiuti. Foi então que um grupo de sambistas se reuniu, entre eles Nélson Forró e Júlio Matos, e resolveu terminar com o bloco e, também, com a Paraíso das Baianas e criar uma nova escola de samba. O Grêmio Recreativo Escola de Samba Paraíso do Tuiuti foi fundado em 5 de abril de 1954 por Augusto Pirulito, Joaquim, Araquem, Armando, Murilo Aragão, Zeba, Orlando, José Orelhinha, Alcides Fornalha, Pedro Feneno, Duca, Zequinha, Álvaro, Conceição e Felícia”. Disponível em: < https://pt.wikipedia.org/ wiki/Para\%C3\%ADso do Tuiuti>. Consultado em: 26 mar. 2018.

2 Utilizamos a terminologia "patético" no sentido empregado por Aby Warburg — ver obra Histórias de fantasmas para gente grande (2015, p. 11), na qual o autor indica ser a "fórmula do pathos" uma espécie de linguagem gestual, um tipo de "forma da memória social coletiva" — e rediscutido por Etienne Samain (2012, p. 56) no livro "O que pensam as imagens?". Patético emerge do conceito de Pathosformel como sendo aquilo que condensa danças de medo e terror, desejo, paixão, sedução, sofrimento, crença, fé, segundo ele, imagens que assumem formas meio fantasmáticas, mapas que atuam como "uma enciclopédia de movimentos em constante andança no tempo" (p. 56). 
leira ${ }^{3}$ e de seus processos históricos, o desfile gerou entusiasmos e perplexidades. Por meio da festa, daquilo que poderia ser situado no âmbito do lazer e da brincadeira, a Tuiuti fez eclodir um texto eloquente sobre a atual política nacional. O texto carnavalesco teve êxito em fazer figurar, com imagens irônicas, comportamentos ambíguos de setores das classes médias, empresários e políticos, tendo ainda como destaque o atual presidente Michel Temer - fantasiado, na ocasião, de vampiro neoliberal ${ }^{4}$.

O desfile da Tuiuti produziu um teatro do patético, "coreografando” imagens embaraçosas ${ }^{5}$ da situação política do país na Sapucaí. A referida matéria da revista Carta Capital sobre o evento, revela dados contundentes que justificam o impacto do tema da escravidão e de sua atualidade. Nesta direção, os números da realidade social brasileira ratificam as denúncias apresentadas pelo enredo da escola vice-campeã do carnaval carioca (e também confirmada no desfile da Mangueira). Os dados apresentados pela Carta Capital são incontestáveis: 64\% da nossa população carcerária é composta por pessoas negras. O genocídio da população negra, atestado pelas estatísticas do Atlas da Violência de $2017^{6}$, lançado pelo Instituto de Pesquisa Econômica Aplicada (Ipea), reverbera no fato de que a cada 100 pessoas assassinadas no Brasil 71 são negras. Mais: enquanto a mortalidade de não-negras (brancas, amarelas e indígenas) caiu 7,4\% entre 2005 e 2015, entre as mulheres negras o índice subiu para assustadores $22 \%$.

Naturalmente, o caráter crítico da "encenação” do enredo da Escola provocou um efeito coletivo surpresa, na medida em que mexeu com estruturas

3 Em 31 de agosto de 2016, o Senado Federal aprovou o impeachment de Dilma Rousseff, presidente eleita em 2014, constando 61 votos favoráveis e 20 contrários. Segundo a imprensa, "a presidente afastada foi condenada sob a acusação de ter cometido crimes de responsabilidade fiscal nas chamadas 'pedaladas fiscais', no Plano Safra, e nos decretos que geraram gastos sem autorização do Congresso Nacional, mas não foi punida com a inabilitação para funções públicas”. Disponível em: http://g1.globo.com/politica/processode-impeachment-de-dilma/noticia/2016/08/senado-aprova-impeachment-dilma-perdemandato-e-temer-assume.html. Consultado em: 26 mar. 2018. Assumiu em seu lugar o vicepresidente Michel Temer, confirmando a impressão de grande parte da opinião pública de um golpe político. Contra este processo de desestabilização institucional, surgiram intensos movimentos coletivos, nas ruas e nas redes, cujo o mote foi e continua sendo: "Fora Temer".

4 O vampiro foi representado pelo professor de história Léo Morais no último carro da escola, o navio "neo tumbeiro". Disponível em: https:/g1.globo.com/rj/rio-de-janeiro/ carnaval/2018/noticia/desfile-da-paraiso-do-tuiuti-tem-presidente-vampiro-de-destaque-eala-de-manifestantes-fantoches.ghtml. Consultado em: 26 mar. 2018.

5 Disponível em: http://justificando.cartacapital.com.br/2018/02/19/desfile-da-paraiso-datuiuti-expos-os-limites-de-uma-liberdade-que-nao-existe/. Consultado em: 29 mar. 2018.

6 Disponível em: http://www.ipea.gov.br/atlasviolencia/download/2/2017. Consultado em: 29 mar. 2018. 
do imaginário arcaico brasileiro. As reações contrárias se explicam pelas resistências das elites de confrontar os perigos da fratura social e histórica. Por isso, tais respostas visam desfigurar a carnavalização da política, como se devesse ser interditado às agremiações produzir desfiles que trouxessem como enredo central as chagas sociais do Brasil. A redução do carnaval ao pastiche cultural revela o caráter conservador de reações que buscam reduzir a festa a objeto de consumo, desconhecendo o valor desta na organização política da esfera pública.

O evento provocado pela Tuiuti convida a crítica sociológico-antropológica a deslocar sua perspectiva de interpretação para outro lugar que permita entender como - apesar da rejeição do autoritarismo à participação social - tem ocorrido, de fato, a emergência de esferas públicas democráticas nos centros urbanos ao longo dos séculos XX e XXI. Esse deslocamento implica em considerar que as possibilidades de formação de esferas públicas participativas, no Brasil, nem sempre estiveram ligadas ao mundo do trabalho, às mobilizações sindicais e aos partidos supostamente comprometidos com práticas democráticas.

Nesse tipo de sociedade pós-colonial, há outros lugares de produção da esfera pública ligados à dimensão estética e lúdica e que tornam o entendimento das lutas políticas, sindicais e associativas um jogo complexo de emoções e estratégias. Assim, a organização do público está relacionada, frequentemente, a táticas de resistências culturais e étnicas contra a imposição da crença na existência de uma única cultura nacional, inspirada nos valores das elites oligárquicas.

Tais deslocamentos, tal qual assinala Arjun Appadurai (2004, p. 48), têm a imaginação como prática social. Eles são decisivos para a sobrevivência de dispositivos de produção do pluralismo nacional e de diálogos mobilizadores de signos culturais populares e étnicos, ritualizando as memórias, as tradições e a criação e recriação coletiva do mundo urbano. A atual conjuntura política favorece, logo, a recodificação do público urbano, de vivências comunitárias construídas entre o campo e a cidade, entre religiosidades e tradições diversas. Onde faltaram as condições para uma cultura da dignidade do trabalho emergem, nesse quadro de recriação das instituições sociais, modos de fabulação e organização de práticas sociais fraternas centrados nos usos expressivos dos corpos, nas artimanhas da imaginação, na ocupação urbana e na invenção da cidade. 
Frente a esse contexto de "golpe”, as estratégias populares de construção dos espaços de emancipação política passam, então, não apenas pelas lutas por melhorias no trabalho, mas, igualmente, pelo desenvolvimento do que Appadurai (2004) vai denominar de “mundos imaginados”. Na visão do referido autor, "a imaginação hoje é um palco para a ação e não apenas para a evasão” (2004, p. 20). A prática da imaginação permite, assim, deslocar nas ruas as divisões de classes e etnias, propiciando inusitadas conexões simbólicas nas esferas cultural, artística e política.

As escolas de samba em geral, e no caso mais específico do desfile da Tuiuti, contribuem para o entendimento de que as rebeldias dos grupos comumente alijados das decisões do poder apontam para outros lugares de invenção da política e que não se reduzem às lutas sindicais e arenas usuais de luta social. As rebeldias no âmbito das práticas culturais ativam "linhas de fuga” (DELEUZE; GUATTARI, 1995) no imaginário estético, sinalizando outro modo de se construir a esfera pública. Liberam emoções que comumente são reprimidas pelas regras e costumes que balizam os pactos e códigos da vida social.

Estas rebeldias apontam para vias de desconstrução do discurso oficial autoritário e disciplinar, que propõe uma política cultural de consumo utilitarista a qual desvaloriza o tempo da brincadeira solidária e descontraída. Contra essa orientação de uniformização cultural, surgem reações e novas construções imaginárias, que sublimam a dor da violência, as exclusões e as memórias das saudades para promover a alquimia da alegria e da irreverência mundana. Na passagem da dor para o humor, germinam os "húmus" das políticas de resistência. Esse é outro modo de se entender os fundamentos do bem público e do bem comum na luta contra as sombras da escravidão, devidamente assinaladas por Jessé Souza (2017), importante inspirador intelectual do desfile da Tuiuti.

Distanciando-nos das turbulências conjunturais provocadas pelo "golpe”, entendemos que o desfile da Tuiuti revela um acontecimento exemplar para orientar uma reflexão crítica sobre os caminhos próprios de manifestação da esfera pública e das vivências das práticas democráticas no Brasil. A natureza da política brasileira é um evento singular que não pode ser comparado a outros exemplos históricos, como aquele da formação do público democrático e popular nos Estados Unidos, entre os séculos XVIII e XIX, e que foi marcado por intensa participação dos indivíduos na organização da 
vida local - conforme retratou A. de Tocqueville (2005) no seu clássico $A$ democracia na América. Ali, o pacto republicano nasceu de baixo para cima e a organização do Estado nacional e do sistema federativo foi resultado, nos seus primórdios, de imensas negociações entre os poderes central e local. Diferentemente, sociedades pós-coloniais como a brasileira, seguindo o modelo patrimonialista ibérico — que privilegia as elites oligárquicas, econômicas, políticas e burocráticas na organização vertical e autoritária da vida social —, sempre foram avessas a mobilizações populares independentes e autônomas, por verem nesta possibilidade uma ameaça ao poder oligárquico centralizado. É importante, portanto, introduzir algumas considerações sobre a natureza do pacto republicano no Brasil, para se entender como a emergência do público se realizou nas contradições da modernização e da conservação do poder.

\section{A república do patético}

Há de se convir que o capitalismo colonial, de modo geral, tem características diferentes de um capitalismo inspirado por uma ética protestante da realização da espiritualidade pelo trabalho produtivo e pela poupança como base do processo civilizacional coletivo, como vemos sugerido por M. Weber (2004). Nessas sociedades de base patrimonial, a organização do poder condiciona a cultura mercantilista do lucro aos hábitos e valores aristocráticos relacionados com o imaginário ibérico (MARTINS, 2002).

Além do mais, é de se ressaltar que a tradição patrimonialista de uma cultura da ostentação e do ócio sem criatividade é reforçada pelo caráter especulativo do capitalismo financeiro internacionalizado. A velha e a nova cultura oligárquica especulativa se encontram nas fronteiras abismais da modernidade ocidental.

Contudo, nos interstícios do sistema dominante — ali onde o imaginário instituído e decadente é confrontado pela nova criação, pelo instituinte não antes imaginado (CASTORIADIS, 1982) —, ressurgem movimentos sócio-históricos inéditos. Estes acontecem fora das esferas tradicionais da política, produzindo reversões de expectativas, revitalizando a participação popular e germinando paisagens múltiplas de construção de direitos, que instauram uma cultura celebratória e criativa. Nesse sentido, vale lembrar que, durante a dominada década “dos direitos” no Brasil (os anos de 1980), 
foram fomentadas "fora" do Estado e do parlamento múltiplas instâncias de lutas sociais, as quais não se referiam somente ao mundo sóbrio do trabalho produtivo, mas, igualmente, às mobilizações estéticas expressas nos processos de renovação da arte e da cultura nas ruas ${ }^{7}$.

Esse encontro entre novas e velhas culturas oligárquicas é o contexto de aparecimento da república do patético, que sabota a moral clássica da república liberal, fundada na liberdade individualista e utilitarista, ao deslocar o imaginário político e cultural, revertendo a relação entre tradição e modernidade para enclausurar esta última na primeira. Nas origens da república do patético, o termo latino res publica, coisa pública, tem uma conotação alienígena. Ele não se encaixa facilmente na natureza do sistema de poder "republicano" criado no Brasil com o fim do regime imperial, no final do século XIX - um regime republicano, diga-se, presente na sua formalização jurídica, mas oligárquico e autoritário no seu modo prático de existir. Nas ruas desfilavam não as massas organizadas, mas senhores de sapatos lustrados e cavaleiros uniformizados.

Por ocasião da fundação da “República Velha”, inaugura-se o que, no corpo desse artigo, estamos denominando república do patético. Esta nasceu de um pacto entre elites oligárquicas, econômicas, religiosas e militares, no contexto da nova ordem econômica internacional e sem considerar os anseios das multidões, que, para a classe dominante, eram apenas grupos étnicos movidos por reclamações. A corrente abolicionista, tal qual aquela representada por Joaquim Nabuco (2000), entendia ser a escravidão um impedimento para o desenvolvimento do mercado de trabalho e para as políticas industrialistas e comerciais. Mas, mesmo entre os "liberais" da república, o tema da liberdade individual — fundamental para se pensar um sistema republicano e democrático - era objeto de muitas resistências culturais e étnicas, resultantes da tradição autoritária. Como explica José Murilo de Carvalho, o argumento da liberdade individual como direito inalienável era visto com muitas restrições pelas elites, que, influenciadas pela tradição ibérica, eram

7 Na apresentação do livro Brasil urbano - Cenários da ordem e da desordem, A. C. Torres Ribeiro (1993, p. 11) aponta que os anos de 1980 significaram "a emergência de um complexo tecido social e político no país. Velhas e novas tendências encontram os rumos de sua articulação desafiando análises realizadas e exigindo das Ciências Sociais intenso esforço de renovação teórico-conceitual e empenho no desenvolvimento de pesquisa empírica”. Na nossa compreensão, esse justo esclarecimento conceitual da autora deve ser complementado pelo entendimento que a ordem e a desordem daquele período produziram igualmente novas articulações no imaginário estético. 
alheias ao iluminismo libertário e favoráveis ao entendimento religioso e católico da vida política, segundo o qual era mais importante "a supremacia do todo sobre as partes, a cooperação sobre o conflito e a hierarquia sobre a igualdade" (CARVALHO, 2002, p. 51) ${ }^{8}$.

As mobilizações sociais e culturais na história republicana brasileira durante os séculos XX e XXI apresentam diferenças em relação ao surgimento de esferas públicas civis e comunitárias em sociedades liberais modernas, na medida em que a dominação oligárquica e escravista incluiu o constitucionalismo liberal apenas como retórica. No Brasil, as lutas pela democracia como participação da multidão organizada ocorreram nas franjas do sistema político e por iniciativa de setores populares ${ }^{9}$ e da classe média articulados pelos mundos do trabalho e da cultura. Tais lutas eram vistas com resistências e suspeições pelas elites oligárquicas. Estas temiam que as mobilizações sociais se constituíssem em ameaça efetiva contra a grande propriedade e contra o sistema estatal autoritário e centralizado. Daí se entende a célebre frase atribuída a Washington Luís, presidente da república, em 1926: "A questão social é um caso de polícia”.

A falta de perspectivas de maior participação social nas decisões políticas e governamentais favoreceu, por outro lado, o uso da imaginação política coletiva nas expressões lúdicas, festas, danças e cantos. A rua, a praça e a ponte se tornaram o palco de articulações de indivíduos de classes, religiosidades e nacionalidades diferentes em torno da formação do espaço público compartilhado. A gestualidade corporal e os ritmos ocuparam o lugar da gramática política permitida pelas crenças religiosas e elitistas. Gargalhadas, escárnio, exibicionismos de toda ordem, irreverências se manifestaram como armas de contestação. Exemplo mais nítido deste processo de transfiguração da arte cênica e do lúdico em ação política é magistralmente representado pelo frevo de rua, que surgiu no final do século XIX, estetizando como manifestação coletiva supraracial as heranças da capoeira - tradição afro-brasileira que mistura esporte, arte marcial, música e cultura popular.

8 Tais observações são relevantes para se entender que os discursos colonialistas do poder se apropriam de inovações jurídicas e institucionais a fim de atualizar o conservadorismo, sob pressão das mutações do capitalismo colonial. Mas tal atualização não foi flexível o bastante para acolher a luta real pela formação de esferas públicas participativas nos planos locais no momento de extinção da ordem escravagista e de criação de um modelo de sociedade baseado no trabalho livre e na liberdade da cidadania democrática.

9 Sobre a emergência dos movimentos sociais na década de 1980, ver o texto de Glória Diógenes intitulado "Modernidade, identidade e movimentos sociais", publicado no livro Brasil urbano - Cenários da ordem e da desordem, Rio de Janeiro, 1993. 
Lembra a pesquisadora Rita de Castro Barbosa de Araújo (1997, p. 205) que as elites recifenses pretendiam estilizar o carnaval e dominar as ruas a partir dos usos de máscaras e verves elaboradas e inspiradas nos carnavais de Veneza e de Paris, acessíveis apenas aos mais abastados.

Contrariada, a multidão que deveria ficar nas calçadas apenas assistindo aos carros alegóricos se insurgia, guiada por capoeiras, pelos "populares”, muitas vezes considerados desordeiros e valentões, que puxavam as bandas de músicas e os estandartes. As elites foram, assim, praticamente obrigadas a aceitar as manifestações populares como o frevo, o samba, as danças de roda e outras, que passaram a funcionar como dispositivos de integração de raças e classes. Onde faltava o espaço para a negociação política por partidos organizados, prosperou o espaço do divertimento, da celebração, da irreverência e da alegria, forjando outro modo de fazer política por meio da resistência estética.

C. Soares (1998) assinala que, até por volta do século XIX, operava aquilo que E. Hobsbawm (1982, p. 292-293) designou de "divertimento dos pobres”, em que muitos desses atores traziam o corpo como espetáculo.

Traziam o corpo como espetáculo. Invertiam a ordem das coisas. Andavam com as mãos, lançavam-se no espaço, contorciam-se e encaixavam-se em potes, em cestos, imitavam bichos, vozes, produziam sons com as mais diferentes partes do corpo, cuspiam fogo, vertiam líquidos inesperados, gargalhavam, viviam em grupos. Opunham-se assim ao novo cânone do corpo acabado, perfeito, limpo e isolado que a ciência construiria, de vida fixa e disciplinada que a ordem exigia (SOARES, 1998, p. 25).

O corpo, em situações de repressão e silêncio, parece atuar como suporte e código de outras possibilidades de imaginação da vida. Nesse clima de multiculturalismo colonial, o surgimento do regime republicano emoldurou o espaço da política de duas maneiras: por um lado, restringindo a participação da população no processo eleitoral; por outro, criando as brechas pelas quais as energias criativas populares se libertavam, ludicamente, na produção da vida coletiva.

As esferas públicas não nasceram no Brasil, prioritariamente, nos espaços do trabalho produtivo de indivíduos e familiares, os quais tanto valor tinham para as comunidades protestantes na Europa e nos Estados Unidos. No Brasil, tais esferas públicas surgem nas ruas, praças, ou mesmo nas intimidades das casas onde os blocos de músicos, dançarinos(as) e cantores(as) se revezavam 
nos momentos de preparação das festas públicas, cimentando, pelos corpos e cânticos, a unidade do popular. Política e festa continuam a caminhar juntas nos carnavais, páscoas, são joões e outras celebrações — organizando politicamente a mestiçagem, o sincretismo religioso, o pluralismo musical e de ritmos.

A reação dos críticos culturais, da mídia e de setores das elites com relação ao desfile da Escola de Samba Paraíso do Tuiuti apenas parece revelar o profundo desconhecimento sobre o caráter estético e mágico das festas de rua no Brasil, bem como acerca de seu potencial político como emblema rebelde e de contestação da república do patético. No fundo, os estranhamentos revelam resistências das elites no que diz respeito à emergência do popular como expressão de rebeldia, de descontentamento e de impaciência com as injustiças social, étnica e racial.

Nessa perspectiva, o atual sobressalto da mídia e dos setores conservadores em relação à Tuiuti expressa o mesmo sentimento de desgosto das elites da "República Velha" no tocante à presença de grupos de populares nas ruas, as quais elas consideravam dever constituir espaços destinados ao desfile dos ricos. Contra essas atitudes discriminatórias, as manifestações das escolas de samba reavivam os sentidos rebeldes dos setores populares pelas escolas de frevo, de passistas inflamados pelas tradições dos quilombos. Apontam, desse modo, a irreverência e a imaginação como fomentadores de um outro lugar de produção do social, do cultural, do artístico e do viver coletivo.

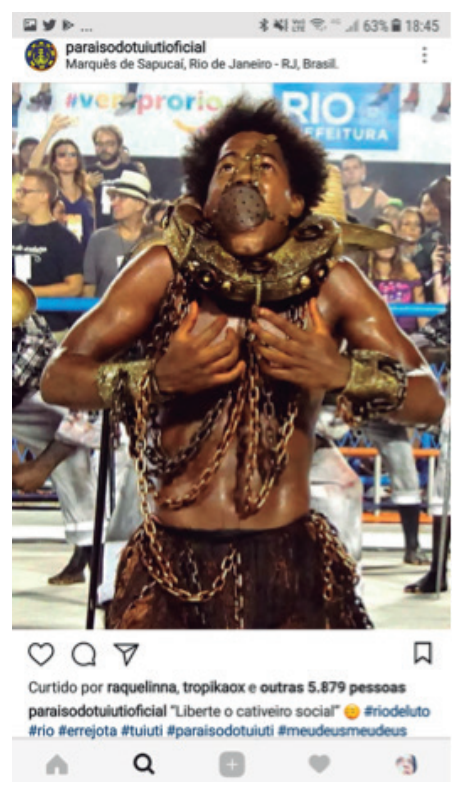




\section{Tuiuti: entre as memórias da escravidão e as sentinelas da libertação}

Essa imagem da Paraíso do Tuiuti, publicada em 15 de março de 2018 no Instagram $^{10}$, foi uma das mais partilhadas nas redes sociais, ao lado daquela outra que destaca o "vampiro neoliberal”. A Escola de Samba retomou, neste ano, a temática da servidão, fazendo uma reflexão acerca dos 130 anos da Lei Áurea, que extinguiu a escravidão no Brasil.

A comissão de frente compareceu com um "grito de liberdade", trazendo figurantes que interpretavam escravos negros sendo açoitados por um capataz. O carro abre-alas, intitulado "Quilombo Tuiuti”, enalteceu cenas de tribos africanas molduradas por animais como rinocerontes, representando a força e a determinação. Já outro carro reavivou a imagem de um navio negreiro atravessando correntes marítimas. O último carro teve como destaque um vampiro com uma faixa presidencial, fazendo uma alusão a Michel Temer. Outra ala evidenciou o trabalho informal, com participantes fantasiados de ambulantes, e uma terceira exaltou os "guerreiros da CLT", com operários empunhando uma gigantesca carteira de trabalho.

Desse modo, o desfile da Escola Paraíso do Tuiuti acabou por condensar, de forma alegórica, um conjunto de imagens metamórficas que, para Jacques Rancière (2011, p. 36), sugere "um mostruário da presença que permite identificar as dissemelhanças da arte nos jogos da arqui-semelhança”. Com seus carros e alas, o desfile condensou tanto um efeito de verossimilhança com fatos da história política brasileira - um "mostruário de sua presença" — quanto mobilizou um jogo de dissemelhança, alternando e conectando, ao mesmo tempo, ilusão e veracidade, real e imaginário, festa e política, entre as memórias da escravidão e os sonhos da libertação.

A historiografia brasileira é rica de estudos voltados para explicar a importância do regime escravista na organização do nosso sistema cultural, social e político. Jacob Gorender (1978) propôs a existência de um modo de produção escravagista como sendo peculiar na formação histórica brasileira. Mais recentemente, Luis Felipe de Alencastro (2000), no seu Trato dos

10 Instagram é uma rede social online de partilha de fotos e vídeos entre seus usuários, que possibilita aplicar filtros digitais e compartilhá-los em uma multiplicidade de serviços de redes sociais, lançada em outubro de 2010, cujo proprietário, atualmente, é uma outra rede social, o Facebook. 
viventes, busca ressaltar a construção do império ultramarino português a partir das redes comerciais no Atlântico Sul, notadamente as do tráfico negreiro. Por sua vez, Jessé Souza (2017) costuma afirmar que a escravidão é o principal pilar da nossa formação histórica, e não os desvios éticos, comuns a todos os povos. Enfim, nas últimas décadas, diversos historiadores buscaram consolidar a escravidão como tema central para esclarecer o caráter conservador e autoritário de nossa formação social e cultural.

Matéria jornalística ${ }^{11}$ assinada por Miguel Martins sinaliza que o tema da escravidão se traduz como um dos principais pilares da formação histórica brasileira, confirmando o que vem sendo destacado pela crítica acadêmica (SOUZA, 2017). Entrevista concedida pelo carnavalesco da Escola, Jack Vasconcelos $^{12}$, formado em Belas Artes, reforça o ponto de vista de Miguel Martins, ao considerar que o objetivo do desfile foi o de tornar "as pessoas mais espertas ao que chega de informação para elas", colocando em xeque o que é comumente repassado pela mídia:

[...] o desfile desse ano teve seu conceito no interior da cultura brasileira, na sua raiz. Se as pessoas conseguiram perceber isso de alguma forma, diz ele, valeu a pena. Dessa maneira, Jack aponta que o carnaval sempre foi o espaço para esse tipo de ideia, para as pessoas colocarem para fora o que sentem, aquilo que querem gritar. $^{13}$

Em contraposição à onda de entusiasmo que mobilizou o Brasil com a difusão das imagens da Tuiuti na Sapucaí, surgiram reações conservadoras, como é o caso do Movimento Brasil Livre (MBL) ${ }^{14}$, que procurou descaracte-

11 Disponível em: https://www.cartacapital.com.br/cultura/tuiuti-e-beija-flor-entre-o-pais-daexploracao-e-o-da corrupcao. Consultado em: 29 mar. 2018.

12 Disponível em: https://odia.ig.com.br/_conteudo/2018/02/diversao/carnaval/5513526carnavalesco-jack-vascon celos--tem-que-se-posicionar.html. Consultado em: 29 mar. 2018. Outra fonte indica que a ligação de Jack com a festa "vem da infância, quando a mãe, portuguesa, desfilava na ala das baianas da Estácio, tradicional escola do bairro onde ele cresceu e mora até hoje. Na adolescência, ele se ofereceu para trabalhar no barracão da escola, onde são confeccionadas alegorias e fantasias. Ganhou prática e virou aderecista, com passagens por algumas agremiações na função. Seu passo mais ousado ocorreu na década passada. Assinou como carnavalesco desfiles do Grupo de Acesso, a segunda divisão do samba, sem, no entanto, conseguir ascender para a elite”. Ver em: https://epoca.globo.com/sociedade/noticia/2018/02/ leonardo-morais-o-vampiro-neoliberalista-da-tuiuti.html. Consultado em: 28 mar. 2018.

13 Disponível em: https:/odia.ig.com.br/_conteudo/2018/02/diversao/carnaval/5513526carnavalesco-jack-vasconcelos--tem-que-se-posicionar.html. Consultado em: 29 mar. 2018)

14 O Movimento Brasil Livre (MBL), criado em novembro de 2014, em São Paulo, apoiou o impeachment da presidente Dilma Rousseff. Ver em: http://mbl.org.br/. Consultado em: 29 mar. 2018. 
rizar o sentido rebelde do desfile, buscando criminalizar sua expressão estética $^{15}$. As correntes conservadoras ${ }^{16}$ buscaram depreciar o desfile da Tuiuti, acusando a Escola de propor uma "agenda militante". Exemplo deste tipo de prática reacionária é revelada pela plataforma denominada Huffpost ${ }^{17}$, que, em matéria sobre o desfile, criticou as referências à escravidão com o seguinte teor:

A agenda militante começa no próprio título do enredo: insinua-se que a fraca reforma trabalhista é a volta da escravidão. O desrespeito com a memória dos verdadeiros escravos, cujo sofrimento é banalizado ao ser nivelado com parcelar férias ou criar empregos de baixa carga horária, é gritante e sem escrúpulos.

No artigo "O que a esquerda tem a aprender com o desfile da Tuiuti"18, Jessé de Souza reforça a importância da retomada do tema da escravidão para se conhecer o imaginário político brasileiro ${ }^{19}$. De acordo com ele, "após o golpe de 2016”,

A escola conseguiu retumbante sucesso ao contar a história da escravidão nos nossos dias produzindo um efeito de conhecimento acerca tanto da dimensão histórica quanto do esclarecimento dos mecanismos do momento político atual simplesmente sem paralelo desde o golpe de 2016.

15 Disponível em: https://www.revistaforum.com.br/mbl-apanha-nas-redes-depois-de-postcontra-o-desfile-da-paraiso-do-tuiuti/. Consultado em: 29 mar. 2018. "Com o propósito de desmoralizar o desfile da Tuiuti, o movimento havia publicado que o carnavalesco responsável pela apresentação, Jack Vasconcelos, 'publicou mensagens de ódio'. As tais mensagens seriam posts contra Temer, a reforma trabalhista e demais ataques ao governo golpista. No entanto, o ponto alto da vergonha do MBL foi o compartilhamento da notícia do site Ceticismo Político cujo título é "A Tuiuti fingiu protestar contra a escravidão, mas defende as leis escravagistas da extrema esquerda”. Depois de uma série de críticas, o link foi apagado do site, mas na descrição do post na página do MBL chegam a dizer que "toda escravidão no capitalismo, na história moderna, foi pelo menos ajeitada pela extrema esquerda”. A publicação é do Esquerda Diário.

16 Como é o caso de Luiz Guilherme Medeiros, diretor do Instituto Liberal do Centro-Oeste. Ver em: https://www.huffpostbrasil.com/luiz-guilherme-medeiros/a-paraiso-do-tuiutidesfilou-os-erros-do-fora-temer_a_23362865/. Consultado em: 29 mar. 2018.

17 Disponível em: https://www.huffpostbrasil.com/luiz-guilherme-medeiros/a-paraiso-dotuiuti-desfilou-os-erros-do-fora-temer_a_23362865/. Consultado em: 29 mar. 2018.

18 Disponível em: https://www.cartacapital.com.br/politica/o-que-a-esquerda-tem-a-aprendercom-o-desfile-da-tuiuti. Consultado em: 30 mar. 2018.

19 Jessé de Souza (2017), A elite do atraso: da escravidão à Lava Jato. São Paulo: Leya, 2017. 
Souza $^{20}$ sugere nessa matéria da Carta Capital que há linhas de continuidade entre a escravidão do século XIX com a dos nossos dias, "apenas travestindo-se, atualmente, de providenciais 'máscaras modernas".

O pintado e decantado quadro de horror da atual política brasileira traz para o centro do debate apreciações críticas que se reportam a uma possível morte ou refluxo das conquistas democráticas no Brasil. Quais esferas de atuação e participação militantes estariam sendo canalizadas pelo desfile da Tuiuti? De que modo tais ações expressam o inconformismo e a revolta de setores expressivos da população brasileira com a estrutura social fragmentada e insegura?

\section{Imaginário instituinte: a política toma conta da Sapucaí}

Como já abordado no primeiro tópico deste artigo, observam-se mutações complexas nos modos de exercício da política no Brasil. Os movimentos sociais e as lutas sindicais que culminaram na organização da Central Única dos Trabalhadores (CUT) e na criação do Partido dos Trabalhadores (PT), desde os anos de 1980, têm atravessado estremecimentos que põem em xeque grande parte das conquistas democráticas populares. Mas, em contraposição ao atual contexto do que poderíamos denominar de retração democrática provocada pelo "Golpe”, verificam-se algumas reações inusitadas, como no caso emblemático da Tuiuti, mobilizando dispositivos outros de socialidades e de produção de subjetividades.

Na perspectiva de Suely Rolnik e Felix Guattari (2010, p. 34), “as mutações de subjetividade não operam no registro das ideologias, mas no próprio coração dos indivíduos, em sua maneira de perceber o mundo, de se articular com o tecido urbano, com os processos maquínicos do trabalho". A questão central dos autores está em pensar os movimentos das minorias e suas práticas de resistências para além das máquinas sociais e de seus organismos de controle. Segundo eles, criam-se, ali, nas franjas, nas relações micropolíticas, práticas culturais que operam e dinamizam "novos agenciamentos coletivos de enunciação" (p. 34).

A construção da subjetividade política migra para outros lugares, produzindo novas práticas sociais, instaurando micropolíticas para além do modelo

20 Disponível em: https://www.cartacapital.com.br/politica/o-que-a-esquerda-tem-a-aprendercom-o-desfile-da-tuiuti. 
clássico de Estado e Parlamento. São lugares que revelam não só a revolta e o inconformismo, mas também o desconforto e a humilhação daqueles setores da sociedade que se sentem destituídos. São espaços de ressignificação da vida e da morte e em que se forjam experiências extremas nas quais a reinvenção da política atravessa fronteiras e emerge na textura de peles, danças, contravenções, revoltas - produzindo agenciamentos diversos daqueles que regulam e operam a "máquina social”, como diriam Guattari e Rolnik (2010).

Na denominada "década de direitos", aquela dos anos de 1980, vale destacar a emergência dos movimentos sociais, os quais se revelavam como um drible ao Estado-fortaleza, que deve ser entendido, segundo C. N. Coutinho (1994), como aquele representativo do regime de poder criado com o golpe de 1964. Este autor, na obra Marxismo e política: A dualidade de poderes e outros ensaios (1994), inspirando-se em Gramsci, assinala que o processo de "fechamento" do Estado dentro da arena do governo e do parlamento, diante de dinâmicas de "socialização da política”, acaba por construir distâncias e linhas demarcadas entre o que é "sociedade” e o que é "política”.

Tais movimentos faziam surgir uma diversidade de lutas cotidianas, o que motivou alguns autores (SCHERER-WARREN; KRISCHKE, 1987) a indagarem se o recrudescimento dos mesmos sinalizaria uma "revolução no cotidiano". Podemos indicar que estas são lutas em que "sobreviver é, por conseguinte, fugir ou romper o anonimato [...]” (CERTEAU, 1995, p. 92). Fora do campo das relações entre capital e trabalho que marcaram os movimentos sociais e as lutas sindicais e partidárias, irrompem mobilizações que mexem com as expressões psicológicas, morais e estéticas coletivas. As mais recentes delas atuam como "linhas de fuga" (DELEUZE; GUATTARI, 1997) de um cotidiano inseguro, massacrante, adornando como centelhas luminosas as fissuras do trágico. Didi-Huberman, no livro Sobrevivência dos vaga-lumes (2011, p. 27), retoma a indagação de Pasolini sobre as dificuldades dos intelectuais italianos de perceberem o alcance trágico do fascismo. Dizia o cineasta que "os intelectuais mais avançados e os mais críticos não perceberam que os vaga-lumes estão desaparecendo” (2011, p. 27). E, concluía, o verdadeiro fascismo é aquele que tem como alvo "os valores, as almas, as linguagens, os corpos do povo” (p. 29). Por esta razão, acreditamos que o desfile da Tuiuti pode atuar como um potente dispositivo de "sobrevivência dos vaga-lumes”. O desfile da política acabou por suscitar significativas pautas 
de debates acerca do papel dos sujeitos e da natureza de suas manifestações no atual cenário brasileiro.

O diálogo que estabelece Sloterdjik com Canetti, no livro "O desprezo das massas", sobre a diferença entre povo e massa sugere que "entra em colapso a visão romântico-social do sujeito democrático, que poderia saber o que quer; dissipou-se o sonho do coletivo autotransparente” (2002, p. 16). Tal reflexão é oportuna para melhor caracterizar os sentidos das reações representadas pelo desfile da Tuiuti. Com a "necessidade de descarga da massa", a festa do carnaval torna-se uma fervilhante esfera de visibilidade e de produção imaginária de outro modo de se conceber o poder. As ruas passam a constituir portais de liberação de emoções represadas, espelhando o esgarçamento da velha ordem política. Considerando que "ainda pode reunir-se e aparecer diante de si mesmo como multidão presente - com um tom singular, uma excitação singular e um ato singular", pergunta Sloterdjik (2002, p. 19), o carnaval, no caso, a festa atuaria como um modo de reunião de uma "multidão presente"? Para o autor, a multidão, transfigurando-se no seu inconsciente coletivo, libera as emoções reprimidas e arcaicas como se estivesse navegando uma nau de sobreviventes:

Só em raros momentos quando em festivais populares a massa da felicidade é fundida num corpo coletivo extático, ainda brilha através da apatia pós-moderna uma centelha dos dionísios políticos e das reuniões da multidão lúcida despertada por si mesma - especialmente tão logo uma tonificante música pop, pronta para o uso, proporcione para os reunidos excitação e descarga (SLOTERDJIK, 2002, p. 24).

Como se os ritmos da festa, em raros e significativos momentos, atravessassem as camadas sutis do pensamento e do corpo para liberar o não-dito e o não-percebido. Vale lembrar que tanto a festa quanto o jogo atuam como dispositivos, tal qual sugere Duvignaud (1983, p. 68), "provindos fora do sistema”, para pôr em xeque a ordem social. A festa, atuando como suspensão da vida "ordinária", possibilita que outros códigos e ritos se instalem nos labirintos dos sonhos e do cotidiano ${ }^{21}$. A vivência do extraordinário produz

21 Na festa, lembra Duvignaud (1983), há um jogo que aponta para uma evasão da vida "real” (p. 11). "A festa é tudo isto, quer utilizando provisoriamente os signos coletivos ou as classificações consagradas e, destarte, aproximando-se das experiências rituais, quer colocando-se de passagem, ou a serviço de um poder, quer atingindo o transe, o êxtase". E complementa: "ela destrói ou abole, em sua vigência as representações, os códigos, as normas por meio das quais as sociedades se defendem contra a agressão natural” (DUVIGNAUD, 1983, p. 69). 
o prazer do horizonte onde se vive extaticamente os limites do sagrado e do profano, o que é bem destacado por Johan Huizinga:

\begin{abstract}
Existem entre a festa e o jogo, naturalmente, as mais estreitas relações. Ambas implicam uma eliminação da vida quotidiana. Em ambos predominam a alegria, embora não necessariamente, pois a festa também pode ser séria. Ambos são limitados no tempo e no espaço. Em ambos encontramos uma combinação de regras estritas (no segundo desfile foi pedido para 'o vampiro Temer' não usar a faixa presidencial) com mais autêntica liberdade (2001, p. 25 - parênteses nossos).
\end{abstract}

Por não se constituir em nenhuma finalidade causal e se revelar apenas como o paradoxo de si mesma, a festa atravessa o domínio da percepção racional e deixa emergir "dimensões ocultas". No desfile da Tuiuti, ela fez eclodir cenas "invisíveis” da história do Brasil que não são levadas em conta pela narrativa do poder oficial, mas que constituem o horizonte em que se desenham as contestações.

A festa gera coragem onde não havia; transgressão onde estava o conformismo; raiva trêmula onde reinava o medo mortal. Transe vivido nas encruzilhadas do transitório, o carnaval é a festa em sentido pleno (DUVIGNAUD, 1983, p. 69): Cerimônia lúdica em que se libertam as fantasias escondidas e os corpos reprimidos, em que a política se transfigura não mais por discursos moralistas, mas por um fazer dramático aberto ao passado e ao futuro. A festa atinge aquilo que constitui a última finalidade das comunidades, isto é, um mundo reconciliado, uma entidade fraternal (DUVIGNAUD, 1983, p. 69). No caso do desfile, o efeito foi contrário a qualquer conciliação. Houve a "quebra" da ilusão do poder, uma cisão de qualquer suposto princípio de "entidade fraternal”, reação limite contra o desaparecimento da política convencional, gesto de denúncia contra as manipulações midiáticas que, muitas vezes, desviam o inconformismo para telas vazias.

Lembrando Giorgio Agamben (2007), podemos perguntar se a Escola de Samba Tuiuti "profanou” a imagem do poder. O termo profanação, para este autor, tem seu sentido mais destacado na religião, como sendo "aquilo que subtrai as coisas, lugares, animais ou pessoas ao uso comum e as transfere para uma esfera separada” (p. 65). É transgressão de espaço e de tempo aprisionados para que se possa recriar o prazer da desobediência onde ele 
tinha se escondido do imaginário autoritário ${ }^{22}$. São rituais que reinauguram a significação do viver coletivo, que dão sentido ao falado, ao imaginado, ao figurado, que religam o humano à sua pluralidade onírica, a qual é comumente omitida pela política do banal.

Indaga ainda Agamben se existe sociedade sem separação. Profanar não significa simplesmente abolir e cancelar as separações, mas aprender a fazer delas um uso, a brincar com elas (AGAMBEN, 2007, p. 75). Daí decorre a expressão multidão, conforme trabalhada por Michael Hardt e Antonio Negri (2005), fazer sentido no âmbito dessa abordagem na medida em que ela permite estabelecer, simultaneamente, a multiplicidade e a singularidade. Dizem Hardt e Negri:

O povo é uno [...]. A multidão, em contraste, não é unificada, mantendo-se plural e múltipla. Por isto, seguindo a tradição dominante da filosofia política, é que o povo pode governar como poder soberano, e a multidão, não. A multidão é composta de um conjunto de singularidades - e com singularidades queremos nos referir a um sujeito social cuja diferença não pode ser reduzida à uniformidade, uma diferença que se mantém diferente (2005, p. 139).

Na festa, a multidão se desloca para a celebração coletiva da morte do rei ou da exaltação do novo messias. Entre o sagrado e o profano, entre a religião e a política, a figura de Dionísio ${ }^{23}$ emerge como portador do cálice que liberta o imaginário estético popular oprimido. Contudo, a multidão, embora se mantenha múltipla, não é fragmentada, anárquica, incoerente. Daí ser importante contrastar este conceito com uma série de outros que designam entidades coletivas plurais, como a turba, as massas e o populacho, se bem entendemos a proposta de Hardt e Negri (2005, p. 140). Nas ruas, a multidão é a esperança de olhos frustrados. Ela libera a utopia de outros mundos, realça o prazer do sagrado e desfaz a castração do poder. Ela aponta na sua multidimensionalidade o imaginário instituinte, que se revela nas brechas

22 Citando Hubert e Mauss, Agamben reitera que "o que foi separado pode ser ritualmente restituído, mediante o rito, à esfera profana [...] A passagem do sagrado ao profano pode acontecer também por meio de um uso (ou melhor, de um reuso) totalmente incongruente do sagrado. Trata-se do jogo. Sabe-se que as esferas do sagrado e do jogo estão estritamente vinculadas" (2007, p. 66), acrescentando, assim como a esfera da festa.

23 Dioniso, ou Dionísio, era o Deus grego equivalente ao deus romano Baco, dos ciclos vitais, das festas, do vinho, do delírio, mas, fundamentalmente, do excesso, do prazer e do êxtase. 
do sistema de poder oficial e no calor das ruas, para desfazer o antigo imaginário instituído, o qual não pode mais conter a exuberância desta sociedade de emoções intensas.

\section{Algumas linhas conclusivas: por onde ressoa o grito da escola?}

O desfile da Tuiuti faz surgir um regime, para além do meramente representativo, que perfaz linhas de conexão entre estética e política. Lembra aquilo que Rancière (2009, p. 25) aponta como sendo a abolição "das relações entre o visível e o dizível, o saber e a ação, a atividade e a passividade”. O "regime estético", ao contrário do estritamente representativo, segundo este autor (2009, p. 77), seria próprio do "ser da arte", pois "precisa valorizar a potência surda de uma palavra do Outro, irredutível a toda hermenêutica". Além "do visível” que ganha a avenida, o desfile da Tuiuti deixa óbvia a correlação entre "festa” e "política”; personagem como o "vampiro neoliberal" intensifica a potência do "inconsciente estético", trazendo à luz do dia cenas marcantes e cruéis da história política brasileira.

A Tuiuti trouxe, nos adornos, máscaras, fantasias e adereços, detalhes de cenas da cultura política brasileira que parecem, usando reflexão de Rancière (2009, p. 59), dar "lugar à verdade do inconsciente que não é a de uma história individual, mas que é a oposição de uma ordem a outra, o figural sob o figurativo, ou o visual sob o visível representado”. Política e estética conectam-se na paisagem do enredo da Tuiuti, traduzindo significativas cenas da cultura brasileira que transpiram as formas rebeldes do imaginário barroco desta sociedade pós-colonial.

No imaginário coletivo, o vasto material gerado pelo impacto do desfile intitulado “Meu Deus! Meu Deus! Está extinta a escravidão?” sugere haver no ar algo mais do que a simples morte ou refluxo da democracia brasileira sob o peso do conservadorismo. As reflexões que procuramos desenvolver no presente texto sugerem ter recrudescido com a Tuiuti um tipo de dimensão tática, como diria De Certeau (1994), em oposição às estratégias de desmobilização da vida pública encetadas pelo Estado. Tal dimensão tática contribui para promover dispositivos de "politização do social” (COUTINHO, 1994), que explodem a velha maneira de organização da sociedade oligárquica fundada no culto do mandonismo e da subserviência. Para além 
do caráter meramente celebrativo da festa carnavalesca, a nova estratégia do público democrático emerge como imaginário instituinte por meio de signos estampados em carros e alas e nas emoções que conduzem os protagonistas da festa. A celebração potencializa, assim, novos fluxos do ato de experimentar e fazer política. O desencanto com a velha política parece possibilitar a insurgência de outros referentes imaginários expressos pela brincadeira carnavalesca ${ }^{24}$.

O desfile da Tuiuti em 2018 evidencia a erosão da vida pública, num sistema político que desvaloriza o bem comum e assegura os privilégios das elites oligárquicas nacionais e internacionais. Isso nos leva a refletir, com Richard Sennett (1988, p. 18), sobre "quais os tipos de expressão de que é capaz o ser humano nas relações sociais” quando o cenário instaura um “declínio do homem público”. E, acrescentamos, declínio numa sociedade que, paradoxalmente, pouco conseguiu estabelecer o homem público como base de uma cidadania democrática. Portanto, a multiplicação dos signos de identificação do humano com os sonhos da liberdade nesse tipo de sociedade pós-colonial rompe a tese do politicamente correto permitido para instaurar novas ordens possíveis e, assim, reinventar a desordem produzida pela colonialidade. Nos enlevos da festa e nas táticas cotidianas, os ritos de rebeldia acabam por revelar desejos intensos de libertação do corpo individual e social e da produção de outros imaginários possíveis que acenam para uma abolição concreta, e não apenas formal da cultura da escravidão.

Enfim, vale pensar no desfile da Tuiuti como uma expressão da "cultura no plural" (CERTEAU, 1995, p. 95), até como um "ato violento que assinala a irrupção de um grupo” (p. 95). O desfile do carnaval autentica o querer-existir de uma minoria (no caso do Brasil, uma minoria-maioria) que procura se constituir em um universo em que ela é excedente porque ainda não se impôs. Na passagem do anonimato para a glória, a Tuiuti carregou nos seus ombros os fardos dos abandonados e as esperanças dos rebeldes. A Escola traduziu a violência que tem recortado a história do Brasil por meio de adereços, pinturas, algemas, chicotes, fantasias e máscaras.

Nos limites da rebelião estética, libera-se um tanto da alma incontida,

24 Tal qual alude S. Freud (1990), temos um quadro em que as pulsões de vida (eros) daquela parte da sociedade desencantada com os usos arbitrários do poder liberam-se para minimizar as pulsões de morte (tânatos), expressas nos suplícios da escravidão que ainda habitam dolorosamente as memórias das populações vulneráveis. 
revitalizando as memórias individuais e coletivas de tempos da escravidão, do esquecimento, dos sonhos frustrados, de vozes que gritam e rompem grilhões nos ecos de um samba-enredo: "Senhor, eu não tenho a sua fé, e nem tenho a sua cor/ Tenho sangue avermelhado/ O mesmo que escorre da ferida, mostra que a vida se lamenta por nós dois”. O que desfaz e o que instaura apenas o tempo dirá.

\section{Referências bibliográficas}

AGAMBEN, Giorgio. (2007), Profanações. 1 ed. São Paulo: Boitempo.

ALENCASTRO, Luis Felipe de. (2000), O Trato dos Viventes: formação do Brasil no Atlântico Sul. 7 ed. São Paulo: Companhia das Letras.

APPADURAI, Arjun. (2004), Dimensões culturais da globalização. 1 ed. Lisboa: Teorema.

ARAÚJO, Rita de C. B. de. (1997), Carnaval do Recife: a alegria guerreira. Estudos Avançados, v. 11, n. 29, pp..203-216

CARVALHO, José Murilo. (2002), Cidadania no Brasil. O longo caminho. 3 ed. Rio de Janeiro: Civilização Brasileira.

CASTORIADIS, Cornelius. (1982), A instituição Imaginária da Sociedade. 1 ed. Rio de Janeiro: Paz e Terra.

COUTINHO, Carlos Nelson. (1994), Marxismo e política: a dualidade de poderes e outros ensaios. 1 ed. São Paulo: Cortez.

DE CERTEAU, Michel. (1995), A cultura no Plural. 1 ed. São Paulo: Papirus.

DE CERTEAU, Michel. (1994), Invenção do Cotidiano - as artes de fazer. 2 ed. Petrópolis: Vozes.

DELEUZE, Gilles; GUATTARI, Félix. (1997), Mil Platôs - Capitalismo e Esquizofrenia Vol. 5. 1 ed. São Paulo: Ed. 34.

DIÓGENES, Glória. (1993), "Modernidade, Identidade e Movimentos Sociais”. In: BARREIRA, Irlys; NASCIMENTO, Elimar (org.). Brasil Urbano - cenários da ordem e da desordem. Fortaleza; Rio de Janeiro: Notrya. pp. 49-65.

DUVIGNAUD, Jean. (1983), Festas e civilizações. 1 ed. Fortaleza: Edições UFC.

DIDI-HUBERMAN, Georges. (2011), Sobrevivência dos vaga-lumes. 1 ed. Belo Horizonte: Ed. UFMG.

FREUD, Sigmund. (1990), Obras psicológicas completas de Sigmund Freud. 
Edição standard brasileira. Psicologia de Grupo e a Análise do Ego. 1 ed. Rio de Janeiro: Imago.

GORENDER, Jacob. (1978), O escravismo colonial. Rio de Janeiro: Ática.

HARDT, Michael; NEGRI, Antônio. (2005), Multidão - guerra e democracia do Império. Rio de Janeiro; São Paulo: Record.

HUIZINGA, Johan. (2001), Homo Ludens. 5 ed. São Paulo: Perspectiva.

IPEA. (2017), Atlas da Violência 2017. Disponível em: http:/www.ipea.gov. br/atlasviolencia/download/2/2017. Acesso em: 05 mar. 2018.

GUATTARI, Félix; ROLNIK, Suely. (2010), Micropolítica: Cartografias do desejo. 9 ed. Rio de Janeiro: Vozes.

HOBSBAWM, Eric. (1982), A Era das revoluções. Rio de Janeiro: Paz e Terra.

MARTINS, Paulo Henrique. (2002), "Cultura autoritária e aventura da brasilidade”. In: BURITY, Joanildo A. (org.). Cultura e identidade: perspectivas interdisciplinares. 1 ed. Rio de Janeiro: DP\&A. pp. 65-104.

NABUCO, Joaquim. (2000), O abolicionismo. São Paulo: Publifolha.

RANCIÈRE, Jacques. (2009), O inconsciente estético. 1 ed. São Paulo: Ed. 34.

RANCIÈRE, Jacques. (2011), O destino das Imagens. 1 ed. Lisboa: Orfeu Negro.

RIBEIRO, Ana Clara Torres (1993), Apresentação. In: BARREIRA, Irlys; NASCIMENTO, Elimar (org.). Brasil urbano - cenários da ordem e da desordem. Fortaleza; Rio de Janeiro: Notrya. pp. 11-14.

SAMAIN, Etienne. (2012), O que pensam as imagens? 1 ed. Campinas: Ed. Unicamp.

SENNETT, Richard. (1988), O declínio do homem público - As tiranias da intimidade. 1 ed. São Paulo: Companhia das Letras.

SCHERER-WARREN, Ilse; KRISCHKE, Paulo. (1987), Uma revolução no cotidiano? - Os novos movimentos sociais da América do Sul. 1 ed. São Paulo: Brasiliense.

SLOTERDJIK, Peter. (2002), O desprezo das massas - ensaio sobre lutas culturais na sociedade moderna. 1 ed. São Paulo: Estação Liberdade.

SOARES, Carmen. (1998), Imagens da Educação no Corpo. 1 ed. Campinas: Autores Associados.

SOUZA, Jessé. (2017), A elite do atraso. Da escravidão à Lava Jato. ed. Rio de Janeiro: Leya.

TOCQUEVILLE, Alexis de. (2005), A democracia na América. Leis e costumes, Livro 1. 2 ed. São Paulo: Martins Fontes. 
WARBURG, Aby. (2015), Histórias de Fantasmas para gente grande - escritos, esboços, conferências. 1 ed. São Paulo: Companhia das Letras.

WEBER, Max. (2004), A ética protestante e o espírito do capitalismo. São Paulo: Companhia das Letras. 


\title{
Encontros entre Paulo Freire e Amílcar Cabral: a Crítica Pós-colonial e Decolonial em Ato
}

\author{
Adelia Miglievich-Ribeiro*
}

\section{RESUMO}

A contemporânea crítica pós-colonial converge com o atual "giro decolonial" latino-americano na revisão da narrativa da modernidade monolítica (eurocêntrica) de maneira a se propor o remapeamento dos "loci" de produção acadêmica no mundo. Busco demonstrar que a inspiração de um e outro movimento pode ser localizada numa excepcional rede intelectual que se potencializou com o exílio de estudiosos, professores e pesquisadores críticos que, nos anos 1960-70, foram expulsos de seus países com a instalação das ditaduras militares. Elejo Paulo Freire em suas reflexões sobre educação e descolonização para visibilizar sua interlocução com o pensamento do "pedagogo revolucionário" Amílcar Cabral. Examino os aprendizados de Paulo Freire em Guiné-Bissau no empenho de colaborar na fundação de uma nova nação mediante a educação de um povo. A experiência revelaria ao educador brasileiro as contradições do colonialismo e a árdua tarefa de se "expurgar" do colonizado a sombra do colonizador.

Palavras-chave: Paulo Freire. Guiné-Bissau. Colonialismo. Descolonização.

* Doutora em Sociologia (PPGSA/IFCS/UFRJ), com Pós-Doutorado em Educação (ProPedUERJ-Faperj); professora do Departamento de Ciências Sociais, atuando ainda como docente permanente no PPG Sociologia e no PPG Letras, da Universidade Federal do Espírito Santo (UFES). É pesquisadora produtividade do CNPq (nível 2), com taxa de pesquisa FAPES. 


\begin{abstract}
THE ENCOUNTER OF PAULO FREIRE AND AMÍLCAR CABRAL: THE POSTCOLONIAL AND DECOLONIAL CRITICISM IN ACT.
\end{abstract}

The contemporary post-colonial critique converges with the current Latin American "colonial spin" in the revision of the narrative of monolithic modernity (Eurocentric) In order to propose the remapping of the "loci" of academic production in the world. I seek to present that the inspiration of both movements can be found in an exceptional intellectual network that got enhanced with the exile of scholars, teachers and critical researchers who, in the 1960's and 70's, were purged from their countries with the placement of military dictatorships. I approach Paulo Freire in his reflections on education and decolonization to give visibility to his interlocution with the thought of the "revolutionary educator" Amílcar Cabral. I look upon the learning of Paulo Freire in Guinea Bissau in his effort to collaborate in the foundation of a nation through education of its people. The experience reveals to the Brazilian educator the contradictions of colonialism and the arduous task of "purging" the Colonizer's shadow from the Colonized.

Keywords: Paulo Freire. Guiné-Bissau. Colonialism. Decolonization.

\title{
Apresentação
}

A crítica pós-colonial sabe que seu pós não significa a superação dos antigos colonialismos e dos traumas inscritos e reiterados nos neocolonialismos. Há na ideia de pós a pretensão, porém, de que tal elaboração crítica expresse um passo além no modo como víamos o mundo e que, agora, inclui o ponto de vista dos colonizados em luta por sua descolonização. Em sua aproximação com o pós-estruturalismo francês, a crítica pós-colonial descobriu, no jogo de palavras que o francês propicia, a noção de différance ("diferança”) de Jacques Derrida (1991), que recusa as bipatições e dicotomias entre um Eu e um Outro absolutamente opostos e as substitui por complexos emaranhados de diferenças e semelhanças que desalojam as identidades fixas e monolíticas. Desde então, proclama-se que não há uma única modernidade, se não múltiplas e entrelaçadas, hibridizadas e em permanente tensão, de modo que a configuração moderna que produziu a experiência do colonizador também produziu a do colonizado, assim como a riqueza de um pode ser explicada na miséria do outro, o privilégio do primeiro pela desumanização do segundo. Cultura/civilização e barbárie, em consonância com a assertiva 
de Walter Benjamin (1985), escrita em 1940, que não falava do colonialismo, porém do nazismo na Europa, se diluem numa única substância e nunca mais se separam.

O pós-colonial, marcadamente uma reflexão nascida na África e na Ásia na segunda metade do século XX, dialoga com o "giro decolonial"1 latino-americano, que, por sua vez, se remete à "rica tradição cognoscitiva" no continente desde o século XIX, e mesmo antes. Um coletivo de intelectuais autodenominado Modernidade-Colonialidade-Decolonialidade reivindica tal passado e, mediante a produção do pensamento liminar ${ }^{2}$, propõe o "reordenamento da geopolítica do conhecimento" a fim de que um mundo de histórias locais possa ser contemplado para redesenhar a história da modernidade, ou melhor, das modernidades. Não se trataria de uma "contracultura ‘bárbara’ perante o Primeiro Mundo”, mas da expressão de uma autodeterminação política, teórica e epistemológica dos loci ainda não inscritos dentre os produtores do conhecimento (MIGNOLO, 2003, p. 417-418).

Nomes e correntes como Waman Poma de Ayala, no século XVII³; José Carlos Mariátegui, Víctor Raúl Haya de la Torre, Caio Prado Jr., os dependentistas da década de sessenta, a teologia da libertação, a filosofia da libertação, a antropologia dialética de Darcy Ribeiro, o pensamento revolucionário de Florestan Fernandes, as tematizações do "colonialismo interno” por Pablo Gonzáles Casanova, dentre tantos, compõem um acervo que se pode articular ao pós-colonial nascido na África e ao atual “decolonial” latino-americano.

1 Uso indistintamente "giro decolonial" e "giro descolonial” (com "s"), em que pesem alguns pesquisadores como Catherine Walsh operar com a distinção entre ambos os conceitos. O giro "descolonial”, para ela, refere-se, sobretudo, às lutas independentistas que marcaram, no século XIX, as nações latino-americanas. Enquanto o "giro decolonial” fala não de uma superação in toten, datada historicamente, mas de movimentos ininterruptos de resistência que se passam, também, nas dimensões subjetivas. Cf. Walsh, 2013.

2 O pensamento liminar é a "enunciação fraturada em situações dialógicas com a cosmologia territorial e hegemônica” (MIGNOLO, 2003, p. 11). Abarca assim tudo que não foi narrado quando se inventaram o ocidentalismo e o orientalismo, estereótipos que serviram à redução, logo, ao falseamento do Outro. Nesse sentido, destaca, também, as críticas aos Estudos de Área, que manipularam povos, territórios e conhecimentos, ao capturá-los tão somente sob as lentes do $1^{\circ}$. Mundo, que inventou, vale lembrar, o terceiro-mundismo, ao mesmo tempo em que o descaracterizava.

3 Nas lutas de contestação colonial e na independência do Haiti, mais especialmente, Felipe Guama Poma de Ayala escreveu, em 1615, Nueva crónica y buen gobierno. A obra, alentada, analisa o desastre da colonização espanhola sobre o Império Inca, ao mesmo tempo em que discorre sobre um possível bom governo espanhol a partir da cosmologia incaica. $\mathrm{O}$ "giro decolonial" contemporâneo aponta tal estudo como comparável aos textos de Hobbes, Locke e Rousseau que também se voltam às formas de governo desejáveis numa sociedade, exceto que negligenciado numa pré-definida "geopolítica do conhecimento". Vale conferir Guaman Poma de Ayala, 1980. 
Os trânsitos de ideias são materializados desde o deslocamento de corpos ao de instituições. As diásporas são verídicas assim como os exílios. É o caso de uma geração específica de intelectuais brasileiros que, após o Golpe Militar de 1964, se espraiou pela América Latina e pelo mundo, constituindo redes inéditas. Assim é que, inspirarados em Fidel Castro, Che Guevara, Camilo Torres, aproximaram-se, também, dos ideais revolucionários das guerras de libertação na África, lendo, dentre outros, Frantz Fanon, Amílcar Cabral e Agostinho Neto, tendo sido tocados ainda por Malcom X e Eldridge Cleaver.

Elejo, neste artigo, Paulo Freire (1921-1997), a fim de explicitar a formulação de um pensamento educacional - referência, até hoje, em diversos países do mundo - que se construiu na descoberta e, sobretudo, no encontro das diferenças, nas experiências de desolação e de esperança, na mistura de influências ao sabor de um projeto ético-epistemológico-político.

Detenho-me, propositalmente, em seus aprendizados na África, quando lá se empenhou no esforço coletivo de fundação das novas nações, para elaborar a hipótese de que a pedagogia histórico-crítica de Paulo Freire, em sua intenção em "descolonizar mentes", antecipa, jamais sozinha, o atual "giro decolonial” e o ponto de vista pós-colonial. Não se trata de dizer que se confundem, mas atestar que não há pensamento nascido no vácuo e o diálogo entre gerações e vertentes do pensamento pode potencializar a crítica ao se ampliar a "comunidade de fala". Em Freire, estão contidos diversos outros intelectuais cujo pensamento é por ele revisitado de forma original. Também Freire está contido nas atualizações do pós-colonial e do decolonial. O processo de conhecimento requer a atenção aos confrontos e superações, não menos aos encontros que, tal como busco expor, ampliam e fortalecem a inteligibilidade do mundo e a intervenção humana nele.

\section{Paulo Freire: um intelectual das margens}

É curioso que se possa identificar no pensamento freiriano uma conjugação entre existencialismo cristão, fenomenologia e marxismo. Sua pedagogia tem como fontes de referência Emmanuel Mounier, filósofo da práxis, Gabriel Honoré Marcel e Karl Jaspers, este último de forte influência sobre Martin Heiddeger e Hannah Arendt. Há ainda o vínculo com a filosofia da educação de John Dewey, pragmatista. Combina, desse modo, uma "dialética de consciências" com o método fenomenológico existencial, de Marcel e Jas- 
pers, de forma a perceber o diálogo como intimamente relacionado à práxis (o "aprender fazendo"), realizada no trabalho cooperativo, produtor e produzido da/pela linguagem. Como fenomenólogo, deduz, portanto, a "verdade" da relação entre sujeitos capazes de produzir uma "consciência do fenômeno”, na compreensão de seus sentidos/significados. A ontogênese da teoria freiriana apoia-se, assim, na formulação de que o mundo não é, o mundo está sendo (ZANELLA, 2010)

Freire tem sua condição intelectual forjada na efervescência intelectual dos anos 1920. Neste tempo, nomes destacados como Fernando de Azevedo, Anísio Teixeira e Lourenço Filho empenham-se na formulação de um projeto de educação de caráter liberal, mas que, sob a bandeira escolanovista, também abarcavam a luta pela escola pública, gratuita, obrigatória e leiga no Brasil, em oposição à primazia do ensino clerical. Mas o recente conceito de "povo" como uma expressão política mais efetiva da "res"pública ainda precisaria amadurecer. Apenas nos anos 1950, entre períodos autoritários com "intervalos” democráticos, novas práticas e reflexões acerca da educação possibilitariam sua maior organicidade com as demandas de igualdade social (SAVIANI, 1984).

Numa peculiar "estrutura de sentimentos", ou "estrutura prática de um tempo presente", nos termos de Raymond Williams (2011), portanto, é que Paulo Freire pôde se engajar nas causas emancipatórias das classes populares. Tal é a ambiência que fez o pernambucano, nascido na cidade de Recife, o jovem bacharel em Direito deixar as leis e os tribunais para se dedicar à causa educacional concebida como projeto cultural revolucionário para o Brasil, capaz de produzir sujeitos (educandos e educadores num só tempo), protagonistas de sua existência.

Entre 1962 e 1963, Paulo Freire atuou em Angicos, no estado do Rio Grande do Norte, alfabetizando. Estimulava seus alunos e suas alunas à tomada de consciência de seu "lugar" no mundo, na observação de seu entorno, na valorização de seus saberes, convertendo cada um(a) deles(as) em pesquisador(a) do universo cultural (e vocabular) no qual estavam imersos. Seu método consistia nos grupos elencarem os termos do cotidiano que faziam real sentido em seu universo cognitivo, posto que os afetavam. Nasciam, assim, as palavras geradoras. O gesto de partir do que era valioso para o trabalhador e para a trabalhadora permitiu a Paulo Freire e seus colaboradores alfabetizar cerca de 300 homens e mulheres num prazo recorde de 45 dias. 
Após esse feito, Paulo Freire teve sua proposta educacional conhecida na esfera federal e, por convite do Ministro da Educação, Paulo de Tarso Santos, foi convocado para presidir a Comissão Nacional de Cultura Popular e coordenar o Plano Nacional de Educação do governo de João Goulart.

Numa interlocução com vários isebianos, nacionalistas anticolonialistas (ORTIZ, 1995), dentre eles, Álvaro Vieira Pinto - que reencontrou no exílio chileno -, Paulo Freire iniciou, também, suas leituras de Frantz Fanon e Albert Memmi, na busca da compreensão do árduo e doloroso processo de "exorcismo" do opressor internalizado no oprimido que implicava a superação da brutal ansiedade que, no "dominado", gera seu próprio medo da liberdade. Freire tomava, então, para si os conceitos fundamentais de "alienação" e de "situação colonial”. Em seu Pedagogia do Oprimido (1987), publicado uma década depois, em 1974, Paulo Freire citaria nominalmente ambos os textos fundantes do assim chamado pós-colonial:

[...] li em Sartre (prefácio a Os condenados da terra, de Frantz Fanon) [...] uma das expressões da "conivência" dos oprimidos com os opressores. [...] Tudo isso os estimulava [os camponeses espanhóis] como a mim me estimulara a leitura de Fanon e de Memmi, feita quando de minhas releituras dos originais da Pedagogia. Possivelmente, ao estabelecerem sua convivência com a Pedagogia do oprimido, em referência à prática educativa que vinham tendo, devem ter sentido a mesma emoção que me tomou ao me adentrar nos Condenados da terra e no The colonizer and the colonized. Essa sensação gostosa que nos assalta quando confirmamos a razão de ser da segurança em que nos achamos (FREIRE, 1992, p. 141)

O Plano Nacional de Alfabetização de Adultos, lançado em janeiro de 1964, é, contudo, interrompido bruscamente com a deposição de João Goulart pelo golpe militar dois meses depois. Paulo Freire é preso e, depois, obrigado a buscar a Bolívia como primeiro asilo. Na complexa semântica do exílio, segundo Gasparini (2011), tem-se uma temporalidade em que o presente é colocado entre parênteses, dando lugar a uma outra realidade em que predomina o futuro, tornado o "espaço utópico”. Quando o exílio deixa de ser uma realidade individual e passa a marcar uma geração, como no caso estudado, temos fronteiras deslocadas e o surgimento de entrelugares (SANTIAGO, 2006). Das "margens", o intelectual periférico, como propõe Piglia, lança ao mundo sua "mirada estrábica” (PIGLIA, 2001), que se distin- 
gue diametralmente daquela do intelectual metropolitano. Podemos também falar de uma "desestabilização epistemológica”, necessária à reflexão crítica, capaz "de romper os pactos hegemônicos do uniforme e do conforme" (RICHARD, 2002, p. 169).

Quando a Bolívia também o expurga, Paulo Freire segue para o Chile, onde viveu por cinco anos em tempos da euforia em torno do governo Allende. Convivendo com diversos outros intelectuais também atraídos pelo “clima” chileno, tais como Álvaro Vieira Pinto, Francisco Weffort, José Luiz Fiore, Marcela Gajardo, Jacques Chonchol, Jorge Mellado, Juan Carlos Sampaio, Raúl Velozo, Paulo de Tarso, Plínio Sampaio, Almino Affonso, Maria Edy, Flávio Toledo, Wilson Cantoni, Ernani Fiori, João Zacariotti, Antonio Romanelli, Paulo Freire avançou em suas reflexões. Atuando como assessor do Instituto de Desarollo Agropecuario, do Ministério da Educação, e como consultor da UNESCO, junto ao Instituto de Capacitación e Investigación en Reforma Agraria do Chile, coordenou um plano de alfabetização que deu àquele país o "Prêmio UNESCO de combate ao analfabetismo". Foi também em Santiago que publicou Educação como Prática da Liberdade, no ano de 1967, inaugurando uma ininterrupta escrita que o tornou rapidamente um dos mais lidos pensadores mundiais da educação do século XX.

Com o Golpe de Pinochet contra Allende, Freire foi para os Estados Unidos, convidado para lecionar na Universidade de Harvard. Foi quando recebeu a proposta de para ser consultor especial do Departamento de Educação do Conselho Mundial de Igrejas (CMI), em Genebra. Mudou-se para a Suiça, lecionou na Universidade de Genebra e fundou, junto a outros brasileiros exilados - Miguel Darcy de Oliveira, Rosiska Darcy de Oliveira, Claudius Ceccon -, o Instituto de Ação Cultural (Idac) ${ }^{4}$, cuja missão era desenvolver pesquisas visando à conscientização, libertação e transformação social.

Em 1975, como membro do CMI e do Idac, Paulo Freire com sua equipe, a convite do Ministro da Educação, Mário Cabral, do novo governo de Luís Cabral, sucessor de Amílcar Cabral, "abraçou” o intento de elaborar e exe-

4 Freire foi eleito imediatamente presidente do Idac. Nos anos seguintes, o Instituto alcançou inédito nível de popularidade, com os pedidos de colaboração incessantes para realizar seminários e oficinas por todo o mundo. Preocupado com o fato de o instituto quase se tornar um "guru" de uma comunidade intelectual, o que contrariaria seus princípios pautados na vivência, Paulo Freire chegou até mesmo a parar de usar o termo "conscientização" (GERHARDT, 1996, p. 163). 
cutar um programa nacional de alfabetização em Guiné-Bissau que pudesse concorrer para a construção da nova nação.

\section{2 "Descolonizando mentes" em torno de um projeto de nação: Amílcar e Freire}

Amílcar Cabral (1924-1973) nasceu em Guiné-Bissau, filho de pais cabo-verdianos, líder da luta colonial guineense e do Partido Africano para Independência da Guiné e Cabo Verde (PAIGC), a primeira organização de libertação das colônias portuguesas, fundada em 1956. Freire e Amílcar não se conheceram pessoalmente, mas o enfático compromisso com a descolonização das mentes do segundo marcou indelevelmente o pensamento freiriano. Acompanhando, de longe, os processos de libertação em África, o intelectual brasileiro sustentava, tal como o líder revolucionário, a convicção da urgência do combate ao sistema colonial, à superação da ideologia colonial. No contato com Os Condenados da Terra, de Fanon, Freire, sem ser, em absoluto, um apologista da violência, até mesmo por sua prévia aposta na Educação aliada à sua formação cristã, aceitou a luta armada como último recurso para a reconquista da liberdade. Distinguia, assim, a violência dos opressores daquela dos oprimidos revolucionários. A primeira garantia o prosseguimento da violência (a exploração e a desumanização do Outro), a segunda visava estancar e suprimir definitivamente a prática da violência (FREIRE; GUIMARÃES, 2011, p. 53).

Era o trabalho pedagógico de Amílcar Cabral, contudo, que mais poder de atração exercia sobre Freire. Para ambos, o êxito de qualquer operação militar dependia fundalmentalmente da "descolonização das mentes", isto é, da capacidade dos guineenses militantes, conscientes de sua história, assumirem por que e por quem lutavam. Novamente, em sintonia com Amílcar, Paulo Freire entendia a "necessidade da libertação cognitiva, da superação da racionalidade imbricada pela colonialidade" (ROMÃO; GADOTTI, 2012, p. 15), no que a escola tem um papel fundamental.

A admiração pelo pedagogo da revolução é registrada por Paulo Freire na dedicatória de seu livro Cartas à Guiné-Bissau: registros de uma experiência em processo (1978), publicado pela primeira vez em 1977. Amílcar Cabral concebia a reafricanização da vida como exigência de um processo pedagógico que se quer libertador. Freire aceitou o pressuposto da descolonização das 
mentes, antecipando, conforme aqui defendido, os reclames do "pós-colonial" e do "giro decolonial" contemporâneos como requisito na formação de uma nação independente. Tratava-se de superar a ideologia colonialista e racista que convencia homens e mulheres no território de uma suposta "inferioridade humana" perante os colonizadores europeus, os quais impunham a assimilação e a consequente deculturação como única "salvação" para os que eram por eles chamados preconceituosamente de "pretos de alma branca".

O PAIGC, sob a liderança de Amílcar Cabral, formou jovens em nível médio e superior. Nos dez anos de guerra pela libertação, nas chamadas "zonas libertadas”, teve acesso à educação um número maior de pessoas nativas do que nos 500 anos de sistema colonial. A guerra de libertação havia tido início com a brutal repressão pela PIDE (Polícia Internacional para a Defesa do Estado) aos trabalhadores portuários nas docas do cais de Pidjiguiti, no ano de 1959, em greve organizada pelo PAIGC. O episódio marcou a decisão histórica pela mobilização das massas camponesas e pelo esforço das organizações políticas nos meios urbanos de onde se desencadeou uma "onda" de intensas ações, como greves e manifestações, ao preço, porém, de muitíssimas vidas. Abandonavam-se, portanto, os métodos pacíficos em favor da luta armada.

Os pequenos grupos de guerrilha nas regiões de floresta multiplicaram-se e se transformaram em unidades importantes porque impossíveis de serem localizadas pelas forças coloniais, movimentando-se muito rapidamente em longas distâncias. Em 23 de janeiro de 1963, explodiu, ao sul do território, o ataque ao quartel de Tite, acirrando-se a luta armada que não mais tinha qualquer contenção até 1967. Na análise de Paulo Freire:

O que me parece fundamental - e sem pretender idealizar a revolução guineense, pois que ela vem sendo feita por homens e mulheres e não por anjos - é que valores que se vieram encarnando na dureza da luta, em que o PAIGC se forjou como vanguarda revolucionária do povo, continuam de pé (FREIRE; GUIMARÃES, 2011, p. 57).

Cabe dizer que o estrategista maior, Amílcar Cabral, jamais desprezou os caminhos da diplomacia. Antes de 1963, buscou incessantemente o diálogo com as autoridades portuguesas e, ao longo da luta, o reconhecimento da nova nação no estatuto jurídico internacional. A intransigência daqueles que não cediam aos clamores revoltosos com a iminente perda de tudo que 
havia sido conquistado durante o colonialismo prolongou o tempo de guerra. Enquanto isso, o líder desdobrova-se em viagens visando a angariar os apoios militares, financeiros e humanitários que, juntamente à mobilização da população, garantiram, enfim, a conquista da independência ${ }^{5}$.

Após a libertação de Guiné-Bissau, o regime fascista de Salazar seguiu numa irrefreável perseguição aos líderes revolucionários. Atribui-se à PIDE a responsabilidade pelo assassinato, no dia 20 de janeiro de 1973, de Amílcar Cabral, considerado internacionalmente "o mais brilhante líder da luta por independência nos países africanos colonizados por Portugal” (PEREIRA; VITTORIA, 2012, p. 298). Pouco se pode dizer, porém, desta conspiração, exceto que o líder do PAIGC foi morto em Conacri por elementos infiltrados ou insatisfeitos, até hoje não nominados, em seu próprio Partido.

Em sua primeira visita ao país independente, Paulo Freire tomou imediato conhecimento do projeto das Forças Armadas Revolucionárias do Povo (FARP), que garantia a alfabetização dos guerrilheiros em todas as unidades militares de Guiné-Bissau. Pôde constatar que, nos anos de organização das massas insurgentes, a educação esteve à frente das prioridades de Amílcar Cabral, como mencionado antes. Observou, também, que a unidade da luta, mesmo após o assassinato do líder revolucionário, ainda se dava a partir de seu carisma, reconhecido por Freire no contato com o povo:

E esta compreensão, que é geral na Guiné-Bissau e Cabo Verde, é o resultado da autenticidade do testemunho do grande líder, da maneira como intensamente se experimentou na comunhão com seu povo, sem a qual não poderia ter feito o que fez nem ter sido o que foi e continua a estar sendo. Ninguém é ou continua a estar sendo sozinho. Muito antes de ter sido considerado como "Pai da Nacionalidade", Cabral se fez "Filho do Povo", com ele aprendendo e a ele ensinando, na prática revolucionária (FREIRE; GUIMARÃES, 2011, p. 51).

Quando da descolonização, pois, já se podiam contabilizar dez anos de experiências pedagógicas do PAIGC, a memória delas nas comunidades converteu-se na "matéria prima” para se seguir o projeto de educação

5 Marcos importantes foram a audiência com o Papa Paulo VI, em 1970, e, em 1972, sua intervenção no Conselho de Segurança reunido em Adis-Abeda, quando este apela à ONU para enviar uma missão de visita às regiões libertadas, o que se deu entre 2 e 8 de abril de 1972, contribuindo firmemente para o reconhecimento internacional do PAIGC como representante legítimo do povo da Guiné-Bissau e Cabo Verde (Cf. LOPES, 1983). 
nacional: "Numa perspectiva revolucionária, [...] impõe-se que os alfabetizandos percebam ou aprofundem a percepção de que o fundamental mesmo é fazer história e por ela serem feitos e refeitos e não ler estórias alienantes" (FREIRE; GUIMARÃES, 2011, p. 37). Paulo Freire, em consonância com o ethos revolucionário, propunha a educação como forma de conscientização ou politização visando à superação do colonialismo/colonialidade arraigado/a não somente no sistema social das colônias e ex-colônias, como, em grau máximo, nas subjetividades de sua gente. Por isso, é legítimo pensar que, embebido de Fanon, Freire comungava da crítica decolonial, anos depois, expressa pelo peruano Aníbal Quijano, ao expandir a percepção do quão o controle do colonizador interfere em todas as dimensões da vida do colonizado:

[...] o poder, nesta perspectiva, é uma malha de relações de exploração/dominação/conflito que se configuram entre as pessoas na disputa pelo controle do trabalho, da "natureza", do sexo, da subjetividade e da autoridade. Portanto, o poder não se reduz às "relações de produção", nem à "ordem e autoridade", separadas ou juntas. E a classificação social refere-se aos lugares e aos papéis das gentes no controle do trabalho dos seus recursos (incluindo os da "natureza") e seus produtos; do sexo e seus produtos; da subjetividade e dos seus produtos (antes de tudo o imaginário e o conhecimento); e da autoridade, dos recursos e dos seus produtos (QUIJANO, 2013, p. 46).

Presente no trabalho, no Estado e na produção do conhecimento, o colonizador "imprime sua forma ao conquistado que, introjetando-o, se faz um ser ambíguo” (QUIJANO, 2013, p. 135). A colonialidade do ser, nos termos do movimento intelectual Modernidade/Colonialidade/Decolonialidade, verifica-se, tal como em Memmi, na consciência colonizada (2007), incapaz da autonomia do pensamento, logo, da resistência. O sequestro das consciências mantém, assim, a hegemonia colonial.

A colonialidade do ser poderá vir a ser uma forma possível de teorizar as raízes essenciais das patologias do poder imperial e da persistência da colonialidade. Ela permitirá estabelecer relações entre Ser, espaço e história, que se encontram ausentes das explicações heideggerianas e que também se perderão se se associar o Ser ao Império (MALDONADO-TORRES, 2013, p. 44). 
Resgatar sua subjetividade implica para homens e mulheres colonizados tomar consciência da usurpação e querê-la de volta. O propósito da decolonialidade (descolonialidade) do poder, do saber e do ser, bandeiras do giro decolonial latino-americano, já estava contido, como se percebe, na pedagogia freiriana sob a inspiração de Memmi e Fanon.

Não é, por isso, um episódio fortuito que a crítica decolonial Catherine Walsh (2013) reconheça, no método freiraino de alfabetização de adultos, uma pedagogia decolonial que se desenvolve a partir das categorias de humanização e de libertação e da maneira como estas se articulam em suas dimensões objetivas e subjetivas.

$\mathrm{O}$ intento da descolonização das mentes requer, portanto, a revolução permanente, ponto nevrálgico para Amílcar Cabral e que conduzia, também, a práxis de Paulo Freire na direção da reafricanização das mentalidades. Não havia dúvidas, para Freire, de que a autoconfiança de um povo se ligava, profundamente, à valorização de sua própria cultura e história e exigia o confronto com o modelo colonial de escola:

A educação colonial herdada, de que um dos principais objetivos era a "desafricanização" dos nacionais, discriminadora, mediocremente verbalista, em nada poderia concorrer no sentido da reconstrução nacional, pois para isto não fora constituída. A escola colonial, a primária, a liceal, a técnica, esta separada da anterior, antidemocrática nos seus objetivos, no seu conteúdo, nos seus métodos, divorciada da realidade do país, era, por isso mesmo, uma escola de poucos, para poucos e contra as grandes maiorias (FREIRE; GUIMARÃES, 2011, p. 24).

Tratava-se de caminhar na contramão do sistema educativo herdado do colonialismo, que levou não somente à formação de uma muito reduzida elite, como à formação de uma mentalidade individualista, indiferente socialmente e, ainda, do ponto de vista técnico e profissional, despreparada (MESQUIDA; PEROZA; AKARI, 2014).

Daí o descaso que essa escola [colonialista] necessariamente teria de ter por tudo o que dissesse de perto aos nacionais, chamados de "nativos”. Mais do que descaso, a negação de tudo o que fosse representação mais autêntica da forma de ser dos nacionais: sua história, sua cultura, sua língua. A história dos colonizados "começava” com a chegada dos colonizadores, com sua presença "civilizatória”; a cultura dos coloni- 
zados, expressão de sua forma bárbara de compreender o mundo. Cultura, só a dos colonizadores. A música dos colonizados, seu ritmo, sua dança, seus bailes, a ligeireza de movimentos de seu corpo, sua criatividade em geral, nada disto tinha valor. Tudo isto, quase sempre, tinha de ser reprimido e, em seu lugar posto o gosto da Metrópole, no fundo, o gosto das classes dominantes metropolitanas (FREIRE; GUIMARÃES, 2011, p. 25 - os colchetes são meus).

A pedagogia pós-colonial de Paulo Freire refutava a colonização cogniti$v a$, promovendo as vozes e os saberes emudecidos ao longo do colonialismo. Educador e educando passavam a se reconhecer, ambos, como aprendizes numa relação dialógica em que saberes diversos se encontram. Tal princípio converge com o mais caro na crítica decolonial ao eurocentrismo que, conforme destacou Walter Mignolo (2003), criou arbitrariamente a bipartição entre centros produtores e receptores de conhecimento, sujeitos e objetos do conhecimento. Combatendo a reificação do Outro desde a experiência da alfabetização, Freire preconizava o empenho ainda necessário hoje de desconstrução dos estereótipos que "objetificam” populações inteiras.

Paulo Freire e sua equipe acompanharam o Ministro Mário Cabral em seu intento de fazer desdobrar as mudanças revolucionárias nos planos material e subjetivo. A primeira campanha de alfabetização, planejada em 1975 e iniciada em 1976, com mais de 200 alfabetizadores, organizou os chamados círculos culturais nas áreas rurais, vilarejos e na capital. Se Guiné-Bissau trazia, dos tempos das guerrilhas, o investimento na educação de seus militantes, agora, tratava-se de expandir a educação para todos(as), em prol da reorganização política de uma sociedade recém liberta do jugo colonial.

\section{A língua portuguesa e a reafricanização: paradoxos}

Paulo Freire divergiu de Amílcar, pela primeira vez, em nome de Fanon, quanto à importância da linguagem de um povo. Para o educador brasileiro, mais do que deter uma função instrumental, a "língua da alfabetização" confundia-se com a constituição mesma da identidade daquele que se alfabetiza: "um homem que possui a linguagem possui, em contrapartida, o mundo que essa linguagem expressa e que lhe é implícito” (FANON, 2008, p. 34). Amílcar Cabral defendia, porém, desde o tempo da revolução, o português como a língua da unidade nacional: 
[...] o português (língua) é uma das melhores coisas que os tugas nos deixaram, porque a língua não é prova de nada mais senão um instrumento para os homens se relacionarem uns com os outros: é um instrumento, um meio para falar, para exprimir as realidades da vida e do mundo (CABRAL, 1974, p. 60-61).

Paulo Freire, na prática da alfabetização, constatou, contudo, o paradoxo de se reafricanizar o povo utilizando a língua que os havia desafricanizado. Desde a Pedagogia do Oprimido (1987), o educador vinculava a libertação à capacidade de se enunciar a própria palavra, na sua língua, pois, aquela que se conhece/sente/expressa. Na experiência em Guiné-Bissau, o tema mostrou-se excepcionalmente espinhoso. Paulo Freire, que jamais se pretendeu o autor da campanha de alfabetização em Guiné, mas alguém que vinha “assessorar”, ajudar, no processo protagonizado pelos guineenses, sabia dos desafios a ser enfrentados.

Durante a guerra de libertação conduzida por Amílcar Cabral, é verdadeiro que a alfabetização em português dos militantes serviu eficazmente ao imperativo da mais ágil comunicação. Após a morte do líder, o governo não ousou outro caminho, de modo que não se optou pelo "crioulo" (língua exclusivamente oral), ainda que falado por $45 \%$ dos guineenses. Também, o governo não poderia escolher uma entre as mais de 30 línguas das diversas etnias em Guiné. O fato era que as escolas-piloto de Amílcar Cabral alfabetizavam, desde os inícios de 1960, em português no consenso de que não se queria, tal como anunciado anteriormente, isolar a nação no plano internacional. Talvez, seja prudente assinalar que até mesmo os líderes, em que pese seu intento de descolonizar mentes, haviam sido eles próprios colonizados no idioma português que seguia como a língua oficial do país:

[...] Por que nós, a alfabetização, estávamos a fazê-la em português. Além de ser uma língua desconhecida pela grande maioria da população, as pessoas não entendiam muito bem a razão. Lembro-me de que, uma vez, me disseram: "Mas, afinal, os colonialistas estiveram cá quinhentos anos e não nos fizeram aprender a língua deles. Como é que agora o PAIGC, que lutou contra o colonialismo, vai-nos ensinar o português?!” Eu disse: “Olha, é tão simples como isso: eu sou agrônomo. Estamos a tentar melhorar a nossa agricultura. Nós temos que recorrer a instrumentos, sementes melhoradas, adubos etc., mas 
também vamos recorrer a tratores. Não fomos nós que inventamos o trator. Nós vamos utilizá-lo para abrir os caminhos do desenvolvimento. Ora, a alfabetização é isso mesmo. As nossas línguas são muitas, uma trintena, e não temos a capacidade de fazer a alfabetização em todas as línguas. Vamos utilizar o português (CABRAL apud FREIRE; GUIMARÃES, 2011, p. 214)

Paulo Freire e sua equipe podiam discordar da opção, mas o país não era deles. Não lhes cabia a decisão. Freire aprendia com os dilemas enfrentados e antecipava, na prática, os desafios pós-coloniais.

Nos círculos de cultura tornou-se evidente que os progressos em português [...] como língua do programa de alfabetização era extremamente lento. Essa lentidão deixava claro que o português era completamente alheio às práticas sociais diárias do vilarejo. Os vilarejos não conheciam o português, mesmo na sua forma oral. Os grupos étnicos falam sua língua nativa africana e muitas pessoas, mas não todas, falam crioulo [...]. Para os camponeses, por outro lado, é meramente uma língua estrangeira que não conhecem. Uma forma de código linguístico que é impossível decifrar, e que seria inútil aprender, não tendo aplicação no contexto de suas vidas.

Mas um fenômeno que nos animou ocorreu nos círculos de cultura de Sedengal. Apesar das dificuldades que emergiram na aprendizagem em português, vários participantes gradualmente conseguiram entender e registrar o processo de dividir as palavras em sílabas e de reconstruí-las e aplicaram esta técnica em crioulo. Espontaneamente e inesperadamente, alguns grupos construíram breves histórias em crioulo [...] e escreveram frases na linguagem étnica deles (FREIRE, 1978, p. 41-2. Os colchetes são meus)

Em verdade, a questão nacional posta em xeque pela crítica pós-colonial a desnuda, revelando que a narrativa nacional não podia encontrar validação na realidade na medida em que se dava num "tempo homogêneo vazio” (CHATERJEE, 2004, p. 71), logo, irreal. Se, no exame da formação dos Estados nacionais na Europa, a nação como metarelato fazia sentido, na medida em que a história remetia à ideia de contrato social, criação iluminista, que suporia um acordo entre os cidadãos - também, havia, como para Herder (1995), aquelas nações nascidas sob a inspiração do Volksgeist -, nas ex-colônias, os conflitos eram de outra ordem. 
A ideia-força de solidariedade nacional entendia a substituição, dada a extensão do território, das interações face a face pelo desenvolvimento de uma imaginação que irmanaria aqueles e aquelas que sequer se conhecem, nas palavras de Benedict Anderson (1998), por uma comunidade imaginada. Nas ex-colônias, por sua vez, esta teoria era posta em xeque diante do dilema do que poderia unir, como compatriotas, grupos de existências material e subjetiva, reconhecimentos e status tão díspares, como negros, negros "assimilados”, brancos, os membros de múltiplas e, às vezes, antagônicas tribos, a população rural e os citadinos, os muçulmanos, os cristãos e aqueles de inúmeras outras religiões.

Os territórios forjados em países, ora independentes, nasciam, na África, da violência do colonialismo, das lutas sangrentas e dos massacres que expulsaram os colonos e seus herdeiros apenas na segunda metade do século $\mathrm{XX}$. Nos longos anos de guerrilhas, a população nativa se dividiu nas estratégias de enfrentamento e foram criadas hierarquias e não menos oposições entre os revolucionários. Após a independência, as negociações em torno de um projeto nacional se viram interrogadas pelos sentidos em disputa de questões como a modernidade, a modernização, o progresso e o desenvolvimento. Tais ideias-força estiveram, até então, a serviço do colonialismo e traziam as memórias dos etnocídios e da deculturação. Também, implicavam o consenso acerca do "novo homem", que seja este angolano, moçambicano, guineense. Quaisquer tentativas de se "essencializar” a nação esbarravam com as tensões e hibridismos de um mundo "pós-moderno", a saber, em que todas as identidades fixas haviam sido desalojadas. O projeto nacional parecia, assim, anunciar uma espécie de violência que negligenciava as temporalidades heterogêneas e conflituosas nascidas dos contatos em diferentes níveis e dimensões entre a diversidade das tradições locais e o "mundo", quer o bloco socialista, quer o capitalismo transnacional tornado hegemônico.

Mais uma vez, Paulo Freire vivencia a questão pós-colonial somente alguns anos depois sitematizada e nominada: a proliferação de modernidades alternativas que não se submetiam a uma narrativa monolítica da modernidade. Os híbridos pós-coloniais, África e Guiné-Bissau, serviram a Freire de "professores" no desterro dotando-lhe, nos termos de Theodor Adorno, em Mínima Moralia (2008), de uma "perspectiva alterada”. Conforme Paz, “[...] só o desenraizamento permitiu-nos recobrar nossa porção de realidade. A distância foi a condição da descoberta” (1976, p. 129). 
Freire descobriu, na África, que a alfabetização requeria a negociação entre as temporalidades multidimensionais ou modernidades entrelaçadas, nos termos pós-coloniais. Nessa perspectiva, requeria a quebra de qualquer suposto universalista (ainda que este fosse uma língua nacional) mediante esforços de tradução. Seu método, radicalmente afetivo, requeria a identificação de alfabetizadores e alfabetizandos com o "mundo cultural" contido em cada vocábulo a ser conhecido.

$\mathrm{Na}$ tradução, os significados somente se delineiam provisória e temporariamente, performaticamente, na medida em que respondem às interpelações históricas e socioculturais (ARROJO, 1995). Alfabetizar sem "colonizar mentes” em Guiné-Bissau implicava o engajamento com a reafricanização da África. O problema enfrentado na campanha de alfabetização nacional não deve ser identificado no método freiriano que seguia a diretriz da construção escrita da "palavra desalienadora". O nó górdio encontrado era precisamente o desafio das epistemologias pós-coloniais (e decoloniais) em torno das quais alguns intelectuais contemporâneos produzem suas reflexões. Mas, dificilmente, tais reflexões se dariam da forma como se dão se não pelo acúmulo de conhecimento gerado nas redes que enlaçaram os intelectuais diaspóricos e periféricos no mundo, dentre eles Paulo Freire, Amílcar Cabral, Frantz Fanon, Albert Memmi.

\section{Considerações Finais}

Stuart Hall, no capítulo “Quando foi o 'pós-colonial'?”, de Da Diáspora (2009), sabe que o pós-colonial diz respeito a uma longa transição que se inicia com o colonialismo, logo, com as lutas anticoloniais. Os conflitos entre colonizadores e colonizados produzem algo como um terceiro espaço (MIGNOLO, 2003; BHABHA, 2007), de maneira que a experiência colonial inaugura novos mundos, quer nos territórios que sofreram as invasões quer nos locais de onde partiram os invasores, impondo, como se tentou demonstrar ao longo do artigo, as temporalidades distintas, todas elas presentes e concretas, reunidas arbitrariamente no metarelato da modernidade hegemônica. Nada há, contudo, de fixo nesses novos mundos. O pós-colonial enxergaria, enfim, no lugar da modernidade monolítica, uma pluralidade de possibilidades de existência sobredeterminadas, suturadas, suplementares, contraditórias. 
A questão pós-colonial invalidou as dicotomias que, na racionalidade cartesiana, organizaram a vida (alma/corpo; razão/emoção; homem/mulher; civilização/barbárie; Eu/Outro). Coube aos produtores de conhecimento a partir das colônias ou da periferia desafiar com argumentos concretos e mais potentes o que os pós-modernos europeus haviam anunciado sob a influência do pós-estruturalismo derridiano: as diferenças não são absolutas nem estáticas, mas se realizam processual e relacionalmente, sobretudo, na invenção da linguagem, que, por sua vez, inscreve-se no mundo real. Eis que os colonizados digeriram antrofagicamente o "espólio" do colonizador (também, sua língua), ao mesmo tempo em que os colonizados foram coautores da história dos colonizadores, a começar por suas riquezas e muitos "inventos”, trazidos mediante a violência da usurpação.

O pós-colonial nasce, assim, do entrelaçamento tenso das histórias e das culturas e propõe o entre-lugar (SANTIAGO, 2006; BHABHA, 2007), que é processo, movimento, acontecimento. Cada pessoa é tornada, no entre-lugar, um "tradutor”. Homi Bhabha (2007) sugere a mímeses, ironia e paródia como ato de tradução/transgressão. Portanto, se a alfabetização pós-colonial é aquela a produzir tradutores descolonizados e competentes, falamos, também, da produção da "rebeldia” e da desobediência epistêmica. Efetivamente, nenhuma língua corre o risco de ser assimilada completa e acriticamente porque ela não existe em "substância”, mas é relação e movimento, deslocamentos e trânsitos, entrelugares, viva que está.

Paulo Freire, o alfabetizador da palavra-vida, da letra-luta, da leitura que ressignifica o mundo, pôde ser, em nossa argumentação, antes do nome existir, um pensador decolonial (descolonizador). Talvez, revisitá-lo à luz das questões contemporâneas ajude-nos a facilitar a "tradução" e criar "pontes" entre interpretações do mundo. Em tempos de comunicação violenta (ou não-comunicação), parece relevante refazer caminhos que levaram o pensamento, noutras "estruturas de sentimentos", a se refazer cotidiana e teimosamente, avistando chances de reconhecimento e de inclusão das diferenças num "universal” de novo tipo, ampliado, diverso, quiçá, como pensou Edward Said (2007), de um humanismo crítico e ético. 


\section{Referências bibliográficas}

ADORNO, Theodor. (2008), Mínima Moralia. Reflexões a partir da vida lesada. São Paulo: Azougue.

ANDERSON, Benedict R. (1998), Comunidades imaginadas: reflexões sobre a origem e a difusão do nacionalismo. São Paulo: Companhia das Letras.

ARROJO, Rosemary. (1995), Tradução, Desconstrução e Psicanálise. Rio de Janeiro: Imago.

BENJAMIN, Walter. (1985), “Teses sobre filosofia da história”. In: KOTHE, Flávio R. (Org.). Sociologia. São Paulo: Ática. pp. 153-164.

BHABHA, Homi. (2007), O local da cultura. Belo Horizonte: Editora UFMG.

CABRAL, Amílcar. (1974), PAIGC: unidade e luta. Lisboa: Nova Aurora.

CHATERJEE, Partha. (2004), “A Nação em Tempo Heterogêneo”. In: CHATTERJEE, Partha. Colonialismo, Modernidade e Política. Salvador: EDUFBA; CEAO. pp. 67-95.

DERRIDA, Jacques. (1991), Margens da filosofia. Campinas: Papirus.

FANON, Frantz. (2008), Pele negra, máscaras brancas. Salvador: EDUFBA.

FREIRE, Paulo. (1978), Cartas à Guiné-Bissau: registros de uma experiência em processo. Rio de Janeiro: Paz e Terra.

FREIRE, Paulo. (1992), Pedagogia da esperança. São Paulo: Paz e Terra.

FREIRE, Paulo. (1987), Pedagogia do oprimido. Rio de Janeiro: Paz e Terra.

FREIRE, Paulo; GUIMARÃES, Sérgio. (2011), A África ensinando a gente. São Paulo: Paz e Terra.

GADOTTI, Moacir (Org.). (1996), Paulo Freire: uma biobibliografia. São Paulo: Cortez Editora; Instituto Paulo Freire.

GASPARINI, Pablo. (2011), "Sobre a perda da grandiloquência na literatura hispano-americana pós-noventa: notas sobre a des-representação do exílio em Lembel e Bolaño”. Estudos de Literatura Brasileira Contemporânea, n. 38, pp. 97-107.

GUAMAN POMA de AYALA, Felipe. (1980), Nueva crónica y Buen gobierno. Tomo II. Transcripción, prólogo, notas y cronología. Caracas: Biblioteca Ayacucho.

HALL, Stuart. (2009), Da diáspora. Identidades e mediações culturais. Belo Horizonte: Editora UFMG.

HERDER, Johann Gottfried. (1995), Também uma filosofia da historia para formação da humanidade: uma contribuição a muitas contribuições do século. Lisboa: Ed. Antígona. 
LOPES, Carlos. (1983), Ethnie et rapports de pouvoir en Guinée-Bissau. Genebra: Institut Universitaire d'Études du Développement.

MALDONADO-TORRES, Nelson. (2013), "A topologia do ser e a geopolítica do conhecimento: modernidade, império e colonialidade”. In: SANTOS, Boaventura de Souza; MENESES, Maria Paula (Org.). Epistemologias do Sul. São Paulo: Cortez. pp. 337-382.

MEMMI, Albert. (2007), Retrato do colonizado precedido de Retrato do colonizador. Rio de Janeiro: Civilização Brasileira.

MESQUIDA, Peri; PEROZA, Juliano; AKARI, Abdeljalil. (2014), "A contribuição de Paulo Freire à educação na África: uma proposta de descolonização da escola”. Educação \& Sociedade, v. 35, n. 126, pp. 95-110. Disponível em: http://www.scielo.br/pdf/es/v35n126/06.pdf. Acesso em: 31 jan. 2018.

MIGNOLO, Walter. (2003), Histórias locais. Projetos globais. Colonialidade, saberes subalternos e pensamento liminar. Belo Horizonte: Ed. da UFMG.

ORTIZ, Renato. (1995), "Frantz Fanon: Um itinerário político e intelectual”. Revista Idéias, v. 2, n. 1, pp. 425-442.

PAZ, Octavio. (1976), Signos em rotação. São Paulo: Perspectiva.

PEREIRA, Amílcar Araújo; VITTORIA, Paolo. (2012), "A luta pela descolonização e as experiências de alfabetização na Guiné-Bissau: Amílcar Cabral e Paulo Freire”. Revista Estudos Históricos, v. 25, n. 50, pp. 291-311.

QUIJANO, Aníbal. (2013), “Colonialidade do poder e classificação social”. In: SANTOS, Boaventura de Souza; MENESES, Maria Paula (org.). Epistemologias do Sul. São Paulo: Cortez. pp. 84-130.

RICHARD, Nelly. (2002), Intervenções críticas: arte, cultura, gênero e política. Belo Horizonte: UFMG.

ROMÃO, José Estáquio; GADOTTI, Moacir. (2012), Paulo Freire e Amílcar Cabral: a descolonização das mentes. São Paulo: Instituto Paulo Freire.

SAID, Edward. (2007), Humanismo e crítica democrática. São Paulo: Companhia das Letras.

SANTIAGO, Silviano. (2006), As raízes e o labirinto da América Latina. Rio de Janeiro: Rocco.

SAVIANI, Demerval. (1984), Escola e democracia. São Paulo: Mercado de Letras.

WALSH, Catherine. (2013), Pedagogías decoloniales: Prácticas insurgentes de resistir, (re)existir y (re)vivir. Quito: Ediciones Abya - Yala. Disponível em: $\quad$ http://www.reduii.org/cii/sites/default/files/field/doc/Catherine\%20 Walsh\%20-\%20Pedagog\%C3\%ADas\%20Decoloniales.pdf. Acesso em: 31 jan. 2018. 
WILLIAMS, Raymond. (2011), Cultura e materialismo. São Paulo: Ed. UNESP. ZANELLA, José Luiz. (2010), “Considerações sobre a Filosofia da Educação de Paulo Freire e o Marxismo”. Quaestio. Revista de Estudos em Educação, v. 9 , n. 1, pp. 101-122. 


\title{
A Trajetória Artístico-intelectual Glauberiana: Da Estética da Fome à Eztetyka do Sonho
}

\author{
Irma Maria Viana da Silva*
}

\section{RESUMO}

Partindo da hipótese de que Glauber radicaliza sua proposta de arte revolucionária, abordarei aqui a passagem, na trajetória artístico-intelectual (e política) glauberiana, da posição adotada no manifesto Uma Estética da Fome (2004 [1965]) para a perspectiva estético-teórica traçada na Eztetyka do Sonho (2004 [1971]), conferência realizada em Congresso na Columbia University. Rocha, além de cineasta de prestígio internacional, foi um dos principais teóricos do Cinema Novo e o estudo aqui de sua trajetória artístico-intelectual não pode separar sua prática cinematográfica e política de sua teoria estética, entendida como ética. Assim, a análise da passagem de um manifesto a outro nos permite observar os diversos sentidos da arte revolucionária teorizados por Glauber, suas transformações e tentativas de aplicação prática, sob uma perspectiva descolonizadora e do ponto de vista da Crítica Pós-Colonial. Palavras-chave: Arte Política. Glauber Rocha. Crítica Pós-Colonial.

\footnotetext{
Professora colaboradora do Programa de Pós-Graduação em Ciências Sociais Universidade
} Federal da Bahia. 


\begin{abstract}
THE GLAUBERIAN ARTISTIC-INTELLECTUAL TRAJECTORY: FROM AESTHETICS OF HUNGER TO EZTETYKA OF THE DREAM
\end{abstract}

Starting from the hypothesis that Glauber Rocha radicalizes his proposal of revolutionary art, I will approach here the passage in his artistic-intellectual and political trajectory from the position adopted in the Aesthetic of Hunger (2004 [1965]) to the aesthetic-theoretical perspective outlined in Eztetyka do Sonho (1971), in a Conference at Columbia University. Rocha as an international prestige filmmaker, was one of the main theorists of Cinema Novo. So this study on his artistic-intellectual trajectory can not separate his cinematographic and political practice from his aesthetic theory, understood as ethics. Thus, the analysis of the passage from one manifesto to another allows us to observe the various senses of revolutionary art theorized by him, its transformations and attempts to practical applications, from a decolonizing perspective and from the point of view of the Postcolonialism.

Keywords: Political Art. Glauber Rocha. Postcolonial Criticism.

\title{
Introdução
}

Foi o mundo moderno que fez surgir o conceito de razão, e foi a partir do momento em que o sentido da palavra razão foi fixado que a razão se tornou desracionalizável.

(MORIN, 2002, p. 9)

Analiso aqui os pressupostos teórico-estéticos esboçados por Glauber Rocha no manifesto do Cinema Novo (movimento organizado por Glauber no intuito de fundar um novo modo de fazer cinema em oposição ao modelo hollywoodiano hegemônico), Uma Estética da Fome, escrito em 1965 e apresentado no Seminário Cinemas do Terceiro Mundo, em Gênova, Itália, e a passagem, na sua trajetória artístico-intelectual, para a perspectiva traçada na Eztetyka do Sonho, conferência realizada em Congresso na Columbia University, em Nova York, em 1971, introduzida por ele, em sua apresentação oral, da seguinte forma:

No “Seminário do Terceiro Mundo” realizado em Gênova, Itália, 1965, apresentei, a propósito do Cinema Novo brasileiro, "A Estética da Fome”. Esta comunicação situava o artista do Terceiro Mundo diante das potências colonizadoras: apenas uma estética da violência poderia integrar um significado revolucionário em nossas lutas de libertação. [...] O Maio 
francês aconteceu no momento em que estudantes e intelectuais manifestavam no Brasil seu protesto contra o regime militar de 1964. "Terra em Transe”, 1966, um manifesto prático da estética da fome, sofreu no Brasil críticas intolerantes da direita e de grupos sectários de esquerda. [...] Este Congresso é outra oportunidade que tenho para desenvolver algumas ideias a respeito de arte e revolução. (ROCHA, 2004, p. 248)

Um ponto fundamental a ser considerado diz respeito à questão do seu engajamento/distanciamento crítico em relação ao ideário político cultural que caracterizou, no Brasil, a efervescente década de 1960 - que constitui os limites da presente análise. É importante observar ainda que um intelectual não se faz sozinho e sem trabalho intencional, mas este se constitui (enquanto tal) ou se representa, como quer Said (2005), em relação a um dado contexto sociointelectual, com o qual necessariamente vai dialogar.

O Cinema Novo foi um movimento surgido no início dos anos 1960 em oposição ao "cinema industrial”, configurado na política cinematográfica dos grandes estúdios. Este movimento encontra em Glauber Rocha sua liderança. Como movimento cultural em oposição ao cinema de indústria, o Cinema Novo se insere numa ascensão sociocultural de dimensão internacional. A precariedade instrumental dos jovens cineastas que formaram o movimento foi um fator importante para a concepção estética de um novo cinema. Assim como a independência da produção possibilitou uma crítica da realidade brasileira, especialmente do modo de produção fílmica, em favor de uma nova linguagem, contra o colonialismo cultural da política dos grandes estúdios (hegemônica), voltada, do ponto de vista dos cinemanovistas, para interesses imperialistas.

Cabe observar ainda que a geração da qual fez parte Glauber Rocha foi fortemente marcada pela ditadura militar e pela ideologia nacional desenvolvimentista dos anos JK. Crítico a essas duas "situações históricas”, Glauber volta-se para a questão da "fome" e da "violência” que caracteriza a sociedade "subdesenvolvida".

A análise da passagem do manifesto do Cinema Novo, de Uma Estética da Fome para a Eztetyka do Sonho, nos permite observar os diversos sentidos da arte revolucionária (teorizada pelo Centro Popular de Cultura - CPC ) empregados por Glauber em sua trajetória artístico-intelectual, suas transformações e tentativas de aplicação prática, sob uma perspectiva crítica do colonialismo que pode ser aproximada da chamada Crítica Pós-Colonial, 
perspectiva esta radicalizada naquele segundo momento, em que escreveu, na Eztetyka do Sonho, "a ruptura com os racionalismos colonizadores é a única saída” (ROCHA, 2004, p. 250).

$\mathrm{Na}$ passagem da estética da fome e da violência para a estética do sonho, Rocha foi, em tese, reformulando seu conceito de arte revolucionária, cujos pressupostos foram inspirados pelo teatro político de Brecht:

Eu sempre me interessei por um cinema épico e por isso sempre me interessei também por essas formas populares de representação. Depois me dei conta das semelhanças - claro, indiretas - que existiam entre esse tipo de estruturas teatrais e musicais populares e o trabalho de Brecht. [...] Brecht, de fato, se inspirou nos modos populares e os utilizou para uma dramaturgia política. (ROCHA, 2004, p. 155).

Com isso Glauber se volta para uma dimensão crítica e reflexiva do pensamento e das artes - e não simplesmente adere (como fez o CPC, de forma acrítica) à concepção instrumental da cultura, própria da sociedade capitalista -, o que o aproxima da noção de cultura concebida por Gramsci sob o prisma da hegemonia. Segundo Marilena Chaui, Gramsci foi além da crítica da ideologia como exercício da dominação e propôs o conceito de hegemonia para designar "a luta no interior da sociedade política com o objetivo de operar mudanças nas ideias, nos valores, no comportamento e nas práticas visando à consciência dos explorados e dominados. Donde a importância que conferiu à cultura” (CHAUI, 1994, p. 10).

Porém, como Glauber, Gramsci, podemos dizer, propõe, de acordo com Chaui (1994), uma mudança na e da cultura. Não se trata, não obstante, de instrumentalizar a cultura para a luta política, como as esquerdas brasileiras tenderam (e tendem) a interpretar a posição de Gramsci, especialmente o CPC (grupo ao qual Glauber de contrapôs), para quem a luta pela hegemonia transformou-se em atuação pedagógica (ensinar a verdade às massas).

Com relação à questão da produção da verdade ${ }^{1}$, coloca Glauber Rocha, no manifesto Uma Estética da Fome, apresentado em Congresso sobre o Cinema do Terceiro Mundo, em Gênova, na Itália, em 1965:

1 Em certo sentido, Glauber aproxima-se ainda da concepção foucaultiana (FOUCAULT, 1979), em que o problema político essencial do intelectual não é mais, ou apenas, o de criticar os conteúdos ideológicos que estariam ligados à ciência ou fazer com que a sua prática seja acompanhada por uma ideologia justa, mas saber se é possível construir uma nova política da verdade. 
Eis - fundamentalmente - a situação das Artes no Brasil diante do mundo: até hoje, somente mentiras elaboradas da verdade (os exotismos formais que vulgarizam problemas sociais) conseguiram se comunicar em termos quantitativos, provocando uma série de equívocos que não terminam nos limites da Arte mas contaminam sobretudo o terreno geral do político" (ROCHA, 2004, p. 63).

Assim, acreditamos que a abordagem da trajetória artístico-intelectual glauberiana possa lançar alguma luz sobre os conflitos ideológicos e lutas políticas no campo cultural na década de 1960, dado que Glauber Rocha, além de cineasta de prestígio internacional, crítico e escritor, foi o principal teórico do movimento Cinema Novo, atuando como um protagonista político ativo no campo cinematográfico e cultural.

\section{Por uma Estética da Violência}

No primeiro manifesto do Cinema Novo, Glauber lançou a ideia da estética da fome como uma estética da violência - um modo de expressão possível da parte do colonizado, para que o colonizador compreenda a sua existência, como dita o método fanoniano (FANON, 2005). Enquanto na Eztetyka do Sonho, defendeu o irracionalismo na arte de vanguarda (contra a razão opressora do colonizador) como única arma do artista intelectual revolucionário, terceiro mundista.

O manifesto Uma Estética da Fome foi escrito em concomitância com um amplo debate acerca da libertação nacional dos povos colonizados. Faz referência explícita à obra Os Condenados da Terra, de Frantz Fanon (2005), para quem a violência é o elo fundador do colonialismo. Considerada a mais célebre das intervenções públicas do cineasta no exterior, traduzida e publicada rapidamente na Europa, nos EUA e na América Latina, representa uma tentativa de Glauber de defender o novo cinema latino-americano como dos mais originais, no bojo do movimento dos novos cinemas surgidos no pós-guerra. O cinema Novo era assim concebido por Glauber Rocha como vanguarda das vanguardas, tanto das brasileiras dos anos 1960 (REIS, 2006), quanto das vanguardas cinematográficas europeias, a exemplo do Neorrealismo, que aparece na segunda metade dos anos 1950, na Itália, e, em seguida, no final da década de 1950 e início dos anos 1960, surgem, na França, a Nouvelle Vague, na Inglaterra, o Free Cinema e nos Estados Unidos o New 
American Cinema. Ante estes movimentos, já que participava de um Congresso de Cinema, na Europa, na seção que abordava o Nuevo Cine Latinoamericano, Glauber procurou situar, em seu manifesto estético-teórico, o cinema novo brasileiro:

\begin{abstract}
Aí reside a trágica originalidade do Cinema Novo diante do cinema mundial: nossa originalidade é nossa fome e nossa maior miséria é que esta fome, sendo sentida, não é compreendida. Nós [cinemanovistas] compreendemos essa fome que o europeu e o Brasileiro na maioria não entendeu. Para o europeu é um estranho surrealismo tropical. Para o Brasileiro é uma vergonha nacional.
\end{abstract}

Glauber procurou mostrar, entre outras coisas - assim como havia discutido no Deus e o Diabo na Terra do Sol, de 1964, e voltou a mostrar no Dragão da Maldade Contra o Santo Guerreiro, de 1969 -, que a violência "rústica" de personagens como Corisco, Coirana, Antônio das Mortes ou o Santo Sebastião (alegorias de personagens históricos, como Lampião, Antônio Conselheiro etc.), tida pelo europeu como “primitiva”, não é pré-civilizatória, ou seja, não se trata de um fenômeno anterior à civilização, mas seu excedente. O objetivo ali (nos filmes do cinema novo) não era de expor um estado pré-capitalista, mas sim suas consequências. Da mesma forma se tratava, em primeiro lugar, especialmente nos filmes de Glauber Rocha, de realizar a crítica do chamado "processo civilizatório brasileiro".

Sendo assim e tendo mudado, na última hora, o tema de sua Comunicação (da mesma forma que sempre modifica o roteiro de suas produções na filmagem, que por sua vez é reconstruída pela montagem), avisa Glauber, não sem ironia, ao iniciar sua fala no Seminário sobre o Cinema, na sessão Cinemas do Terceiro Mundo, em Gênova, Itália, em 1965:

Dispensando a introdução informativa que se transformou na característica geral das discussões sobre a América Latina, prefiro situar as relações entre nossa cultura e a cultura civilizada em termos menos reduzidos do que aqueles que também caracterizam a análise do observador europeu. (ROCHA, 2004 [1965], p. 63)

Ou seja, começa esclarecendo o lugar de onde está falando, e com isso distancia seu ponto de vista daquele do crítico europeu, logo de início. Ele, que fora convidado para falar sobre o cinema novo brasileiro, caracterizou- 
-o sim (num texto que acabou por se tornar $o$ manifesto dos novos cinemas latino-americanos) em termos não de um estilo, mas de uma prática (política) e de estética própria do cineasta latino.

Glauber, profundo conhecedor do cinema (antes de tronar-se cineasta foi, muito jovem, cinéfilo, escritor, teórico e crítico), ambicionava, com o movimento Cinema Novo, dar a sua contribuição prática (e política) para a história do cinema mundial, traçada por ele no livro O Século do Cinema². E, assim, definiu o cinema novo: "onde houver um cineasta disposto a enfrentar o comercialismo, a exploração, a pornografia, o tecnicismo, aí haverá um germe do cinema novo [...] onde houver um cineasta pronto a pôr seu cinema e sua profissão a serviço das causas importantes de seu tempo, aí haverá um germe do cinema novo" (ROCHA, 2004, p. 67), declarando ao final de sua fala no Congresso na Itália. Mas principia, como visto acima, já fazendo a crítica da crítica europeia acerca dos novos cinemas latinos. E passa então a expor o significado da estética da fome: "somente uma cultura da fome, minando suas próprias estruturas, pode superar-se qualitativamente e a mais nobre manifestação cultural da fome é a violência” (ROCHA, 2004, p. 63).

Deste modo, Glauber declara que uma estética da fome é necessariamente uma estética da violência, que "antes de ser primitiva”, como o europeu vê a arte brasileira e latino-americana, é "revolucionária”, na medida em que "o comportamento exato de um faminto é a violência, e essa violência não é primitivismo" (ROCHA, 2004, p. 66) - este é o primeiro ponto a ser esclarecido por Glauber em sua Estética da Fome, já que os processos de criação artística do mundo subdesenvolvido só interessam ao observador europeu na medida em que satisfazem sua nostalgia do primitivismo.

Em segundo lugar, Glauber coloca que essa violência, assumida como arma política no manifesto do Cinema Novo, "não está incorporada ao ódio" - símbolo do ressentimento (dos oprimidos), contra o qual também se colocara Nietzsche (1988) -, mas ao amor.

O amor que essa violência encerra é tão brutal quanto a própria violência, porque não é um amor de complacência ou de contemplação, mas um amor de ação e transformação. (ROCHA, 2004, p. 66)

2 Conjunto de artigos publicados em jornais e revistas na época e reunidos em 1985, no livro O Século do Cinema, publicado pela EMBRAFILME. 
Associa a violência ao amor porque essa violência, reivindicada em nome dos oprimidos, seria, como o amor, na perspectiva glauberiana, algo transcendental, ou uma força capaz de transformar, de revolucionar. Por essa razão é também posta a serviço de sua crítica da moral e da ordem social vigente, por meio de uma concepção revisionista da arte revolucionária, aplicada de diversas formas nos filmes e teorizada de diferentes perspectivas nos manifestos, de acordo com as novas circunstâncias.

Assim, o sentido atribuído ao amor, como uma força de ação e transformação, no manifesto estética da violência, como também é conhecido, pode ser melhor compreendido por meio de uma aproximação da noção de amor estudada pelo antropólogo francês Edgar Morin:

A questão da selvageria do desejo e da fascinação do amor se relaciona à ordem social. Mas é extremamente notável que o desejo e o amor ultrapassem, transgridam normas, regras e interditos... O amor, mesmo que decorrente de um desenvolvimento cultural e social, não obedece à ordem social: quando aparece, ignora barreiras, despedaça-se nelas ou simplesmente as rompe. (MORIN, 2002, p. 23).

Este era o objetivo do movimento cinema novo (naquelas circunstâncias, no momento de renascimento), qual seja: de transformar a realidade, em última instância, buscando antes atingir (ao expor) as consequências mais profundas da miséria social e da fome, que estavam inconscientes, para trazê-las à consciência. Logo, a meta era conscientizar, não no sentido tradicional, aquele tomado pelos isebianos e cepecistas, de levar a consciência do intelectual ao povo, mas através do choque - empregado como método, segundo fora utilizado também pelo teatro épico e político de Bertold Brecht (CHIARINI, 1967).

A mulher, símbolo do inconsciente e, ao mesmo tempo, de certa razão prática, posto que "em Barravento, Deus e o Diabo, e também Terra em Transe, as mulheres têm consciência do que se passa, consciência da história” (ROCHA, 2004, p. 115), é, nos filmes de Glauber e dos seus pares cinemanovistas, a principal representante desse amor, não romântico (não no sentido burguês adotado pelo modelo hollywoodiano de cinema, contra o qual se voltava o cinema novo), já que exerce um papel transgressor. Por esta razão, segundo Glauber,

O Cinema Novo não fez melodramas: as mulheres do Cinema Novo sempre foram seres em busca de uma saída possível para o amor, dada 
a impossibilidade de amar com fome: a mulher protótipo, a de Porto das Caixas, mata o marido; Rosa vai ao crime para salvar Manoel e amá-lo em outras circunstâncias; a moça do padre precisa romper a batina para ganhar um novo homem [...]. (ROCHA, 2004, p. 66).

Afinal, Glauber, em suas colocações teóricas, evoca a violência como método e, na Estética da Fome, a associa ao amor em oposição ao ódio, representante do ressentimento, condenado por Nietzsche (1988) em sua crítica da moral burguesa, que exerceu clara influência sobre a crítica glauberiana das ideologias tipicamente burguesas, como o amor romântico e o humanismo.

Aproximando as considerações sobre o amor do antropólogo francês Edgar Morin, proferidas na Conferência “O Complexo de Amor”, pronunciada no Colóquio "Palavras de Amor”, em Grenoble, em março de 1990, podemos dizer que a estética da fome, aplicada no Terra em Transe, não é apenas uma estética da violência, mas é, também, uma estética do amor, assim como revelado por Edgar Morin “como o ápice mais perfeito da loucura e da sabedoria, ou seja, que no amor, sabedoria e loucura não apenas são inseparáveis, mas se interpenetram mutuamente” (MORIN, 2002, p. 9).

De fato, está presente no Terra em Transe (em que procura atualizar sua estética da fome) a questão da relação, mais do que isso, da imbricação, da não separação do amor, da loucura e da poesia (sabedoria) na figura de Paulo Martins, que, por fim, confessa: eu recuso a certeza, a lógica, o equilíbrio, prefiro a loucura. Na poética glauberiana (porventura, na vida de Glauber), assim como na poesia de Paulo Martins, loucura e sabedoria se misturam: “Todos vão dizer que sempre fui um louco, um romântico, um anarquista. (...) A minha loucura é a minha consciência e ela está aqui, na hora da verdade, no momento da decisão, na luta, mesmo na certeza da morte" (Terra em Transe, Brasil, 1967).

A revolução como tomada de consciência ainda está presente no que Glauber considera como um manifesto prático da estética da fome, que é o Terra em Transe. Conquanto, nesse filme, o poeta Paulo Martins já apresentasse sintomas de desrazão, rumo à estética do sonho, foi, todavia, no Der Leone Have Sept Cabeças, manifesto prático (como Glauber classifica sua obra artística) do Cine Tricontinental, que se deu a passagem, por assim dizer, da consciência ao mito. Não sem propósito, pois, como disse Morin, num determinado momento histórico, “a poesia é liberada do mito 
e da razão, mas contém em si sua união”, e, mais importante, no caso do personagem Paulo Martins, demonstra que "o estado poético nos transporta através da loucura e da sabedoria, e para além deles” (MORIN, 2002, p. 9).

Outro ponto importante ressaltado por Glauber na Estética da Fome é de que o Cinema Novo não poderia desenvolver-se apartado dos problemas políticos/econômicos do continente Latino-Americano, na medida em que o Cinema Novo era considerado por ele "um fenômeno dos povos colonizados e não uma entidade privilegiada do Brasil” (ROCHA, 2004, p. 67). Pois a integração econômica e cultural do cinema novo, buscada naquele momento, dependia, ainda segundo ele, da libertação da América Latina, para a qual o movimento Cinema Novo deveria contribuir, ao menos no campo cultural, a partir da revolução cinematográfica levada a cabo pelo movimento Cinema Novo na estrutura de produção fílmica, no campo econômico e traçada na Estética da Fome como um projeto a nível continental, depois será Tricontinental. Na visão de Glauber Rocha: "não é um filme, mas um conjunto de filmes em evolução que dará, por fim, ao público, a consciência de sua existência” (ROCHA, 2004, p. 65). Só assim, o movimento cinemanovista seria capaz de tirar o cinema do raquitismo filosófico e da impotência imposta pela tarja subdesenvolvimentista, fruto do processo colonizador.

O problema internacional da América Latina é ainda um caso de mudança de colonizadores, sendo que uma liberdade possível estará ainda por muito tempo em função de uma nova dependência. [...] Esse condicionamento econômico e político nos levou ao raquitismo filosófico e à impotência, que, às vezes inconsciente, às vezes não, geram no primeiro caso a esterilidade e no segundo a histeria. (ROCHA, 2004, p. 64).

Assim, o principal objetivo (no campo da política das artes e da cultura) do manifesto do Cinema Novo, Uma Estética da Fome, era de potencializar, com todas as suas particularidades, o cinema latino-americano e projetá-lo internacionalmente (projetando também, no seu bojo, a diversidade cultural do continente), a despeito de, e, por isso mesmo, enfrentando seu subdesenvolvimento.

Empenhado, naquele momento, em afirmar um programa para o cinema brasileiro, postura que se exprime em sua típica linguagem de manifesto 
(inspirada nas artes de vanguarda - como classifica o Cinema Novo), assim finaliza sua Estética da Fome:

O cinema novo é um projeto que se realiza na política da fome, e sofre, por isso mesmo, todas as fraquezas consequentes de sua existência. Não temos por isso maiores pontos de contato com o cinema mundial. (ROCHA, 2004, p. 67).

Desse modo, Glauber conclui sua fala enfatizando o que já havia colocado no início do manifesto Uma Estética da Fome, ou seja, a distância entre o cinema novo latino-americano e o cinema europeu, e não as influências como era o esperado.

Pois o principal problema político do Cinema Novo, como proclamavam as vanguardas artísticas e políticas brasileiras dos anos 1960 (REIS, 2006), estava atrelado ao reconhecimento de um estado de subdesenvolvimento cultural, que não podia ser separado do problema econômico, nos países da América Latina. No artigo Teoria e Pratica do Cinema Latino Americano, ainda voltado para a questão do mercado interno, principalmente da distribuição (sempre obcecado por essa etapa da produção fílmica, controlada pela indústria cinematográfica norte-americana), Rocha assim colocou a questão:

Da teoria à prática existem contradições econômicas e políticas. Como todas as indústrias latinas, o cinema está controlado pelos americanos. Se a produção ainda é livre, a distribuição é americana, como em todas as partes do mundo capitalista. Uma produção sem distribuição é fatalmente destinada à falência. (ROCHA, 2004, p. 83).

Diante dessas circunstâncias, para projetar o cinema novo como "a mais importante manifestação de cultura latino-americana” (ROCHA, 2004, p. 86), como a "vanguarda das vanguardas", seria imprescindível que os cinemanovistas se empenhassem em exercerem, eles próprios, as funções de produtores, diretores e distribuidores, a exemplo da DIFILM, constituída e mantida por produtores e cineastas do grupo do cinema novo brasileiro (até 1967, quando fora dissolvida pela ditadura militar). Esta distribuidora independente, assumindo uma "atitude política no campo da cultura e da economia” (ROCHA, 2004, p. 85), revolucionou o mercado cultural, de acordo com Glauber, criando, por extensão, um público para seu produto: “um público novo que começa a se desligar dos vícios do cinema comercial nacional 
e estrangeiro para preferir o filme brasileiro de caráter cultural” (ROCHA, 2004, p. 85). Durou pouco, porém, a revolução cultural da DIFILM.

Não obstante, Glauber continua sua "guerra anti-imperialista” no campo cultural, fora do Brasil, de onde pretendeu lutar pela liberdade de expressão e contra a ditadura. Publica, então, A Revolução é uma Eztetyka, manifesto crítico dos nacionalismos (e da ideologia nacionalista usada pela Ditadura Militar), em que propõe a "negação da cultura colonial e do elemento inconsciente da cultura nacional, erradamente considerados valores pela tradição nacionalista” (ROCHA, 2004, p. 99).

Seria, portanto, a tradição nacionalista, principal arma da ditadura que se instalou no Brasil em 1964, condizente com o colonizador, que deve ser combatida por meio de uma arte revolucionária crítica não somente dos valores da "cultura monárquica e burguesa do mundo desenvolvido", mas da ideologia nacional-desenvolvimentista dominante (em especial entre os movimentos artísticos, políticos e vanguardistas, desde a era Vargas). Esses valores deveriam ser criticados em seu próprio contexto, segundo Glauber, para depois serem transformados em instrumentos úteis à compreensão do subdesenvolvimento.

O problema principal colocado no manifesto A Revolução é uma Estética, de 1967, diz respeito à desalienação do próprio artista intelectual, ou seja: "Como poderá o intelectual do mundo subdesenvolvido superar suas alienações e contradições e atingir uma lucidez revolucionária?” (ROCHA, 2004, p. 99). Glauber discute nos filmes, especialmente no Terra em Transe, e nos manifestos a questão da alienação (não somente do povo) como consequência do avanço do sistema capitalista sobre os países colonizados, com o objetivo de descolonizar - não apenas o público, acostumado ao modelo hollywoodiano de filme comercial ou de entretenimento, mas também o cineasta, submetido ao esquema de produção industrial norte-americano, que o alienava do seu produto, o filme.

No bojo de tais mudanças, que sufocaram a revolução cultural brasileira, surgirá então uma nova necessidade para o cineasta e crítico Glauber Rocha, exilado entre França, Itália e Portugal: a de propagar uma "ação desmistificadora dos nacionalismos”. Paradoxalmente, o fortalecimento das produções nacionais era uma das condições para que se desse a própria revolução cultural - invocada no manifesto Revolução Cinematográfica, ainda de 1967, que, mais uma vez, propunha um cinema independente e sem fronteiras: 
Desde que o cinema é um método e uma expressão internacional e desde que este método e esta expressão estão dominados pelo cinema americano associado aos grandes produtores nacionais - a luta dos verdadeiros cineastas independentes é internacional. (ROCHA, 2004, p.101).

Antes de publicar nos Cahiers du Cinemá (ROCHA, 1967) o manifesto do Cine Tricontinental, Glauber Rocha publicou, no mesmo ano, um conjunto de artigos-manifestos sobre cinema e estética que iriam compor o novo manifesto Tricontinental, em que propõe um modo de fazer cinema ainda mais adequado e eficaz para os países colonizados do Terceiro Mundo. Daí os diversos sentidos que vai assumindo sua arte revolucionária ao longo de sua trajetória artística e intelectual, conforme as mudanças no contexto no qual está inserida sua prática cinematográfica e política (seu cinema em processo).

Pois, antes mesmo de esboçar seu modelo de cinema épico-didático, no manifesto Tricontinental (que será aplicado no Der Leone Have Sept Cabeças, produção italiana, de 1970), voltou a Marx, ao propor o caminho da Revolução Cinematográfica com o manifesto dirigido às vanguardas cinematográficas de todo o mundo (uni-vos!), invocando-as a se tornarem independentes, através de um modo de fazer que atingisse não somente o espectador, corrompido pelo modelo hollywoodiano, como também o próprio cineasta alienado pelo modo de produção capitalista.

Glauber chama a atenção para o fato (econômico e cultural) de que a luta contra o sistema capitalista industrial de produção cinematográfica carecia de tomar o poder no campo da distribuição - enquanto etapa da produção fílmica crucial para a sobrevivência do cinema revolucionário -, como havia feito o movimento do cinema novo brasileiro, em sua segunda fase (entre 1964 e 1968), a mais próspera. Para isso, seria necessário que "o maior número possível de produção independente, com distribuição controlada pelos cineastas-produtores" (ROCHA, 2004, 103), invadisse as grandes salas em todo o mundo, extrapolando o circuito das cinematecas e festivais, aos quais estavam praticamente restritas as produções fílmicas independentes, com poucas exceções, a exemplo de grandes diretores como Orson Welles, Hitchcock, Bergman, Bertolucci, que, apesar de inseridos no modo de produção hollywoodiana, mantinham certa independência, mantendo a autoria de suas produções. Assim, a luta dos cineastas independentes, do ponto de vista de Glauber, seria contra a exploração dos produtores e, principal- 
mente, dos distribuidores norte-americanos, que dominavam (e dominam) a produção cinematográfica mundial, e dar-se-ia por meio da Internacional Cinematográfica, que conduziria à verdadeira revolução.

\section{O novíssimo cine Tricontinental}

Não obtendo o apoio desejado para a revolução cinematográfica, Glauber partiu solitário para o projeto do cine Tricontinental, cujo primeiro exemplar seria o Der Leone Have Sept Cabeças, filmado na África, com a ajuda dos produtores (seus amigos) Gianni Bartelonni e Claude Antoine, mas sem distribuição adequada, fato que contribuiu para o fracasso de público e de crítica. Mais uma vez, suas expectativas são fracassadas, ainda assim considerou uma vitória pessoal ter realizado o Leão de Sete Cabeças, manifesto prático do cine Tricontinental. De fato, a existência do filme um dia serviria de exemplo de sua luta anti-imperialista e descolonizadora, que assumiria um caráter um tanto solitário e controverso por, ao menos, duas décadas. Voltando-se contra a crítica internacional, em defesa de seu filme (e enquanto crítico da crítica), Glauber contesta a imprensa europeia: "Não reconheço a autoridade da crítica para julgar com uma linguagem burguesa meus filmes, que não falam segundo o sistema Lacan” (ROCHA apud BENTES, 1997, p. 46).

Aquele conjunto de ideias, colocadas nos manifestos anteriores, não deixará de fazer parte do novo manifesto Tricontinental, que marcou, na trajetória intelectual glauberiana, uma derradeira tentativa de dar forma à sua arte revolucionária, constantemente renovada de acordo com as novas circunstâncias. Com a desintegração do movimento Cinema Novo, a despeito do seu sucesso internacional e desdobramentos, o cineasta Glauber Rocha, exilado entre a França e a Itália, mas tocado pela ação e pelo discurso de Che Guevara aos povos latino-americanos, se lança no projeto do Cine Tricontinental, cuja proposta principal era combater os nacionalismos tradicionais, os colonialismos e neocolonialismos culturais e contribuir para a libertação do Terceiro Mundo, por meio de um discurso fílmico entendido como ato revolucionário. Segundo Glauber, “o ato revolucionário é produto de uma ação que se fará reflexão no processo de luta (tricontinental)” (ROCHA, 2004, p. 104).

Mas o que seria o filme tricontinental? Glauber se pergunta, no manifesto, e responde assumindo a contradição e ambiguidade de um possível cineasta tricontinental: "Um produtor aqui é como um general. [...] Nenhum cineasta 
tricontinental é livre. Não digo livre da prisão ou da censura, ou dos compromissos financeiros. Livre, digo, desse se descobrir homem de três continentes", sendo assim, "qualquer câmera aberta sobre as evidências do Terceiro Mundo é um ato revolucionário” (ROCHA, 2004, p. 104).

$\mathrm{Na}$ qualidade de ato revolucionário, Glauber define o cine Tricontinental como, ao mesmo tempo, "o cinema de autor, o cinema político, o cinema contra [...]", ou seja, tudo aquilo que fora o Cinema Novo e mais: “[...] é um cinema de guerrilha" que, inicialmente, se fez "brutal" e "impreciso", mas se faria "épico-didático". Logo, o manifesto do cine Tricontinental será aqui considerado como um desenvolvimento crítico do manifesto do cinema novo (e do próprio cinema novo, como atualização dos manifestos, um cinema em processo), Uma Estética da Fome, assim como poderá ser entendido, mais uma vez, como uma autocrítica, pois, ainda de acordo com Glauber,

Tricontinental - qualquer outro discurso é belo, mas inofensivo, é racional, mas cansado, é cinematográfico, mas inútil, é reflexivo, mas impotente, e mesmo o lirismo, este paira no ar, nasce da palavra, se faz arquitetura, mas é logo passiva ou estéril conspiração. Aqui, para lembrar Regis Debray, o verbo se faz carne. (ROCHA, 2004, p. 104).

Com estas ideias na cabeça, Rocha vai filmar na África, em 1969, o Der Leone Have Sept Cabeças, considerado manifesto prático do Cine Tricontinental, que, como o Terra em Transe, manifesto prático da Estética da Fome, enquanto arte, ultrapassa, todavia, seus limites (os de suas tentativas de normatização da arte revolucionária) rumo à estética do sonho.

\section{A Eztetyka do Sonho}

Logo na introdução à Eztetyka do Sonho, comunicação realizada na Universidade de Yale, em 1971, Glauber considera de suma importância, observadas as circunstâncias, distinguir três tipos de arte revolucionária:

"Arte revolucionária" foi a palavra de ordem no Terceiro Mundo nos anos 60 e continuará a ser nesta década. Acho porém que a mudança de condições políticas e mentais exige um desenvolvimento contínuo dos conceitos de "arte revolucionária. (ROCHA, 2004, p. 249). 
O primeiro estaria representado naquele tipo de arte cinematográfica útil ao ativismo político, cujo exemplo mais evidente seria o filme La hora de los Hornos (Argentina, 1968, do cinemanovista argentino Fernando Solanas). O segundo tipo tem por característica principal abrir novas discussões, como exemplo cita alguns filmes do Cinema Novo e seus próprios filmes. Por último, a arte revolucionária rejeitada pela esquerda e instrumentalizada pela direita, a exemplo da obra de Jorge Luiz Borges, também argentino. No Brasil, porém,

O pior inimigo da arte revolucionária é a sua mediocridade. Diante da evolução sutil dos conceitos reformistas da ideologia imperialista, o artista deve oferecer respostas revolucionárias capazes de não aceitar, em nenhuma hipótese, as evasivas propostas. (ROCHA, 2004, p. 248).

Em permanente estado de revolta contra tudo que era tradição, tanto no campo da moral (da ética) como no das convenções sociais e dos valores estéticos, Glauber se volta contra a própria cultura cinematográfica europeia, da qual havia compartilhado, e contra o que chama de razão opressora, de origem europeia (ocidental). Não abandona por completo a tentativa de conscientizar (na origem das utopias vanguardistas dos anos 1960, nas quais está imersa sua prática cinematográfica e sua teoria estética), mas, no Der Leone Have Sept Cabeças, radicaliza sua busca do inconsciente coletivo, em direção à Eztetyka do Sonho, em que, invocando o surrealismo de Borges, lança a noção de irracionalidade na arte, seu grito de guerra de independência (ou de autonomia estética): "As vanguardas do pensamento não podem mais se dar ao sucesso inútil de responder à razão opressiva com a razão revolucionária. A revolução é a anti-razão" (ROCHA, 2004, p. 250).

Logo, no manifesto Eztetyka do Sonho, é o conteúdo irracional da cultura do Terceiro Mundo que vai ser valorizado - como uma forma de violentar a razão opressora do colonizador. Pois, como disse Edgar Morin, na tentativa de demonstrar a insuficiência da definição do gênero humano como homo sapiens (o que converge com a crítica glauberiana da razão, além de ajudar a explicar a construção dos personagens nos filmes de Glauber, a qual não pretende ser realista, mas mitopoética, sem jamais separar mito e história nem poética e política): 
Ser homo implica ser igualmente demens: em manifestar uma afetividade extrema, convulsiva, com paixões, cólera, gritos, mudanças brutais de humor; em crer na virtude de sacrifícios sanguinolentos, e dar corpo, existência e poder a mitos e deuses (...) A loucura humana é fonte de ódio, crueldade, barbárie, cegueira. (...) sem as desordens da afetividade e as irrupções do imaginário, e sem a loucura do impossível, não haveria élan, criação, invenção, amor, poesia. (...) O ser humano é um animal insuficiente, não apenas na razão, mas é dotado de desrazão. (MORIN, 2002, p. 7).

A estética do sonho já estava presente também no Terra em Transe, anterior e considerado pelo próprio Glauber como aplicação da estética da fome, manifesto em favor do movimento cinema novo, mas já transcendendo seus limites, como já foi dito, podendo ser considerada a estética do sonho um desenvolvimento da estética da fome, no processo de radicalização do seu projeto estético, dada a natureza política de sua arte revolucionária.

Os dois filmes considerados explicitamente políticos, por Glauber e outros estudiosos, são Terra em Transe, 1967 (analisado no Capítulo II deste), em que coloca a questão do intelectual e faz a crítica do "populismo" (WEFFORT, 2003), e O Leão de Sete Cabeças, de 1970, considerado como o primeiro exemplar do Movimento Cine Tricontinental. Do ponto de vista adotado aqui, interessa a crítica do intelectual em suas relações com o poder discutidas por Glauber nestes filmes. Não só porque em ambos os personagens principais estão imbricados em questões propriamente políticas, ou seja, envolvidos nas lutas sociais (ou na luta de classes), como também, pensando paralelamente na trajetória artístico-intelectual de Glauber Rocha, representam os dois principais momentos de ruptura com o contexto cultural, artístico, sociointelectual de sua época, e, principalmente de seus próprios pressupostos estético-teóricos, na medida em que inauguram novo movimento nas ideias e na prática cinematográfica (não separadas) de Glauber Rocha. No entanto, não se trata de ruptura total, há pontos de continuidade, o que permite falar em passagem. Afinal, "a política está sempre em transe" (ROCHA apud BENTES, 1997, p. 328). 


\section{Considerações Finais}

O verdadeiro progresso não consiste no ter progredido, mas no progredir. (BRECHT apud CHIARINI, 1967, p. 34)

A progressiva démarche cinematográfica glauberiana, no sentido de uma crítica sempre mais radical à sociedade "burguesa" e ao sistema capitalista, caminhou na direção de abertura de novas perspectivas no campo cultural. Tal fenômeno foi particularmente notório nos anos 1960, quando floresceu o Cinema Novo, movimento do qual Glauber foi um dos principais organizadores e seu teórico por excelência. Mais especificamente, procuramos analisar uma passagem fundamental na carreira de Glauber: a transição entre os princípios normativos de sua arte revolucionária, esboçados primeiro na Estética da Fome (1965) e sua tentativa de aplicação prática no Terra em Transe (1967), o primeiro momento de transcendência frente ao manifesto do Cinema Novo, para aqueles princípios estabelecidos na Eztetyka do Sonho (1971), passando pelo manifesto do cine Tricontinental (1967), aplicado no Leone Have Sept Cabeças (1970), que enquanto obra de arte já os transcende rumo à estética do sonho.

Terra em Transe, enquanto manifesto prático da estética da fome, mostrou-se como um divisor de águas, tanto na trajetória artístico-intelectual de Glauber Rocha, quanto no contexto dos movimentos culturais, na passagem dos anos 1960 para a década de 1970, ultrapassando os limites da "estrutura de sentimento da brasilidade revolucionário” (RIDENTE et al., 2006) dos anos 1960 e já prenunciando seu esgotamento. Como bem notou Caetano Veloso, "as imagens de grande força que se sucediam confirmavam a impressão de que aspectos inconscientes de nossa realidade estavam à beira de se revelar”. Caetano, no momento em que foi tocado por Terra em Transe de maneira positiva, ao contrário da quase totalidade dos artistas e intelectuais daquela geração, foi um dos poucos a perceber algo que se revelou, podemos dizer, como um dos traços fundamentais da cinematografia glauberiana, a saber, aquele que se volta para desvelar os mitos mais profundos da cultura brasileira em busca do o inconsciente coletivo brasileiro, como instrumento de descolonização ${ }^{3}$.

3 Todavia, "descolonizar" não implica necessariamente o esforço de apagamento da herança europeia, mas aponta para a possibilidade de acrescentar ou suplementar, no sentido derridiano do termo - em que suplemento (conceito formulado por DERRIDA, 1971) não é apenas aquilo que se adiciona, mas aquilo que, questionando o que foi recalcado desde a origem, contribui para alterar. 
Rocha via nesse processo uma forma de superar o complexo de inferioridade do artista e do intelectual periférico, terceiro-mundista. Sua crítica radical se voltou, principalmente, contra a persistência na sociedade brasileira da lógica colonialista, sem retroceder jamais.

Comparando os manifestos Uma Estética da Fome (1965) a Eztetyka do Sonho (1971), passando pelo Cine Tricontinental (1967), com os filmes Terra em Transe (1967) e Der Leone Have Sept Cabeças (1970), considerados por ele mesmo como manifestos práticos, pode-se chegar à conclusão de que sua arte cinematográfica revolucionária, paradoxalmente, sempre ultrapassa suas tentativas teóricas de normatização (em que estabelece os princípios norteadores de sua obra), evidenciando um constante desenvolvimento dos seus escritos estéticos, publicados no Brasil, na Europa Ocidental e nos Estados Unidos, para sua prática cinematográfica (política). Assim, embora a sua obra artística e sua teoria estética estejam em íntima relação (e ele tenha buscado aproximá-las cada vez mais), a segunda sempre aponta para algo mais, para novos horizontes, seguindo sempre a máxima de Brecht: para novas formas, novos conteúdos e vice-versa.

\section{Referências bibliográficas}

BENTES, Ivana (Org.). (1997), Glauber Rocha, Cartas ao mundo. São Paulo: Cia das Letras.

CHAUI, Marilena. (1994), Conformismo e Resistência: aspectos da cultura popular no Brasil. 6 ed. São Paulo: Brasiliense.

CHIARINI, Paolo. (1967), Bertold Brecht. 1 ed. Rio de Janeiro: Civilização Brasileira.

DERRIDA, Jacques. (1971), A Escritura e a Diferença. 2 ed. São Paulo: Perspectiva.

FANON, Frantz. (2005), Os Condenados da Terra. 4 ed. Juiz de Fora: Ed. UFJF. FOUCAULT, Michel. (1979), Microfísica do Poder. 8 ed. Rio de Janeiro: Graal. MORIN, Edgar. (2002), Amor, Poesia, Sabedoria. 4 ed. Rio de Janeiro: Bertrand Brasil.

NIETZSCHE, Friedrich. (1988), A Genealogia da Moral. 2 ed. São Paulo: Brasiliense.

REIS, Paulo R. O. (2006), Arte de Vanguarda no Brasil - os anos 1960. 1 ed. Rio de Janeiro: Zahar. 
RIDENTE, Marcelo et. al. (2006), Intelectuais e Estado. 1 ed. Belo Horizonte: Ed. UFMG.

ROCHA, Glauber. (2004 [1965]), Estética da Fome. In: ROCHA, Glauber. Revolução do Cinema Novo. Rio de Janeiro: Cosac Naify. pp. 63-67.

ROCHA, Glauber. (2004 [1971]), Eztetyka do Sonho. In: ROCHA, Glauber. Revolução do Cinema Novo. Rio de Janeiro: Cosac Naify. pp. 248-251.

ROCHA, Glauber. (1985), O Século do Cinema. 1 ed. Rio de Janeiro: Alhambra.

ROCHA, Glauber. (1967), O Cineasta Tricontinental. Cahiers du Cinemá, n. 195, pp. 204-213.

SAID, Edward. (2005), Representações do Intelectual (As Conferências Reith de 1993).1 ed. São Paulo: Companhia das Letras.

WEFFORT, Francisco C. (2003), O populismo na política brasileira. 5 ed. São Paulo: Paz e Terra. 


\title{
A Construção de uma Agenda de Investigação Comum em um Oceano de Discordâncias
}

\author{
Renan Springer de Freitas* \\ Gustavo de Castro Patricio de Alencar* *
}

\section{RESUMO}

Este artigo conta a história de como um corpo de conhecimento que sequer se pretende "científico", a Teologia do Novo Testamento, conseguiu estabelecer uma agenda de investigação comum de uma forma que dificilmente pode ser vista (se é que o pode!) no pensamento sociológico. Usualmente se diz que o conhecimento sociológico tende a se fragmentar em razão de não poder contar com um núcleo duro de generalizações empíricas e de concepções aceitas de forma consensual. Pois na Teologia do Novo Testamento falta tanto uma coisa quanto a outra e, não obstante, essa disciplina não se fragmenta em "escolas de pensamento" ou "paradigmas" que mal tomam conhecimento da existência uns dos outros, como ocorre na teoria sociológica, nas abordagens sociológicas sobre a modernidade, na sociologia do conhecimento e em muitas outras áreas do conhecimento sociológico.

Palavras-chave: "Principados" teóricos. Fragmentação do conhecimento sociológico. Paradigmas sociológicos. Teologia do Novo Testamento. Nova Perspectiva sobre Paulo.

\footnotetext{
* Professor Titular de Sociologia da UFMG.

* * Estudante de Doutorado do Programa de Pós-Graduação em Sociologia da UFMG. Professor de Sociologia no Ensino Médio.
} 


\begin{abstract}
BUILDING A COMMON RESEARCH AGENDA IN AN OCEAN OF DISAGREEMENTS

This article tells the story of how a body of knowledge that does not even claim to be "scientific", namely, the Theology of the New Testament, has managed to establish a common research agenda in a way that can hardly be seen (if it can at all!) in the sociological thought. It is usually assumed that sociological knowledge is fated to be fragmented because it cannot rely either on a hard core of empirical generalizations or on conceptions that are consensually accepted. However, New Testament theology also lacks all this, and yet this discipline does not fragment into "schools of thought" or "paradigms" which barely become aware of one another's existence, as it happens as far as sociological theory, sociological approaches of modernity, the sociology of knowledge and many other areas of sociological knowledge are concerned.

Keywords: Theoretical "principalities". Fragmentation of sociological knowledge. Sociological paradigms. Theology of the New Testament. New Perspective on Paul.
\end{abstract}

\title{
Introdução
}

Nesse artigo pretendemos contar a história de como um corpo de conhecimento que sequer se pretende "científico" conseguiu estabelecer uma agenda de investigação comum de uma forma que dificilmente pode ser vista (se é que o pode!) no pensamento sociológico. Para nos fazer entender, solicitamos ao leitor que considere um dos principais temas a que o pensamento sociológico se dedica: a “modernidade”. Sabemos que nas últimas décadas foram produzidas muitas abordagens sociológicas sobre esse tema. Ocorre, entretanto, que essas abordagens mal tomaram conhecimento da existência umas das outras. Tomemos, por ora, dois exemplos: Jean Comaroff, figura-chave da abordagem dita "neocolonial”, e Shmuel Eisenstadt, figura-chave da abordagem das "múltiplas modernidades". Apesar de ambos estarem interessados, sobretudo, em compreender a natureza desse fenômeno usualmente chamado de "modernidade", nem que seja para colocar em xeque o próprio pressuposto de que existe um fenômeno ao qual podemos, sem maiores ressalvas, chamar de “modernidade”, nenhuma interlocução há entre eles. Eisenstadt e Comaroff simplesmente não tomam conhecimento da existência um do outro.

$\mathrm{Na}$ verdade, para quem está familiarizado com a discussão a respeito da fragmentação do conhecimento sociológico nada há de surpreendente em 
constatar um desconhecimento mútuo dessa natureza. Para um autor como Jeffrey Alexander, por exemplo, o fato de na sociologia qualquer tema (seja a modernidade ou qualquer outro) ser abordado por "escolas" que mal tomam conhecimento da existência umas das outras se explicaria facilmente pelo próprio caráter ideológico dos conceitos sociológicos. Com efeito, não há como negar o caráter ideológico de um conceito como o de "modernidade". Para nos limitarmos ao modo como a sociologia clássica concebia o fenômeno ao qual ele presumivelmente se refere, lembremo-nos de que, enquanto Marx o via como o último estágio da longa e tortuosa marcha do ser humano em direção ao processo revolucionário que em um futuro não muito distante o livraria das mazelas sociais, Durkheim o via como a feliz culminação de um processo social no qual a ruptura revolucionária não teria qualquer papel a cumprir e Weber, em contraste com ambos, como uma encrenca em que inadvertidamente nos metemos e da qual dificilmente conseguiremos sair. Conceitos que se prestam a divergências dessa natureza parecem mesmo ter sido talhados para "segmentar", ou "fragmentar", o conhecimento. Some-se a isso a impossibilidade, peculiar ao conhecimento sociológico, de contar com leis gerais, sistemas dedutivos e "peças específicas de evidência empírica”, para falar com o próprio Alexander (1987), e a conclusão parece inescapável: é da natureza da sociologia se fragmentar em "escolas de pensamento"; em ser uma ciência "multiparadigmática”. Nessas circunstâncias, não há mesmo por que esperar o estabelecimento de alguma agenda comum de discussão e, muito menos, de investigação, nas diferentes sub-áreas dessa disciplina.

Se é mesmo da natureza da sociologia ser uma ciência "multiparadigmática” não importa discutir aqui. Importa argumentar, entretanto, que, caso isso seja verdade, a razão não reside nos argumentos apresentados por Alexander. Um contra-exemplo pode esclarecer isto. Consideremos um tema como a teologia Paulina. Tanto quanto a modernidade, o significado teológico dos escritos do apóstolo Paulo é objeto das mais espinhosas controvérsias e essas não podem ser dirimidas pelo apelo a evidências empíricas. $\mathrm{Na}$ verdade, elas não podem ser dirimidas. No entanto, a discussão sobre esse tema não se fragmenta em múltiplos "paradigmas” ou escolas estanques de pensamento. Embora haja figuras consensualmente reconhecidas como exponenciais nessa área de estudos, nenhuma delas é uma "figura-chave" de alguma "escola de pensamento" em particular. Conforme veremos, os gran- 
des estudiosos da teologia Paulina não podem se dar ao luxo de se fechar em algum "paradigma” e desconhecer o que se passa fora dos seus contornos. Isto sugere que, se um tema como a modernidade, como tantos outros no pensamento sociológico, tem sido abordado por diversas "perspectivas teóricas", ou por sistemas teóricos que mal tomam conhecimento da existência uns dos outros; se a abordagem desse tema, como a de tantos outros, longe de conduzir, quer a um esforço bem sucedido de síntese, como ocorre nas ciências naturais, quer a uma agenda comum de investigação e de discussão, como ocorre (conforme veremos) na teologia, tem conduzido, para falar com Robert Merton, a uma "balcanização” da sociologia (MERTON, 1968), isso nada tem a ver com certas peculiaridades corretamente atribuídas a esta disciplina.

Sim, na sociologia a validação do conhecimento geralmente não se dá, como nas ciências naturais, em um plano "empírico-factual”, mas em um plano "lógico-discursivo" (ALEXANDER, 1987); sim, falta-lhe, na maior parte das vezes, um "núcleo duro", por assim dizer, de pressupostos teóricos e de generalizações empíricas consensualmente aceitos como válidos; sim, nessa disciplina não há como recorrer sistematicamente a testes empíricos e, sim, seus conceitos têm muitas vezes um "caráter ideológico"; mas todos esses "sins" não explicam a fragmentação do conhecimento sociológico em diversos "principados", cada qual regido por seu próprio "sistema teórico" - para relembrar a célebre metáfora de Merton (1968, p. 62). Tanto quanto a sociologia, a teologia não dispõe e jamais poderá dispor de alguma "síntese teórica” nos moldes das existentes nas ciências naturais, não conta e jamais poderá contar com leis gerais nem com testes empíricos sistemáticos e, em conexão com tudo isso, o caráter ideológico de seus conceitos é, de um modo geral, tão ou mais pronunciado que na sociologia, mas, não obstante tudo isso, essa disciplina conseguiu estabelecer pelo menos uma agenda de investigação e de discussão comum, de forma tal que o conhecimento por ela produzido não se fragmenta em "principados" alheios ao que se investiga ou se discute fora dos seus próprios "domínios". Neste artigo procuramos mostrar que agenda é essa e como ela pôde se estabelecer. Antes, entretanto, é bom que se esclareça que a teologia não é uma disciplina que pressupõe necessariamente compromisso com dogmas religiosos. Ela tem seu leque particular de temas de investigação como qualquer disciplina consensualmente reconhecida como científica. São exemplos de temas de investigação nessa 
disciplina: a Cristologia do evangelho de João, a relação entre os chamados Antigo Testamento e Novo Testamento, o gênero apocalíptico no livro do profeta Daniel, a doutrina da criação no Gênesis, as interpretações dos escritos de Paulo etc. Feito o esclarecimento, podemos ir adiante.

Conforme veremos, embora a teologia tenha todas as características listadas acima, há um fator que, estando presente, impõe aos estudiosos dos mais diferentes matizes uma agenda comum de investigação e de discussão. Este fator é a existência de algum problema ou enigma específico, tal como o que será apresentado ao leitor na próxima sessão. Talvez seja conveniente explicitar que não é privilégio da teologia apresentar problemas específicos ou desafiadores capazes de estabelecer uma agenda de investigação comum. $\mathrm{Na}$ biologia, por exemplo, toda uma agenda de discussão comum se estabeleceu entre biólogos de diferentes perspectivas teóricas e sub-disciplinares (embriologia, genética e evolução) nas últimas décadas a partir de um enigma que pode ser descrito nos seguintes termos: como um ovo fertilizado se segmenta? ${ }^{1}$ Da mesma forma, a psicanálise seria inconcebível sem um enigma como o da paciente de Freud que sentia dormência no braço e tinha aversão à água sem que nada do ponto de vista clínico justificasse esses sintomas. Se nada havia de errado do ponto de vista neurológico ou circulatório, por que diabos a jovem sentia forte dormência em um dos braços? É justamente um enigma da natureza dos acima descritos que está ausente, por exemplo, nas mais variadas contribuições sociológicas para a abordagem de um tema como a modernidade; um paradoxo ou desafio específico que imponha, $a$ todos os estudiosos do tema, a busca de uma solução. Conforme veremos na próxima sessão, no terreno teológico há críticas a concepções estabelecidas que conduzem a enigmas ou desafios dessa natureza. Cumpre-nos, então, a tarefa de apresentar ao leitor uma dessas críticas e o desafio ou enigma específico ao qual ela acabou por conduzir. É o que faremos na próxima sessão. Mostraremos como um enigma específico, relacionado ao modo como o apóstolo Paulo se relacionava com sua religião avita, o judaísmo, emergiu no pensamento teológico, mais precisamente, em uma área temática conhecida como “Teologia do Novo Testamento”. Identificado o enigma, cumpre-nos uma segunda tarefa: a de mostrar a agenda de discussão e de investigação

1 Veja-se, a respeito, J. Maynard Smith, Shaping life: genes, embryos and evolution. New Haven: Yale University Press, 1998. 
comum que o mesmo impôs aos estudiosos do tema, independentemente de suas filiações "teóricas”, "ideológicas”, institucionais ou denominacionais. Isto será feito na sessão 2.

\section{$1 \mathrm{O}$ surgimento de uma agenda comum de discussão e investigação: a Nova Perspectiva sobre Paulo (NPP)}

A partir dos anos de 1960, teve início um processo de revisão radical do modo como a tradição exegética protestante interpretava, desde os escritos de Lutero, as cartas do apóstolo Paulo. Esse processo conduziu, quase duas décadas mais tarde, ao surgimento de um enigma específico que se impôs a todos os estudiosos do assunto. O início de tudo pode ser creditado ao trabalho do teólogo sueco Kristen Stendhal, que, em um artigo intitulado The apostle Paul and the Introspective Conscience of the West, publicado em 1963, formulou uma crítica devastadora à interpretação de Lutero da doutrina Paulina. De acordo com Lutero, os escritos de Paulo estavam endereçados à questão de como o ser humano pode assegurar a salvação de sua alma. A resposta, segundo ele, residia na "doutrina da justificação pela fé”, o articulus stantis et cadentis ecclesiae - "o artigo sobre o qual a Igreja permanece ou cai”. Para Lutero e toda uma tradição de exegese bíblica que remonta ao pensamento de Santo Agostinho, o termo "justificação" se refere ao ato de um pecador ser declarado "justo", ou "inocente", a despeito de seus pecados e, nessa condição de "inocente”, ou "imaculado", estar pronto para ser aceito no "reino de Deus".

A doutrina de que o homem é "justificado pela fé” foi desenvolvida a partir da leitura das cartas de Paulo, em especial a Epístola aos Romanos, em que se lê no capítulo 3, versículo 28, que "o homem é justificado pele fé, independente das obras da Lei”; e a Epístola aos Gálatas, em que se lê, no capítulo 2, versículo 16, "sabendo, contudo, que o homem não é justificado por obras da Lei e, sim, mediante a fé em Jesus Cristo, também temos crido em Jesus, para que fôssemos justificados pela fé em Cristo e não por obras da Lei, pois por obras da Lei ninguém será justificado”. Para Lutero, esses versículos revelavam a aversão de Paulo ao legalismo judaico, isto é, à concepção segundo a qual a via de acesso à salvação era a submissão à circuncisão e às normas de conduta prescritas pela Torá (o livro sagrado dos judeus). Assim, ao comentar a carta de Paulo aos Gálatas, Lutero afirma: 
Estes [os rivais de Paulo] ensinaram que, além da fé em Cristo, as obras da Lei divina [isto é, a submissão às normas ditadas pela Torá] seriam necessárias para a salvação. [...] Por essa razão, o apóstolo investe contra eles tão acerbamente, chamando-os de perturbadores das igrejas, porque, além da fé em Cristo, ensinavam que a circuncisão e a observação da Lei seriam necessárias para a salvação. [...] Os pseudo-apóstolos, portanto, com grande empenho e obstinação, insistiram na Lei [Torá], aos quais, sem demora, juntaram-se judeus obstinados que sustentavam que a Lei devia ser guardada. Persuadiram, então, os que estavam pouco firmes na fé, que Paulo não era um verdadeiro mestre, porque negligenciava a Lei. (LUTERO, [1531]2008, p. 72).

A história do enigma de que aqui nos ocupamos tem início quando Stendhal, em seu citado artigo, se insurge contra toda essa linha de raciocínio. Ele argumentou que Lutero, ao interpretar os escritos de Paulo como uma luta contra o legalismo judaico, estava apenas projetando, nesses escritos, sua própria luta pessoal contra o pecado, manifesta em suas divergências pessoais com a Igreja Católica. Esta ensinava que a estrada real para a salvação era a realização das "boas obras”. Vendo-se incapaz de realizá-las, Lutero enxergou nas cartas do Apóstolo uma oportunidade para solucionar o seu próprio problema: da mesma forma que Paulo havia se recusado a aceitar o (suposto) preceito legalista judaico de que o homem deve realizar as "obras da Lei”, ele, Lutero, em estrita analogia ao que Paulo fizera, recusar-se-ia a aceitar o preceito católico de que o homem deve realizar "boas obras". Foi esta recusa que, em última análise, o teria levado a postular que para Paulo a "justificação" seria obtida pela fé, independentemente das "boas obras" (como, por exemplo, a caridade).

Nessa linha de raciocínio, a interpretação de Lutero se limitava a exprimir a "consciência introspectiva do Ocidente": à guisa de interpretar as cartas de Paulo, argumenta Stendhal, Lutero tão somente manifestava a preocupação egoísta, típica do "Ocidente”, com o destino pessoal no "outro mundo". Paulo, na verdade, jamais esteve preocupado com isso, e Lutero, ao ler as cartas de Paulo como se fosse esta a sua preocupação, teria influenciado de forma equivocada não só a Calvino, mas a toda uma tradição exegética que ainda estava em vigor em pleno séc. XX, da qual faziam parte teólogos da estatura de Karl Barth e Rudolf Bultmann.

Quer seja essa crítica pertinente ou não, ela significou uma reviravolta nos estudos Paulinos, a qual viria a ganhar, cerca de duas décadas mais 
tarde, uma designação especial, The New Perspective on Paul (NPP), após a publicação, em 1983, de um artigo acadêmico com esse título. O autor, o teólogo anglicano James Dunn, a quem retornaremos de forma mais detida na próxima sessão, é ainda hoje reconhecido como um dos mais destacados estudiosos do Novo Testamento da segunda metade do séc. XX. A "Nova Perspectiva sobre Paulo", ou, simplesmente, "Nova Perspectiva”, como posteriormente viria a ser chamada, não ficou restrita a um grupo de admiradores de Stendhal e Dunn. Não se limitou a ser um "principado" teológico, em meio a tantos outros, para mais uma vez relembrar a esplêndida metáfora de Merton. Ela foi assimilada por todos os estudiosos do Novo Testamento, mesmo por aqueles que têm sérias reservas à crítica de Stendhal à tradição exegética protestante e, passados quase 35 anos desde que Dunn publicou o referido artigo, não há estudioso do assunto que possa ignorá-la. A Nova Perspectiva, sem aspas, longe de se tornar um "principado", ou uma "república balcânica”, tornou-se uma agenda de discussão e de investigação comum. Mas, por quê? Por que em áreas temáticas da teologia se pode levar a sério a ideia de que há mesmo uma Nova Perspectiva, com N e P maiúsculos e sem aspas, sobre o tema em discussão, de uma forma que não se vê nas diferentes áreas temáticas da sociologia? Por que, em outras palavras, a avalanche de críticas dirigidas ao esforço pioneiro de síntese teórica empreendido por Parsons não conduziu a algo como uma Nova Perspectiva Teórica (NPT), nem a rejeição da chamada "teoria funcionalista da modernização", que dominou o cenário acadêmico nas décadas de 1950 e de 1960, conduziu a uma única Nova Perspectiva sobre a Modernidade (NPM), no mesmo sentido em que a rejeição da tradição exegética luterana sobre os escritos Paulinos conduziu à Nova Perspectiva sobre Paulo (NPP)? Oferecer uma resposta para essa questão é compreender por que o conhecimento teológico não se fragmenta em escolas estanques apesar de estar envolto em um oceano de discordâncias.

A resposta que temos a oferecer é a seguinte: não há uma NPT nem uma NPM porque, diferentemente do que ocorre nos esforços de síntese teórica que não conduziram a uma "NPT" e do que ocorre nos estudos sobre a modernidade que não conduziram a uma "NPM", nos estudos sobre o Novo Testamento, uma mesma questão veio a se impor a todos os estudiosos da área a partir da formulação de uma crítica a uma tese que havia sido formulada há mais de quatro séculos e cuja validade jamais havia sido posta seriamente em xeque desde então. A crítica foi a de Stendhal, a tese, a de Lutero, e a 
questão que veio a se impor pode ser resumida nos seguintes termos: se o objetivo da pregação de Paulo não era mostrar aos prosélitos o que fazer para obter a salvação no "outro mundo", qual seria, então, o significado teológico do seu trabalho missionário e qual o significado de suas cartas para o cristianismo?

Uma pergunta de natureza genérica como essa pode se desdobrar em várias perguntas específicas, e uma pergunta específica particularmente desafiadora veio a ser formulada em 1977 pelo teólogo protestante E. P. Sanders, através de seu livro Paul and Palestine Judaism. Com efeito, esse livro trouxe para a exegese dos escritos de Paulo um desafio que se tornou incontornável para todos os estudiosos da área. Assim é que, passados 21 anos de sua publicação, o citado teólogo James Dunn se viu impelido a escrever um outro livro, agora com mais de oitocentas páginas, para se haver com esse desafio (DUNN, 1998). Saibamos, então, do que se trata. Saibamos o que o livro de Sanders acrescentou a ponto de levar um outro teólogo da mais elevada estatura, Donald A. Hagner, a afirmar, em 1993, que esse livro provocou uma "revolução coperniciana” nos estudos de Paulo (HAGNER, 2001). Qual foi o desafio, trazido por Sanders, responsável por esse "terremoto" na teologia do Novo Testamento, como viria a dizer, em 2004, o teólogo sueco Daniel Marguerat (2011, p. 11)? Que enigma ou desafio, afinal de contas, reuniu em torno de si teólogos de diferentes matizes e escolas de pensamento em busca de uma solução, constituindo, dessa forma, essa agenda comum de discussão e de investigação que é até hoje conhecida pelo nome de a Nova Perspectiva sobre Paulo?

Toda a linha de argumentação e interpretação da tradição exegética protestante se sustenta, conforme vimos, sobre a premissa de que o judaísmo da época de Paulo era uma religião legalista. Para interpretar os escritos de Paulo da forma como Lutero e todo o pensamento protestante até meados do séc. XX o fizeram, seria necessário pressupor que existe um interlocutor legalista contra o qual Paulo argumenta que somos "justificados pela fé” e não pelas “obras da Lei”. Se, porventura, fosse abalado o pressuposto de que o judaísmo na época de Paulo não vinculava a aceitação do ser humano por Deus ao cumprimento da Lei, aqui entendida como o modo de ser e viver prescrito pela Torá, seria necessário reinterpretar os escritos de Paulo. É de certa forma isso que a Nova Perspectiva vai demandar: uma revisão das características da religião judaica com a qual Paulo havia dialogado e a exploração de todas as implicações dessa revisão. 
Já, no início do século XX, diversos estudiosos colocaram em questão, através de novos achados arqueológicos e um maior diálogo com os estudos promovidos por pensadores judeus, a imagem que o protestantismo mais tradicional tinha sobre o judaísmo, de tal forma que ficou difícil sustentar que para um judeu do tempo de Paulo a salvação decorreria do cumprimento da Lei judaica. E. P. Sanders foi um dos principais autores a chamar a atenção para isso (DUNN, 2011, p. 33). Ele não foi o único nem o primeiro a fazê-lo, mas, de acordo com James Dunn, os protestos dos que vieram antes de Sanders não foram ouvidos.

A novidade introduzida por Sanders pode ser melhor entendida se tivermos em conta a seguinte crítica a Paulo formulada pelo teólogo protestante Lloyd Gaston:

A ideia de que Paulo teria abolido a Lei é o que mais tem aborrecido não só os intérpretes judeus, mas a quem quer que tenha algum conhecimento sobre o conceito de Torá [Lei] nos escritos judaicos. Não é tanto a invectiva de Paulo o que incomoda, mas sua ignorância. Para quem compreende o judaísmo rabínico, os ataques de Paulo [ao suposto legalismo judaico] são não apenas injustos, mas totalmente fora de propósito. Os rabinos nunca falam da Torá como um meio de salvação, e quando falam em salvação, se é que o fazem, o modo da Torá, "que é a vossa vida" (Dt: 32:47), é esta salvação. O zelo ético dos rabinos torna-se ainda mais fervoroso em razão de acreditarem que os mandamentos expressam a vontade de Deus para o bem de Israel, mas eles jamais podem, por isto, ser tachados de legalistas. (GASTON, 1987, p. 18).

A novidade introduzida por Sanders está em mostrar que Paulo não desconhecia os ensinamentos rabínicos acima mencionados. Paulo não era o “ignorante” que Gaston supunha ser. Gaston, como Sanders, contrariou toda uma tradição exegética que atribuía ao judaísmo dos tempos de Paulo um caráter legalista, mas Sanders acrescentou que Paulo, bom judeu que era, sabia muito bem que a religião judaica não tinha esse caráter. Nessa perspectiva, ao contrário do que supunha Gaston, o alvo do ataque de Paulo em suas pregações não era o legalismo judaico. Qual teria sido, então? Se Paulo sabia que o judaísmo não era uma religião legalista, se ele sabia que "os rabinos nunca falavam da Torá (Lei) como um meio de salvação”, se ele sabia que todos sabiam que a salvação nada tem a ver com a submissão à circuncisão, às restrições dietárias e às datas festivas do calendário judaico, se ele sabia 
que "salvação" não era um tema relevante para a doutrina rabínica, se ele sabia de tudo isto, que diabos, então, ele queria dizer ao afirmar, em vários momentos, que “a justificação é pela fé e não pelas obras da Lei”? Se Paulo, com essas palavras, não estava enfrentando o legalismo judaico, posto que nem mesmo os judeus eram legalistas, o que ele estava enfrentando afinal de contas? Por que Paulo insistia em pregar que a salvação "não é pelas obras da Lei” se não havia quem sustentasse que fosse?

Eis, aí, o enigma específico a que a crítica de Stendhal ao pensamento de Lutero acabou por conduzir. Esse enigma, conforme veremos, impôs aos estudiosos do assunto, a começar pelo próprio Sanders, a busca de uma solução. A solução oferecida pelo próprio Sanders é a de que os judeus não eram legalistas, mas "nomistas", isto é, seguiam, sim, as prescrições da Torá, mas não por entenderem que agindo assim assegurariam a salvação. Esta já estava assegurada pela aliança que haviam feito com Deus, por meio do patriarca Abrahão, conforme consta no livro do Gênesis ${ }^{2}$. Se seguiam a Torá (Lei) é porque acreditavam ser essa a condição para a permanência nessa aliança. Quer seja boa ou ruim, esta solução abriu um campo formidável de inquirições e investigações adicionais, conforme veremos na próxima sessão. Nesse sentido, o lugar de Sanders na Nova Perspectiva não se restringe à solução que ele ofereceu para o referido enigma, conforme deixa claro o excerto abaixo, mais uma vez de James Dunn:

Ele [Sanders] chamou a atenção para algo que não era tão novo em si mesmo - o caráter do judaísmo palestinense como sistema religioso postulado pela iniciativa da graça divina, mas fez isso com tal efeito que ninguém que alimente aspirações sérias de entender os primórdios cristãos em geral ou a teologia Paulina em particular pode agora continuar ignorando o contraste agudo que ele estabeleceu entre sua exposição do judaísmo palestinense e as reconstruções tradicionais do judaísmo na teologia cristã. Nada se tornou mais necessário que a reavaliação completa do relacionamento de Paulo com sua religião avita, para não falar de todas as consequências importantes que seguiram para a nossa compreensão contemporânea de sua teologia. (DUNN, [1998] 2003, p. 30)

2 "Esta é a minha aliança, que guardareis entre mim e vós e a tua descendência: todo macho entre vós será circuncidado. Circuncidareis a carne do vosso prepúcio; será por sinal de aliança entre mim e vós" (Gn 17, 10-11). 
Essa passagem mostra com clareza qual foi a demanda imposta, aos estudiosos do Novo Testamento, pelo enigma a que a contribuição de Sanders conduziu: a "reavaliação completa" da relação entre Paulo e o judaísmo, sua "religião avita”. Responder a essa demanda é oferecer uma resposta para a questão mais abrangente que, conforme vimos, confere unidade à Nova Perspectiva - recapitulando: posto que o objetivo da doutrina de Paulo não era mostrar aos prosélitos o que fazer para assegurar a salvação, qual seria, então, o significado teológico de seu trabalho missionário e qual o significado de suas cartas para o cristianismo? É chegado o momento de mostrarmos as diferentes contribuições específicas endereçadas à solução dessa questão.

\section{$2 \mathrm{O}$ enfrentamento de um problema comum}

Se um tema como a "modernidade" remete, em nossos dias, a nomes como Wallerstein, Eisenstadt e Giddens, um tema como a "exegese do Novo Testamento" remete a nomes como James Dunn, Nicholas T. Wright e Stephen Westerholm. Se os três primeiros nomes não remetem a algo que possa ser chamado de a "Nova Perspectiva sobre a Modernidade", mas a três "sistemas teóricos" que mal tomam conhecimento da existência uns dos outros, a "teoria do sistema mundial", a teoria das "múltiplas modernidades" e a "teoria da modernização reflexiva”, os três últimos convergem em uma mesma direção, a Nova Perspectiva sobre Paulo, na medida em que todos os três estão envolvidos em solucionar um mesmo enigma específico que começou a se delinear, conforme vimos, a partir da crítica de Stendhal à interpretação de Lutero dos escritos de Paulo. Há de se registrar que nem em um caso nem no outro a lista se pretende exaustiva, nem, sequer, a que necessariamente faz mais "justiça” ao que de melhor já se produziu nas áreas de estudo em consideração. Não obstante, em ambos os casos não há quem possa contestar a excepcional estatura dos nomes listados.

James Dunn já foi apresentado ao leitor. Entretanto, cabe acrescentar que ele ostenta em seu Curriculum a distinção de ter sido Presidente da Studiorum Novi Testamenti Societas, a mais reconhecida agremiação acadêmica europeia dedicada aos estudos do Novo Testamento. Cabe também informar que, a despeito dos elogios hiperbólicos dirigidos por ele a Sanders, não há qualquer proximidade institucional ou denominacional entre ambos. Nem sequer se pode afirmar que há alguma deferência especial à senioridade de 
Sanders, que é apenas dois anos mais velho que Dunn. Nascido em 1937, Sanders é norte-americano, protestante liberal e seu principal vínculo institucional é com a Universidade de Duke, Carolina do Norte, enquanto Dunn, nascido em 1939, é britânico, anglicano (como já dito) e professor de Novo Testamento na Faculdade de Durham, Reino Unido.

N. T. Wright, o segundo nome da nossa lista, nasceu em 1948. Ele não ostenta ainda em seu Curriculum uma distinção como a citada, mas, ainda assim, e mesmo a despeito de ser quase dez anos mais jovem, sua estatura acadêmica rivaliza com a de Dunn. Referência obrigatória nos estudos sobre a carta de Paulo aos Romanos, em que aparece de forma particularmente destacada a célebre passagem de que a "justificação" se dá "pela fé”, sua contribuição mais importante reside em seu livro What Saint Paul really said: was Paul of Tarsus the real founder of Christianity?, publicado em 1997. Muito recentemente, em 2013, publicou um livro de mais de 1700 páginas intitulado Paul and the Faithfulness of God, no qual apresenta uma pesquisa detalhada sobre a vida de Paulo, o contexto histórico e religioso no qual ele estava inserido e uma análise de suas cartas contidas no Novo Testamento.

Nosso terceiro herói, o teólogo canadense Stephen Westerholm, não rivaliza em estatura acadêmica com os dois anteriores, mas sua formação filológica faz de sua obra uma das mais relevantes contribuições para os estudos do Novo Testamento das últimas décadas. Westerholm foi trazido à consideração por ser uma das mais importantes vozes discordantes no debate sobre a relação entre Paulo e o judaísmo. Trata-se, entretanto, conforme veremos, de uma discordância que não lhe permite mover-se à margem do objeto da discordância, no caso, a tese de que o judaísmo na época de Paulo era, como havia proposto Sanders, uma religião "nomista”, mas não legalista. Para contestar essa ideia, Westerholm se viu forçado a realizar uma profunda investigação de natureza filológica. Giddens não precisou se envolver em investigação de qualquer natureza, seja histórica, sociológica, arqueológica ou filológica para contestar as ideias de "figuras chaves" de outras escolas como Wallerstein e Eisenstadt. O mesmo não pode ser dito de Westerholm, conforme veremos. Como sua crítica a Stendhal, Sanders, Dunn, Wright e muitos outros estudiosos foi formulada em resposta a um desafio colocado para todos, essa crítica é também, em si, uma resposta a esse desafio, requerendo, então, do crítico, o próprio Westerholm, algum tipo de investigação original. 
Apresentadas algumas das vozes mais importantes do debate imposto pelo enigma descrito na sessão anterior, é chegado o momento de mostrar o padrão de interlocução que esse enigma impôs a essas diferentes vozes. Iniciemos pelo sênior, James Dunn.

Para Dunn, a chave para a solução do enigma está em entender o que movia Paulo em uma polêmica específica, a ocorrida entre ele e aqueles que ele próprio chamava, tanto nos Atos dos Apóstolos quanto em suas cartas aos Gálatas e a Tito, de "os da circuncisão”. ${ }^{3}$ Essa expressão se referia aos judeus contemporâneos de Paulo que haviam se convertido ao cristianismo sem, entretanto, abrir mão de práticas judaicas, como a circuncisão, as restrições dietárias e, às vezes, a própria celebração do Shabat. Em sua pregação, Paulo polemizava com eles argumentando que essas práticas deveriam ser abolidas. Admitido isso, a questão que se coloca é por que Paulo advogou a abolição dessas práticas. Antes do advento da Nova Perspectiva, a resposta parecia fácil: ele o fez simplesmente para ensinar aos judeus tornados cristãos que as práticas judaicas não eram uma via de acesso à salvação. Nada haveria, então, de enigmático no fato de Paulo ter se dado ao trabalho de polemizar com "os da circuncisão". Assim presumia a tradição exegética protestante. Segundo essa tradição, se no Gênesis estava escrito que a circuncisão era o "sinal da aliança” (reveja-se a nota 4) entre Deus e o patriarca Abrahão, então, aos olhos de um judeu, ainda que convertido ao cristianismo, não havia outro modo de ser aceito por Deus a não ser circuncidando-se. O papel de Paulo, nessa perspectiva, teria sido o de explicar a esses recém-convertidos que a vinda de Jesus, o Messias anunciado ao povo de Israel, tornara dispensável não só a circuncisão mas, também, a observância de qualquer rito judaico, porque agora o pertencimento à aliança (e, como corolário, a salvação) não dependia mais disso. Um resumo da controvérsia entre Paulo e "os que eram da circuncisão" tal como era (equivocadamente) entendida pela tradição exegética protestante é apresentado por Dunn nos seguintes termos:

Paulo contestou a necessidade da circuncisão porque ela era um exemplo primário de obra meritória, de salvação auto-alcançada, algo impossível para uma criatura e para um pecador em seu afã de permanecer diante do Deus cria-

3 Atos dos Apóstolos cap. 11, versículo 2 (At 11, 2); Carta de Paulo aos Gálatas cap. 2, versículo 12 (Gl 2, 12) e Carta de Paulo a Tito cap. 1, versículo 10 (Tt 1, 10). 
dor e salvador. Paulo foi questionado por um judaísmo legalista, que ele enfrentou e contestou como o defensor da justificação pela fé (DUNN, 2011, p. 232).

Do ponto de vista da Nova Perspectiva, Paulo havia contestado a necessidade da circuncisão por motivos completamente diferentes. Se o judaísmo do primeiro século não era uma religião legalista, e se Paulo sabia disso, então ele não teria qualquer razão para exortar os judeus tornados cristãos a não se submeterem às prescrições da Torá sob o argumento de que essas prescrições não eram a via de acesso à salvação. $\mathrm{O}$ argumento teria que ser de outra ordem. Nesse sentido, tudo o que até então se pensava a respeito da controvérsia entre o apóstolo e "os da circuncisão” precisava ser revisto. Se o que Paulo combatia não era o legalismo judaico, expresso na imposição de práticas como a circuncisão, então o que pretendiam "os da circuncisão” se não era assegurar a salvação? Por que se opunham a Paulo? Eis o enigma que Dunn se prontificou a solucionar.

Em linhas gerais, sua solução consiste em postular que, longe de ser a busca da salvação, o que realmente motivava "os da circuncisão" a obedecer a lei judaica era uma razão bem mais prosaica: delimitar fronteiras de identidade. A Torá (Lei), todos sabiam, não era um meio de acesso à salvação, mas poderia servir como um meio de distinguir aqueles que pertencem à descendência de Abrahão e, por esse meio, à aliança com Deus, daqueles que não pertencem. Os judeus do tempo de Paulo, argumenta Dunn, possuíam um senso de privilégio por se entenderem como uma nação separada das demais, de forma que as fronteiras entre o seu grupo e os outros eram incentivadas de forma enfática. O que Paulo estaria atacando, então, seria essa autoimagem judaica que ainda permanecia naqueles que haviam sido convencidos de que Jesus era o Messias anunciado pelas escrituras judaicas. Em outras palavras, o alvo do ataque era

[...] a confiança típica do judeu de estar em uma posição de privilégio e de superioridade ética, em virtude de ter a Lei. [...] O que Paulo procura minar, o ápice da acusação, é o típico 'gloriar-se na Lei' judaico (Rm 2. 23) - isto é, o orgulho existente no nomismo da aliança de que, vivendo dentro da Lei, preservando a identidade da aliança (o ser distinto judaico), não obstante os pecados individuais, preserva-se a posição privilegiada judaica diante de Deus” (DUNN, 2011, p. 251).

Nessa perspectiva, se Paulo se opunha à prática da circuncisão entre os “da circuncisão”, era em razão de ver nessa prática um “marcador de identi- 
dade" que estabelecia fronteiras sociais, algo que, segundo ele, não deveria mais existir após a chegada do Messias, uma vez que, com esse acontecimento, a promessa que Deus fizera a Abrahão - conforme Gênesis, 12:2-3: “e far-te-ei uma grande nação, e abençoar-te-ei e engrandecerei o teu nome; e tu serás uma bênção. E abençoarei os que te abençoarem, e amaldiçoarei os que te amaldiçoarem; e em ti serão benditas todas as famílias da terra” - não mais ficaria restrita ao povo judeu; ela se expandiria para todas as nações. $\mathrm{O}$ que Paulo combatia nos judeus não era, então, seu legalismo, mas seu exclusivismo, sua “típica” propensão a estabelecer fronteiras sociais. É o bastante para Dunn. Passemos a Wright.

Se, para Dunn, a chave para entender o significado teológico da doutrina Paulina da "justificação pela fé" estava em entender o que motivava Paulo em sua polêmica com "os da circuncisão", ${ }_{4}^{4}$ para Wright, a chave não estaria em alguma polêmica em particular, mas na compreensão do significado de um termo específico que já aparece no livro do Gênesis: “aliança”. No rastro das contribuições de Sanders e Dunn, Wright sustenta que o termo "justificado" não se refere a quem foi declarado "inocente" apesar de seus pecados, mas a quem se mostrou digno de pertencer à "nova aliança". No passado, Deus selou um pacto com o povo judeu confiando-lhe a missão de difundir seus mandamentos a todos os povos da Terra. Os judeus falharam em cumprir essa missão e Deus, diante desse fracasso, fez uma nova tentativa, enviando o Messias anunciado no próprio livro sagrado dos judeus para que este, através de seu sacrifício, iniciasse um novo pacto, ou uma "nova aliança”, não com um povo específico, mas com todos aqueles que viessem a crer em seu sacrifício redentor. Dessa forma, aquilo que não havia se realizado por meio da primeira aliança seria agora realizado por meio da "nova aliança". Nessa perspectiva, quando Paulo dizia que a "justificação" se dá pela fé, o caminho para o qual ele estava apontando não era, como supunha a tradição exegética protestante, o da salvação, mas o do pertencimento a essa "nova aliança”. Wright segue Sanders e Dunn até aí e se propõe a ir adiante esclarecendo o que significa exatamente "pertencer à nova aliança". O que se entendia por "nova aliança" no mundo mediterrâneo de Paulo? Suas investigações se destinam a responder essa pergunta. Em linhas gerais, sua contribuição original está em postular que no mundo mediterrâneo de

4 Veja-se J. Dunn, “What was the issue between Paul and "those of the Circumcision”, 1998. 
Paulo o termo "aliança" não dizia respeito apenas ao pacto ocorrido no passado, como descrito no parágrafo anterior, mas, também, a um novo pacto a ocorrer no futuro, na verdade, em um futuro que se supunha próximo, no qual o Messias retornaria para restaurar a paz e julgar todas as nações. Todas as pessoas teriam, então, que prestar contas a Deus. Ser declarado "justo", nessa perspectiva, seria de fato ser declarado digno de ser aceito na "nova aliança”; entretanto, não somente na que já havia ocorrido, mas, sobretudo, na que estava para ocorrer. Tanto em um caso como no outro, a fé no sacrifício redentor de Cristo era o caminho.

O caráter ideológico, apologético, de toda essa linha de raciocínio salta à vista. Tanto a visão de Dunn quanto a de Wright reeditam a imagem laudatória que o Cristianismo construiu a respeito de si próprio desde os tempos patrísticos. De acordo com essa imagem, o Cristianismo teria sido a religião que tornou diferenças étnicas e sociais irrelevantes ao substituir, por meio do trabalho missionário do apóstolo Paulo, os "laços de sangue”, valorizados pelo judaísmo, por uma fraternidade universal baseada na "fé em Cristo". Essa visão laudatória vem sendo fortemente criticada nas últimas décadas no interior do próprio pensamento teológico cristão, tendo recebido a denominação derrogatória de "teologia da superação" (displacement theology), assim chamada por postular que a Bíblia Hebraica (chamada pelos cristãos de "Antigo Testamento") não tem qualquer significado teológico a não ser o de anunciar a chegada redentora de Cristo. Nesse particular, nada há de novo na Nova Perspectiva, não, pelo menos, nas versões “James Dunn” e “N. T. Wright" da Nova Perspectiva.

No entanto, e esse é o ponto que aqui nos interessa, o caráter ideológico, patentemente apologético, talvez até mesmo antissemita, dessas contribuições não tem um efeito segmentador no pensamento teológico porque o que conta, nesse caso, é a identificação de problemas específicos: no primeiro caso, entender por que Paulo se deu ao trabalho de polemizar com "os da circuncisão" se esses não buscavam com isso a salvação e Paulo sabia disto; no segundo, esclarecer o que se entendia por "nova aliança” no mundo mediterrâneo de Paulo, cuja solução é de fundamental importância para o esclarecimento da questão geral que move a NPP: o significado teológico das cartas de Paulo. Se as soluções propostas por Dunn e Wright têm um caráter "superacionista”, isso não impede, entretanto, que se formule uma solução alternativa, que não tenha esse caráter. E, de fato, essa solução já está esbo- 
çada, por exemplo, no trabalho da teóloga católica Rosemary Ruether (1974), a quem se credita a autoria da expressão “teologia da superação”.

$\mathrm{O}$ argumento de Ruether se articula em torno de uma informação que, embora de crucial relevância, não foi trazida à consideração por Dunn nem por Wright, a saber: é um preceito farisaico (judaico), e não uma invenção de Paulo, a ideia de que um não-judeu está isento de se submeter aos modos de pensamento dos judeus. Eram os próprios rabinos, e não os cristãos, que ensinavam que somente os judeus teriam que observar todo o conjunto de prescrições e rituais da Torá. Para um não-judeu, como era o caso de "os da circuncisão", bastava seguir as sete leis de Noé, prescritas no Talmude (Sanhedrin, 56a - 60b). As leis de Noé são um conjunto muito simples de proibições: à idolatria, a evocar o nome de Deus em vão, ao roubo, ao assassinato, à má conduta sexual e à crueldade com os animais, acrescidas de um mandamento segundo o qual se deveriam estabelecer tribunais de justiça que assegurassem localmente a observação dessas proibições. Muitos dos fariseus contemporâneos de Paulo já criam que qualquer gentio que pudesse guardar as sete leis de Noé seria um "justo” e, portanto, teria seu lugar "no mundo vindouro" (KEENER, 2005, p. 538), pois a observância dessas leis era tudo o que ele necessitava para assegurar a salvação. Nesse sentido, diferentemente do que Dunn e Wright parecem presumir, Paulo não teria rompido com a tradição judaica, muito menos pregado a abolição de barreiras étnicas e sociais, ao ensinar que um não-judeu está livre das injunções rituais do Antigo Testamento. Na verdade, tanto Dunn quanto Wright parecem desconhecer que a tradição judaica prevê não um, mas dois caminhos para a salvação, um para os judeus, outro para os não-judeus, e o que Paulo fazia era mostrar o caminho a ser seguido pelos não-judeus. Nessa linha de raciocínio, desenvolvida por Ruether, seria exatamente a perspectiva universalista de Israel que permite aos não-judeus se relacionarem com Deus à sua própria maneira e que lhe autoriza ter sua maneira particular de relacionar-se com Ele através da aliança do Sinai.

Eis, assim, em breves palavras, o que seria uma solução não-superacionista, ou anti-superacionista, para a questão levantada por Dunn e retomada por Wright. É verdade que, na contramão do movimento iniciado pela crítica de Stendhal à tradição exegética protestante, essa solução requer que a doutrina da justificação pela fé tenha, sim, uma conexão com a preocupação com a salvação individual. A perspectiva de Dunn, conforme vimos, 
exclui essa possibilidade, como também a visão de Wright, mas não a visão de Westerholm, o terceiro nome de nossa lista, conforme veremos. Nesse sentido, nem mesmo o ato de reeditar a visão laudatória que o Cristianismo construiu a respeito de si próprio, segundo a qual o trabalho missionário de Paulo teria efetuado a transição de uma religião particularista, étnica, o judaísmo, a uma religião universal, que desconhece fronteiras étnicas, sociais ou de qualquer natureza, o próprio cristianismo, nem mesmo o fato de alguns teólogos cristãos subscreverem de forma irrefletida um autoelogio dessa natureza enquanto outros o rechaçam com veemência - como é o caso de teólogos como Lloyd Gaston e Rosemary Ruether, já citados -, nem mesmo um desacordo dessa natureza fragmenta o conhecimento teológico em "escolas de pensamento" que mal tomam conhecimento da existência umas das outras, porque a todos, católicos, protestantes, judeus ou quem quer que se interesse pelo assunto, incluindo ateus, a todos, "superacionistas" e "anti-superacionistas", é imposta uma agenda de investigação comum: investigar o que estava em jogo nas pregações Paulinas, inclusive se o que estava em jogo era mesmo, como imaginava a tradição exegética protestante, a preocupação com a salvação individual. Afinal, pelo menos em um ponto a exegese rabínica convergia com essa tradição: ambas pressupunham que a noção bíblica de "justificação” se refere mesmo à questão de como assegurar a salvação no "mundo vindouro", não obstante os protestos desencadeados pela crítica de Stendhal a Lutero. Mas, ainda que não houvesse essa convergência, não seria possível que essa tradição tivesse seu grão de razão? Para além de uma possível conexão entre "justificação” e salvação da alma, não poderia haver, também, alguma forma "legalista" de judaísmo nos tempos de Paulo? Não poderia haver, da parte do próprio Paulo, alguma genuína preocupação com a salvação individual?

Essas perguntas não desapareceram do horizonte de muitos teólogos do Novo Testamento, um dos quais merece especial destaque por sua incomum erudição: Stephen Westerholm. Em 2003 ele publicou o livro Perspective old and new on Paul: the "Lutherean" Paul and his critics, com o objetivo de reabilitar a interpretação de Lutero dos ataques iniciados com o trabalho de Stendhal. Seu livro é marcado por análises de textos e de termos em hebraico e em grego que apontam para o fato de que, na época de Paulo, existiam, sim, escolas judaicas que disseminavam a ideia de que a salvação requeria submissão às obras da Lei. As exegeses das cartas de Paulo contidas no livro 
são caracterizadas por uma riqueza de detalhes e rigor técnico que torna a reprodução de cada ponto de sua argumentação inviável para quem, como o autor desse trabalho, não é versado em filologia grega e hebraica. Para demonstrar que no judaísmo do primeiro século havia mesmo um legalismo e que a interpretação de Lutero era válida, Westerholm verticaliza sua investigação a ponto de comparar o modo como certos termos e expressões aparecem nos textos de Paulo com o modo como esses mesmos termos e expressões aparecem em outros textos da mesma época.

Nesse sentido, se as teses centrais da Nova Perspectiva sobre Paulo não estão acima de crítica, o fato de elas serem soluções tentativas para um mesmo enigma faz com que a própria crítica seja também, ela própria, uma solução tentativa para esse enigma, uma solução que não pode ser proposta à margem de alguma investigação especializada, original, seja de natureza filológica, histórica, sociológica ou arqueológica. Em muitas áreas do conhecimento sociológico, em contraste, a crítica às teses centrais de um sistema teórico não requer do crítico qualquer tipo de investigação especializada, muito menos algum tipo de investigação verticalizada como a que Westerholm teve que fazer. A razão é simples: quando uma área de estudos se fragmenta em escolas estanques de pensamento, cada estudioso só investiga os problemas que são postos por sua própria área. Nesse caso, a crítica de um ”teórico" de uma "escola” a um "teórico" de "outra escola” não requer do crítico qualquer investigação empírica original. Considere-se, por exemplo, essa crítica de Giddens (figura-chave da teoria da "modernidade reflexiva") a Wallerstein (figura-chave da "teoria do sistema mundial”):

Wallerstein consegue desvencilhar-se de algumas das limitações do pensamento sociológico mais ortodoxo, principalmente da tendência enfaticamente definida a enfocar "modelos endógenos" de mudança social. Mas sua obra tem suas próprias deficiências. Ele continua a ver apenas um nexo institucional dominante (capitalismo) como responsável pelas transformações modernas. A teoria do sistema mundial se concentra, portanto, enfaticamente sobre influências econômicas e considera difícil explicar, de forma satisfatória, precisamente aqueles fenômenos tornados centrais pelos teóricos das relações internacionais: a ascensão do estado-nação e do sistema de estados-nação. Além disso, as distinções entre centro, semiperiferia e periferia (elas mesmas talvez de valor questionável), baseadas em critérios econômicos, não nos permitem elucidar concentrações de poder político ou militar, que 
não se alinham de maneira exata às diferenciações econômicas (GIDDENS, 1991, p. 74).

Quer essa crítica seja pertinente ou não, Giddens não precisou trazer à consideração qualquer resultado original de pesquisa, não precisou ler um documento sequer para formulá-la ${ }^{5}$. Quando o corpo de conhecimento não é fragmentado, como ocorre na teologia do Novo Testamento, a crítica não pode ser feita dessa forma, mesmo porque, agora, não existe mais "figura-chave” nem "outra escola”.

\section{Considerações Finais}

Em 2009, o erudito alemão Udo Schnelle publicou um tratado sobre o Novo Testamento, o livro Theologie des Neuen Testaments, de mais de mil páginas. O que poderia haver para ser dito de novo sobre o Novo Testamento, em pleno ano de 2009, que pudesse requerer mais de mil páginas? A resposta de Schnelle é a de que o livro de Sanders, quer se concorde ou não com as teses ali defendidas, exigiu que os estudos sobre o Novo Testamento fossem reformulados (SCHNELLE, 2009). Nesse mesmo espírito, nosso já conhecido

5 Um leitor crítico desse trabalho objetou que não foi muito feliz trazer a crítica de Giddens a Wallerstein à consideração porque por meio de sua crítica o que Giddens faz é justamente apresentar um enigma específico, passível de ser descrito nos seguintes termos: "como explicar o funcionamento do sistema mundial, tal como o propõe Wallerstein, de tal forma que permita tornar inteligível a formação do Estado-nacional moderno e do sistema interestatal?" A indagação entre aspas é qualquer coisa exceto um enigma tal como o aqui concebemos. Não surpreende que nenhuma agenda de investigação comum tenha se formado a partir dela. Os termos em que ela está formulada são genéricos demais para permitir isso. Compare com o "enigma de Freud", que poderia ser descrito assim: "por que essa moça tem dormência no braço direito se não há "pinçamento" de nervo nem nada de errado com seu sistema neurológico?” Nota-se que aqui não há referência a qualquer "escola" em particular. O mesmo pode ser dito dos enigmas biológico e teológico, já apresentados ao leitor. Em segundo lugar, o que se busca, nesses casos, é a explicação para algum fenômeno específico (uma dormência onde não deveria haver; o surgimento de um olho sextavado, aonde não deveria surgir etc.) cuja ocorrência desafia todo o conhecimento disponível sobre o assunto, independentemente de "escolas". O caso de Giddens é radicalmente distinto. Em primeiro lugar, Giddens não está fazendo referência a qualquer fenômeno específico cuja ocorrência desafia todo um corpo estabelecido de conhecimento produzido sobre algum tema específico, no caso, a formação do estado nacional. Ele está apenas mostrando os problemas envolvidos em aceitar uma formulação teórica de uma "figura-chave" de uma escola em particular. O simples fato de precisar fazer referência explícita a Wallerstein para descrever o "enigma de Giddens" já é suficiente para mostrar que não se trata de enigma algum, não, pelo menos, no sentido em que o é o enigma teológico: "por que Paulo insistia em pregar que a salvação se dava "pelas obras da Lei' se não havia quem sustentasse que fosse?" 
N. T. Wright, na Introdução ao seu já citado livro What Saint Paul really said, se refere à importância do trabalho de Sanders nos seguintes termos:

É uma medida da conquista de Sanders que estudiosos de Paulo ao redor do mundo agora se refiram à 'Revolução de Sanders'. Mesmo aqueles que são hostis às suas teorias não podem negar que houve uma grande mudança na academia, de forma que muitos livros escritos antes de Sanders, ou de um ponto de partida pré-Sanders, agora parecem ser extremamente datados e muito entediantes - algo que nenhum estudo sobre Paulo deveria ser! De minha parte, mesmo discordando fortemente de Sanders em alguns pontos, e pretendendo ir muito além do que ele em outros, não posso negar que ele se elevou no último quarto de século tanto quanto Schweitzer e Bultmann fizeram na primeira metade. (WRIGHT, 1997, p. 18 - ênfases acrescentadas).

Para encerrar nossa peregrinação pelos elogios hiperbólicos dirigidos a Sanders mundo afora, o primeiro em alemão, o segundo em inglês, vamos reproduzir o que foi dito, agora em francês, pelo já citado teólogo sueco Daniel Marguerat (2011), na Introdução a uma coletânea de artigos sobre pesquisas atuais no campo da teologia Paulina, intitulada Paul, une théologie en construction:

A exegese de Paulo parece hoje uma cidade que um tremor de terra devastou. Agitam-se as pessoas por todas as direções, uns avaliando os estragos, outros verificando o que restou ainda de pé. Cada qual avalia as mudanças ainda por vir, mas ninguém ousa ainda recomeçar, com medo de um novo abalo... O terremoto, nesse caso, foi provocado pelo aparecimento, em 1977, do livro Paul and Palestinian Judaism, de E. P. Sanders. A onda de choque foi tão forte que ganhou, pouco a pouco, os campos mais remotos da exegese Paulina. Não é um exagero falar de um antes e de um depois de Sanders. Em todo caso, a leitura dos trabalhos publicados sobre Paulo nos últimos anos mostra que nenhum pesquisador pode evitar esse debate. (MARGUERAT, 2011, p. 11).

Por mais hiperbólicos que pronunciamentos como esses possam parecer, e talvez o sejam mesmo, dificilmente se pode apontar algum livro de sociologia do qual se possa dizer com seriedade algo remotamente semelhante. Não se conclua daí, entretanto, que esses elogios fazem de Sanders uma "figura chave" de alguma "escola de pensamento", nem, muito menos, que seu livro seja uma "obra paradigmática”, no sentido que Thomas Kuhn consagrou a 
esta expressão há mais de cinquenta anos ao publicar A Estrutura das Revoluções Científicas (1962). Para Kuhn, como sabemos, há ciências que já foram bem-sucedidas, e outras que ainda não o foram, em impor a gerações sucessivas de cientistas e candidatos a cientistas um "paradigma”, isto é, um conjunto-padrão de "enigmas" a serem solucionados e um conjunto-padrão de teorias e de métodos a serem empregados na solução desses "enigmas". Nessa perspectiva, uma obra só pode ser dita "paradigmática” quando, em virtude de suas "realizações sem precedentes", como o diz o próprio Kuhn, desencadeia a geração desses conjuntos-padrão de enigmas, teorias e métodos. A marca do sucesso de um paradigma é ter seus enigmas, teorias e métodos expostos de forma impessoal em um livro-texto. O livro de Sanders, conforme vimos, desencadeou o surgimento de um "enigma” incontornável para todos os que estudam a teologia do Novo Testamento, mas não o estabelecimento de um conjunto-padrão de teorias e métodos a serem empregados em sua solução. Ele não fez, portanto, da teologia do Novo Testamento uma "disciplina paradigmática”, no sentido em que o são a física, a química, a biologia, ou qualquer disciplina científica na qual a socialização do iniciante se dá através de livros-textos.

Isso significa que um corpo de conhecimento não precisa necessariamente ser produzido sob o manto de algum paradigma "universalmente aceito" (como o diria Kuhn) para não se fragmentar em "vertentes teóricas" ou "escolas de pensamento" que mal tomam conhecimento da existência umas das outras. Afinal, tudo o que foi aqui discutido nas seções 1 e 2 aponta para o fato de que essa agenda comum de discussão e de investigação conhecida como a Nova Perspectiva sobre Paulo pôde não só ser produzida como, também, prosperar, sem requerer, como o demandaria a perspectiva de Kuhn, a pré-existência de algo como um "paradigma teológico", no qual gerações sucessivas de teólogos tivessem que ter sido socializados. Por outro lado, o surgimento da Nova Perspectiva também não requereu, como o demandaria a conhecida perspectiva de Merton, um prévio acúmulo de "teorias de médio alcance" que pudesse no momento apropriado ser devidamente aproveitado para a realização de uma grande "síntese teórica". Ciente das limitações dessas perspectivas, Alexander procura avançar em relação a ambas. Para ele, Kuhn teria errado ao atribuir às ciências sociais um caráter "pré-paradigmático"; mais exatamente, ao argumentar que falta à sociologia aquilo que toda ciência digna do nome tem: um paradigma universalmente aceito. $\mathrm{O}$ erro, 
segundo Alexander, estaria em desconhecer que a sociologia tem peculiaridades que a conduzem forçosamente a um quadro de fragmentação em "paradigmas" distintos. Nessa perspectiva, com ou sem o acúmulo de "teorias de médio alcance”, a sociologia jamais poderia ter o caráter paradigmático exibido pelas ciências naturais. Mas, daí, conclui Alexander, não resulta que ela seja uma ciência “pré-paradigmática”; ela é, antes, uma ciência "multiparadigmática”, uma vez que pressupõe a coexistência de vários "paradigmas” sem que nenhum deles tenha que prevalecer sobre os demais.

Essa emenda nos parece sair pior que o soneto. Se a Nova Perspectiva sobre Paulo não pode ser considerada um "paradigma universalmente aceito", à moda de Kuhn, ela muito menos poderia ser considerada, à moda de Alexander, um paradigma em meio a tantos outros, cada qual atento apenas aos seus próprios problemas. Vimos que, pelo menos no que diz respeito aos estudos do Novo Testamento, a teologia não pode ser, de forma alguma, considerada uma disciplina "multiparadigmática". Autores como Sanders e Gaston, Dunn e Ruether, Wright e Westerholm, embora sustentem visões radicalmente distintas, ou até mesmo incompatíveis, sobre o significado teológico, histórico e, mesmo, sociológico das cartas de Paulo, não podem ser vistos como representantes de paradigmas distintos, nem como fundadores ou membros destacados de "escolas de pensamento" sem conexão umas com as outras. As contribuições fundamentais de um Stendhal ou de um Sanders, protagonistas da descrita reviravolta ocorrida nos estudos Paulinos, ou de Rosemary Ruether, a quem devemos a mais que oportuna reflexão a respeito do caráter "superacionista” da teologia cristã, não fazem de qualquer um desses teólogos a "figura-chave", por assim dizer, de alguma "escola de pensamento" ou "sistema teórico", diferentemente do que ocorre na sociologia, em que a contribuição de um Wallerstein faz dele a figura-chave de uma escola e a de um Eisenstadt a figura-chave de outra.

Isso remete diretamente à lição que se tem a extrair da discussão aqui realizada: desde que haja algum enigma específico que imponha aos estudiosos de um tema mais amplo uma agenda comum de discussão e de investigação, como é o caso do enigma sobre o qual aqui nos detivemos, a convergência de esforços em uma mesma direção, requerida para evitar a fragmentação de um corpo de conhecimento em escolas estanques de pensamento, pode prescindir tanto 1) de uma prévia socialização em um mesmo paradigma, quanto 2) da existência de um "núcleo duro” de pressupostos teóricos previamente 
aceitos, quanto 3) da demanda por algum esforço bem-sucedido de síntese do qual tenha resultado algum arcabouço teórico-conceitual mais abrangente capaz de servir de "marco teórico de referência” para a investigação empírica. Muito mais que de sistemas teóricos ou de "teorias de médio alcance”, a unidade disciplinar depende da existência de enigmas desafiadores. Nesse artigo, procuramos reconstruir a história de um desses enigmas e discutir seu efeito unificador.

\section{Referências bibliográficas}

ALEXANDER, Jeffrey. (1987), “O Novo Movimento Teórico”. Revista Brasileira de Ciências Sociais, v. 2, n. 4, pp. 6-29.

DUNN, James. ([1998] 2003), A Teologia do Apóstolo Paulo. São Paulo: Paulus. DUNN, James. ([2007]2011), Nova Perspectiva Sobre Paulo. Grand Rapids (Michigan): Eerdmans Publishing.

DUNN, James. (1983), The New Perspective on Paul. Bulletin of the John Rylands University Library of Manchester, v. 65, pp. 95-122.

GASTON, Lloyd. (1987), Paul and the Torah. Vancouver: University of British Columbia Press.

GIDDENS, Anthony. (1991), As consequências da modernidade. São Paulo: Editora Unesp.

HAGNER, Donald A. ([1993] 2001), Paulo e o judaísmo: testando a nova perspectiva. In: STUHLMACHER, Peter. Lei e graça em Paulo: uma resposta à polêmica em torno da doutrina da justificação. São Paulo: Vida Nova.

KEENER, Criag S. (2005), Comentário Bíblico Atos - Novo Testamento. Belo Horizonte: Ed. Atos.

KUHN, Thomas. (1962), The Structure of Scientific Revolutions. Chicago: The University of Chicago Press.

LUTERO, Martinho. ([1531] 2008), Interpretação do Novo Testamento Gálatas - Tito. São Leopoldo: Editora Sinodal.

MARGUERAT, Daniel. ([2004] 2011), Introdução. In: DETTWILER, Andreas; ALETTI, Jean Noël; KAESTLI, Jean-Daniel; MARGUERAT, Daniel. Paulo, uma teologia em construção. São Paulo: Edições Loyola.

MERTON, Robert. ([1949]1968), Sociologia. Teoria e Estrutura. São Paulo: Mestre Jou Editora.

RUETHER, Rosemary. (1974), Faith and Fratricide. The Theological Roots of Anti-Semitism. Minneapolis: The Seabury Press. 
SANDERS, E. P., (1977) Paul and Palestinian Judaism: A Comparison of Patterns of Religion. Philadelphia: Fortress Press.

SCHENELLE, Udo. (2009), Theology of the new testament. Grand Rapids: Baker Publishing Group.

STENDHAL, Krister, (1963), "The Apostle Paul and the Introspective Conscience of the West”. Harvard Theologiocal Review, v. 56, pp. 199-215.

WESTERHOLM, Stephen, (2003), Perspective old and new on Paul: the "Lutherean"Paul and his critics. Grand Rapids: Wm. B. Eerdmans Publishing Company.

WRIGHT, Nicholas T. (2013), Paul and the faithfulness of god. London: Fortress Press Edition.

WRIGHT, Nicholas T. (1997), What Saint Paul really said: was Paul of Tarsus the real founder of Christianity. Grand Rapids: Eerdmans Publishing Company. 


\section{Diretrizes para Submissão de Artigos}

\section{Normas para submissão de artigos à Revista Brasileira de Sociologia}

A Revista Brasileira de Sociologia - RBS publica artigos em Ciências Sociais, preferencialmente em Sociologia. Os textos devem refletir a produção acadêmica e cientifica acerca da realidade brasileira e mundial contemporâneas. As matérias veiculadas na Revista deverão incluir artigos de natureza acadêmica e didática, registrando eventuais reedição de textos clássicos, literatura comentada sobre assuntos variados, textos de metodologia e reflexão sobre conceitos ou autores, hoje imprescindíveis ao profissional do ensino médio e superior.

A Revista é quadrimestral e aceita proposta de Dossiês, mediante Editais Públicos.

Artigos com temáticas diversificadas na área da RBS podem ser submetidos a qualquer data e em caráter de fluxo contínuo, através do e-mail rbsfluxo@gmail.

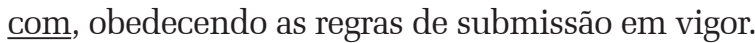

Considerando a desejada manutenção do alto padrão de qualidade e especialidade do periódico, todos os artigos a serem publicados são avaliados pelo sistema de pares (avaliação às cegas).

O envio espontâneo de qualquer colaboração implica automaticamente a cessão integral dos direitos autorais à RBS. 


\section{Condições para submissão}

Os artigos submetidos devem ser inéditos e devem assim permanecer durante a avaliação.

Como parte do processo de submissão, os autores são obrigados a verificar a conformidade da submissão em relação a todos os itens listados a seguir. As submissões que não estiverem de acordo com as normas serão devolvidas aos autores.

Os artigos não devem ultrapassar 50 mil caracteres com espaço, incluindo a bibliografia. O artigo deve ter resumo de 900 caracteres com espaço e 3 (três) palavras-chaves. Deve acompanhar, em arquivo separado, Nome completo do(s) autores(s), titulação, vinculo institucional, endereço.

Propostas de Dossiês devem ser enviadas com a apresentação da temática, sua relevância e abrangência para o campo dos estudos sociológicos. A proposta deve vir acompanhada dos dados dos proponentes: nome completo do(s) autores(s), titulação, vinculo institucional, endereço.

Os artigos submetidos devem conter resumo, titulo do artigo, e palavras-chaves em português e inglês.

As remissões bibliográficas no corpo do texto ou referências após citações a autores, devem seguir a forma (Autor, data) ou (Autor, data, página), como nos exemplos: (MILLS, 1960) ou (BENJAMIM, 1987,p. 205). Se houver mais de um título do mesmo autor no mesmo ano, eles são diferenciados por uma letra após a data: SIMMEL, 1965a), (SIMMEL, 1965b) etc.

A RBS apoia os esforços relativos à visibilidade das mulheres na produção acadêmica. Assim, as referências bibliográficas ao final do artigo devem conter o prenome das autoras e dos autores, não apenas suas iniciais, como se segue: 


\section{Referências bibliográficas:}

Livros:

LI, Peilin; SCALON, Celi; GORSHOKOV, Mikhail K.; SHARMA, Kumar (2013), Handbook on Social Stratification in the BRIC Countries: Change and Perspective. 1. ed. Cingapura/ Londres/New Jersey: World Scientific.

\section{Artigos:}

TOLBERT, Pamela S. (1986), “Organizations and inequality: Sources of earnings differences between male and female faculty". American Sociological Review n. 59, pp. 227-235.

Coletâneas:

INGRAM, Helen; SCHNEIDER, Anne I.; DELEON, Peter. (2007), "Social construction and policy design”. In: SABATIER, Paul A. (org.). Theories of the policy process. Cambridge, MA: Westview Press.

Teses Acadêmicas:

FORTUNA, Carlos. (1988), Threading Through: Cotton Production, Colonial Mozambique and Semiperipheral Portugal in the World-Economy. Tese de Doutorado. State University of New York - Binghamton. 